\title{
VERIFICATION SURVEY OF BUILDING 200 HOT CELLS
}

RECEIVED

JUN 18 1996

OSTI

by

C. M. Sholeen

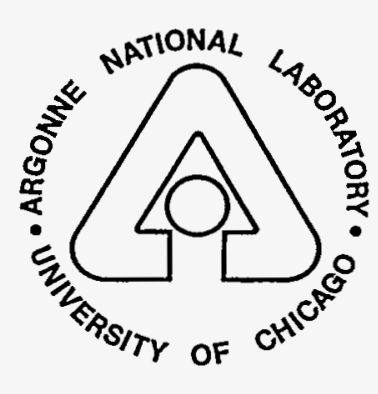

ARGONNE NATIONAL LABORATORY, ARGONNE, ILLINOIS

Operated by THE UNIVERSITY OF CHICAGO

for the U.S. DEPARTMENT OF ENERGY

under Contract W-31-109-Eng-38

DISTRIBUTION OF THIS DOCUMENT I8 UNAMHED औT 
Argonne National Laboratory, with facilities in the states of Illinois and Idaho, is owned by the United States government, and operated by The University of Chicago under the provisions of a contract with the Department of Energy.

\section{DISCLAIMER}

This report was prepared as an account of work sponsored by an agency of the United States Government. Neither the United States Government nor any agency thereof, nor any of their employees, makes any warranty, express or implied, or assumes any legal liability or responsibility for the accuracy, completeness, or usefulness of any information, apparatus, product, or process disclosed, or represents that its use would not infringe privately owned rights. Reference herein to any specific commercial product, process, or service by trade name, trademark, manufacturer, or otherwise, does not necessarily constitute or imply its endorsement, recommendation, or favoring by the United States Government or any agency thereof. The views and opinions of authors expressed herein do not necessarily state or reflect those of the United States Government or any agency thereof. 


\title{
VERIFICATION SURVEY OF BUILDING 200 HOT CELLS
}

\section{ARGONNE NATIONAL LABORATORY ARGONNE, ILLINOIS}

\author{
Prepared by \\ C. M. Sholeen \\ Environment Safety and Health Division \\ Health Physics Section \\ Argonne National Laboratory \\ Argonne, IL 60439
}

March 1996 


\section{EXECUTIVE SUMMARY}

At the start of this D\&D project, the decontamination goals were set at 1) reducing the stack emissions to $10 \%$ of the 1991 emissions; 2) reducing the exposure rate in each cell to $<1$ $\mathrm{mR} / \mathrm{h}$; and 3 ) reducing the removable contamination to none detectable. Since the contamination can be fixed with paint, the other two goals were given priority. The estimate of the 1995 emissions from K-3 was $20 \%$ of the 1991 emissions estimate. However, the 1996 estimates are 9\% of the 1991 emissions estimate. Since in 1991 the K-3 emissions were only $1 / 2 \%$ of the emissions from $M-1$, even the $20 \%$ reduction has little effect on the project reduction. The total emissions have been reduce to $\sim 2 \frac{1}{4} \%$ of the 1991 emissions from the 5 hot cells that were decontaminated. The emissions and exposure rates are presented in Table i below. Cells A-1 and $\mathrm{M}-1$ exceed the exposure rate criteria. For the other cells, the general exposure rate in the middle of the cell meets the criteria. However, near the prefilters, the exposure rates increase. Cell M-1 has extensive floor contamination that penetrated to a 6 inch depth. At $30 \mathrm{~cm}$ above the floor, the exposure rate through the lead blanket is $50 \mathrm{mR} / \mathrm{h}$. A more detailed list of acceptance criteria were specified before the final verification survey. Table ii compares the maximum survey results on the wall or floor surface of each cell to these criteria. Cells M-1 and A-1 frequently fail to meet these criteria.

Table i. General Hot Cell Exposure Rates and Emissions

\begin{tabular}{||c|c|c|c|c||c|c||}
\hline \multirow{2}{*}{ Cell } & \multicolumn{2}{|c|}{$\mathrm{mR} / \mathrm{h}$} & \multicolumn{2}{c|}{$\mathrm{mR} / \mathrm{h} @ 30 \mathrm{~cm}$} & \multicolumn{2}{c||}{$\% 1991$ Emissions } \\
\cline { 2 - 7 } & Criteria & $\begin{array}{c}\text { General } \\
@ 13 / 4 \mathrm{~m}\end{array}$ & $\begin{array}{c}\text { High Flow } \\
\text { Filter }\end{array}$ & $\begin{array}{c}\text { Low Flow } \\
\text { Filter }\end{array}$ & Criteria & Current \\
\hline $\mathrm{A}-1$ & $\leq 1.0$ & $\mathbf{2 . 5}$ & $\mathbf{2 . 0}$ & $\mathbf{2 . 0}$ & $<10$ & $\mathrm{NA}$ \\
\hline $\mathrm{K}-1$ & $\leq 1.0$ & 0.5 & 0.5 & $\mathbf{2 . 0}$ & $<10$ & 0.8 \\
\hline $\mathrm{K}-3$ & $\leq 1.0$ & 0.2 & 0.2 & 0.1 & $<10$ & $\sim 9$ \\
\hline $\mathrm{M}-3$ & $\leq 1.0$ & 0.2 & 0.1 & $\mathbf{2 . 0}$ & $<10$ & 6 \\
\hline $\mathrm{M}-1$ & $\leq 1.0$ & $\mathbf{5 . 0}$ & $\mathbf{1 0}$ & $\mathbf{5 , 0}$ & $<10$ & 3 \\
\hline $\mathrm{M}-1$ cell center & $\mathbf{1 0}$ & & & & \\
\hline
\end{tabular}

The highlighted bolded valies are above the cléanup criteria 


\begin{tabular}{|c|c|c|c|c|c|c|c|}
\hline Survey Type (units) & West Wall & North Wall & East Wall & South Wall & Floor & 'Overhead & Criteria \\
\hline \multicolumn{8}{|c|}{ Cell A-1 } \\
\hline${ }^{b}$ Direct $\gamma(\mathrm{mR} / \mathrm{h})$ & $1.30 \%$ & $7.720 \%$ & 1.0 & 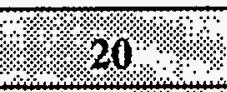 & 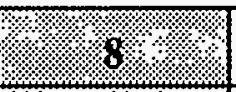 & dNA & ${ }^{5} 5$ or 50 \\
\hline Direct $\alpha\left(\mathrm{dpm} / 61 \mathrm{~cm}^{2}\right)$ & $1 \% 1 \mathrm{M} \div$ & $5001 \%$ & (100k & $11 \mathrm{n}$ & $1.91 \%$ & NA & $3 k$ \\
\hline${ }^{\mathrm{B}} \mathrm{S}$ mear $\alpha / \beta\left(\mathrm{dpm} / 1 \mathrm{~m}^{2}\right)$ & $12 \mathrm{k} / 510 \mathrm{k}$ & $3.9 \mathrm{k} / 120 \mathrm{k}$ & $630 / 35 \mathrm{k}$ & $14 \mathrm{k} / 180 \mathrm{k}$ & $15 \mathrm{k} / 440 \mathrm{k}$ & NA & $20 \mathrm{k} / 1 \mathrm{M}$ \\
\hline${ }^{\mathrm{h}} \mathrm{S}$ ear $\alpha / \beta\left(\mathrm{dpm} / 100 \mathrm{~cm}^{2}\right)$ & $520 / 12 \mathrm{k}$ & $0.4 k 1600 k$ & $180 / 9 \mathrm{k}$ & $520 / 15 \mathrm{k}$ & 1.16724 & NA & $800 / 50 \mathrm{k}$ \\
\hline \multicolumn{8}{|c|}{ Cell K-1 } \\
\hline Direct $\gamma(\mathrm{mR} / \mathrm{h})$ & 0.5 & 10 & 25.1 & 10 & 4 & 0.1 & 5 or 50 \\
\hline Direct $\alpha\left(\mathrm{dpm} / 61 \mathrm{~cm}^{2}\right)$ & $60 \mathrm{k}$ & 2.6001 & 2000 & $480 \mathrm{k} \%$ & $>>1 \mathrm{M}$ & $30 \mathrm{k} \div$ & $3 \mathrm{k}$ \\
\hline Smears $\alpha / \beta\left(\mathrm{dpm} / 1 \mathrm{~m}^{2}\right)$ & $3.4 \mathrm{k} / 190 \mathrm{k}$ & $2.3 \mathrm{k} / 82 \mathrm{k}$ & $730 / 78 \mathrm{k}$ & $3.5 \mathrm{k} / 180 \mathrm{k}$ & $4.7 \mathrm{k} / 600 \mathrm{k}$ & $9.3 \mathrm{k} / 320 \mathrm{k}$ & $20 \mathrm{k} / 1 \mathrm{M}$ \\
\hline Smears $\alpha / \beta\left(\mathrm{dpm} / 100 \mathrm{~cm}^{2}\right)$ & $55 / 2 \mathrm{k}$ & $430 / 13 k$ & $320 / 3.6 \mathrm{k}$ & $300 / 7 \mathrm{k}$ & $1.7 \mathrm{k110}$ & NA & $800 / 50 \mathrm{k}$ \\
\hline \multicolumn{8}{|c|}{ Cell K-3 } \\
\hline Direct $\gamma(\mathrm{mR} / \mathrm{h})$ & 0.5 & 0.5 & 0.7 & 0.4 & 0.1 & 0.1 & 5 or 50 \\
\hline Direct $\alpha\left(\mathrm{dpm} / 61 \mathrm{~cm}^{2}\right)$ & $\%+50 \mathrm{k}$ & $4.901 \%$ & $8.901 \%$ & (.) $9 \mathrm{k}$ ? & ?: $201 \%$ & 5018 & $3 \mathrm{k}$ \\
\hline Smears $\alpha / \beta\left(\mathrm{dpm} / 1 \mathrm{~m}^{2}\right)$ & $110 / 4.6 \mathrm{k}$ & $430 / 5.2 \mathrm{k}$ & $200 / 5.9 \mathrm{k}$ & $480 / 7.1 \mathrm{k}$ & $440 / 16 \mathrm{k}$ & NA & $20 \mathrm{k} / 1 \mathrm{M}$ \\
\hline Smears $\alpha / \beta\left(\mathrm{dpm} / 100 \mathrm{~cm}^{2}\right)$ & $50 / 1.4 \mathrm{k}$ & $70 / 560$ & $90 / 540$ & $260 / 1.2 \mathrm{k}$ & $90 / 2.5 \mathrm{k}$ & NA & $800 / 50 \mathrm{k}$ \\
\hline
\end{tabular}


iii

\begin{tabular}{|c|c|c|c|c|c|c|c|}
\hline Survey Type (units) & West Wall & North Wall & East Wall & South Wall & Floor & Overhead & Criteria \\
\hline \multicolumn{8}{|c|}{ Cell M-3 } \\
\hline Direct $\gamma(\mathrm{mR} / \mathrm{h})$ & 3.0 & 10 & 0.5 & 3.0 & 2.0 & 0.1 & 5 or 50 \\
\hline Direct $\alpha\left(\mathrm{dpm} / 61 \mathrm{~cm}^{2}\right)$ & $6 \mathrm{k}$ & $1 \% 30 \mathrm{k}$ & $20 \mathrm{k}$ & $\therefore 50 k$ & $40 \mathrm{k}$ & $\sqrt{3} 4 \%$ & $3 \mathrm{k}$ \\
\hline Smears $\alpha / \beta\left(\mathrm{dpm} / 1 \mathrm{~m}^{2}\right)$ & $220 / 33 k$ & $120 / 19 \mathrm{k}$ & $86 / 5.7 \mathrm{k}$ & $490 / 32 \mathrm{k}$ & $210 / 19 \mathrm{k}$ & $3.2 \mathrm{k} / 460 \mathrm{k}$ & $20 \mathrm{k} / 1 \mathrm{M}$ \\
\hline Smears $\alpha / \beta\left(\mathrm{dpm} / 100 \mathrm{~cm}^{2}\right)$ & $55 / 1.4 \mathrm{k}$ & $290 / 1.4 \mathrm{k}$ & $71 / 4.5 \mathrm{k}$ & $48 / 2.8 \mathrm{k}$ & $300 / 32 \mathrm{k}$ & NA & $800 / 50 \mathrm{k}$ \\
\hline \multicolumn{8}{|c|}{ Cell M-1 } \\
\hline Direct $\gamma(\mathrm{mR} / \mathrm{h})$ & 828 & 45 & 10 & 20 & $\% 1000$ & 50 & 5 or 50 \\
\hline Direct $\alpha\left(\mathrm{dpm} / 61 \mathrm{~cm}^{2}\right)$ & $500 \mathrm{k}$ & $18>10$ & १५M & $700 \mathrm{k}$ & $\checkmark 1 \mathrm{M}$ & $600 \mathrm{k}$ & $3 \mathrm{k}$ \\
\hline Smears $\alpha / \beta\left(\mathrm{dpm} / 1 \mathrm{~m}^{2}\right)$ & $900 / 81 \mathrm{k}$ & $.6 \%+4.3 \mathrm{M}$ & $20 \mathrm{k} .680 \mathrm{k}$ & $1 \mathrm{k} / 71 \mathrm{k}$ & $57 \mathrm{k} / 1.5 \mathrm{M}$ & NA & $20 \mathrm{k} / 1 \mathrm{M}$ \\
\hline
\end{tabular}

"Overhead usually refers to the crane, not the ceiling

${ }^{b}$ Direct $\gamma(\mathrm{mR} / \mathrm{h})=$ Direct $\gamma$ Survey with an RO-20 Ion Chamber with the $\beta$ shield closed; Bkgd $=0.1$

c The highilighted bolded yalies are above the acceptance goals.

$\mathrm{NA}=$ Not Available; survey was not performed

- Direct $\gamma$ Criteria $5 \mathrm{mR} / \mathrm{h}$ general; $50 \mathrm{mR} / \mathrm{h}$ Exhaust Ducts and HEPA filter housing (see Table 1)

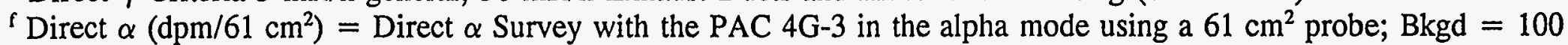

${ }^{\text {B }}$ Smears $\alpha / \beta\left(\mathrm{dpm} / 1 \mathrm{~m}^{2}\right)=$ Large Area Smears $\left(1 \mathrm{~m}^{2}\right)$ given as $\alpha / \beta$; Bkgd $=0 / 0$

${ }^{\mathrm{h}}$ Smears $\alpha / \beta\left(\mathrm{dpm} / 100 \mathrm{~cm}^{2}\right)=$ Small Area Smears $\left(100 \mathrm{~cm}^{2}\right)$ given as $\alpha / \beta$; Bkgd $=0 / 0$ 


\section{ACKNOWLEDGEMENTS}

The remote work and initial cell entries were performed by CMT and RE personnel with the support of HP and EWM personnel. The final decontamination of cells A-1, K-1 and K-3 were performed by CMT and RE personnel. The final decontamination of cells $\mathrm{M}-3$ and $\mathrm{M}-1$ were performed by EWM personnel. The verification surveys were performed by HP personnel. Individual contributions are indicated by their names.

\section{CHEMICAL TECHNOLOGY (CMT) STAFF}

J. C. Hoh - Technical Support Manager L. D. Hafenrichter (repair manipulators)
T. DiSanto
R. Benson
J. W. Emery
M. Goss
M. Surchik
H. Wegerich

REACTOR ENGINEERING (RE) STAFF

J. K. Dunlap

R. H. Gebner - Assistant Technical Support Manager

\section{HEALTH PHYSICS (HP) STAFF}

D. C. Geraghty - Chief Technician

C. M. Sholeen - Health Physicist

N. L. Contos (generate cell maps)

A. L. Keebler (generate cell maps)

D. W. Reilly (generate cell maps)

T. Branch

F. P. Marchetti (calibrate stack monitors)

M. R. O'Connor

J. Erick

M. A. Sreniawski

M. E. Hayes

R. Walker

C. Sullivan (word processing)

ENVIRONMENT AND WASTE MANAGEMENT (EWM) STAFF

T. J. Lahey - Foreman

W. D. Ray - Foreman

E. E. Armond

K. Borman

M. L. Davis

J. J. Gleason

G. A. Harris

D. E. Kuzma

G. L. Redman

J. J. Smeets

C. E. Wood

\section{ELECTRONICS AND COMPUTING TECHNOLOGIES (ECT) STAFF}

Designed, built, and maintained the stack monitoring system.

R. W. Fergus

J. E. Miranda, Jr

ENVIRONMENT SAFETY AND HEALTH (ESH) STAFF

D. M. Nelson (Cell K-3 alpha spectrum interpretation)

E. H. Dolecek (dosimetry)

R. R. Gustafson

D. R. Pepalis

TECHNOLOGY DEVELOPMENT (TD) STAFF

C. L. Cheever - First Project Manager R. W. Rose - Second Project Manager

W. E. Stacy - Project Engineer 


\section{TABLE OF CONTENTS}

Title

Page

EXECUTIVE SUMMARY $\ldots \ldots \ldots \ldots \ldots \ldots \ldots \ldots \ldots \ldots \ldots$ i

ACKNOWLEDGEMENTS $\ldots \ldots \ldots \ldots \ldots \ldots \ldots \ldots \ldots$ iv

LIST OF FIGURES $\ldots \ldots \ldots \ldots \ldots \ldots \ldots \ldots \ldots \ldots \ldots \ldots \ldots \ldots \ldots \ldots$

LIST OF TABLES $\ldots \ldots \ldots \ldots \ldots \ldots \ldots \ldots \ldots \ldots \ldots \ldots \ldots \ldots$ xii

ABBREVIATIONS AND ACRONYMS $\ldots \ldots \ldots \ldots \ldots \ldots \ldots \ldots$ xiv

I. HISTORY . . . . . . . . . . . . . . . . . . . . 1

A. Description of the Shielded Cave Complex . . . . . . . . . . 1

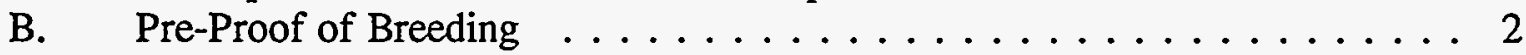

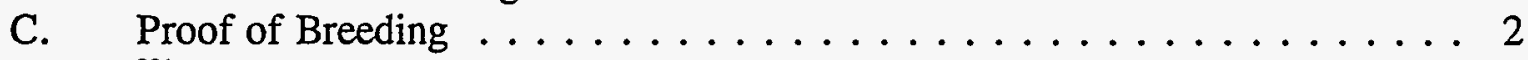

D. $\quad{ }^{231} \mathrm{~Pa}$ work in Cell $\mathrm{K}-3 \ldots \ldots \ldots \ldots \ldots \ldots \ldots$

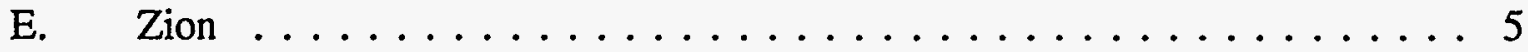

II. FINAL SURVEY PROCEDURES $\ldots \ldots \ldots \ldots \ldots \ldots \ldots \ldots \ldots$

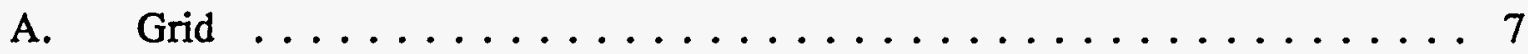

B. Acceptance Goals . . . . . . . . . . . . . . 7

C. Direct $\alpha$ Survey . . . . . . . . . . . . . . 7

D. Direct $\gamma$ Survey . . . . . . . . . . . . . . . . 8

E. Large Area Smears and Small Area Smears $\ldots \ldots \ldots \ldots \ldots$

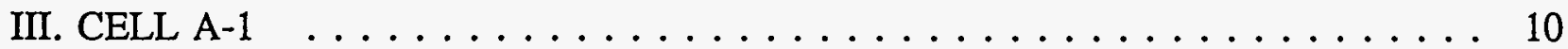

A. INITIAL CELL CONDITION $\ldots \ldots \ldots \ldots \ldots \ldots \ldots \ldots$

1. Spills and Contamination $\ldots \ldots \ldots \ldots \ldots \ldots \ldots \ldots$

2. Stack Emissions . . . . . . . . . . . . . . . 10

B. DECONTAMINATION $\ldots \ldots \ldots \ldots \ldots \ldots \ldots \ldots \ldots \ldots$

1. Waste Removed .................... 10

2. Accumulated Dose .................. 11

3. Decontamination Limit . . . . . . . . . . . . . . 11

C. FINAL SURVEY RESULTS $\ldots \ldots \ldots \ldots \ldots \ldots \ldots \ldots \ldots \ldots$

1. A-1 West Wall . . . . . . . . . . . . 12

2. A-1 North Wall .................. 13

3. A-1 East Wall and Door $\ldots \ldots \ldots \ldots \ldots \ldots \ldots$

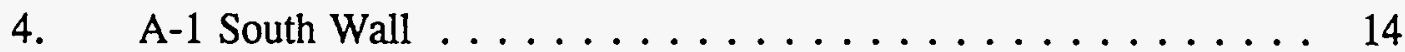

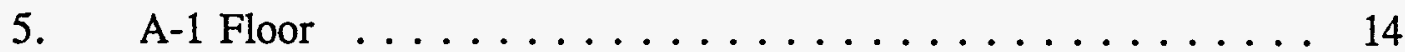

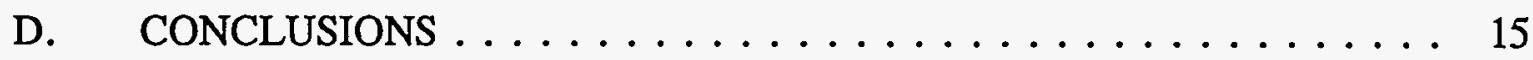


Verification Survey of Building 200 Hot Cells March 1996 vi

TABLE OF CONTENTS continued

Title

1. Measurements of Residual Radon Gas . . . . . . . . . . . . 15

2. Cell Decontamination Summary ................ 16

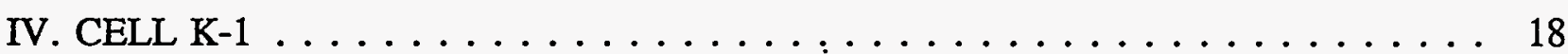

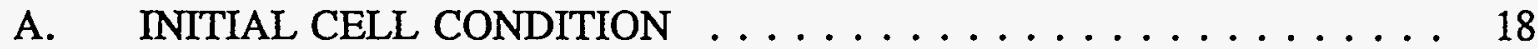

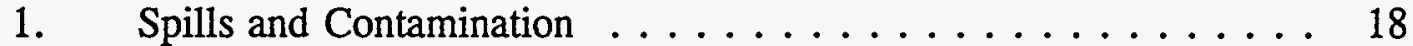

2. Stack Emissions ..................... 18

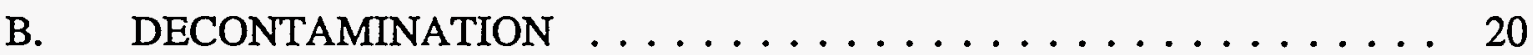

1. Waste Removed ..................... 20

3. Decontamination Limit . . . . . . . . . . . . . . 20

C. FINAL SURVEY RESULTS ...................... 20

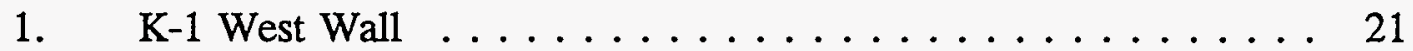

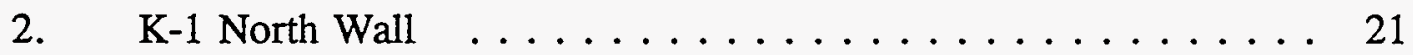

3. K-1 East Wall ........................ 22

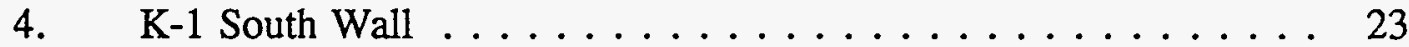

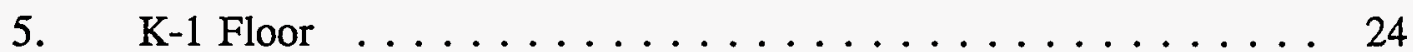

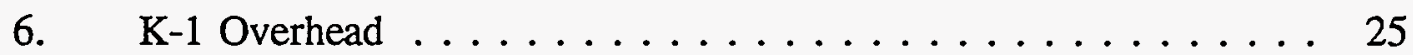

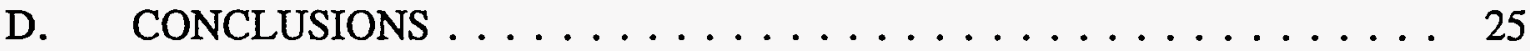

1. Measurements of Residual Radon Gas ............. 25

2. Cell Decontamination Summary ............... 26

3. Stack Emissions .................... 27

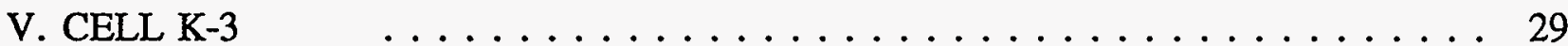

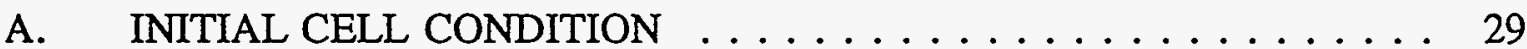

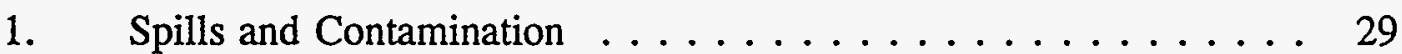

2. Stack Emissions ...................... 29

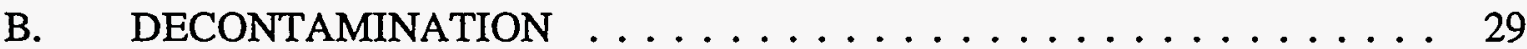

1. Waste Removed ..................... . . 29

2. Accumulated Dose .................... 31

3. Decontamination Limit . . . ............... 31

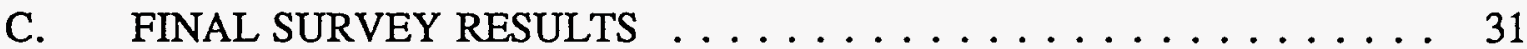

1. $\mathrm{K}-3$ West Wall $\ldots \ldots \ldots \ldots \ldots \ldots \ldots \ldots \ldots \ldots$

2. $\mathrm{K}-3$ North Wall $\ldots \ldots \ldots \ldots \ldots \ldots \ldots \ldots$

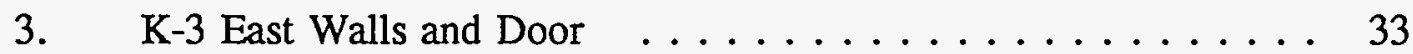

4. K-3 South Wall .................... 33

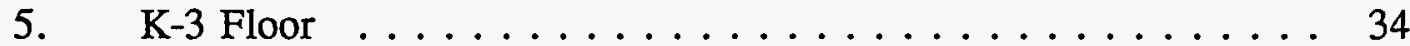

6. $\mathrm{K}-3$ Overhead $\ldots \ldots \ldots \ldots \ldots \ldots \ldots \ldots$

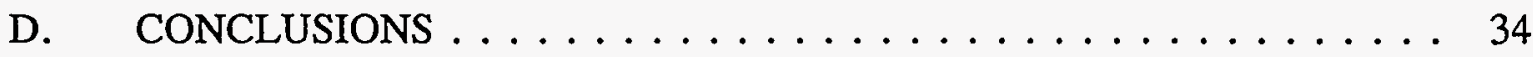

1. Measurements of Residual Radon Gas ... . . . . . . . . . 34

2. Cell Decontamination Summary ............... 36 
Verification Survey of Building 200 Hot Cells March 1996 vii

TABLE OF CONTENTS continued

Title

3. Stack Emissions $\ldots \ldots \ldots \ldots \ldots$

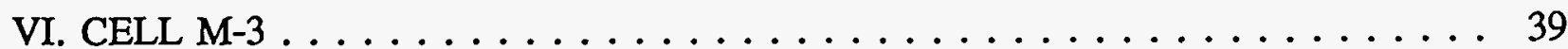

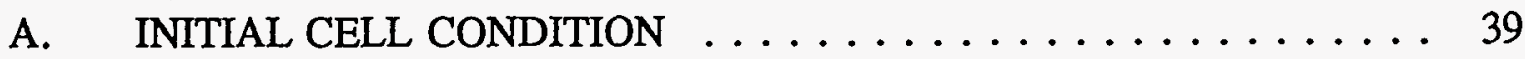

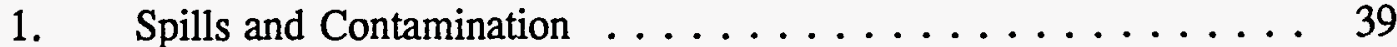

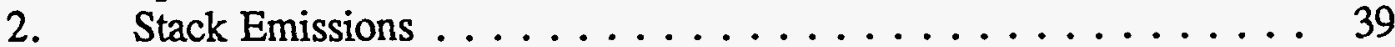

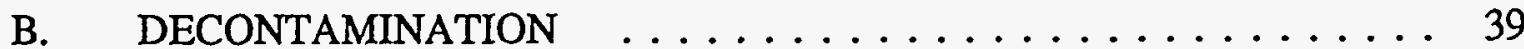

1. Waste Removed ....................... 39

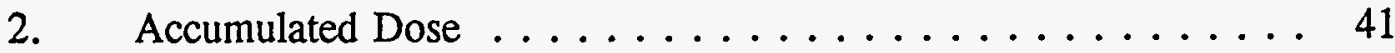

3. Decontamination Limit . . . . . . . . . . . . . . . 41

C. FINAL SURVEY RESULTS ................... 42

1. M-3 West Wall ... . . . . . . . . . . . . . . 42

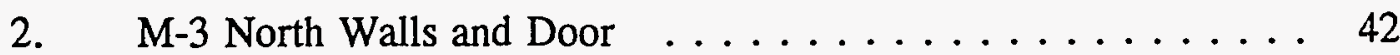

3. M-3 East Wall ..................... 43

4. M-3 South Wall ... . . . . . . . . . . . . . . . 44

5. $\mathrm{M}-3$ Floor $\ldots \ldots \ldots \ldots \ldots \ldots \ldots \ldots$

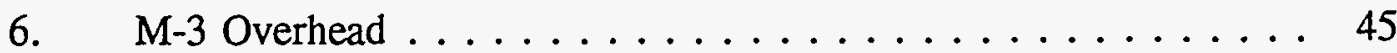

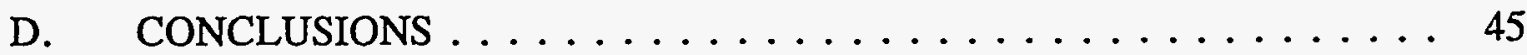

1. Measurements of Residual Radon Gas ... . . . . . . . . . 45

2. Cell Decontamination Summary ... . . . . . . . . . . . 46

3. Stack Emissions ... . . . . . . . . . . . . . . 47

VII. Cell $\mathrm{M}-1 \ldots \ldots \ldots \ldots \ldots \ldots \ldots \ldots \ldots \ldots \ldots$

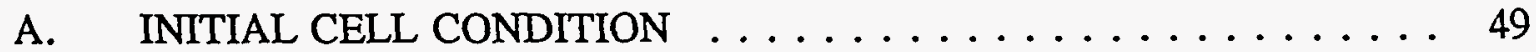

1. Spills and Contamination .................. 49

2. Stack Emissions ... . . . . . . . . . . . . . . . . . . . . . . . . . . . 49

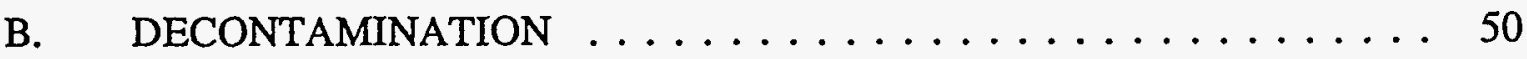

1. Waste Removed ... . . . . . . . . . . . . . . . 50

2. Accumulated Dose .................... 52

3. Decontamination Limit . . . . . . . . . . . . . . 52

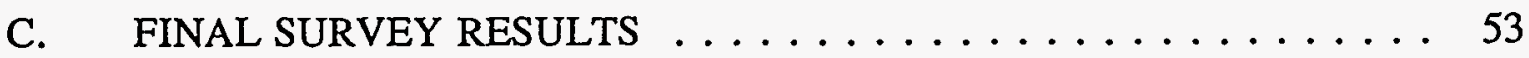

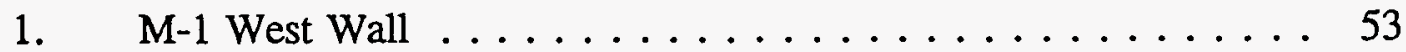

2. M-1 North Wall ................... 54

3. M-1 East Wall ...................... 54

4. M-1 South Walls and Door ............... 55

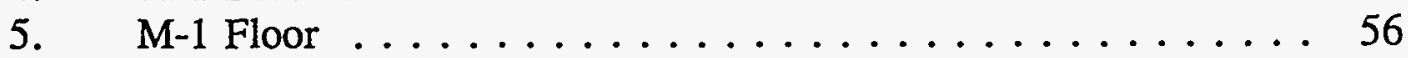

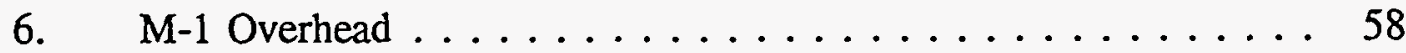

7. M-1 North Wall Outside the Cell ... . . . . . . . . . . 58

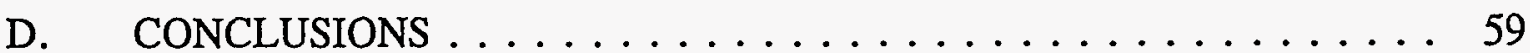

1. Measurements of Residual Radon Gas ... . . . . . . . . . 59 
Verification Survey of Building 200 Hot Cells

March 1996 viii

TABLE OF CONTENTS continued

Title

Page

2. Cell Decontamination Summary ... . . . . . . . . . . 59

3. Stack Emissions .................... 61

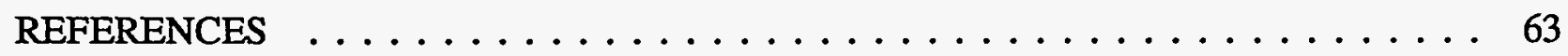

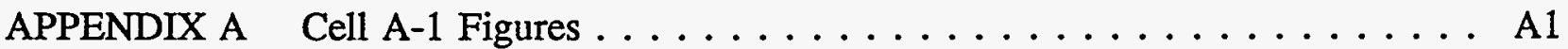

APPENDIX B Cell $\mathrm{K}-1$ Figures $\ldots \ldots \ldots \ldots \ldots \ldots \ldots \ldots \ldots$

APPENDIX $\mathrm{C}$ Cell $\mathrm{K}-3$ Figures $\ldots \ldots \ldots \ldots \ldots \ldots \ldots \ldots \ldots$

APPENDIX D Cell M-3 Figures $\ldots \ldots \ldots \ldots \ldots \ldots \ldots \ldots \ldots \ldots \ldots$

APPENDIX E Cell M-1 Figures $\ldots \ldots \ldots \ldots \ldots \ldots \ldots \ldots \ldots \ldots$ 


\section{LIST OF FIGURES}

No. Title Page

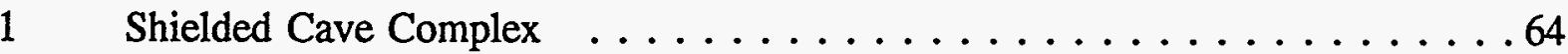

2 Fissionable ${ }^{233} \mathrm{U}$ from ${ }^{232} \mathrm{Th} ;{ }^{238} \mathrm{U} \&{ }^{239} \mathrm{Pu} /{ }^{235} \mathrm{U}$ Decay $\ldots \ldots \ldots \ldots \ldots 65$

3 Decay of Radon, Thoron \& Actinon . . . . . . . . . . . . . 66 66

4 Alpha Spectrum from Radon Gas in Clean Area . . . . . . . . . . . . 67

5 Alpha-6 Rn \& Tn Activities in Clean Area . . . . . . . . . . . .667

6 Contributions to the Dose $\ldots \ldots \ldots \ldots \ldots \ldots$

$7 \quad$ TLD Badge Deep Doses $\ldots \ldots \ldots \ldots$. . . . . . . . . . . . . . . . . . .

$8 \quad$ TLD Badge Shallow Doses $\ldots \ldots \ldots \ldots$. . . . . . . . . . . . 69

9 TLD Ring Doses . . . . . . . . . . . . . . . . . . . . . . .69

10 Quarterly ${ }^{220} \mathrm{Rn}$ Emissions from Cell K-1; 1984 to $1996 \ldots \ldots \ldots$. . . . . . 70

11 Quarterly ${ }^{220} \mathrm{Rn}$ Emissions from Cell K-1; 1988 to 1996 . . . . . . . . . . . 70

12 Emissions from Building 200 Stacks . . . . . . . . . . . . . . 71

13 Quarterly ${ }^{220} \mathrm{Rn}$ Emissions from Cell $\mathrm{K}-3 \ldots \ldots \ldots \ldots \ldots \ldots 72$

14 Quarterly ${ }^{220} \mathrm{Rn}$ Emissions from Cell M-3 . . . . . . . . . . . . . 72

15 Quarterly ${ }^{220} \mathrm{Rn}$ Emissions from Cell M-1; 1984 to 1996 . . . . . . . . . 73

16 Quarterly ${ }^{220} \mathrm{Rn}$ Emissions from Cell M-1; 1987 to 1996 . . . . . . . . . 73

A-1 Building 200 Wing $M-$ Cell $A-1 \ldots \ldots \ldots \ldots \ldots \ldots \ldots \ldots \ldots$

A-2 Building 200 Wing $M$ - Cell A-1 West Wall; RO-20 . . . . . . . A3

A-3 Building 200 Wing $M$ - Cell A-1 West Wall; PAC . . . . . . . . A A4

A-4 Building 200 Wing $M$ - Cell $A-1$ West Wall; Smear $1 \mathrm{~m}^{2} \ldots \ldots \ldots \ldots$ A5

A-5 Building 200 Wing $M$ - Cell A-1 West Wall; Smear $100 \mathrm{~cm}^{2} \ldots \ldots \ldots$ A6

A-6 Building 200 Wing $M$ - Cell A-1 North Wall; RO-20 . . . . . . . . . A7

A-7 Building 200 Wing $M$ - Cell A-1 North Wall; PAC . . . . . . . . . A8

A-8 Building 200 Wing $M$ - Cell A-1 North Wall; Smear $1 \mathrm{~m}^{2} \ldots \ldots \ldots$. . A 9

A-9 Building 200 Wing $M$ - Cell A-1 North Wall; Smear $100 \mathrm{~cm}^{2} \ldots \ldots$. . A A10

A-10 Building 200 Wing $M$ - Cell A-1 East Wall and Door; RO-20 . . . . . . . A11

A-11 Building 200 Wing $M$ - Cell A-1 East Wall and Door; PAC . . . . . . . A12

A-12 Building 200 Wing $M$ - Cell A-1 East Wall and Door; Smear $1 \mathrm{~m}^{2} \ldots$. . . A13

A-13 Building 200 Wing M - Cell A-1 East Wall and Door; Smear $100 \mathrm{~cm}^{2} \ldots$ A14

A-14 Building 200 Wing $M$ - Cell A-1 South Walls; RO-20 . . . . . . . . A A15

A-15 Building 200 Wing $M$ - Cell A-1 South Walls; PAC . . . . . . . . . A16

A-16 Building 200 Wing $M$ - Cell A-1 South Walls; Smear $1 \mathrm{~m}^{2} \ldots \ldots \ldots$. . A17

A-17 Building 200 Wing $M$ - Cell A-1 South Walls; Smear $100 \mathrm{~cm}^{2} \ldots \ldots$. . . A18

A-18 Building 200 Wing $M$ - Cell A-1 Floor; RO-20 . . . . . . . . . . A19

A-19 Building 200 Wing $M-$ Cell A-1 Floor; PAC . . . . . . . . . . . A20

A-20 Building 200 Wing $M$ - Cell A-1 Floor; Smear $1 \mathrm{~m}^{2} \ldots \ldots \ldots \ldots$. . . A21

A-21 Building 200 Wing $\mathrm{M}$ - Cell A-1 Floor; Smear $100 \mathrm{~cm}^{2} \ldots \ldots \ldots$. . . A22

A-22 Alpha Spectrum from Radon Gas in Cell A-1 . . . . . . . . . . . A23 
Verification Survey of Building 200 Hot Cells March 1996
$\mathbf{X}$

LIST OF FIGURES continued

No. Title Page

A-23 Alpha-6 Rn \& $\mathrm{Tn}$ Activities in Cell A-1 . . . . . . . . . . . . A23

A-24 RGM-2 Radon Concentration in Cell A-1 . . . . . . . . . . . . . A24

B-1 Building 200 Wing $\mathrm{M}-$ Cell $\mathrm{K}-1 \ldots \ldots \ldots \ldots \ldots \ldots$

B-2 Building 200 Wing $\mathrm{M}-$ Cell $\mathrm{K}-1$ West Wall; RO-20 . . . . . . . . . . B3

B-3 Building 200 Wing $\mathrm{M}$ - Cell K-1 West Wall; PAC . . . . . . . . . . . B4

B-4 Building 200 Wing M - Cell K-1 West Wall; Smear $1 \mathrm{~m}^{2} \ldots \ldots$. . . . B B5

B-5 Building 200 Wing M - Cell K-1 West Wall; Smear $100 \mathrm{~cm}^{2} \ldots \ldots$. . . . B6

B-6 Building 200 Wing $\mathrm{M}$ - Cell $\mathrm{K}-1$ North Wall; RO-20 . . . . . . . . . B7

B-7 Building 200 Wing $\mathrm{M}$ - Cell $\mathrm{K}-1$ North Wall; PAC . . . . . . . . . . B8

B-8 Building 200 Wing $M$ - Cell K-1 North Wall; Smear $1 \mathrm{~m}^{2} \ldots \ldots$. . . . . B9

B-9 Building 200 Wing $M-$ Cell $\mathrm{K}-1$ North Wall; Smear $100 \mathrm{~cm}^{2} \ldots \ldots$

B-10 Building 200 Wing $\mathrm{M}$ - Cell $\mathrm{K}-1$ East Wall; RO-20 . . . . . . . . . . B11

B-11 Building 200 Wing $\mathrm{M}$ - Cell $\mathrm{K}-1$ East Wall; PAC $\ldots \ldots \ldots \ldots$. . . . . B12

B-12 Building 200 Wing $M-$ Cell K-1 East Wall; Smear $1 \mathrm{~m}^{2} \ldots \ldots \ldots$

B-13 Building 200 Wing M - Cell K-1 East Wall; Smear $100 \mathrm{~cm}^{2} \ldots \ldots$. . . . . . B14

B-14 Building 200 Wing $M$ - Cell K-1 South Walls and Door; RO-20 . . . . . B15

B-15 Building 200 Wing $M-$ Cell K-1 South Walls and Door; PAC . . . . . B16

B-16 Building 200 Wing $M-$ Cell $\mathrm{K}-1$ South Walls and Door; Smear $1 \mathrm{~m}^{2} \ldots \ldots$

B-17 Building 200 Wing $\mathrm{M}$ - Cell K-1 South Walls and Door; Smear $100 \mathrm{~cm}^{2}$. . B18

B-18 Building 200 Wing $\mathrm{M}$ - Cell $\mathrm{K}-1$ Floor; RO-20 . . . . . . . . . . . . . B19

B-19 Building 200 Wing $\mathrm{M}$ - Cell K-1 Floor; PAC . . . . . . . . . . . . . B20

B-20 Building 200 Wing $\mathrm{M}$ - Cell $\mathrm{K}-1$ Floor; Smear $1 \mathrm{~m}^{2} \ldots \ldots \ldots \ldots$. . . . . . B21

B-21 Building 200 Wing $\mathrm{M}$ - Cell K-1 Floor; Smear $100 \mathrm{~cm}^{2} \ldots \ldots$. . . . . . B22

B-22 Building 200 Wing M - Cell K-1 Overhead Crane \& Trolley . . . . . . . B23

B-23 Alpha Spectrum from Radon Gas in Cell K-1 . . . . . . . . . . . . . . . . . . . . . . . . . . . . . .

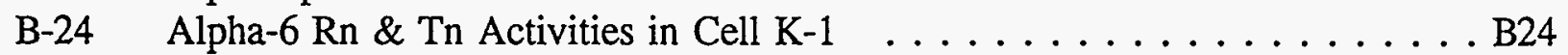

B-25 Cell K-1 Radon Discharge . . . . . . . . . . . . . . . B25

B-26 Cell K-1 Discharge . . . . . . . . . . . . . . . . B26

C-1 Building 200 Wing $\mathrm{M}-$ Cell $\mathrm{K}-3 \ldots \ldots \ldots \ldots \ldots$

C-2 Building 200 Wing $M-$ Cell K-3 West Wall; RO-20 . . . . . . . . . C3

C-3 Building 200 Wing $\mathrm{M}-$ Cell K-3 West Wall; PAC . . . . . . . . . . . C4

C-4 Building 200 Wing M - Cell K-3 West Wall; Smear $1 \mathrm{~m}^{2} \ldots \ldots$. . . . . C5

C-5 Building 200 Wing M - Cell K-3 West Wall; Smear $100 \mathrm{~cm}^{2} \ldots \ldots$. . . . . C6

C-6 Building 200 Wing $\mathrm{M}$ - Cell K-3 North Wall; RO-20 . . . . . . . . . C7

C-7 Building 200 Wing $M-$ Cell K-3 North Wall; PAC . . . . . . . . . . C8

C-8 Building 200 Wing M - Cell K-3 North Wall; Smear $1 \mathrm{~m}^{2} \ldots \ldots$. . . . . . C9

C-9 Building 200 Wing M - Cell K-3 North Wall; Smear $100 \mathrm{~cm}^{2} \ldots \ldots$. . . . C C10

C-10 Building 200 Wing M - Cell K-3 East Walls and Door; RO-20 . . . . . . C11 
Verification Survey of

Building 200 Hot Cells

March 1996 xi

LIST OF FIGURES continued

Page

C-11 Building 200 Wing M - Cell K-3 East Walls and Door; PAC . . . . . C12

C-12 Building 200 Wing M - Cell K-3 East Walls and Door; Smear $1 \mathrm{~m}^{2} \ldots$. . C13

C-13 Building 200 Wing $M$ - Cell K-3 East Walls and Door; Smear $100 \mathrm{~cm}^{2} \ldots$. C14

C-14 Building 200 Wing $M$ - Cell K-3 South Wall; RO-20 . . . . . . . . C15

C-15 Building 200 Wing $M$ - Cell K-3 South Wall; PAC . . . . . . . C16

C-16 Building 200 Wing $M$ - Cell K-3 South Wall; Smear $1 \mathrm{~m}^{2} \ldots \ldots \ldots \ldots$ C17

C-17 Building 200 Wing $M$ - Cell K-3 South Wall; Smear $100 \mathrm{~cm}^{2} \ldots \ldots \ldots$. C18

C-18 Building 200 Wing $\mathrm{M}$ - Cell K-3 Floor; RO-20 . . . . . . . . . . . C19

C-19 Building 200 Wing $M-$ Cell K-3 Floor; PAC . . . . . . . . . . . C20

C-20 Building 200 Wing $M-$ Cell $\mathrm{K}-3$ Floor; Smear $1 \mathrm{~m}^{2} \ldots \ldots \ldots \ldots \ldots$ C21

C-21 Building 200 Wing $M-$ Cell $\mathrm{K}-3$ Floor; Smear $100 \mathrm{~cm}^{2} \ldots \ldots \ldots \ldots$ C22

C-22 Building 200 Wing $\mathrm{M}$ - Cell $\mathrm{K}-3$ Overhead Crane $\ldots \ldots \ldots \ldots \ldots \ldots$ C23

C-23 Alpha Spectrum from Radon Gas in Cell $\mathrm{K}-3 \ldots \ldots \ldots \ldots$. . . . . C24

C-24 Alpha Spectrum from Radon Gas in Cell $\mathrm{K}-1 \ldots \ldots \ldots \ldots \ldots$. . . . . 24

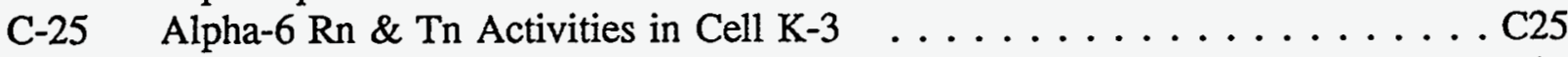

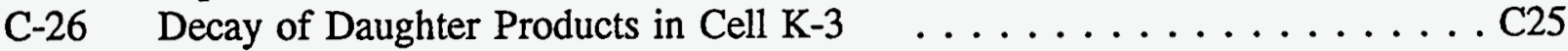

C-27 RGM-2 Radon Concentration in Cell $\mathrm{K}-3 \quad \ldots \ldots \ldots \ldots \ldots \ldots \ldots$. . . 26

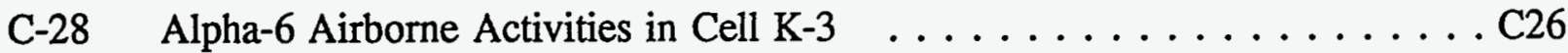

D-1 Building 200 Wing $M-$ Cell $M-3 \ldots \ldots \ldots \ldots$ D2

D-2 Building 200 Wing $\mathrm{M}$ - Cell $\mathrm{M}-3$ West Wall; RO-20 $\ldots \ldots \ldots \ldots \ldots$ D3

D-3 Building 200 Wing $M$ - Cell $M-3$ West Wall; PAC $\ldots \ldots \ldots \ldots \ldots$. . . 4

D-4 Building 200 Wing $M-$ Cell $M-3$ West Wall; Smear $1 \mathrm{~m}^{2} \ldots \ldots \ldots$ D5

D-5 Building 200 Wing $M$ - Cell M-3 West Wall; Smear $100 \mathrm{~cm}^{2} \ldots \ldots \ldots$ D6

D-6 Building 200 Wing $M$ - Cell M-3 North Walls and Door; RO-20 . . . . . D7

D-7 Building 200 Wing $M$ - Cell $M-3$ North Walls and Door; PAC . . . . . . D8

D-8 Building 200 Wing $M$ - Cell M-3 North Walls and Door; Smear $1 \mathrm{~m}^{2} \ldots$. D9

D-9 Building 200 Wing M - Cell M-3 North Walls and Door; Smear $100 \mathrm{~cm}^{2} \ldots$ D10

D-10 Building 200 Wing $M$ - Cell $M-3$ East Wall; RO-20 . . . . . . . . D11

D-11 Building 200 Wing $M$ - Cell $M-3$ East Wall; PAC . . . . . . . . . D12

D-12 Building 200 Wing $M$ - Cell M-3 East Wall; Smear $1 \mathrm{~m}^{2} \ldots \ldots \ldots \ldots$. . . 13

D-13 Building 200 Wing $M$ - Cell M-3 East Wall; Smear $100 \mathrm{~cm}^{2} \ldots \ldots$. . . D14

D-14 Building 200 Wing $M$ - Cell M-3 South Wall; RO-20 . . . . . . . . D15

D-15 Building 200 Wing $M$ - Cell $M-3$ South Wall; PAC $\ldots \ldots \ldots \ldots$. . . 16

D-16 Building 200 Wing $M$ - Cell M-3 South Wall; Smear $1 \mathrm{~m}^{2} \ldots \ldots \ldots \ldots$. . . 17

D-17 Building 200 Wing $M$ - Cell M-3 South Wall; Smear $100 \mathrm{~cm}^{2} \ldots \ldots \ldots$. D18

D-18 Building 200 Wing $\mathrm{M}$ - Cell $\mathrm{M}-3$ Floor; RO-20 . . . . . . . . . . . D19

D-19 Building 200 Wing $M$ - Cell $M-3$ Floor; PAC . . . . . . . . . . D20

D-20 Building 200 Wing $M-$ Cell $M-3$ Floor; Smear $1 \mathrm{~m}^{2} \ldots \ldots \ldots \ldots$. . . 21

D-21 Building 200 Wing $\mathrm{M}$ - Cell M-3 Floor; Smear $100 \mathrm{~cm}^{2} \ldots \ldots \ldots$. . D22 
Verification Survey of Building 200 Hot Cells March 1996 xii

\section{LIST OF FIGURES continued}

No. Title

D-22 Building 200 Wing M - Cell M-3 Floor Pits, Plugs \& Rails . . . . . . . . D23

D-23 Building 200 Wing $M$ - Cell M-3 Overhead Crane \& Trolley . . . . . . . D24

D-24 Alpha Spectrum from Radon Gas in Cell M-3 . . . . . . . . . . . . D25

D-25 Alpha-6 Rn \& Tn Activities in Cell M-3 ............... . . . 25

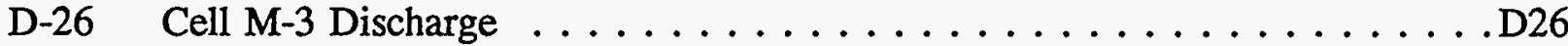

E-1 Building 200 Wing $\mathrm{M}-$ Cell $\mathrm{M}-1 \ldots \ldots \ldots \ldots \ldots \ldots$

E-2 Building 200 Wing $M$ - Cell M-1 West Wall; RO-20 . . . . . . . . . E3

E-3 Building 200 Wing $M-$ Cell $M-1$ West Wall; PAC $\ldots \ldots \ldots \ldots$. . . . . E4

E-4 Building 200 Wing $M-$ Cell M-1 West Wall; Smear $1 \mathrm{~m}^{2} \ldots \ldots$. . . . . E5

E-5 Building 200 Wing $M-$ Cell M-1 North Wall; RO-20 . . . . . . . . . E6

E-6 Building 200 Wing $M-$ Cell $M-1$ North Wall; PAC . . . . . . . . . . E7

E-7 Building 200 Wing $\mathrm{M}$ - Cell M-1 North Wall; Smear $1 \mathrm{~m}^{2} \ldots \ldots$. . . . . E8

E-8 Building 200 Wing $\mathrm{M}$ - Cell $\mathrm{M}-1$ East Wall; RO-20 . . . . . . . . . . E9

E-9 Building 200 Wing $M-$ Cell M-1 East Wall; PAC . . . . . . . . . . . . E10

E-10 Building 200 Wing M - Cell M-1 East Wall; Smear $1 \mathrm{~m}^{2} \ldots \ldots \ldots$. . . . . E11

E-11 Building 200 Wing $M$ - Cell M-1 South Walls and Door; RO-20 . . . . . E12

E-12 Building 200 Wing $M-$ Cell M-1 South Walls and Door; PAC . . . . . . E13

E-13 Building 200 Wing $M$ - Cell M-1 South Walls and Door; Smear $1 \mathrm{~m}^{2} \ldots$. . E14

E-14 Building 200 Wing $\mathrm{M}$ - Cell M-1 Floor; RO-20 . . . . . . . . . . E15

E-15 Building 200 Wing $\mathrm{M}$ - Cell M-1 Floor; PAC .............. E16

E-16 Building 200 Wing $M$ - Cell $\mathrm{M}-1$ Floor; Smear $1 \mathrm{~m}^{2} \ldots \ldots \ldots \ldots$

E-17 Building 200 Wing $M$ - Cell M-1 Floor Pits, Plugs and Rail . . . . . . . E18

E-18 Building 200 Wing $M$ - Cell M-1 Overhead Crane \& Trolley . . . . . . . E19

E-19 Building 200 Wing M - Cell M-1 North Wall Outside . . . . . . . . . E20

E-20 Alpha Spectrum from Radon Gas in Cell M-1 . . . . . . . . . . . . E21

E-21 Alpha-6 Rn \& Tn Activities in Cell M-1 ............... E21

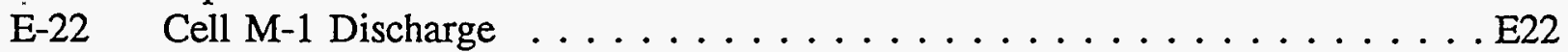


Verification Survey of Building 200 Hot Cells

March 1996 xiii

\section{LIST OF TABLES}

Title

Page

Table i. General Hot Cell Exposure Rates and Emissions . . . . . . . . . . . . i

Table ii. Maximum Survey Results ....................... ii

Table 1. Acceptance Goals Before Painting . . . . . . . . . . . . . . . 8

Table 2. Surface Contamination in Cell A-1 . . . . . . . . . . . . . . . . . . . . . . . . . . . . . .

Table 3. Contamination in Cell A-1 by Isotope . . . . . . . . . . . . . . . . 17

Table 4. Direct Survey Hot Spot Summary; Cell A-1 . . . . . . . . . . . . . . 17

Table 5. ${ }^{220}$ Radon Emissions from Cell K-1 . . . . . . . . . . . . . . . . . . 19

Table 6. Isotopes in Cell $\mathrm{K}-1$ from Stack Emissions . . . . . . . . . . . . . . . . . . . . . . . . . . . . . .

Table 7. Direct Survey Hot Spot Summary; Cell K-1 . . . . . . . . . . . . . . . . . . . . . . . . . . . .

Table 8. ${ }^{220}$ Radon Emissions from Cell K-3 . . . . . . . . . . . . . . 30

Table 9. Isotopes in Cell K-3 from Stack Emissions . . . . . . . . . . . . . . . . 37

Table 10. Direct Survey Hot Spot Summary; Cell K-3 . . . . . . . . . . . . . . . . . . . . . . . . . . .

Table 11. ${ }^{220}$ Radon and ${ }^{85} \mathrm{Krypton}$ Emissions from Cell $\mathrm{M}-3 \ldots \ldots \ldots$

Table 12. Isotopes in Cell M-3 from Stack Emissions . . . . . . . . . . . . . . . . . . . . . . . . . . . . . . .

Table 13. Direct Survey Hot Spot Summary; Cell M-3 . . . . . . . . . . . . . . . 47

Table 14. ${ }^{85}$ Krypton and ${ }^{129}$ Todine Emissions from Cell $\mathrm{M}-1 \ldots \ldots \ldots$

Table $15 .{ }^{220}$ Radon Emissions from Cell $\mathrm{M}-1 \ldots \ldots \ldots \ldots \ldots \ldots$

Table 16. M-1 Core Sample Results ... . . . . . . . . . . . . . . . 57

Table 17. Isotopes in Cell M-1 from Stack Emissions . . . . . . . . . . . . . . . . . . . . . 60

Table 18. Direct Survey Hot Spot Summary; Cell M-1 . . . . . . . . . . . . . . 61 
Verification Survey of Building 200 Hot Cells March 1996 xiv

\section{ABBREVIATIONS AND ACRONYMS}

ACL AGHCF ALARA Alpha-6 ANL anti-C CAM CHM CMT

$D \& D$

DOE

DOT

dpm

ESH

HEPA

HP

NE

POB

PAC 4G-3

Radon

RGM-2

RO-20

ROI

Thoron

TLD

TRU

WIPP
Analytical Chemistry Laboratory

Alpha Gamma Hot Cell Facility

As Low As Reasonably Achievable

Eberline Alpha-6 Continuous Air Monitor (CAM)

Argonne National Laboratory

anti contamination clothing (coveralls, gloves, shoe covers)

Continuous Air Monitor

Chemistry Division

Chemical Technology Division

Decontamination and Decommissioning

Department of Energy

Department of Transportation

disintegrations per minute

Environment Safety and Health Division

High Efficiency Particulate Air Filter

Health Physics Section of ESH

NE Technology Limited Electra/DP6 Alpha/Beta Scintillation Detector Proof of Breeding

Eberline Gas Proportional Detector

Radon-222 ( $\left.{ }^{22} \mathrm{Rn}\right)$

Eberline Radon Gas Monitor

Eberline RO-20 Ion Chamber

Region of Interest

Radon-220 (20 Rn)

Thermoluminescent Dosimeter

Trans-uranic

Waste Isolation Pilot Plant 


\section{VERIFICATION SURVEY OF \\ BUILDING 200 HOT CELLS}

\section{HISTORY}

\section{A. Description of the Shielded Cave Complex}

The Chemistry (CHM) Division shielded "Cave Complex" is a monolithic concrete structure two stories in height. The lower floor includes four megacurie cells (cells $\mathrm{M}-1, \mathrm{M}-2$, $\mathrm{M}-3$ and $\mathrm{M}-4$, see Figure 1). On the main floor, there exist two large (K-1 and $\mathrm{K}-2)$ and one small (K-3) kilocurie cells, one double (A-5) and four single-sized (A-1, A-2, A-3, and A-4) analytical cells. There is also a sample storage area (M-6) and an area where shipping casks can be loaded or unloaded (M-5).

A common shielded transport corridor on both levels of the complex allows for entrance and exit of highly radioactive materials from any cell without disrupting ongoing work in other cells. There are 40 viewing windows which allow handling of materials inside the cells remotely from outside the windows. The manipulators are fitted with air restriction devices to limit airflow through the manipulator port in the event of failure of the sealed manipulator boot.

Heavier moving is handled by remotely operated bridge cranes. Each of the megacurie cells and the two large kilocurie cells have a one-ton capacity bridge crane, and two-ton capacity cranes exist in the pot unloading and lower floor transfer corridor areas. A five-ton monorail hoist is available on the main floor at the entrance. A ten-ton bridge crane operates over the loading dock at the west end of the building and the paved area beyond the dock. All cranes and self-propelled manipulators are operated remotely by control stations located outside the shielding walls at suitable window positions.

A narrow-gage (36-inch) railway track system runs into all areas of the cell complex and connects the individual cells with the central corridor and the pot unloading area. Battery driven, radio-controlled flat carts, "mules", traverse these tracks. These carts are remotely operated from outside the shielded areas by a small radio transmitter. The transmitter plugs into the cave antenna system at various shielding windows. Remotely operated turntables on the 
main and lower floors at suitable positions permit right-angle changes in direction, while the hydraulic elevator, into which the track runs, permits remotely controlled movement of the mules between floors.

The ventilation system of the complex is controlled such that, with the external doors closed, the airflow is from the cold (clean) operating areas to the suspect transfer areas through the shielding walls to the interior transfer corridors and from there to the cells and out through the fan loft. Ventilation barriers isolate the pot loading area and the corresponding entrance area on the main floor from the rest of the complex.

Air from the lighter-duty analytical cells is filtered through one prefilter in the cell and one HEPA filter in the fan loft before being exhausted to the atmosphere. In the other cells, the air is filtered as it leaves the cell and again through two HEPA filters in the fan loft. The mounting for the in-cell filter is such that it can be changed remotely with the use of manipulators if necessary.

\section{B. Pre-Proof of Breeding}

The CHM Shielded Cave Complex was constructed in the early sixties with an original mission of conducting actinide research and isotope separation chemistry. During the seventies and eighties the facility became a user facility for projects outside the Chemistry Division. After a project was completed, the cell was decontaminated and/or painted to fix the residual contamination.

\section{Proof of Breeding}

The Proof of Breeding (POB) Project began in 1975. The POB project at Argonne National Laboratory (ANL) was part of a national effort sponsored by the Department of Energy (DOE) to develop technology for breeding uranium-233 $\left.{ }^{233} \mathrm{U}\right)$ from thorium-232 $\left({ }^{232} \mathrm{Th}\right)$ in lightwater reactors (see Figure 2). In the process of breeding ${ }^{233} \mathrm{U}$, the reactor also generated ${ }^{232} \mathrm{U}$ (72 year half-life) which decays to Radon-220 $\left({ }^{20} \mathrm{Rn}\right.$ ) which is historically referred to as thoron.

${ }^{220} \mathrm{Rn}$ is also the decay product of naturally occurring ${ }^{232} \mathrm{Th}$ with a $10^{10}$ year half-life. Small components of concrete are naturally occurring uranium and thorium in equilibrium with their 
March 1996

decay products; ${ }^{238} \mathrm{U}$ (4.5x $10^{9}$ year half-life) and ${ }^{234} \mathrm{U}\left(2.4 \times 10^{5}\right.$ year half-life) decay to Radon-222 $\left({ }^{222} \mathrm{Rn}\right)$ which is historically referred to as radon; and ${ }^{235} \mathrm{U}\left(7.0 \times 10^{8}\right.$ year half-life) decays to Radon-219 $\left({ }^{19} \mathrm{Rn}\right)$ which is historically referred to as actinon. The decay schemes of radon, thoron and actinon are shown in Figure 3. Since radon is a noble gas, it readily becomes airborne when it is on surfaces that are exposed to the air.

Air was sampled in the clean operating area in the Building 200 service area with an Alpha-6 (Eberline Alpha-6 continuous air monitor). The alpha spectrum is presented in Figure 4 and the radon activities are presented in Figure 5. The Alpha- 6 monitor detects alpha particles, measures the energy, and accumulates the data to produce an alpha spectrum. Therefore, it can distinguish between radon $(\mathrm{Rn})$, thoron $(\mathrm{Tn})$ and actinon (An) decay products. Three peaks are seen in this spectrum; one, ${ }^{212} \mathrm{Po}(8.78 \mathrm{MeV})$, from thoron; one, ${ }^{214} \mathrm{Po}$ (7.69 $\mathrm{MeV})$, from radon; and one from a combination of ${ }^{218} \mathrm{Po}(6.00 \mathrm{MeV})$ from radon and ${ }^{212} \mathrm{Bi}(6.05$ $\mathrm{MeV}$ ) from thoron. Here the ${ }^{214} \mathrm{Po}$ peak from ${ }^{222} \mathrm{Rn}$ dominates the spectrum and the radon daughter activity is greater than the thoron daughter activity. The Alpha- 6 calculates ${ }^{222} \mathrm{Rn}$ concentrations in $\mathrm{pCi} / \mathrm{l}$ and radon and thoron daughter concentrations in milli Working Levels $(\mathrm{mWL})$. For ${ }^{220} \mathrm{Rn}$ a Working Level is defined as any combination of short-lived radon daughters $\left({ }^{212} \mathrm{~Pb},{ }^{212} \mathrm{Bi}\right.$, and $\left.{ }^{212} \mathrm{Po}\right)$ in one liter of air that will result in the "ultimate emission" of $1.3 \times 10^{5} \mathrm{MeV}$ of alpha particle energy. The alpha emission of ${ }^{216} \mathrm{Po}$ is ignored since its half live is 150 milliseconds. For ${ }^{222} \mathrm{Rn}$ a Working Level is defined as any combination of short-lived radon daughters $\left({ }^{218} \mathrm{Po},{ }^{214} \mathrm{~Pb},{ }^{214} \mathrm{Bi}\right.$, and ${ }^{214} \mathrm{Po}$ ) in one liter of air that will result in the "ultimate emission" of $1.3 \times 10^{5} \mathrm{MeV}$ of alpha particle energy. The alpha emission of ${ }^{210} \mathrm{Po}$, delayed by a 21 year half live, is excluded from the "ultimate emission" definition.

Before equipment was installed in the hot cells, each cell was decontaminated to levels such that there was no need for personnel protective equipment (PPE), anti contamination (antiC) clothing and respiratory protection, during the installation and testing phase of the project. During the $\mathrm{POB}$ project's main campaign at ANL, there was destructive analysis of seventeen fuel rods from the Shippingport Light Water Breeder Reactor, which had operated from September 1977 to October 1982. Operation on the actual fuel rods began in August 1984 and was completed in November 1985. ANL performed a destructive evaluation to determine (1) 
the isotopic composition of the uranium, (2) the total uranium content, and (3) the amount of selected fission products contained in the irradiated fuel. The results of the POB project were used to verify and validate a nondestructive examination technique developed by the Bettis Atomic Power Laboratory to determine the fissile ${ }^{233} \mathrm{U}$ content of the fuel rods.

The irradiated fuel rods were received at ANL in segments of about 6" to 30 " $(15 \mathrm{~cm}$ to $75 \mathrm{~cm}$ ) lengths. They were sheared in cell M-3 into pieces about half the rod diameter in height. The sheared pieces were taken to cell M-1 and dissolved in acid solutions. The solutions were sampled and the samples were taken to cell $\mathrm{K}-3$ for examination and preparation for further gamma and chemical analysis outside the cell. The solutions were converted to a cemented waste and were shipped to Hanford for storage and potential final placement in the Waste Isolation Pilot Plant (WIPP). Non-transuranic waste was cemented and stored in cell K-1. Graczyk et al (1987) provides a detailed description of the facilities and equipment used, the operations, and the results of the $\mathrm{POB}$ project.

It was initially planned to restore the cells upon completion of the research work. However, at the close of the project funding for the final clean-up of the cells was not available due to budget restraints. Because the stack emissions from cells $\mathrm{M}-1$ and $\mathrm{K}-1$ were high some cleaning was performed in 1987. Some of the waste from the project was packaged in four 55 gallon drums and stored in cell M-4. The contaminated equipment, cells and waste were abandoned until funding became available for the clean-up. From 1987 through Spring 1992, the cells used by the POB project were idle and discharged large quantities of ${ }^{220} \mathrm{Rn}$ gas from the stacks of the Cave Complex, mainly from cells $\mathrm{M}-1$ and $\mathrm{K}-1$. The emissions from cells $\mathrm{K}-3$ and $\mathrm{M}-3$ were $\leq 1 \%$ of either the cell $\mathrm{K}-1$ or the cell $\mathrm{M}-1$ emissions.

The Building $200 \mathrm{M}$-Wing Hot Cell D\&D project was primarily concerned with decontamination to "restricted use" of cells $\mathrm{M}-1, \mathrm{M}-3, \mathrm{~K}-1, \mathrm{~K}-3$ and $\mathrm{A}-1$. Work on the project was initiated in the spring of 1992 with the goal of reducing emissions to less than $10 \%$ of the 1991 emissions and reducing the external exposure rate in the cell to $\leq 1 \mathrm{mR} / \mathrm{h}$ with no loose contamination (April 1993). 
March 1996

\section{D. ${ }^{231} \mathrm{~Pa}$ work in Cell K-3}

In 1991 a 1.5 gram ${ }^{231} \mathrm{~Pa}$ source was subdivided and repackaged into smaller containers because of concern for the integrity of the original container. This source had been placed in storage on May 1, 1973. Since K-3 was relatively clean, it was used for the work on the source. After the source was repackaged into several smaller sources, they were removed from the cell. One of the sources was shipped to Berkeley, California. A gamma spectrometric analysis, performed to obtain the data required on the shipping documents, was consistent with an assumption that the sample was originally purified during 1971. Therefore, the ${ }^{227} \mathrm{Ac}$ activity is presently $\sim 54 \%$ of the ${ }^{231} \mathrm{~Pa}$ activity. As seen in Figure $3,{ }^{231} \mathrm{~Pa}$ and ${ }^{227} \mathrm{Ac}$ decay to ${ }^{219} \mathrm{Rn}$.

\section{E. Zion}

The A-1 cell was used for examination of irradiated fuel ${ }^{235} \mathrm{U}$ and $\left.{ }^{239} \mathrm{Pu}\right)$ from the Zion reactor in early 1985. 500 grams of irradiated fuel from the Zion reactor were received in ten 2-inch long rod segments. The rods were sheared into smaller pieces, cladding was removed and the fuel was pulverized in enclosed small stainless capsules. Samples of pulverized fuel each weighing 0.2 grams were dissolved in acid solutions. The solutions were analyzed to determine the composition of the fuel. The project was intended to experimentally test computational methods which were being developed for determining the fuel isotopic dynamics in reactor operations. The project and the results obtained are described in Heinrich et al 1985.

Before equipment was installed in hot cell $\mathrm{A}-1$, it had been decontaminated to levels such that there was no need for anti-C clothing or respiratory protection during the installation of the equipment. At the beginning of the D\&D project the cell was not in use. After the Zion fuel examination project ended, the equipment and the structures were not cleaned and the fuel was not removed from the cell.

The inventory of radioactive material in cell A-1 at the start of the D\&D project was essentially the entire inventory in the 500 grams of fuel received from Zion minus the amount lost due to radioactive decay. Most of the fuel was in powder form in stainless steel pipe nipples. There was also about $200-300 \mathrm{ml}$ of mixed waste containing about 2 grams of fuel dissolved in hydrochloric acid, nitric acid and a small quantity of hydrofluoric acid. There was 
also a jar containing Zircaloy cladding. Some fuel dust was expected to reside on the surfaces in the cell from escaped wisps of air during opening of pulverization equipment.

The fuel in cell A-1 contained $\sim 4$ grams of ${ }^{239} \mathrm{Pu}(24,131$ year half-life $)$ and $\sim 4$ grams of ${ }^{235} \mathrm{U}\left(7.0 \times 10^{8}\right.$ year half-life $)$ and ${ }^{238} \mathrm{U}\left(4.5 \times 10^{9}\right.$ year half-life). The air in the stacks from this cell was never sampled because the fuel did not decay to a radon isotope. There are two decay products between ${ }^{238} \mathrm{U} /{ }^{234} \mathrm{U}$ and ${ }^{222} \mathrm{Rn}$ with long half-lives $\left({ }^{230} \mathrm{Th} ; 7.7 \times 10^{4}\right.$ years and ${ }^{226} \mathrm{Ra} ; 1600$ years) preventing the generation of ${ }^{222} \mathrm{Rn}$; and there is one decay product between ${ }^{239} \mathrm{Pu} /{ }^{235} \mathrm{U}$ and ${ }^{219} \mathrm{Rn}$ with a long half life $\left({ }^{231} \mathrm{~Pa} ; 3.3 \times 10^{4}\right.$ years) preventing the generation of ${ }^{219} \mathrm{Rn}$. There is also another decay product, ${ }^{227} \mathrm{Ac}$, with a 21.7 year half-life. Therefore, any ${ }^{222} \mathrm{Rn}$ or ${ }^{219} \mathrm{Rn}$ generated by the fuel in A-1 was much less than that generated from the naturally occurring ${ }^{238} \mathrm{U}$ and ${ }^{235} \mathrm{U}$ inherent in all concrete.

The air in the stacks from the POB cells was sampled because the ${ }^{232} \mathrm{U}$ decays to a radon isotope. The longest half-life of the decay products between ${ }^{232} \mathrm{U}$ and ${ }^{220} \mathrm{Rn}$ is only 1.9 years $\left({ }^{228} \mathrm{Th}\right)$. Therefore there were large quantities of ${ }^{220} \mathrm{Rn}$ emitted from the stacks of the cells used in the $\mathrm{POB}$ project. 


\section{FINAL SURVEY PROCEDURES}

Final verification surveys were performed by ESH-HP personnel. Each Health Physics Technician who performed the survey in the cell wore anti-C clothing and an air purifying respirator. Most of the time there were two Health Physics Technicians inside the large cells. One or both of these workers had radio communication with the data recorder(s) outside the cell. For the small cells such as A-1, there was room for only one person to survey the cell.

\section{A. Grid}

After the cell was decontaminated, the cell was divided into one meter square grids on each of the six walls and the floor. Construction chalk was used to snap the grids lines on the walls and floor. The intersections of the grid lines were marked in pen on the floor only. The origin of the floor grid was at the south west corner. The origin of the wall grids were at the floor and the south or west edge of the wall (see for example Figure A-1).

\section{B. Acceptance Goals}

Because of the time required to decontaminate below detectable levels, acceptance goals prior to painting were established. Since decontamination of the ventilation ductwork was not part of the scope of work, higher exposure rates were established for the filters and housings. The procedures for the final radiological cell survey, SOP 4.9 , define the acceptance goals as presented in Table 1.

\section{Direct $\alpha$ Survey}

Each grid was surveyed direct with an Eberline PAC 4G-3 gas proportional monitor in the alpha mode. This instrument was chosen because there is no cross over from the residual beta or gamma contamination in the cell into the alpha detector. During the grid survey, the hot spot(s) and the general background measurements were logged directly on a cell map. The meter readings were communicated by radio to the recorder outside the cell. The recorder could visually determine the location of the meter reading through a viewing window. The activities 
were calculated and compared to the total $\alpha$ activity maximum and average goals.

Table 1. Acceptance Goals Before Painting

\begin{tabular}{|c|c|c|}
\hline \multicolumn{3}{|c|}{ Allowable Residual Contamination } \\
\hline & Average & Maximum \\
\hline Removable $^{1 /} \alpha$ Activity & $\begin{array}{l}200 \mathrm{dpm} / 100 \mathrm{~cm}^{2} \\
20,000 \mathrm{dpm} / 1 \mathrm{~m}^{2}\end{array}$ & $800 \mathrm{dpm} / 100 \mathrm{~cm}^{2}$ \\
\hline Total $^{2 /} \alpha$ Activity & $1,000 \mathrm{dpm} / 100 \mathrm{~cm}^{2}$ & $3,000 \mathrm{dpm} / 100 \mathrm{~cm}^{2}$ \\
\hline Removable $^{1 /} \beta \gamma$ Activity & $\begin{array}{l}10,000 \mathrm{dpm} / 100 \mathrm{~cm}^{2} \\
1,000,000 \mathrm{dpm} / 1 \mathrm{~m}^{2}\end{array}$ & $50,000 \mathrm{dpm} / 100 \mathrm{~cm}^{2}$ \\
\hline $\begin{array}{c}\text { Total }^{21} \gamma \text { Exposure } \text { rate }^{3 /} \text { on } \\
\text { contact }\end{array}$ & $1 \mathrm{mR} / \mathrm{h}$ & $5 \mathrm{mR} / \mathrm{h}$ \\
\hline $\begin{array}{l}\text { Total }^{2 /} \gamma \text { Exposure rate }{ }^{3 /} \text { at } \\
\text { opening Exhaust Ducts; } \\
\text { HEPA filter housing }\end{array}$ & $10 \mathrm{mR} / \mathrm{h}$ & $50 \mathrm{mR} / \mathrm{h}$ \\
\hline
\end{tabular}

\section{Direct $\boldsymbol{\gamma}$ Survey}

Each grid was surveyed direct with an Eberline RO-20 with the beta shield closed in order to measure only gamma (deep) dose and to eliminate the beta (shallow) dose. This instrument was chosen because it is an ion chamber and it can distinguish beta activity from gamma activity. During the grid survey, the hot spot(s) and the general background measurements were logged directly on a cell map. The meter readings were communicated by radio to the recorder outside the cell. The recorder could visually determined the location of the meter reading through a viewing window. The exposure rates were compared to the maximum and average location specific goals.

\section{E. Large Area Smears and Small Area Smears}

Each square meter grid was smeared with a single paper over the entire area. Grids that contained less than a $1 \mathrm{~m}^{2}$ area were not combined with other small grids. Each smear was 
counted with an NE Technology Limited Model Electra/DP6 Alpha Beta ZnS(Ag) scintillation detector in the integrate mode for one minute for both alpha and beta-gamma activity. The smears results were tabulated and the activity was calculated and logged on a cell map. The activities are compared to the average removable activities. For ease of comparison, the average removable values are presented as $d p m / 1 \mathrm{~m}^{2}$ below the $\mathrm{dpm} / 100 \mathrm{~cm}^{2}$ values in Table 1 .

During a separate entry, a $100 \mathrm{~cm}^{2}$ smear was taken near the center of each grid. Each smear was counted for one minute for both alpha and beta-gamma activity with an NE in the integrate mode. The smears results were tabulated and the activities were calculated and logged on a cell map. The activities are compared to the maximum removable values. 


\section{CELL A-1}

\section{A. INITIAL CELL CONDITION}

\section{Spills and Contamination}

In cell A-1 there were no known spills. There were large amounts of loose contamination and airborne contamination inside the cell. Work on the Zion fuel was performed inside a containment box on a work table.

\section{Stack Emissions}

Monitoring of the cell A-1 stack emissions was never initiated because neither ${ }^{219} \mathrm{Rn}$ nor ${ }^{222} \mathrm{Rn}$ was generated from the fuel as explained in section I.E.

\section{B. DECONTAMINATION}

Figure 6 indicates the period of time that work was being performed in the five cells that had the potential for accumulating external exposures. The deep doses that were actually accumulated are shown in figure 7. They were consistently less than the shallow doses shown in figure 8 or the ring doses shown in figure 9.

\section{Waste Removed}

Cell A-1 was remotely cleaned and waste was remotely packaged in the cell starting during October 1993. The fuel was transferred to the Building 212 Alpha Gamma Hot Cell Facility (AGHCF) in May 1994. The remote handled waste was also transferred to cell M-3 during the same month. Once the remote waste was removed, the dose rate in the cell was low. The entry tent was constructed and the anteroom was entered during May. The cell was originally considered completely decontaminated during September 1994. However in March 1995 the cell was rechecked prior to the final survey and found to have high levels of contamination. Further decontamination was performed prior to the final survey during June 1995. 
March 1996

\section{Accumulated Dose}

Personnel doses were tracked with SAIC dosimeters which responds well to deep dose. These dosimeter have two alarm points, one for dose rate and the second for accumulated dose. If the alarm points were properly set, the people actually performing the work in the cells had the ability to keep their doses as low as reasonably achievable (ALARA) during the performance of the work. They were able to minimize their time in fields above the dose rate alarm level. When the accumulated dose reached the alarm point, the entry was terminated. A running total of the monthly doses for cell entries were kept for each worker. Attempts were made to keep the monthly total for each worker below $100 \mathrm{mrem}$, the Argonne administrative exposure control guide. This was done successfully for all cells except cell M-1, where a conscious decision was made to exceed this dose for one month.

The doses of record were those measured by the thermoluminescent dosimeter (TLD) badge. Both deep and shallow doses were measured by this badge. In addition ring dosimeters were worn. Both the TLD badges and the ring dosimeters were changed monthly. It was found that there were times when there was a large shallow dose and a smaller deep dose. At those times, the SAIC dosimeter appeared to be responding to the shallow dose. It was also noticed that the SAIC dosimeter responded to a hand held radio, increasing the reading when there was only a background radiation field.

The total whole body (deep) dose that was accumulated during the decontamination of cell A-1 was $\sim 330$ person-mrem (see Figure 7). The total skin (shallow) dose was $\sim 840$ person-mrem (see Figure 8 ) and the total extremity (ring) dose was $\sim 650$ person-mrem (see Figure 9). The A-1 doses were estimated as $1 / 3$ of those accumulated from May 1994 through August 1994 and $1 / 6$ of those accumulated in September 1994. Although initial entries were made at the end of May, decontamination of cell K-1 was also being performed during the same time period.

\section{Decontamination Limit}

The cell was decontaminated to the paint layer. Numerous attempts were made to remove loose contamination that was on the paint. However, no attempt was made to remove 
the paint or the contamination under the paint. The prefilter in the cell was replaced and the accessible exhaust duct was decontaminated after the loose contamination increased between September 1994 and March 1995.

\section{FINAL SURVEY RESULTS}

The values that were measured during the survey are compared to the acceptance goals. For each graph containing the direct survey data, the average grid measurements are presented in large numbers in the center of the grid; the elevated readings are presented in smaller numbers at the location of the hot spots. In the legend, the instrument and the corresponding units of the measurements are designated for direct surveys. The smear data is presented as a ratio with the alpha activity printed in the numerator to the beta-gamma activity printed in the denominator. The legend indicates whether the smear covered the large $1 \mathrm{~m}^{2}$ or the small 100 $\mathrm{cm}^{2}$ area near the center of the grid. The layout of cell A-1 is shown in Figure A-1.

\section{A-1 West Wall}

The filter housing on the west wall exhibits high direct radiation levels $(8 \mathrm{mR} / \mathrm{h})$ seen in Figure A-2. At $30 \mathrm{~cm}$ from the filter, the exposure rate decreased to $2 \mathrm{mR} / \mathrm{h}$. In general the gamma readings ranged from $2 \mathrm{mR} / \mathrm{h}$ to $10 \mathrm{mR} / \mathrm{h}$. The hot spots ranged from $2.5 \mathrm{mR} / \mathrm{h}$ to 30 $\mathrm{mR} / \mathrm{h}$. Neither the averages nor the hot spots meet the average and the maximum exposure rate goals on contact.

The average alpha readings in each grid ranged from $400 \mathrm{dis} / \mathrm{min}$ to $10,000(10 \mathrm{k}) \mathrm{dis} / \mathrm{min}$ using a $61 \mathrm{~cm}^{2}$ probe. The values near the ceiling are above the average alpha activity acceptance goal for $100 \mathrm{~cm}^{2}$. The direct alpha readings of the hot spots ranged between $4 \mathrm{k}$ dis/min and 1,000,000 (1M) dis/min using a $61 \mathrm{~cm}^{2}$ probe (see Figure A-3). All were above the maximum total $\alpha$ activity acceptance goal for $100 \mathrm{~cm}^{2}$.

The removable contamination goal is stated in terms of a $100 \mathrm{~cm}^{2}$ area. Therefore, the $1 \mathrm{~m}^{2}$ smear data are compared to values 100 times the averages. The maximum loose activity was $12 \mathrm{k} \mathrm{dpm} / 1 \mathrm{~m}^{2} \alpha$ and $510 \mathrm{k} \mathrm{dpm} / 1 \mathrm{~m}^{2} \beta \gamma$, below the Table 1 values (see Figure A-4). The 
highest removable activity was in the grids at the top of the wall. The $100 \mathrm{~cm}^{2}$ smears were taken near the center of each grid. The highest alpha activity was $520 \mathrm{dpm} / 100 \mathrm{~cm}^{2}$; the highest $\beta \gamma$ activity was $12 \mathrm{k} \mathrm{dpm} / 100 \mathrm{~cm}^{2}$ (see Figure A-5). Both are below the maximum removable activity goals.

\section{A-1 North Wall}

The grid average ranged from $1.0 \mathrm{mR} / \mathrm{h}$ to $10 \mathrm{mR} / \mathrm{h}$ (see Figure A-6). The hot spots ranged from $2 \mathrm{mR} / \mathrm{h}$ to $20 \mathrm{mR} / \mathrm{h}$. Most of the measurements were at or above the average contact exposure rate goal.

The average alpha readings in each grid range from $400 \mathrm{dis} / \mathrm{min}$ to $100 \mathrm{k} \mathrm{dis} / \mathrm{min}$ using a $61 \mathrm{~cm}^{2}$ probe (see Figure A-7). The hot spots range from $1 \mathrm{k} \mathrm{dis} / \mathrm{min}$ to $500 \mathrm{k} \mathrm{dis} / \mathrm{min}$. The top east grid average is above the acceptance goal. Many of the hot spots on this wall exceed the acceptance goals. The top grids have the highest readings.

The maximum large area loose activity was $3.9 \mathrm{k} \mathrm{dpm} / 1 \mathrm{~m}^{2} \alpha$ and $120 \mathrm{k} \mathrm{dpm} / 1 \mathrm{~m}^{2} \beta \gamma$ in the upper west grid, these values are well below the average acceptance goals (see Figure A-8). The highest small area loose alpha activity was $6.4 \mathrm{k} \mathrm{dpm} / 100 \mathrm{~cm}^{2}$; the highest $\beta \gamma$ activity was $160 \mathrm{k} \mathrm{dpm} / 100 \mathrm{~cm}^{2}$ (see Figure A-9). Both are above the maximum removable acceptance goals.

\section{A-1 East Wall and Door}

The east wall includes the door and the section above the door. The average gamma readings were $1.0 \mathrm{mR} / \mathrm{h}$ on the east wall and $0.5 \mathrm{mR} / \mathrm{h}$ on the door (see Figure A-10). No measurements were above the average exposure rates on contact.

The average alpha readings in each grid range from $100 \mathrm{dis} / \mathrm{min}$ to $20 \mathrm{k} \mathrm{dis} / \mathrm{min}$ using a $61 \mathrm{~cm}^{2}$ probe (see Figure A-11). The upper north grid value was above the average total alpha activity acceptance goal. The direct alpha readings for the hot spots were between $5 \mathrm{k}$ dis/min and $100 \mathrm{k} \mathrm{dis} / \mathrm{min}$ using a $61 \mathrm{~cm}^{2}$ probe. All of these values are above the maximum total $\alpha$ activity acceptance goal for a $100 \mathrm{~cm}^{2}$ area.

The maximum large area loose activity was $630 \mathrm{dpm} / 1 \mathrm{~m}^{2} \alpha$ and $35 \mathrm{k} \mathrm{dpm} / 1 \mathrm{~m}^{2} \beta \gamma$, well below the average removable alpha activity acceptance goal (see Figure A-12). The highest 
small area loose alpha activity was $180 \mathrm{dpm} / 100 \mathrm{~cm}^{2}$; the highest $\beta \gamma$ activity was $9.0 \mathrm{kdpm} / 100$ $\mathrm{cm}^{2}$ (see Figure A-13). Both are below the maximum removable activity acceptance goals.

\section{A-1 South Wall}

The average gamma readings were between $1.0 \mathrm{mR} / \mathrm{h}$ and $2.0 \mathrm{mR} / \mathrm{h}$ (see Figure A-14). These measurements are at or above the average contact exposure rate goals. The hot spots ranged from $3 \mathrm{mR} / \mathrm{h}$ to $20 \mathrm{mR} / \mathrm{h}$. Some of the hot spots were above the respective maximum contact exposure rate goals. These hot spots are associated with the exhaust duct and the transfer port. At $30 \mathrm{~cm}$ from the exhaust duct, the exposure rate decreased to $2 \mathrm{mR} / \mathrm{h}$.

The average alpha readings in each grid range from $400 \mathrm{dis} / \mathrm{min}$ to $10 \mathrm{k}$ dis $/ \mathrm{min}$ using a $61 \mathrm{~cm}^{2}$ probe (see Figure A-15). The values at the top of the wall were above the average total alpha activity acceptance goal for $100 \mathrm{~cm}^{2}$. The direct alpha readings for the hot spots were between $600 \mathrm{dis} / \mathrm{min}$ and $1 \mathrm{M} \mathrm{dis} / \mathrm{min}$ using a $61 \mathrm{~cm}^{2}$ probe. Many of these values are above the maximum total $\alpha$ activity acceptance goal for $100 \mathrm{~cm}^{2}$.

The maximum large area loose activity was $14 \mathrm{k} \mathrm{dpm} / 1 \mathrm{~m}^{2} \alpha$ and $380 \mathrm{k} \mathrm{dpm} / 1 \mathrm{~m}^{2} \beta \gamma$, well below the average removable acceptance goals (see Figure A-16). The highest small area loose alpha activity was $520 \mathrm{dpm} / 100 \mathrm{~cm}^{2}$; the highest $\beta \gamma$ activity was $15 \mathrm{k} \mathrm{dpm} / 100 \mathrm{~cm}^{2}$ (see Figure A-17). Both are below the maximum removable activity acceptance goals. The smears with the highest loose activities were all in the upper west grid.

\section{A-1 Floor}

The average gamma readings on the cell floor were $1.0 \mathrm{mR} / \mathrm{h}$ (see Figure A-18). These measurements are equal to the average contact exposure rate acceptance goals. The hot spots ranged from $3 \mathrm{mR} / \mathrm{h}$ to $8 \mathrm{mR} / \mathrm{h}$, most were below the maximum contact exposure rate acceptance goal. The general exposure rate at $13 / 4$ meter above the floor was $2.5 \mathrm{mR} / \mathrm{h}$. This is above the $1 \mathrm{mR} / \mathrm{h}$ goal.

The average alpha readings in each grid were between $4 \mathrm{k} \mathrm{dis} / \mathrm{min}$ and $50 \mathrm{k} \mathrm{dis} / \mathrm{min}$ using a $61 \mathrm{~cm}^{2}$ probe (see Figure A-19). These are above the acceptance goal. The direct alpha 
Verification Survey of

Building 200 Hot Cells

March 1996

readings for the hot spots were between $8 \mathrm{k}$ dis $/ \mathrm{min}$ and $1 \mathrm{M}$ dis $/$ min using a $61 \mathrm{~cm}^{2}$ probe. All of these values are above the maximum total $\alpha$ activity acceptance goal for $100 \mathrm{~cm}^{2}$.

The maximum large area loose activity was $15 \mathrm{k} \mathrm{dpm} / 1 \mathrm{~m}^{2} \alpha$ and $440 \mathrm{k} \mathrm{dpm} / 1 \mathrm{~m}^{2} \beta \gamma$, well below the average removable activity acceptance goals (see Figure A-20). The highest small area loose alpha activity was $1.1 \mathrm{kdpm} / 100 \mathrm{~cm}^{2}$; the highest $\beta \gamma$ activity was $32 \mathrm{kdpm} / 100$ $\mathrm{cm}^{2}$ (see Figure A-21). The highest alpha smear is above and the highest beta smear is below the maximum removable acceptance goal.

\section{CONCLUSIONS}

Since the paint that was used to fix the contamination from the earlier projects was not removed, contamination remains under this paint. The present survey gives the level of activity in the cells at the end of the decontamination effort.

\section{Measurements of Residual Radon Gas}

The amount of thoron, radon and actinon in cell A-1 were measured by two monitors, a Radon Gas Monitor (RGM-2) and an Alpha-6. The RGM-2 monitor was calibrated with ${ }^{220} \mathrm{Rn}$ generated from a ${ }^{228} \mathrm{Th}$ standard source. The RGM-2 measures the total radon concentration $\left({ }^{219} \mathrm{Rn}+{ }^{220} \mathrm{Rn}+{ }^{222} \mathrm{Rn}\right)$. It filters out the radon daughters before the gas enters the counting chamber but it can not distinguish between the radon isotopes. The Alpha- 6 monitor detects alpha particles from the radon decay products, measures the energy, and accumulates the data to produce an alpha spectrum (see Figure A-22). Therefore, it can distinguish between radon $(\mathrm{Rn})$, thoron $(\mathrm{Tn})$ and actinon $(\mathrm{An})$. Three prominent peaks are seen in this spectrum; one, ${ }^{212} \mathrm{Po}$ $(8.78 \mathrm{MeV})$, from thoron; one, ${ }^{214} \mathrm{Po}(7.69 \mathrm{MeV})$, from radon; and one from a combination of ${ }^{218} \mathrm{Po}(6.00 \mathrm{MeV})$ from radon and ${ }^{212} \mathrm{Bi}(6.05 \mathrm{MeV})$ from thoron.

The Alpha- 6 calculates ${ }^{222} \mathrm{Rn}$ concentrations in $\mathrm{pCi} / \mathrm{l}$ and radon and thoron daughter concentrations in milli Working Levels (mWL). The concentrations of Rn daughters ${ }^{222} \mathrm{Rn}$ decay products) varies in the same manner as the ${ }^{222} \mathrm{Rn}$ gas concentrations. These change much more rapidly than the concentration of $\mathrm{Tn}$ daughters $\left({ }^{220} \mathrm{Rn}\right.$ decay products) which are controlled by the 10.6 hour half-life of ${ }^{212} \mathrm{~Pb}$ (see Figure A-23). Although ${ }^{228} \mathrm{Th}$ was not used in this cell, 
it is presently used in cell A-3 and has been used in cell A-4 (see Figure 1). The Tn daughters that were measured by the Alpha- 6 are the result of the ${ }^{220} \mathrm{Rn}$ concentrations in the A cell cave area.

During the final decontamination of cell A-1, an air sampling tube was inserted into the cell to sample the air for both radon $\left({ }^{222} \mathrm{Rn}\right)$ and thoron $\left({ }^{220} \mathrm{Rn}\right)$. The radon and thoron in the cell was $\sim 1 \mathrm{pCi} / 1$ from April 5, 1995 through May 22, 1995 (see Figure A-24). The radon concentrations vary with humidity as measured by the weather station on the main floor of the Shielded Cave Complex. The symbols mark the 6:00 AM measurements for both the humidity and the radon concentrations. The Alpha- 6 monitor was used to measure radon air samples on June 22 and 23, 1995.

\section{Cell Decontamination Summary}

This cell is intended to be left without further decontamination. Future users will have the option of either fixing the residual contamination before use, or attempting further decontamination with more aggressive methods. The identity and quantities of the radionuclides that remain in the cell were estimated from the direct alpha activities and the removable betagamma activities. As a conservative estimate, the direct/removable $\beta \gamma$ activity ratio was assumed to be the same as the direct/removable $\alpha$ activity ratio. These estimates are presented in Table 2. The beta-gamma contamination is assumed to be ${ }^{1 / 2}{ }^{90} \mathrm{Sr}$ and ${ }^{1 / 2}{ }^{90} \mathrm{Y}$. The activity

Table 2. Surface Contamination in Cell A-1

\begin{tabular}{|cc|rr|rr|}
\hline Location & Area & \multicolumn{2}{|c|}{ Alpha Contamination } & \multicolumn{3}{|c|}{ Beta-Gamma Contamination } \\
& $\left(\mathrm{m}^{2}\right)$ & dis $/ \mathrm{min} / \mathrm{m}^{2}$ & $\mathrm{mCi}$ & $\mathrm{dis} / \mathrm{min} / \mathrm{m}^{2}$ & $\mathrm{mCi}$ \\
\hline \hline South & 7 & $12,400,000$ & 0.039 & $434,000,000$ & 1.37 \\
North & 7 & $5,100,000$ & 0.016 & $1,448,000,000$ & 4.57 \\
East & 7 & $1,500,000$ & 0.005 & $40,300,000$ & 0.13 \\
West & 7 & $13,600,000$ & 0.043 & $721,000,000$ & 2.27 \\
Floor & 4 & $\underline{10,300,000}$ & $\underline{0.019}$ & $\underline{1,234,000,000}$ & $\underline{2.22}$ \\
Total & 32 & $42,900,000$ & $\underline{0.122}$ & $3,877,300,000$ & 10.56 \\
\hline
\end{tabular}

is compared to the Nuclear Facility Category III quantities in Table 3. The estimated total alpha 
March 1996

activity is assigned to each of the three radionuclides that were in the Zion Fuel. The ratio of the activity to the Category III quantity indicates that ${ }^{239} \mathrm{Pu}$ is the most restrictive radionuclide. The total activity is $<0.06 \%$ of the Category III level.

Table 3. Contamination in Cell A-1 by Isotope

\begin{tabular}{|cc|r|cc|}
\hline Radionuclide & $\begin{array}{r}\text { Category III } \\
\mathrm{mCi}\end{array}$ & \multicolumn{2}{|c|}{ Cell Activity } \\
& $\mathrm{mCi}$ & \multicolumn{1}{c|}{ Ratio } \\
\hline \hline${ }^{90} \mathrm{Sr}$ & $\beta$ & 16,000 & 5.3 & $3.3 \times 10^{-4}$ \\
${ }^{90} \mathrm{Y}$ & $\beta$ & $1,420,000$ & 5.3 & $3.7 \times 10^{-6}$ \\
${ }^{235} \mathrm{U}$ & $\alpha$ & 4,200 & 0.12 & $2.9 \times 10^{-5}$ \\
${ }^{239} \mathrm{Pu}$ & $\alpha$ & 520 & 0.12 & $2.3 \times 10^{-4}$ \\
${ }^{214} \mathrm{Pu}$ & $\alpha$ & 32,000 & 0.12 & $3.8 \times 10^{-6}$ \\
\hline \multicolumn{2}{|c|}{${ }^{\text {Total } \beta}$} & & 10.6 & $3.3 \times 10^{-4}$ \\
Maximum $\alpha$ & & 0.12 & $2.3 \times 10^{-4}$ \\
\multicolumn{2}{|c|}{$\alpha+\beta$} & & 10.7 & $5.6 \times 10^{-4}$ \\
\hline
\end{tabular}

A summary of the hot spots found by the direct surveys are presented in Table 4. Many exposure rates and direct $\alpha$ contamination measurements were above the acceptance goals that are presented in Table 1. Only the north wall had smear results above the acceptance goals. The direct survey results above the acceptance goals are highlighted and bolded.

Table 4. Direct Survey Hot Spot Summary; Cell A-1

\begin{tabular}{|c|c|c|}
\hline Area & $\mathrm{RO}-20 \mathrm{mR} / \mathrm{h} \gamma$ & $\alpha$ dis $/ \min -61 \mathrm{~cm}^{2}$ \\
\hline West Wall & 122.5 to 30 & $1 / 4 \mathrm{k}$ to $1 \mathrm{M}$ \\
\hline North Wall & 2 to 20 & $1 \mathrm{k}$ to $500 \mathrm{k}$ \\
\hline East Wall & none & S5k to 100k \\
\hline South Wall & 3.620 & 3600 to $10 \mathrm{M}$ \\
\hline Floor & 3 to 8 & $10.8 \mathrm{k}$ to $1 \mathrm{Ml}$ \\
\hline
\end{tabular}

At the present time the general exposure rate in the cell is $2.5 \mathrm{mR} / \mathrm{h}$ at $13 / 4$ meter from the walls and floors. At 30 centimeters from each filter the exposure rate is $2 \mathrm{mR} / \mathrm{h}$. Workers who enter the cell need to be aware that they will accumulate low levels of external exposure. PPE and respiratory protection have been used for all work including the final survey. 


\section{CELL K-1}

\section{A. INTTIAL CELL CONDITION}

\section{Spills and Contamination}

In cell $\mathrm{K}-1$ there were several spills that were not completely cleaned up during the POB project. This produced loose contamination and increased the ease with which ${ }^{220} \mathrm{Rn}$ became airborne increasing the total amount of airborne contamination. One spill on the floor had a reading of $1 \mathrm{R} / \mathrm{h}$ one foot from the surface at the beginning of the decontamination effort.

\section{Stack Emissions}

Monitoring of the cell $\mathrm{K}-1$ stack emissions was initiated for ${ }^{129} \mathrm{I},{ }^{85} \mathrm{Kr}$ and ${ }^{220} \mathrm{Rn}$ in October 1984, two months after operation on the fuel rods began. Hot work in cell K-1 began on October 5, 1984. The stack monitoring has continued through the decontamination of the cells. The emissions from cell $\mathrm{K}-1$ peaked at 2,573 $\mathrm{Ci}$ in 1987 after the completion of the work on the fuel rods but during the solidification of the liquid waste and the initial decontamination. The ${ }^{220} \mathrm{Rn}$ emissions decreased to $657 \mathrm{Ci}$ in 1988 but increased to $1,023 \mathrm{Ci}$ in 1990 (see Table 5 and Figure 10) before the start of the decontamination of this cell began in 1992. Figure 11 shows the emissions from 1988 through 1995. At the completion of the decontamination, the monthly emissions for 1995 have been <1\% of the 1990 emissions for the same month (see Table 5).

From the start of the project through 1987, the monthly emissions as seen in Figure 12 were related to the effort inside the cell. However from 1988 through 1995, the emissions peaked in the summer months and were lower in the winter months. The emissions during the summer months (e.g. 140 curies in August 1990) are more than twice the emissions during the winter months (e.g. 30 curies in January 1990 or January 1991). 
Table 5. ${ }^{20}$ Radon Emissions from Cell K-1

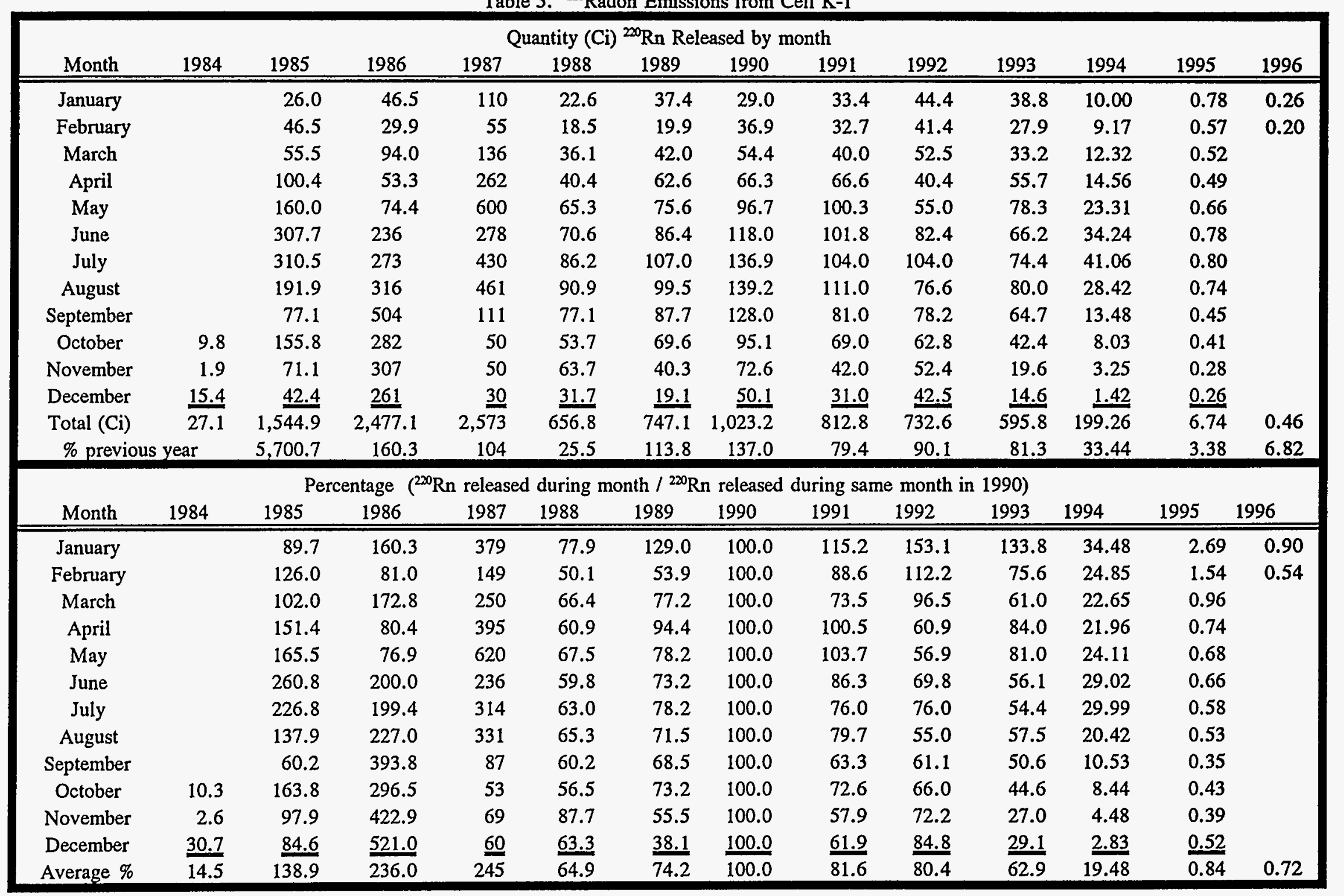


March 1996

\section{B. DECONTAMINATION}

\section{Waste Removed}

Size reduction and clean up of hot spots was performed remotely and waste was packaged in the cell from May 1993 through July 1994. Remote handled waste was removed from this cell during May 1994. Cell entries began during May 1994 to measure the radiation levels. Starting in June 1994, the equipment was disassembled, size reduced, and bagged out. Removal of floor and wall coverings and decontamination of the interior of the cell started in December 1994. The final survey was initiated during March 1995 and it was completed in May 1995.

\section{Accumulated Dose}

The total whole body (deep) dose that was accumulated during the decontamination of cell $\mathrm{K}-1$ was $\sim 2,000$ person-mrem. The total skin (shallow) dose was $\sim 7,100$ person-mrem and the total extremity (ring) dose was $\sim 4,800$ person-mrem. The doses were estimated as $2 / 3$ of those accumulated from May 1994 through August 1994, and 100\% of those accumulated from September 1994 through December 1994. In Figures 7, 8, and 9 it is seen that significant doses were accumulated during this time. Although the final decontamination continued through March 1995, the dose rates during the 1995 work effort in the cell were low and did not contribute to the doses presented above.

\section{Decontamination Limit}

The cells were decontaminated to the paint layer. If there was loose contamination on the paint it was removed. However, no attempt was made to remove contamination under the paint except for the area of the spill on the floor in grid 3 east, 6 north. The other area where additional effort was expended to reduce the contamination was on the north wall near the HEPA filter, grids 3 east, 1 high; 3 east, 2 high; and 4 east, 1 high.

\section{FINAL SURVEY RESULTS}

The values that were measured during the survey are compared to the acceptance goals. For each graph containing the direct survey data, the average grid measurements are presented 
in large numbers in the center of the grid; the elevated readings are presented in smaller numbers at the location of the hot spots. In the legend, the instrument and the corresponding units of the measurements are designated for direct surveys. The smear data is presented as a ratio with the alpha activity printed in the numerator to the beta-gamma activity printed in the denominator. The legend indicates whether the smear covered the large $1 \mathrm{~m}^{2}$ or the small 100 $\mathrm{cm}^{2}$ area near the center of the grid. The layout of cell $\mathrm{K}-1$ is shown in Figure B-1.

\section{K-1 West Wall}

The average grid dose rates ranged from $0.1 \mathrm{mR} / \mathrm{h}$ to $0.5 \mathrm{mR} / \mathrm{h}$. The grids with the crane rails and brackets on the west wall exhibit higher direct radiation levels than the rest of the wall (see Figure B-2). The gamma readings for the rail and brackets were $0.5 \mathrm{mR} / \mathrm{h}$. These readings are below both the average and the maximum exposure rate goals.

The average alpha reading in each grid ranged from $100 \mathrm{dis} / \mathrm{min}$ to $600 \mathrm{dis} / \mathrm{min}$ using a $61 \mathrm{~cm}^{2}$ probe. The direct alpha readings for the crane rails and brackets ranged between $1 \mathrm{k}$ $\mathrm{dis} / \mathrm{min}$ and $60 \mathrm{k} \mathrm{dis} / \mathrm{min}$ (see Figure B-3). These values are above the maximum total $\alpha$ activity goal for $100 \mathrm{~cm}^{2}$. There were also other hot spots that ranged from $160 \mathrm{dis} / \mathrm{min}$ to $5 \mathrm{k} \mathrm{dis} / \mathrm{min}$. Small smears were taken of the three brackets in grids 3 north, 4 high; 4 north, 4 high; and 5 north, 4 high and analyzed for gamma emitting radionuclides. The main radionuclides present were ${ }^{137} \mathrm{Cs}\left(65 \pm 7 \mathrm{dpm}\right.$ to $542 \pm 20 \mathrm{dpm}$ ) and ${ }^{125} \mathrm{Sb}$ ( $21 \pm 11 \mathrm{dpm}$ to $123 \pm 25 \mathrm{dpm}$ ), nuclides that are found in contamination from the $\mathrm{POB}$ project.

The maximum loose activity on the large area smears was $3.4 \mathrm{k} \mathrm{dpm} / 1 \mathrm{~m}^{2} \alpha$ and $190 \mathrm{k}$ $\mathrm{dpm} / 1 \mathrm{~m}^{2} \beta \gamma$, well below the above values (see Figure B-4). The highest removable activity was in a grid at the top of the wall that contained the crane rail and brackets. The highest alpha activity on a small area smear was $55 \mathrm{dpm} / 100 \mathrm{~cm}^{2}$; the highest $\beta \gamma$ activity was $2 \mathrm{kdpm} / 100 \mathrm{~cm}^{2}$ (see Figure B-5). Both are below the maximum removable activity goals.

\section{K-1 North Wall}

The grids around the HEPA filter to the high flow stack on the north wall had average exposure rates on contact between 1.5 and $2.5 \mathrm{mR} / \mathrm{h}$; for all other grids, the average exposure 
rates were between $0.1 \mathrm{mR} / \mathrm{h}$ and $1.0 \mathrm{mR} / \mathrm{h}$ (see Figure B-6). All are below their respective average contact exposure rate goals. The maximum exposure rates ranged from $0.5 \mathrm{mR} / \mathrm{h}$ to $3 \mathrm{mR} / \mathrm{h}$ on the lights and around the viewing window, to a maximum of $10 \mathrm{mR} / \mathrm{h}$ around the HEPA filter housing; below the respective maximum contact exposure rate goals. At $30 \mathrm{~cm}$ from the filter, the exposure rate decreased to $0.5 \mathrm{mR} / \mathrm{h}$.

The average alpha readings in each grid range from $50 \mathrm{dis} / \mathrm{min}$ to $600 \mathrm{dis} / \mathrm{min}$ using a $61 \mathrm{~cm}^{2}$ probe except in two of the grids that contain the HEPA filter that had average readings of $1 \mathrm{k} \mathrm{dis} / \mathrm{min}$ and $5 \mathrm{k} \mathrm{dis} / \mathrm{min}$ (see Figure B-7). The hot spots range from $900 \mathrm{dis} / \mathrm{min}$ to $600 \mathrm{k}$ dis/min. Although most the grid averages are below the acceptance goal, most of the hot spots on this wall exceed the acceptance goals. The HEPA filter housing has the highest reading. There is also high residual activity in grid 3 east, 2 high that is the result of a spill.

The maximum loose activity on a large area smear was $2.3 \mathrm{k} \mathrm{dpm} / 1 \mathrm{~m}^{2} \alpha$ and $82 \mathrm{k} \mathrm{dpm} / 1$ $\mathrm{m}^{2} \beta \gamma$, well below the average acceptance goals (see Figure B-8). The largest removable activity was again in grid 3 east, 2 high that had the spill. The highest alpha activity on a small area smear was $430 \mathrm{dpm} / 100 \mathrm{~cm}^{2}$; the highest $\beta \gamma$ activity was $13 \mathrm{kdpm} / 100 \mathrm{~cm}^{2}$ (see Figure B9). Both are above the maximum removable acceptance goals.

\section{K-1 East Wall}

The average gamma readings on the east wall were between 0.3 to $5.0 \mathrm{mR} / \mathrm{h}$ (see Figure B-10). The measurements that are above the average exposure rates on contact were in the bottom two rows. The exposure rates ranged from $1.5 \mathrm{mR} / \mathrm{h}$ to $25 \mathrm{mR} / \mathrm{h}$. Several hot spots around the viewing ports do not meet the acceptance goals nor does the area opposite the filter bank on the south wall.

The average alpha readings in each grid range from $100 \mathrm{dis} / \mathrm{min}$ to $1 \mathrm{k} \mathrm{dis} / \mathrm{min}$ using a $61 \mathrm{~cm}^{2}$ probe (see Figure B-11). All of these values except the $1 \mathrm{k}$ dis/min in grid 4 north, 1 high were below the average total alpha activity acceptance goal. The direct alpha readings for the hot spots were between $500 \mathrm{dis} / \mathrm{min}$ and $200 \mathrm{k} \mathrm{dis} / \mathrm{min}$ using a $61 \mathrm{~cm}^{2}$ probe. Most of these values are above the maximum total $\alpha$ activity acceptance goal for a $100 \mathrm{~cm}^{2}$ area. The hot spots were along the crane rail and brackets, around the viewing ports, on the light fixtures, on 
March 1996

the pipe, and in the manipulator ports.

The maximum loose activity on a large area smear was $730 \mathrm{dpm} / 1 \mathrm{~m}^{2} \alpha$ and $78 \mathrm{k} \mathrm{dpm} / 1$ $\mathrm{m}^{2} \beta \gamma$, well below the average removable alpha activity acceptance goal (see Figure B-12). The largest removable alpha activity was in grid 4 north, 2 high that contained a viewing port. The largest removable beta activity was in grid 3 north, 3 high that contained the section of piping with a high direct alpha reading. The highest alpha activity on a small area smear was 320 $\mathrm{dpm} / 100 \mathrm{~cm}^{2}$; the highest $\beta \gamma$ activity was $3.6 \mathrm{k} \mathrm{dpm} / 100 \mathrm{~cm}^{2}$ (see Figure B-13). Both are below the maximum removable activity acceptance goals.

\section{K-1 South Walls and Door}

The south wall has many sections including the door. Although some of these sections are actually facing east and west, for this report they will be considered as part of the south wall. The average gamma readings were between 0.2 to $0.7 \mathrm{mR} / \mathrm{h}$ except behind the low flow filter ducts in grids (east 3,4 and 5, and the bottom 2 rows) where the readings are up to 4 $\mathrm{mR} / \mathrm{h}$ (see Figure B-14). These measurements are below the average contact exposure rate goals. The hot spots ranged from $0.5 \mathrm{mR} / \mathrm{h}$ to $4 \mathrm{mR} / \mathrm{h}$ except by the HEPA filters where the exposure rate was up to $10 \mathrm{mR} / \mathrm{h}$. At $30 \mathrm{~cm}$ from the filters, the exposure rate decreased to 2 $\mathrm{mR} / \mathrm{h}$. The hot spots are below the respective maximum contact exposure rate goals.

The average alpha readings in each grid range from $100 \mathrm{dis} / \mathrm{min}$ to $1.2 \mathrm{k} \mathrm{dis} / \mathrm{min}$ using a $61 \mathrm{~cm}^{2}$ probe (see Figure B-15). All of these values except the $1.2 \mathrm{k}$ dis/min reading behind the HEPA filters were below the average total alpha activity acceptance goal for $100 \mathrm{~cm}^{2}$. The direct alpha readings for the hot spots were between $400 \mathrm{dis} / \mathrm{min}$ and $180 \mathrm{k} \mathrm{dis} / \mathrm{min}$ using a 61 $\mathrm{cm}^{2}$ probe. Most of these values are above the maximum total $\alpha$ activity acceptance goal for $100 \mathrm{~cm}^{2}$. The hot spots were on lights, a switch and along the bottom of the door.

The maximum loose activity on a large area smear was $3.5 \mathrm{k} \mathrm{dpm} / 1 \mathrm{~m}^{2} \alpha$ and $180 \mathrm{kdpm} / 1$ $\mathrm{m}^{2} \beta \gamma$, well below the average removable acceptance goals (see Figure B-16). The largest removable activity was in grid 4 east, 1 high behind the HEPA filters. The highest alpha activity on a small area smear was $300 \mathrm{dpm} / 100 \mathrm{~cm}^{2}$; the highest $\beta \gamma$ activity was $7 \mathrm{k} \mathrm{dpm} / 100$ $\mathrm{cm}^{2}$ (see Figure B-17). Both are below the maximum removable activity acceptance goals. 


\section{K-1 Floor}

The average gamma readings on the cell floor were between 0.3 to $1.5 \mathrm{mR} / \mathrm{h}$ (see Figure B-18). The high measurements are below the HEPA filters on the north and south walls and in grid 3 east, 5 north that contained a spill. Except for the spill, these measurements are below the average contact exposure rate acceptance goals. The hot spots ranged from $0.5 \mathrm{mR} / \mathrm{h}$ to 1.5 $\mathrm{mR} / \mathrm{h}$ in the rails for the mule and up to $4 \mathrm{mR} / \mathrm{h}$ below the south HEPA filter bank (duct space). The spill still had a direct reading of $3.5 \mathrm{mR} / \mathrm{h}$. The hot spots are below the maximum contact exposure rate acceptance goals. The general exposure rate a $13 / 4$ meter above the floor was 0.5 $\mathrm{mR} / \mathrm{h}$.

The average alpha readings in each grid range from $200 \mathrm{dis} / \mathrm{min}$ to $400 \mathrm{k}$ dis $/ \mathrm{min}$ using a $61 \mathrm{~cm}^{2}$ probe (see Figure B-19). The average total activities on the grids that had the spill (3 east, 5 north and 3 east, 6 north) and row of grids 4 east and 5 east are above the $1 \mathrm{k} \mathrm{dis} / \mathrm{min}$ acceptance goal. The direct alpha readings for the hot spots were between $500 \mathrm{dis} / \mathrm{min}$ and $>1 \mathrm{M}$ dis/min using a $61 \mathrm{~cm}^{2}$ probe. Most of these values are above the maximum total $\alpha$ activity acceptance goal for $100 \mathrm{~cm}^{2}$. The hot spots were in the mule rails, and scattered over most of the floor including the areas of the spill.

The maximum loose activity on a large area smear was $4.7 \mathrm{k} \mathrm{dpm} / 1 \mathrm{~m}^{2} \alpha$ and $600 \mathrm{k} \mathrm{dpm} / 1$ $\mathrm{m}^{2} \beta \gamma$, well below the average removable activity acceptance goals (see Figure B-20). The highest removable activity was in grid 3 east, 6 north the location of the spill. The smears in the mule rails are presented on the graph with the data for the $100 \mathrm{~cm}^{2}$ data (see Figure B-21). The loose activity in the rails ranged from $280 \mathrm{dpm}$ to $1.7 \mathrm{k} \mathrm{dpm} \alpha$ and from $12 \mathrm{k} \mathrm{dpm}$ to $28 \mathrm{k}$ $\operatorname{dpm} \beta \gamma$. Although the loose alpha activity in the rails is above the maximum removable acceptance goal for $100 \mathrm{~cm}^{2}$, the beta-gamma activity is below the maximum removable acceptance goals. The highest alpha activity on the other small area smears was $550 \mathrm{dpm} / 100$ $\mathrm{cm}^{2}$; the highest $\beta \gamma$ activity was $1 \mathrm{M} \mathrm{dpm} / 100 \mathrm{~cm}^{2}$. The alpha activities are below the maximum removable acceptance goal however, one smear below the HEPA filters on the south wall had a $\beta \gamma$ activity that was above the maximum acceptance goal. 
Verification Survey of

Building 200 Hot Cells

March 1996

\section{K-1 Overhead}

The only overhead equipment that was surveyed was the one ton capacity bridge crane. All of the gamma readings were $0.1 \mathrm{mR} / \mathrm{h}$ (see Figure B-22). The direct alpha readings range from $3 \mathrm{k} \mathrm{dis} / \mathrm{min}$ to $30 \mathrm{k}$ dis $/ \mathrm{min}$ using a $61 \mathrm{~cm}^{2}$ probe. These values are above the maximum total alpha activity acceptance goal for $100 \mathrm{~cm}^{2}$. In some sections the direct alpha readings were measured on each side of the I-beam that supports the crane.

The maximum loose activity on large area smears was $9.3 \mathrm{k} \mathrm{dpm} / 1 \mathrm{~m}^{2} \alpha$ and $320 \mathrm{k} \mathrm{dpm} / 1$ $\mathrm{m}^{2} \beta \gamma$, well below the average removable acceptance goals. No $100 \mathrm{~cm}^{2}$ smears were taken.

\section{CONCLUSIONS}

\section{Measurements of Residual Radon Gas}

As a result of the residual contamination from the $\mathrm{POB}$ project, thoron is present in the cell and it is emitted from the stacks. The amount of thoron and naturally occurring radon were measured by two monitors, an RGM-2 and an Alpha- 6 . The Alpha- 6 measured the energy of the alpha particle and generated the spectrum seen in Figure B-23. Three prominent peaks are seen; one, ${ }^{212} \mathrm{Po}(8.78 \mathrm{MeV})$, from thoron; one, ${ }^{214} \mathrm{Po}(7.69 \mathrm{MeV})$, from radon; and one from a combination of ${ }^{218} \mathrm{Po}(6.00 \mathrm{MeV})$ from radon and ${ }^{212} \mathrm{Bi}(6.05 \mathrm{MeV})$ from thoron.

The Alpha-6 calculates ${ }^{222} \mathrm{Rn}$ concentrations in $\mathrm{pCi} / 1$ and radon and thoron daughter concentrations in milli Working Levels (mWL). The concentrations of decay products in the air from ${ }^{222} \mathrm{Rn}$ is much less than the concentration of decay products from ${ }^{220} \mathrm{Rn}$ (see Figure B24). The $\mathrm{Rn}$ daughter concentration changes much more rapidly than the $\mathrm{Tn}$ daughter concentration which is controlled by the 10.6 hour half-life of ${ }^{212} \mathrm{~Pb}$. The Tn daughter activity is 1.3 to 3 times the Rn daughter activity.

During the final decontamination of cell $\mathrm{K}-1$, an air sampling tube was inserted into the cell to sample the air for ${ }^{220} \mathrm{Rn}$. The air sample was measured on an RGM-2 monitor. The ${ }^{220} \mathrm{Rn}$ activity in the cell was $\sim 10 \mathrm{pCi} / 1$ except during spray painting and scrubbing when it rose to $\sim 40 \mathrm{pCi} / 1$ (see Figure B-25). At the same time the stack emissions ranged from $200 \mathrm{pCi} / 1$ to $400 \mathrm{pCi} / 1$ from the high flow stack, and from $300 \mathrm{pCi} / 1$ to $800 \mathrm{pCi} / 1$ from the low flow stack. It is assumed that the difference between the stack measurements and the cell measurements is 
due to residual contamination in the air ducts and on the HEPA filters in the fan loft. These were not intended to be changed as part of this decontamination project.

\section{Cell Decontamination Summary}

The cell is intended to be left without further decontamination. The identity and quantities of radionuclides that remain in the cell were estimated from the stack emissions. Since the stack emissions are so much greater than the cell concentrations, it was assumed that all the gas released from the stack was entirely ${ }^{220} \mathrm{Rn}$ and its daughters. The estimates as

Table 6. Isotopes in Cell K-1 from Stack Emissions

\begin{tabular}{|c|c|c|c|c|}
\hline \multicolumn{2}{|c|}{ Radionuclide } & \multirow{2}{*}{$\begin{array}{l}\begin{array}{l}\text { Cat III } \\
\text { mCi }\end{array} \\
60,000\end{array}$} & \multirow{2}{*}{$\frac{\begin{array}{c}\text { Activity } \\
\mathrm{mCi}\end{array}}{4.2}$} & \multirow{2}{*}{$\frac{\text { Ratio }}{7.1 \times 10^{-5}}$} \\
\hline${ }^{137} \mathrm{Cs}$ & $\beta$ & & & \\
\hline${ }^{90} \mathrm{Sr}$ & $\beta$ & 16,000 & 4.2 & $2.6 \times 10^{-4}$ \\
\hline${ }^{90} \mathrm{Y}$ & $\beta$ & $1,420,000$ & 4.2 & $3.0 \times 10^{-6}$ \\
\hline${ }^{125} \mathrm{Sb}$ & $\beta$ & $1,200,000$ & 0.34 & $2.8 \times 10^{-7}$ \\
\hline${ }^{134} \mathrm{Cs}$ & $\beta$ & 42,000 & 0.16 & $3.8 \times 10^{-6}$ \\
\hline${ }^{154} \mathrm{Eu}$ & $\beta$ & 200,000 & 0.052 & $2.6 \times 10^{-7}$ \\
\hline${ }^{155} \mathrm{Eu}$ & $\beta$ & 940,000 & 0.010 & $1.1 \times 10^{-8}$ \\
\hline${ }^{232} \mathrm{Th}$ & $\alpha$ & 100 & $<0.00001$ & $2.4 \times 10^{-8}$ \\
\hline${ }^{233} \mathrm{U}$ & $\alpha$ & 4,200 & 0.0071 & $1.7 \times 10^{-6}$ \\
\hline${ }^{232} \mathrm{U}$ & $\alpha$ & 820 & 0.021 & $2.6 \times 10^{-5}$ \\
\hline${ }^{228} \mathrm{Th}$ & $\alpha$ & 1,000 & 0.021 & $2.1 \times 10^{-5}$ \\
\hline${ }^{224} \mathrm{Ra}$ & $\alpha$ & 200,000 & 0.021 & $1.1 \times 10^{-7}$ \\
\hline${ }^{220} \mathrm{Rn}$ & $\alpha$ & 2,000 & 0.021 & $1.1 \times 10^{-5}$ \\
\hline${ }^{216} \mathrm{Po}$ & $\alpha$ & & 0.021 & \\
\hline${ }^{212} \mathrm{~Pb}$ & $\beta$ & $3,200,000$ & 0.021 & $6.6 \times 10^{-9}$ \\
\hline${ }^{212} \mathrm{Bi}$ & $\alpha, \beta$ & & 0.021 & \\
\hline${ }^{212} \mathrm{Po}$ & $\alpha$ & & 0.021 & \\
\hline${ }^{208} \mathrm{Tl}$ & $\beta$ & & 0.021 & \\
\hline \multicolumn{2}{|c|}{ Total o } & & 0.14 & $5.9 \times 10^{-5}$ \\
\hline \multicolumn{2}{|c|}{ Total $\beta$} & & 13.3 & $3.4 \times 10^{-4}$ \\
\hline \multicolumn{2}{|c|}{ Total $\alpha+\beta$} & & 13.4 & $4.0 \times 10^{-4}$ \\
\hline
\end{tabular}


March 1996

presented in Table 6 are based on the emissions after the HEPA filters were changed in the fan loft on February 16, 1996. The discharge rate before the filters were changed was $\sim 6 \mu \mathrm{Ci} / \mathrm{min}$; and $\sim 3.5 \mu \mathrm{Ci} /$ min after they were changed (see Figure 26 ). The radionuclides listed above ${ }^{232} \mathrm{U}$ are estimated from analyses of smear at the start of the D\&D project. These activities are compared to the Nuclear Facility Category III quantities. As seen at the bottom of the table, the sum of the ratios is $\leq 0.04 \%$ of the Category III level.

A summary of the hot spots found by the direct surveys are presented in Table 7. Direct $\alpha$ contamination measurements on each wall, floor or overhead were above the acceptance goals that are presented in Table 1. The east wall had direct $\gamma$ readings above the acceptance goals. The floor had small area smears greater than the acceptance goal. The direct survey results above the acceptance goals are highlighted and bolded.

Table 7. Direct Survey Hot Spot Summary; Cell K-1

\begin{tabular}{|c|c|c|}
\hline Area & $\mathrm{RO}-20 \mathrm{mR} / \mathrm{h} \gamma$ & $\alpha$ dis $/ \min -61 \mathrm{~cm}^{2}$ \\
\hline West Wall & 0.5 & 3160 to 600 \\
\hline North Wall & 0.5 to 10 & 0.900 to $600 \mathrm{k}$ \\
\hline East Wall & 415 to 25 & $8500 \mathrm{lo} 200 \mathrm{k}$ \\
\hline South Wall & 0.5 to 10 & 4400 to $180 \mathrm{k}$ \\
\hline Floor & 0.5 to 4 & 500 to $>1 \mathrm{NA}$ \\
\hline Crane & none & $13 \mathrm{~K}$ to $30 \mathrm{k}$ \\
\hline
\end{tabular}

At the present time the general exposure rate at $13 / 4$ meter from the walls and floors is $0.5 \mathrm{mR} / \mathrm{h}$. The exposure rate at 30 centimeters from the high flow filter on the north wall was also $0.5 \mathrm{mR} / \mathrm{h}$. However, the exposure rate at 30 centimeters from the low flow filters on the south wall was $2 \mathrm{mR} / \mathrm{h}$. Workers can enter the cell without concern for external exposure. Some level PPE would be required depending upon the intended work.

\section{Stack Emissions}

Before the decontamination project began, the discharge rate of the air from the $\mathrm{K}-1$ stacks ranged from $300 \mu \mathrm{Ci} / \mathrm{min}$ to $4,000 \mu \mathrm{Ci} / \mathrm{min}$ as seen in Figure B-26, that presents the values from February 1992 through February 1993. During the final stages of the decontami- 
nation project, the discharge of the air from the $\mathrm{K}-1$ stacks ranged from $5 \mu \mathrm{Ci} / \mathrm{min}$ to 30 $\mu \mathrm{Ci} / \mathrm{min}$ from February 1995 through January 1996. After the HEPA filters in the fan loft were changed, the discharge rate ranged from $2.5 \mu \mathrm{Ci} / \mathrm{min}$ to $3.5 \mu \mathrm{Ci} / \mathrm{min}$ in February and March 1996. From March through June 1995 when the humidity increased, the stack discharge rate remained below $30 \mu \mathrm{Ci} / \mathrm{min}$. Since the flow rate through the filters does not change significantly during the year, the discharge rate reflects the radon concentration in the stack gas.

The peak year for emissions since 1987 was 1990 (1,023 Ci). In 1992 the yearly emissions were less than in 1990. In 1995 there were $6.7 \mathrm{Ci}$ emitted $0.6 \%$ of the 1990 value or $0.8 \%$ of the 1991 value (see Table 5 and Figure 11). In 1995 the emissions decreased in April and May with respect to the previous months. In Figure 12 it can be seen that this is very unusual. The pre-filters in the cell were changed at the end of February 1995 and the final scrubbing of cell $\mathrm{K}-1$ was performed during the beginning of March. 


\section{CELL K-3}

\section{A. INITIAL CELL CONDITION}

\section{Spills and Contamination}

In cell K-3 there were no known spills. There was some loose contamination but little airborne contamination. In 1991 a ${ }^{231} \mathrm{~Pa}$ source was repackaged in this cell. Smears from the cell at the start of the $\mathrm{D} \& \mathrm{D}$ project did not detect ${ }^{231} \mathrm{~Pa}$ contamination.

\section{Stack Emissions}

Monitoring of the cell K-3 stack emissions was initiated in January 1984 for ${ }^{129} \mathrm{I}$ and ${ }^{220} \mathrm{Rn}$. Because the emissions from this cell were low after the conclusion of the project, the pumps for the stack monitors were removed on March 3, 1986. Starting in 1991 the stack concentration and flow rate were measured semi-annually. This practice has continued through the decontamination of the cells. The emissions from cell $\mathrm{K}-3$ were at their maximum during June and August 1985 (see Table 8 and Figure 12). The monthly emissions were less than $4 \mathrm{Ci}$ during the operation on the fuel rods in 1984 and 1985. Before the cell was decontaminated, the estimated monthly emissions were less than $2 \mathrm{Ci}$ from 1991 through 1993. Since the cell decontamination has been completed, the estimated monthly emissions have been less than 0.2 Ci.

The estimated quarterly and yearly emissions are presented in Figure 13. During 1985 the emissions were much greater than in 1984. The decontamination effort has reduced the 1995 emissions to $\sim 9 \%$ of the 1993 emissions or $20 \%$ of the 1991 emissions. The current 1996 emission estimates are $\sim 9 \%$ of the 1991 emission estimate.

\section{B. DECONTAMINATION}

\section{Waste Removed}

Cell K-3 was remotely cleaned and waste was remotely packaged in the cell starting during October 1993. The entry tent was constructed during December 1993. Cell entries 
Table 8. ${ }^{220}$ Radon Emissions from Cell K-3

\begin{tabular}{|c|c|c|c|c|c|c|c|c|c|c|c|c|c|}
\hline \multicolumn{14}{|c|}{ Quantity (Ci) ${ }^{220} \mathrm{Rn}$ Released by month } \\
\hline Month & 1984 & 1985 & 1986 & 1987 & 1988 & 1989 & 1990 & 1991 & 1992 & 1993 & 1994 & 1995 & 1996 \\
\hline January & 0.108 & 0.2 & 0.17 & & & & & 0.70 & 1.19 & 1.19 & 1.17 & 0.17 & 0.06 \\
\hline February & 0.027 & 0.2 & & & & & & 0.70 & 1.19 & 1.19 & 0.09 & 0.15 & 0.06 \\
\hline March & 0.027 & 0.6 & & & & & & 0.70 & 1.19 & 1.19 & 0.10 & 0.17 & \\
\hline April & 0.015 & 0.5 & & & & & & 0.70 & 1.19 & 1.77 & 0.10 & 0.16 & \\
\hline May & 0.023 & 0.5 & & & & & & 0.70 & 1.19 & 1.83 & 0.09 & 0.13 & \\
\hline June & 0.034 & 3.3 & & & & & & 0.70 & 1.19 & 1.77 & 0.09 & 0.13 & \\
\hline July & 0.024 & 1.1 & & & & & & 0.70 & 1.19 & 1.83 & 0.09 & 0.13 & \\
\hline August & 0.185 & 3.8 & & & & & & 0.70 & 1.19 & 1.83 & 0.09 & 0.13 & \\
\hline September & 0.60 & 1.6 & & & & & & 0.70 & 1.19 & 1.77 & 0.09 & 0.13 & \\
\hline October & 0.40 & .8 & & & & & & 0.70 & 1.19 & 1.83 & 0.17 & 0.13 & \\
\hline November & 0.05 & .6 & & & & & & 0.70 & 1.19 & 1.14 & 0.16 & 0.13 & \\
\hline December & $\underline{0.75}$ & .3 & & & & & & $\underline{0.70}$ & $\underline{1.19}$ & $\underline{1.17}$ & $\underline{0.17}$ & $\underline{0.13}$ & \\
\hline Total (Ci) & 2.243 & 13.50 & 0.17 & 0.00 & 0.00 & 0.00 & 0.00 & $\overline{8.40}$ & $\overline{14.28}$ & $1 \overline{8.51}$ & 2.41 & $\overline{1.69}$ & 0.12 \\
\hline \multicolumn{2}{|c|}{$\%$ previous year } & 601.87 & & & & & & & 170.00 & 129.62 & 13.02 & 70.12 & 7.10 \\
\hline \multicolumn{14}{|c|}{ Percentage $\left({ }^{220} \mathrm{Rn}\right.$ released during month $/{ }^{220} \mathrm{Rn}$ released during same month in 1992$)$} \\
\hline Month & 1984 & 1985 & 1986 & 1987 & 1988 & 1989 & 1990 & 1991 & 1992 & 1993 & 1994 & 1995 & 1996 \\
\hline January & 9.080 & 16.81 & 14.29 & & & & & 58.82 & 100.00 & 100.00 & 98.32 & 14.29 & $\overline{5.04}$ \\
\hline February & 2.270 & 16.81 & & & & & & 58.82 & 100.00 & 100.00 & 7.56 & 12.61 & 5.04 \\
\hline March & 2.270 & 50.42 & & & & & & 58.82 & 100.00 & $: 00.00$ & 8.40 & 14.29 & \\
\hline April & 1.260 & 42.02 & & & & & & 58.82 & 100.00 & 148.74 & 8.40 & 13.45 & \\
\hline May & 1.930 & 42.02 & & & & & & 58.82 & 100.00 & 153.78 & 7.56 & 10.92 & \\
\hline June & 2.860 & 277.31 & & & & & & 58.82 & 100.00 & 148.74 & 7.56 & 10.92 & \\
\hline July & 2.020 & 92.44 & & & & & & 58.82 & 100.00 & 153.78 & 7.56 & 10.92 & \\
\hline August & 15.550 & 319.33 & & & & & & 58.82 & 100.00 & 153.78 & 7.56 & 10.92 & \\
\hline September & 50.420 & 134.45 & & & & & & 58.82 & 100.00 & 148.74 & 7.56 & 10.92 & \\
\hline October & 33.610 & 67.23 & & & & & & 58.82 & 100.00 & 153.78 & 14.29 & 10.92 & \\
\hline November & 4.200 & 50.42 & & & & & & 58.82 & 100.00 & 95.80 & 13.45 & 10.92 & \\
\hline December & 63.030 & 25.21 & & & & & & $\underline{58.82}$ & 100.00 & 98.32 & 14.29 & 10.92 & \\
\hline Average \% & 15.708 & 94.54 & 14.29 & 0.00 & 0.00 & 0.00 & 0.00 & 58.82 & 100.00 & 129.62 & 16.88 & 11.83 & 5.04 \\
\hline
\end{tabular}


began during January 1994 and were competed during March 1994. The final release survey was performed during June 1995.

\section{Accumulated Dose}

The total whole body (deep) dose that was accumulated during the decontamination of cell K-3 was $\sim 40$ person-mrem (see Figure 7). The total skin (shallow) dose was $\sim 300$ person-mrem (see Figure 20 ) and the total extremity (ring) dose was $\sim 370$ person-mrem (see Figure 21). The doses were estimated as $1 / 4$ of those accumulated in December 1993 and 100\% of those accumulated from January through March 1994. Although initial entries were made at the end of November, the November and December doses were mainly due to the movement of drums from cell $M-4$ to cell $M-3$ and repackaging these drums.

\section{Decontamination Limit}

The cells were decontaminated to the paint layer. Numerous attempts were made to remove loose contamination that was on the paint. However, no attempt was made to remove the paint or the contamination under the paint.

\section{FINAL SURVEY RESULTS}

The values that were measured during the survey are compared to the acceptance goals. For each graph containing the direct survey data, the average grid measurements are presented in large numbers in the center of the grid; the elevated readings are presented in smaller numbers at the location of the hot spots. In the legend, the instrument and the corresponding units of the measurements are designated for direct surveys. The smear data is presented as a ratio with the alpha activity printed in the numerator to the beta-gamma activity printed in the denominator. The legend indicates whether the smear covered the large $1 \mathrm{~m}^{2}$ or the small 100 $\mathrm{cm}^{2}$ area near the center of the grid. The layout of cell K-3 is shown in Figure C-1. 


\section{K-3 West Wall}

The filter housing on the west wall exhibits higher direct radiation levels $(0.5 \mathrm{mR} / \mathrm{h})$ than the rest of the wall (see Figure $\mathrm{C}-2$ ). In general the gamma readings were $0.1 \mathrm{mR} / \mathrm{h}$. The highest reading was below both the average and the maximum exposure rate goals on contact.

The average alpha readings in each grid ranged from $100 \mathrm{dis} / \mathrm{min}$ to $500 \mathrm{dis} / \mathrm{min}$ using a $61 \mathrm{~cm}^{2}$ probe. All of these values are below the average alpha activity acceptance goal for 100 $\mathrm{cm}^{2}$. The direct alpha readings of the hot spots ranged between $1.5 \mathrm{k}$ dis $/ \mathrm{min}$ and $50 \mathrm{k}$ dis $/ \mathrm{min}$ using a $61 \mathrm{~cm}^{2}$ probe (see figure $\mathrm{C}-3$ ). All except the $1.5 \mathrm{k}$ value were above the maximum total $\alpha$ activity acceptance goal for $100 \mathrm{~cm}^{2}$.

The maximum loose activity on large area smears was $110 \mathrm{dpm} / 1 \mathrm{~m}^{2} \alpha$ and $4.6 \mathrm{k} \mathrm{dpm} / 1$ $\mathrm{m}^{2} \beta \gamma$, well below the Table 1 values (see Figure C-4). The highest removable activity was in the grid between the windows containing part of the south window. The highest alpha activity on a small area smear was $50 \mathrm{dpm} / 100 \mathrm{~cm}^{2}$; the highest $\beta \gamma$ activity was $1.4 \mathrm{kdpm} / 100 \mathrm{~cm}^{2}$ (see Figure $\mathrm{C}-5$ ). Both are below the maximum removable activity goals.

\section{K-3 North Wall}

The HEPA filter to the high flow stack had an exposure rate of $0.5 \mathrm{mR} / \mathrm{h}$; for all grids, the average exposure rate was $0.1 \mathrm{mR} / \mathrm{h}$ (see Figure $\mathrm{C}-6$ ). At $30 \mathrm{~cm}$ from the filter, the exposure rate decreased to $0.2 \mathrm{mR} / \mathrm{h}$. All measurements were below the average contact exposure rate goal.

The average alpha readings in each grid range from $100 \mathrm{dis} / \mathrm{min}$ to $400 \mathrm{dis} / \mathrm{min}$ using a $61 \mathrm{~cm}^{2}$ probe (see Figure C-7). The hot spots range from $1.2 \mathrm{k} \mathrm{dis} / \mathrm{min}$ to $50 \mathrm{k} \mathrm{dis} / \mathrm{min}$. All of the grid averages are below the acceptance goal. Most of the hot spots on this wall exceed the acceptance goals. The transfer lock has the highest reading.

The maximum loose activity on large area smears was $430 \mathrm{dpm} / 1 \mathrm{~m}^{2} \alpha$ and $5.2 \mathrm{kdpm} / 1$ $\mathrm{m}^{2} \beta \gamma$ in the upper left grid (see Figure $\mathrm{C}-8$ ). These values are well below the average acceptance goals. The highest alpha activity on a small area smear was $70 \mathrm{dpm} / 100 \mathrm{~cm}^{2}$; the highest $\beta \gamma$ activity was $560 \mathrm{dpm} / 100 \mathrm{~cm}^{2}$ (see Figure C-9). Both are well below the maximum removable acceptance goals. 


\section{K-3 East Walls and Door}

The east wall has many sections including the recess for the low flow HEPA filter and the door. Although some of these sections is actually facing south and north, for this report they will be considered as part of the east wall. The average gamma readings on the east wall were $0.1 \mathrm{mR} / \mathrm{h}$ (see Figure $\mathrm{C}-10$ ). The measurements that are above the average exposure rates on contact were either on the low flow HEPA filter housing, $0.5 \mathrm{mR} / \mathrm{h}$, or on pipes, $0.4 \mathrm{mR} / \mathrm{h}$ and $0.7 \mathrm{mR} / \mathrm{h}$. These hot spots meet the maximum contact exposure rate acceptance goal. At 30 $\mathrm{cm}$ from the HEPA filters, the exposure rate decreased to $0.1 \mathrm{mR} / \mathrm{h}$.

The average alpha readings in each grid range from $100 \mathrm{dis} / \mathrm{min}$ to $500 \mathrm{dis} / \mathrm{min}$ using a $61 \mathrm{~cm}^{2}$ probe (see Figure C-11). All of these values were below the average total alpha activity acceptance goal. The direct alpha readings for the hot spots were between $6 \mathrm{k} \mathrm{dis} / \mathrm{min}$ and $90 \mathrm{k}$ dis/min using a $61 \mathrm{~cm}^{2}$ probe. All of these values are above the maximum total $\alpha$ activity acceptance goal for a $100 \mathrm{~cm}^{2}$ area. The hot spots were around the filter housing, on pipes, on a grate, on the extinguisher nozzle and on the north facing door frame.

The maximum loose activity on large area smears was $200 \mathrm{dpm} / 1 \mathrm{~m}^{2} \alpha$ and $5.9 \mathrm{k} \mathrm{dpm} / 1$ $\mathrm{m}^{2} \beta \gamma$ (see Figure C-12), well below the average removable alpha activity acceptance goal. The highest alpha activity on small area smears was $90 \mathrm{dpm} / 100 \mathrm{~cm}^{2}$; the highest $\beta \gamma$ activity was $540 \mathrm{dpm} / 100 \mathrm{~cm}^{2}$ (see Figure $\mathrm{C}-13$ ). Both are below the maximum removable activity acceptance goals.

\section{K-3 South Wall}

The average gamma readings were between 0.1 and $0.4 \mathrm{mR} / \mathrm{h}$ (see Figure $\mathrm{C}-14$ ). These measurements are below the average contact exposure rate goals. The hot spots were $0.4 \mathrm{mR} / \mathrm{h}$. The hot spots are below the respective maximum contact exposure rate goals.

The average alpha readings in each grid range from $400 \mathrm{dis} / \mathrm{min}$ to $600 \mathrm{dis} / \mathrm{min}$ using a $61 \mathrm{~cm}^{2}$ probe (see Figure $\mathrm{C}-15$ ). All of these values were below the average total alpha activity acceptance goal for $100 \mathrm{~cm}^{2}$. The direct alpha readings for the hot spots were between $1 \mathrm{k}$ $\mathrm{dis} / \mathrm{min}$ and $9 \mathrm{k} \mathrm{dis} / \mathrm{min}$ using a $61 \mathrm{~cm}^{2}$ probe. Many of these values are above the maximum total $\alpha$ activity acceptance goal for $100 \mathrm{~cm}^{2}$. 
The maximum loose activity on large area smears was $480 \mathrm{dpm} / 1 \mathrm{~m}^{2} \alpha$ and $7.1 \mathrm{k} \mathrm{dpm} / 1$ $\mathrm{m}^{2} \beta \gamma$ (see Figure C-16), well below the average removable acceptance goals. The highest alpha activity on small area smears was $260 \mathrm{dpm} / 100 \mathrm{~cm}^{2}$; the highest $\beta \gamma$ activity was $1.2 \mathrm{kdpm} / 100$ $\mathrm{cm}^{2}$ (see Figure C-17). Both are below the maximum removable activity acceptance goals. The smears with the highest loose activities were all in the same grid 2 east, 2 high.

\section{K-3 Floor}

The average gamma readings on the cell floor were $0.1 \mathrm{mR} / \mathrm{h}$ (see Figure $\mathrm{C}-18$ ). These measurements are below the average contact exposure rate acceptance goals. There were no hot spots. The general exposure rate at $13 / 4$ meter above the floor was $0.2 \mathrm{mR} / \mathrm{h}$.

The average alpha readings in each grid were $100 \mathrm{dis} / \mathrm{min}$ using a $61 \mathrm{~cm}^{2}$ probe (see Figure (-19). These are below the acceptance goal. The direct alpha readings for the hot spots were between $1 \mathrm{k} \mathrm{dis} / \mathrm{min}$ and $20 \mathrm{k}$ dis/min using a $61 \mathrm{~cm}^{2}$ probe. Most of these values are above the maximum total $\alpha$ activity acceptance goal for $100 \mathrm{~cm}^{2}$.

The maximum loose activity on large area smears was $440 \mathrm{dpm} / 1 \mathrm{~m}^{2} \alpha$ and $16 \mathrm{kdpm} / 1$ $\mathrm{m}^{2} \beta \gamma$ (see Figure C-20), well below the average removable activity acceptance goals. The highest alpha activity on a small area smear was $90 \mathrm{dpm} / 100 \mathrm{~cm}^{2}$; the highest $\beta \gamma$ activity was $2.5 \mathrm{k} \mathrm{dpm} / 100 \mathrm{~cm}^{2}$ (see Figure C-21). Both are below the maximum removable acceptance goal.

\section{K-3 Overhead}

The only overhead equipment that was surveyed was the one ton capacity bridge crane motor, the trolley frame and rail. The exposure rates were all $0.1 \mathrm{mR} / \mathrm{h}$. The direct alpha readings range from $300 \mathrm{dis} / \mathrm{min}$ to $50 \mathrm{k}$ dis/min using a $61 \mathrm{~cm}^{2}$ probe (see Figure C-22). These values are above the maximum total alpha activity acceptance goal for $100 \mathrm{~cm}^{2}$.

\section{CONCLUSIONS}

\section{Measurements of Residual Radon Gas}

After the verification survey was complete, the amount of airborne activity was measured by two monitors, an RGM-2 and an Alpha- 6 . The Alpha- 6 measured the energy of the alpha 
Verification Survey of

Building 200 Hot Cells

March 1996

particles in the cell and generated the spectrum seen in Figure C-23. Four prominent peaks are seen. A normal alpha spectrum generated from the airborne activity in the POB cells such as $\mathrm{K}-1$ has only 3 peaks (see Figure $\mathrm{C}-24)$. One peak, ${ }^{212} \mathrm{Po}(8.78 \mathrm{MeV})$, is from thoron; one, ${ }^{214} \mathrm{Po}(7.69 \mathrm{MeV})$, is from radon; and one from a combination of ${ }^{218} \mathrm{Po}(6.00 \mathrm{MeV})$ from radon and ${ }^{212} \mathrm{Bi}(6.05 \mathrm{MeV})$ from thoron. Cell $\mathrm{K}-3$ is the only cell which has a distinct peak near 6.7 $\mathrm{MeV}$. The ${ }^{231} \mathrm{~Pa}$ from the source that was repackaged in this cell in 1991 decays through ${ }^{219} \mathrm{Rn}$ to a daughter, ${ }^{211} \mathrm{Bi}$, that emits a $6.62 \mathrm{MeV}$ alpha particle.

The Alpha- 6 normally calculates ${ }^{222} \mathrm{Rn}$ gas concentrations in $\mathrm{pCi} / \mathrm{l}$; and radon and thoron daughter concentrations in milli Working Levels (mWL) from data in the regions of interest (ROI's) defined for the three normal peaks. This extra peak is normally included in the ROI defined for the ${ }^{214} \mathrm{Po}$. To determine if the extra peak was actually from ${ }^{231} \mathrm{~Pa}$, several additional ROI's were defined; one containing 12 channels centered on the extra peak and another containing 15 channels centered on the ${ }^{214} \mathrm{Po}$ peak. An air sample was collected in the cell for 2 hours on a clean filter. The one minute decay data was collected and stored for three hours. Five minute sums that were generated for these two new ROI's are plotted in Figure C-26. The half-lives and $2 \sigma$ uncertainties shown in the figure were calculated from a least squares fit of the data. The $42 \pm 7$ minute value calculated for the ${ }^{214} \mathrm{Po}$ curve is statistically equivalent to a theoretical value between 51 minutes and 34 minutes for the decay of the 26.8 minute ${ }^{214} \mathrm{~Pb}$ and 19.8 minute ${ }^{214} \mathrm{Bi}$ parents for decays from 10 minutes to 50 minutes and 10 minutes to 200 minutes respectively. The $41 \pm 8$ minute value calculated for the ${ }^{211} \mathrm{Bi}$ curve is statistically equivalent to the 36.1 minute half-life of ${ }^{211} \mathrm{~Pb}$, the ${ }^{211} \mathrm{Bi}$ parent.

The ROI $\left(\mathrm{R}_{3}\right)$ centered on the $6.7 \mathrm{MeV}$ peak was also used to calculate a radon daughter concentration $\left(W_{R}\right)$ as a correction of the radon daughter value $\left(W_{B}\right)$ calculated by the Alpha- 6 monitor. An actinon daughter concentration $\left(\mathrm{W}_{\mathrm{A}}\right)$ was also calculated. The contribution of the 6.7 Mev ROI was found to be $12 \%$ of the ${ }^{214} \mathrm{Po}$ ROI $\left(\mathrm{R}_{2}\right)$ for four spectra: Figure 4 from the clean area; Figure A-22 from cell A-1; Figure B-23 from cell K-1; and Figure D-24 from cell M-3. The radon daughter concentration was calculated as: 
Verification Survey of Building 200 Hot Cells March 1996

$$
W_{R}=W_{B}-\frac{7.68\left(1.135 R_{3}-0.135 R_{2}\right)}{V \varepsilon 3.681 \times 10^{6}}
$$

Where $\mathrm{V}$ is the volume of air collected for an hour ( 60 liters); $\epsilon$ is the efficiency of the detector (0.25); and $3.681 \times 10^{6}$ is $28.317 \mathrm{ft}^{3} / 1$ times $1.3 \times 10^{5} \mathrm{MeV} / \mathrm{WL}$. The actinon daughter concentration was calculated by:

$$
W_{A}=\frac{6.62\left(1.135 R_{3}-0.135 R_{2}\right)}{V \varepsilon 3.681 \times 10^{6}}
$$

The concentrations of the $\mathrm{Rn}$ daughter product varies in the same manner as the ${ }^{222} \mathrm{Rn}$ gas concentrations (see Figure C-25). These change much more rapidly than the concentration of thoron (Tn) daughter products in the air from ${ }^{220} \mathrm{Rn}$ which is controlled by the 10.6 hour half-life of ${ }^{212} \mathrm{~Pb}$. The actinon (An) daughter concentration is very flat. The gaps in the data at 2/2/96 and 2/9/96 are due to the week ends when the data were not saved. On 2/5/96 the sampling pump was turned off and the activity on the filter was allowed to decay. The ${ }^{214} \mathrm{Po}$ peak decayed within 4 hours to $2.5 \%$ of its value and the ${ }^{211} \mathrm{Bi}$ peak decayed to $1 \%$ of its value within 5 hours. The residual decayed with a 10.6 hour half-life. Therefore, it was assumed to be the tail of the ${ }^{212}$ Po peak.

An air sampling tube inserted into the cell sampled the air for all radon isotopes, ${ }^{222} \mathrm{Rn}$

${ }^{220} \mathrm{Rn}$, and ${ }^{219} \mathrm{Rn}$ with an RGM-2 monitor. The radon in the cell ranged from $4 \mathrm{pCi} / 1$ to $8 \mathrm{pCi} / 1$ between May 22, 1995 and July 19, 1995 (see Figure C-27). The radon concentrations vary with humidity as measured by the weather station on the main floor of the Shielded Cave Complex. The symbols mark the 6:00 AM measurements for both the humidity and the radon concentrations. Both monitors simultaneously measured the air concentrations from June 23 through June 27,1995 . During this time when the humidity was relatively constant, the radon concentration as measured by the RGM-2 was $\sim 6 \mathrm{pCi} / 1$. The ${ }^{222} \mathrm{Rn}$ concentration as measured by the Alpha- 6 was $\sim 0.5 \mathrm{pCi} / 1$ (see Figure C-28).

\section{Cell Decontamination Summary}

The cell is intended to be left without further decontamination by this project. The identity and quantities of radionuclides that remain in the cell were estimated from the stack emissions. As a conservative estimate, $100 \%$ of the stack emissions were assumed to be ${ }^{220} \mathrm{Rn}$ 
Table 9. Isotopes in Cell K-3 from Stack Emissions

\begin{tabular}{|cc|rll|}
\hline \multicolumn{2}{|c|}{${ }^{2}$ Radionuclide } & $\begin{array}{c}\text { Cat III } \\
\text { mCi }\end{array}$ & $\begin{array}{c}\text { Activity } \\
\text { mCi }\end{array}$ & Ratio \\
\hline \hline${ }^{137} \mathrm{Cs}$ & $\beta$ & 60,000 & 1.7 & $2.8 \times 10^{-5}$ \\
${ }^{90} \mathrm{Sr}$ & $\beta$ & 16,000 & 1.7 & $1.0 \times 10^{-4}$ \\
${ }^{90} \mathrm{Y}$ & $\beta$ & $1,420,000$ & 1.7 & $1.2 \times 10^{-6}$ \\
${ }^{125} \mathrm{Sb}$ & $\beta$ & $1,200,000$ & 0.13 & $1.1 \times 10^{-7}$ \\
${ }^{134} \mathrm{Cs}$ & $\beta$ & 42,000 & 0.063 & $1.5 \times 10^{-6}$ \\
${ }^{154} \mathrm{Eu}$ & $\beta$ & 200,000 & 0.020 & $1.0 \times 10^{-7}$ \\
${ }^{155} \mathrm{Eu}$ & $\beta$ & 940,000 & 0.0041 & $4.4 \times 10^{-9}$ \\
${ }^{232} \mathrm{Th}$ & $\alpha$ & 100 & $<0.00001$ & $9.2 \times 10^{-9}$ \\
${ }^{233} \mathrm{U}$ & $\alpha$ & 4,200 & 0.0028 & $6.6 \times 10^{-7}$ \\
${ }^{232} \mathrm{U}$ & $\alpha$ & 820 & 0.0083 & $1.0 \times 10^{-5}$ \\
${ }^{228} \mathrm{Th}$ & $\alpha$ & 1,000 & 0.0083 & $8.3 \times 10^{-6}$ \\
${ }^{224} \mathrm{Ra}$ & $\alpha$ & 200,000 & 0.0083 & $4.1 \times 10^{-8}$ \\
${ }^{220} \mathrm{Rn}$ & $\alpha$ & 2,000 & 0.0083 & $4.1 \times 10^{-6}$ \\
${ }^{216} \mathrm{Po}$ & $\alpha$ & & 0.0083 & \\
${ }^{212} \mathrm{~Pb}$ & $\beta$ & $3,200,000$ & 0.0083 & $2.6 \times 10^{-9}$ \\
${ }^{212} \mathrm{Bi}$ & $\alpha, \beta$ & & 0.0083 & \\
${ }^{212} \mathrm{Po}$ & $\alpha$ & & 0.0083 & \\
${ }^{208} \mathrm{Tl}$ & $\beta$ & & 0.0083 & \\
${ }^{231} \mathrm{~Pa}$ & $\alpha$ & 210 & 0.00027 & $1.3 \times 10^{-6}$ \\
${ }^{227} \mathrm{Ac}$ & $\beta$ & 42 & 0.00015 & $3.5 \times 10^{-6}$ \\
${ }^{227} \mathrm{Th}$ & $\alpha$ & & 0.00015 & \\
${ }^{223} \mathrm{Ra}$ & $\alpha$ & 62,000 & 0.00015 & $2.4 \times 10^{-9}$ \\
${ }^{219} \mathrm{Rn}$ & $\alpha$ & & 0.00015 & \\
${ }^{215} \mathrm{Po}$ & $\alpha$ & & 0.00015 & \\
${ }^{211} \mathrm{~Pb}$ & $\beta$ & & 0.00015 & \\
${ }^{211} \mathrm{Bi}$ & $\alpha$ & & 0.00015 & \\
${ }^{207} \mathrm{Tl}$ & $\beta$ & & 0.00015 & \\
\hline \hline${ }^{20} \mathrm{Total} \alpha$ & & 0.056 & $2.4 \times 10^{-5}$ \\
$\mathrm{Total} \beta$ & & 5.2 & $1.4 \times 10^{-4}$ \\
& & & 5.3 & $1.6 \times 10^{-4}$ \\
\hline
\end{tabular}


and its daughters. These estimates are presented in Table 9. The radionuclides listed above ${ }^{232} \mathrm{U}$ are estimated from analyses of smear data at the start of the D\&D project. In addition activity from ${ }^{219} \mathrm{Rn}$ is assumed to be $25 \%$ of the activity from ${ }^{220} \mathrm{Rn}$. These activities are compared to the Nuclear Facility Category III quantities. As seen at the bottom of the table, the sum of the ratios is $<0.02 \%$ of the Category III level.

A summary of the hot spots found by the direct surveys are presented in Table 10. Only direct $\alpha$ contamination measurements were above the acceptance goals that are presented in Table 1. The values above the acceptance goals are highlighted and bolded.

Table 10. Direct Survey Hot Spot Summary; Cell K-3

\begin{tabular}{|c|c|c|}
\hline Area & $\mathrm{RO}-20 \mathrm{mR} / \mathrm{h} \gamma$ & $\alpha \mathrm{dis} / \mathrm{min}-61 \mathrm{~cm}^{2}$ \\
\hline West Wall & 0.5 & ᄂ. $15 \%$ to $50 \mathrm{k}$ \\
\hline North Wall & 0.5 & $1 / 261050 k$ \\
\hline East Wall & 0.4 to 0.7 & (. 61 to $90 \mathrm{k}$ \\
\hline South Wall & 0.4 & $4.4110109 \mathrm{k}$ \\
\hline Floor & none & $4.1 \mathrm{k}-10201$ \\
\hline Crane & none & i $1900 \%$ to sok \\
\hline
\end{tabular}

At the present time the general exposure rate at one meter from the walls and floors is $0.2 \mathrm{mR} / \mathrm{h}$. The exposure rates are $0.1 \mathrm{mR} / \mathrm{h}$ at 30 centimeters from the low flow filters and 0.2 $\mathrm{mR} / \mathrm{h}$ at 30 centimeters from the high flow filter. Therefore, workers can enter the cell without concern for external exposure. PPE and respiratory protection have been used for all work including the final survey.

\section{Stack Emissions}

The peak year for emissions since 1984 was 1993 with $18.5 \mathrm{Ci}$ emitted. In 1995 there were $1.7 \mathrm{Ci}$ emitted, $9 \%$ of the 1993 value or $20 \%$ of the 1991 value (see Table 8 and Figure 13). The 1996 values are $\sim 9 \%$ of the 1991 values. 


\section{CELL M-3}

\section{A. INITIAL CELL CONDITION}

\section{Spills and Contamination}

In cell M-3 there were no known spills. There was some loose contamination but little airborne contamination.

\section{Stack Emissions}

Monitoring of the cell M-3 stack emissions was initiated in January 1984 for ${ }^{129} \mathrm{I}$ and ${ }^{85} \mathrm{Kr}$. The monthly emissions were less than $1 \mathrm{Ci}$ during the operation on the fuel rods in 1984 and 1985. Because the ${ }^{85} \mathrm{Kr}$ emissions from this cell were too low to measure at the conclusion of the project, the pumps for the stack monitors were removed on March 3, 1986. Starting in 1991 the ${ }^{220} \mathrm{Rn}$ concentration and flow rate were measured semi-annually. During 1992 it was decided to use M-3 as a staging area for the remote handled waste. A stack monitor was installed in December 1992 to measure the emissions from cell M-3. While the cell was used as a staging area the estimated monthly emissions increased from $<1 \mathrm{Ci}$ in 1991 to $\sim 2 \mathrm{Ci}$ during 1993 and 1994. Since the cell decontamination has been completed, the estimated monthly emissions have been less than $0.1 \mathrm{Ci}$ (see Figure 12 and Table 11).

The quarterly and yearly emissions are presented in Figure 14. No measurements were made from 1986 through 1989. The reduction due to the decontamination effort can be seen by comparing the 1991 values and the values for the last quarter of 1995.

\section{B. DECONTAMINATION}

\section{Waste Removed}

By the summer of 1992 it was determined that remote handled waste had to be moved out of Cell $\mathrm{K}-1$ into a staging area until it could be properly packaged and removed by Waste Management. Cell M-3 was selected as the staging area. Therefore it was remotely cleaned and waste was remotely packaged in the cell starting during September 1992. The tent was constructed and cell entries began during April 1993. Beginning in March 1993 the cell was 


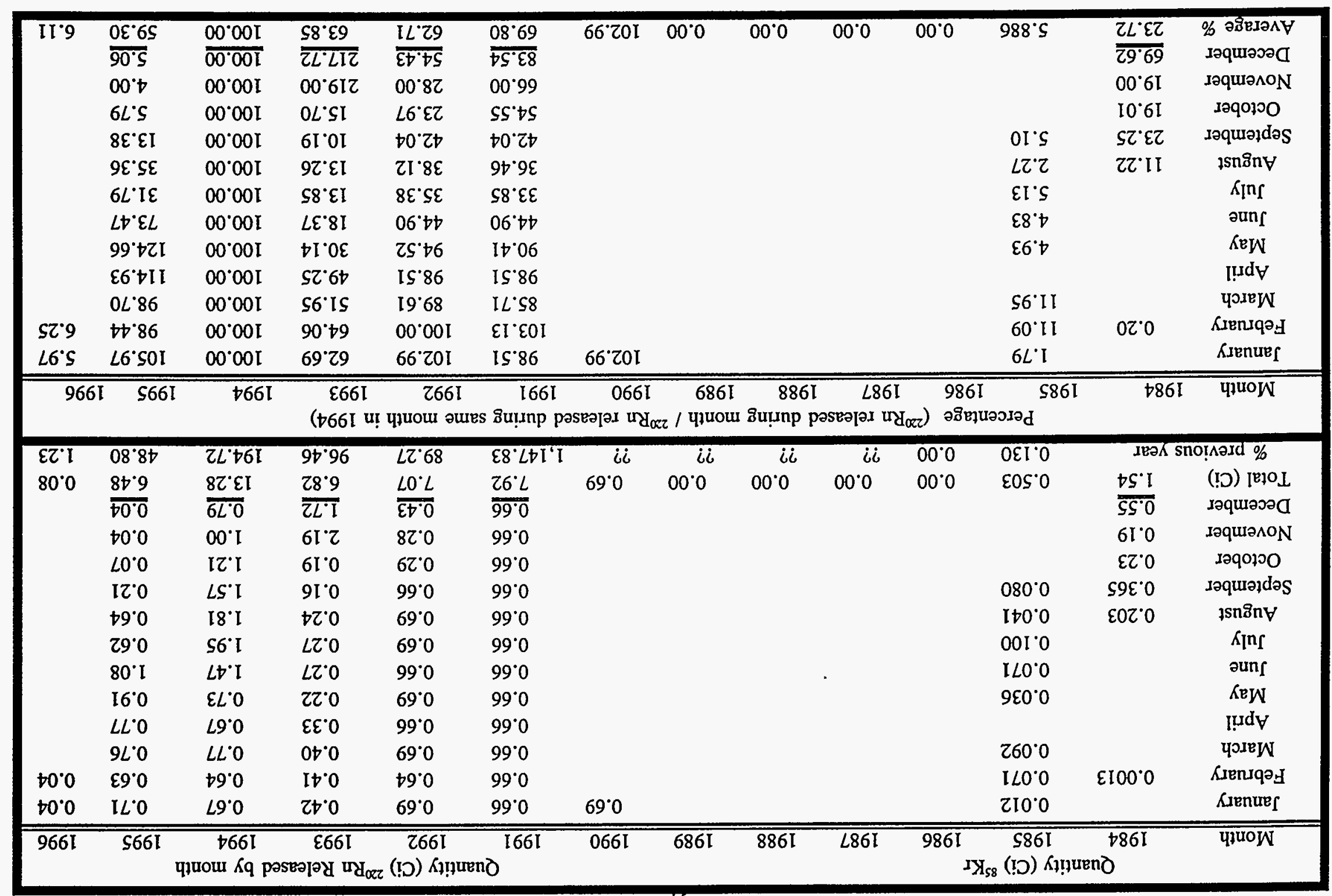

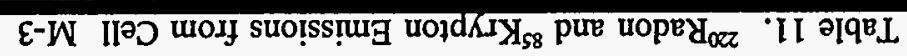

966I บอJEพ 
used to repackage 55-gal drums that had been stored in cell M-4. Remote handled waste cans were transferred from cells K-1 and A-1 during May 1994. The remote handled waste was removed from the cell in June 1995. Once the remote handled waste was removed, the dose rates in the cell were low. The containment boxes were dismantled and the walls and floor were decontaminated through September 1995. The final survey was performed during October 1995.

\section{Accumulated Dose}

The doses were accumulated at 3 separate times; during early 1993, late 1993 and August to October 1995. Initial entries were made in March 1993 and continued through October 1993 to size reduce the shear and package it for removal by waste management. During October to December 1993, waste was moved to this cell and repackaged. During August to October 1994, drums were remotely repackaged and "hot" items were consolidated into fewer drums. During August to October 1995 the cell was completely stripped of experimental equipment. The walls were stripped of the wallpaper. Several applications of strip coat were applied to the walls and floor.

The total whole body (deep) dose that was accumulated during the decontamination of cell M-3 was $\sim 500$ person-mrem (see Figure 7). The total skin (shallow) dose was $\sim 3,000$ person-mrem (see Figure 8 ) and the total extremity (ring) dose was $\sim 1,900$ person-mrem (see Figure 9). The doses were estimated as $100 \%$ of those accumulated from April to October 1993; plus $1 / 2$ of those accumulated during July 1995; plus $10 \%$ of those accumulated from August to October 1995. In addition, the doses for repackaging the drums were $\sim 400$ personrem whole body, $\sim 380$ person-rem skin, and $\sim 470$ person-rem extremity. The drum doses were estimated as $100 \%$ of those accumulated during March 1993 and from October through December 1993.

\section{Decontamination Limit}

The cells were decontaminated to the paint layer. Numerous attempts were made to remove loose contamination that was on the paint. However, no attempt was made to remove the paint or the contamination under the paint. 


\section{FINAL SURVEY RESULTS}

The values that were measured during the survey are compared to the acceptance goals. For each graph containing the direct survey data, the average grid measurements are presented in large numbers in the center of the grid; the elevated readings are presented in smaller numbers at the location of the hot spots. In the legend, the instrument and the corresponding units of the measurements are designated for direct surveys. The smear data is presented as a ratio with the alpha activity printed in the numerator to the beta-gamma activity printed in the denominator. The legend indicates whether the smear covered the large $1 \mathrm{~m}^{2}$ or the small 100 $\mathrm{cm}^{2}$ area near the center of the grid. The layout of cell $\mathrm{M}-3$ is shown in Figure D-1.

\section{M-3 West Wall}

The average gamma readings ranged from $0.5 \mathrm{mR} / \mathrm{h}$ to $1.5 \mathrm{mR} / \mathrm{h}$ (see Figure $\mathrm{D}-2$ ). Only the readings on the lower north grid exceeded the average exposure rate goal. The hot spot readings ranged from $1.0 \mathrm{mR} / \mathrm{h}$ to $3.0 \mathrm{mR} / \mathrm{h}$ on the lights and piping. All hot spots were below the maximum exposure rate goal.

The average alpha readings in each grid including the crane rails and brackets was 100 dis/min using a $61 \mathrm{~cm}^{2}$ probe, below the average alpha activity acceptance goal for $100 \mathrm{~cm}^{2}$. The direct alpha readings of the hot spots ranged from $1 \mathrm{k}$ dis $/ \mathrm{min}$ to $6 \mathrm{k}$ dis $/ \mathrm{min}$ using a $61 \mathrm{~cm}^{2}$ probe (see Figure D-3). Most of the values were above the maximum total $\alpha$ activity acceptance goal for $100 \mathrm{~cm}^{2}$.

The maximum loose activity on large area smears was $220 \mathrm{dpm} / 1 \mathrm{~m}^{2} \alpha$ and $33 \mathrm{k} \mathrm{dpm} / 1$ $\mathrm{m}^{2} \beta \gamma$ (see Figure D-4), well below the Table 1 values. The highest removable activity was in the grid on the lower south side. The highest alpha activity on small area smears was 55 $\mathrm{dpm} / 100 \mathrm{~cm}^{2}$; the highest $\beta \gamma$ activity was $1.4 \mathrm{kdpm} / 100 \mathrm{~cm}^{2}$ (see Figure $\mathrm{D}-5$ ). Both are below the maximum removable activity goals.

\section{M-3 North Walls and Door}

The north wall has many sections including the recess for the low flow HEPA filter and the door. Although some of these sections are actually facing west and others are facing east, 
for this report they will be considered as part of the north wall. The grids behind the HEPA filters to the low flow stack had average exposure rates of $2.0 \mathrm{mR} / \mathrm{h}$ and $3.0 \mathrm{mR} / \mathrm{h}$; for the other grids, the average exposure rate ranged from $0.2 \mathrm{mR} / \mathrm{h}$ to $1.0 \mathrm{mR} / \mathrm{h}$ (see Figure D-6). All measurements were below the appropriate average contact exposure rate goals. The readings on the filters were $10 \mathrm{mR} / \mathrm{h}$, below the maximum contact exposure rate goal for filters. At 30 $\mathrm{cm}$ from the filters, the exposure rate decreased to $2 \mathrm{mR} / \mathrm{h}$.

The average alpha readings in the grids ranged from $100 \mathrm{dis} / \mathrm{min}$ to $200 \mathrm{dis} / \mathrm{min}$ using a $61 \mathrm{~cm}^{2}$ probe (see Figure D-7). The hot spots range from $200 \mathrm{dis} / \mathrm{min}$ to $30 \mathrm{k} \mathrm{dis} / \mathrm{min}$. All of the grid averages are below the acceptance goal. Most of the hot spots on this wall exceed the acceptance goals. The filters had the highest reading.

The maximum loose activity on large area smears was $120 \mathrm{dpm} / 1 \mathrm{~m}^{2} \alpha$ and $19 \mathrm{k} \mathrm{dpm} / 1$ $\mathrm{m}^{2} \beta \gamma$ above the HEPA filters (see Figure D-8), these values are well below the average acceptance goals. The highest alpha activity on small area smears was $290 \mathrm{dpm} / 100 \mathrm{~cm}^{2}$; the highest $\beta \gamma$ activity was $1.4 \mathrm{k} \mathrm{dpm} / 100 \mathrm{~cm}^{2}$ (see Figure $D-9$ ). Both are well below the maximum removable acceptance goals.

\section{M-3 East Wall}

The average gamma readings on the east wall were $0.1 \mathrm{mR} / \mathrm{h}$ including the interior of the transfer port (see Figure D-10). The measurement that is above the average exposure rate on contact was on the light, $0.5 \mathrm{mR} / \mathrm{h}$. This hot spot meets the maximum contact exposure rate acceptance goal.

The average alpha readings in each grid including the crane rail and brackets was 100 dis/min using a $61 \mathrm{~cm}^{2}$ probe (see Figure D-11). All of these values were below the average total alpha activity acceptance goal. The direct alpha readings for the hot spots were between $400 \mathrm{dis} / \mathrm{min}$ and $20 \mathrm{k} \mathrm{dis} / \mathrm{min}$ using a $61 \mathrm{~cm}^{2}$ probe. Only the $20 \mathrm{k}$ dis/min value on the receptacle was above the maximum total $\alpha$ activity acceptance goal for a $100 \mathrm{~cm}^{2}$ area. Other hot spots were on the light and in the transfer port.

The maximum loose activity on large area smears was $86 \mathrm{dpm} / 1 \mathrm{~m}^{2} \alpha$ and $5.7 \mathrm{kdpm} / 1$ $\mathrm{m}^{2} \beta \gamma$ (see Figure D-12), well below the average removable alpha activity acceptance goal. 
The highest alpha activity on small area smears was $71 \mathrm{dpm} / 100 \mathrm{~cm}^{2}$; the highest $\beta \gamma$ activity was $4.5 \mathrm{k} \mathrm{dpm} / 100 \mathrm{~cm}^{2}$ (see Figure D-13). Both are below the maximum removable activity acceptance goals.

\section{M-3 South Wall}

The average gamma readings were between 0.1 and $1.0 \mathrm{mR} / \mathrm{h}$ (see Figure D-14). These measurements are below the average contact exposure rate goals. The hot spot was $3.0 \mathrm{mR} / \mathrm{h}$ on the receptacle. The hot spot was below the respective maximum contact exposure rate goal.

The average alpha readings in each grid was 100 dis/min using a $61 \mathrm{~cm}^{2}$ probe (see Figure D-15). These values were below the average total alpha activity acceptance goal for 100 $\mathrm{cm}^{2}$. The direct alpha readings for the hot spots were between $400 \mathrm{dis} / \mathrm{min}$ and $50 \mathrm{k}$ dis $/ \mathrm{min}$ using a $61 \mathrm{~cm}^{2}$ probe. Four of these values are above the maximum total $\alpha$ activity acceptance goal for $100 \mathrm{~cm}^{2}$.

The maximum loose activity on large area smears was $490 \mathrm{dpm} / 1 \mathrm{~m}^{2} \alpha$ and $32 \mathrm{kdpm} / 1$ $\mathrm{m}^{2} \beta \gamma$, well below the average removable acceptance goals (see Figure D-16). The highest alpha activity on small area smears was $48 \mathrm{dpm} / 100 \mathrm{~cm}^{2}$; the highest $\beta \gamma$ activity was $2.8 \mathrm{k}$ $\mathrm{dpm} / 100 \mathrm{~cm}^{2}$ (see Figure D-17). Both are below the maximum removable activity acceptance goals.

\section{M-3 Floor}

The average gamma readings on the cell floor ranged from $0.1 \mathrm{mR} / \mathrm{h}$ to $2.0 \mathrm{mR} / \mathrm{h}$ (see Figure D-18). Some of these measurements were above the average contact exposure rate acceptance goals. There was one hot spot, $0.5 \mathrm{mR} / \mathrm{h}$ on the grate for the high flow filter. At $30 \mathrm{~cm}$ from the filter the exposure rate decreased to $0.1 \mathrm{mR} / \mathrm{h}$. The general exposure rate at $13 / 4$ meter above the floor was $0.2 \mathrm{mR} / \mathrm{h}$.

The average alpha readings in each grid ranged from $100 \mathrm{dis} / \mathrm{min}$ to $400 \mathrm{dis} / \mathrm{min}$ using a $61 \mathrm{~cm}^{2}$ probe (see Figure D-19). These are below the acceptance goal. The direct alpha readings for the hot spots were between $1 \mathrm{k} \mathrm{dis} / \mathrm{min}$ and $10 \mathrm{k} \mathrm{dis} / \mathrm{min}$ using a $61 \mathrm{~cm}^{2}$ probe. Most of these values are above the maximum total $\alpha$ activity acceptance goal for $100 \mathrm{~cm}^{2}$. 
The maximum loose activity on large area smears was $210 \mathrm{dpm} / 1 \mathrm{~m}^{2} \alpha$ and $19 \mathrm{k} \mathrm{dpm} / 1$ $\mathrm{m}^{2} \beta \gamma$ (see Figure D-20), well below the average removable activity acceptance goals. The highest alpha activity on small area smears was $80 \mathrm{dpm} / 100 \mathrm{~cm}^{2}$; the highest $\beta \gamma$ activity was $8.1 \mathrm{k} \mathrm{dpm} / 100 \mathrm{~cm}^{2}$ (see Figure D-21). Both are below the maximum removable acceptance goal.

For the sake of clarity the survey results for the mule rails, the pits and the plugs are presented separately in Figure D-22. The maximum loose activity in the rails was $220 \mathrm{dis} / \mathrm{min}$ $\alpha$ and $13 \mathrm{k} \mathrm{dis} / \mathrm{min} \beta \gamma$. The pits had direct $\gamma$ readings of $0.5 \mathrm{mR} / \mathrm{h}$. The plugs and the filter grate were smear surveyed and the maximum loose activity was $300 \mathrm{dis} / \mathrm{min} \alpha$ and $32 \mathrm{k} \mathrm{dis} / \mathrm{min}$ $\beta \gamma$. All these survey results were below their respective acceptance goals.

\section{M-3 Overhead}

The only overhead equipment that was surveyed were the one ton capacity bridge crane motor, ballast, the primary and secondary crane bridges and the drive shaft. The exposure rates were all $0.1 \mathrm{mR} / \mathrm{h}$. The direct alpha readings ranged from $50 \mathrm{dis} / \mathrm{min}$ on the primary motor to $4 \mathrm{k}$ dis/min using a $61 \mathrm{~cm}^{2}$ probe on the secondary motor and ballast (see Figure D-23). The maximum large area smear was $3.2 \mathrm{k}$ dis $/ \min \alpha$ and $460 \mathrm{k}$ dis $/ \mathrm{min} \beta \gamma$. The smears on the secondary crane bridge and motor are above the maximum acceptance goals for total and removable $\alpha$ activity and removable $\beta \gamma$ activity.

\section{CONCLUSIONS}

\section{Measurements of Residual Radon Gas}

As a result of the residual contamination from the $\mathrm{POB}$ project, thoron is present in the cell and it is emitted from the stacks. The amount of thoron and naturally occurring radon were measured by an Alpha- 6 monitor. The Alpha- 6 measured the energy of the alpha particle and generated the spectrum seen in Figure D-24. Three prominent peaks are seen; one, ${ }^{212} \mathrm{Po}(8.78$ $\mathrm{MeV})$, from thoron; one, ${ }^{214} \mathrm{Po}(7.69 \mathrm{MeV})$, from radon; and one from a combination of ${ }^{218} \mathrm{Po}$ $(6.00 \mathrm{MeV})$ from radon and ${ }^{212} \mathrm{Bi}(6.05 \mathrm{MeV})$ from thoron.

The Alpha- 6 calculates ${ }^{222} \mathrm{Rn}$ concentrations in $\mathrm{pCi} / 1$ and radon and thoron daughter concentrations in milli Working Levels (mWL). The concentrations of the Rn daughters in the 
March 1996

air from ${ }^{222} \mathrm{Rn}$ varies in the same manner as the ${ }^{222} \mathrm{Rn}$ gas concentrations (see Figure $\mathrm{D}-25$ ). These change much more rapidly than the concentration of the Tn daughters in the air from ${ }^{220} \mathrm{Rn}$ which is controlled by the 10.6 hour half-life of ${ }^{212} \mathrm{~Pb}$.

\section{Cell Decontamination Summary}

The cell is intended to be left without further decontamination by this project. The identity and quantities of radionuclides that remain in the cell were estimated from the stack emissions. These estimates are presented in Table 12. The radionuclides listed above ${ }^{232} \mathrm{U}$ are Table 12. Isotopes in Cell M-3 from Stack Emissions

\begin{tabular}{|c|c|c|c|c|}
\hline \multicolumn{2}{|c|}{ Radionuclide } & \multirow{2}{*}{$\frac{\begin{array}{c}\text { Cat III } \\
\mathrm{mCi}\end{array}}{60,000}$} & \multirow{2}{*}{$\begin{array}{c}\begin{array}{c}\text { Activity } \\
\text { mCi }\end{array} \\
0.77\end{array}$} & \multirow{2}{*}{$\frac{\text { Ratio }}{1.3 \times 10^{-5}}$} \\
\hline${ }^{137} \mathrm{Cs}$ & $\beta$ & & & \\
\hline${ }^{90} \mathrm{Sr}$ & $\beta$ & 16,000 & 0.77 & $4.8 \times 10^{-5}$ \\
\hline${ }^{90} \mathrm{Y}$ & $\beta$ & $1,420,000$ & 0.77 & $4.5 \times 10^{-7}$ \\
\hline${ }^{125} \mathrm{Sb}$ & $\beta$ & $1,200,000$ & 0.062 & $5.1 \times 10^{-8}$ \\
\hline${ }^{134} \mathrm{Cs}$ & $\beta$ & 42,000 & 0.029 & $7.0 \times 10^{-7}$ \\
\hline${ }^{154} \mathrm{Eu}$ & $\beta$ & 200,000 & 0.0096 & $4.8 \times 10^{-8}$ \\
\hline${ }^{155} \mathrm{Eu}$ & $\beta$ & 940,000 & 0.0019 & $2.0 \times 10^{-9}$ \\
\hline${ }^{232} \mathrm{Th}$ & $\alpha$ & 100 & $<0.00001$ & $4.3 \times 10^{-9}$ \\
\hline${ }^{233} \mathrm{U}$ & $\alpha$ & 4,200 & 0.0013 & $3.1 \times 10^{-7}$ \\
\hline${ }^{232} \mathrm{U}$ & $\alpha$ & 820 & 0.0039 & $4.7 \times 10^{-6}$ \\
\hline${ }^{228} \mathrm{Th}$ & $\alpha$ & 1,000 & 0.0039 & $3.9 \times 10^{-6}$ \\
\hline${ }^{224} \mathrm{Ra}$ & $\alpha$ & 200,000 & 0.0039 & $1.9 \times 10^{-8}$ \\
\hline${ }^{220} \mathrm{Rn}$ & $\alpha$ & 2,000 & 0.0039 & $1.9 \times 10^{-6}$ \\
\hline${ }^{216} \mathrm{Po}$ & $\alpha$ & & 0.0039 & \\
\hline${ }^{212} \mathrm{~Pb}$ & $\beta$ & $3,200,000$ & 0.0039 & $1.2 \times 10^{-9}$ \\
\hline${ }^{212} \mathrm{Bi}$ & $\alpha, \beta$ & & 0.0039 & \\
\hline${ }^{212} \mathrm{Po}$ & $\alpha$ & & 0.0039 & \\
\hline${ }^{208} \mathrm{Tl}$ & $\beta$ & & 0.0039 & \\
\hline Tot: & & & 0.03 & $1.1 \times 10^{-5}$ \\
\hline Total & & & 2.4 & $6.2 \times 10^{-5}$ \\
\hline Total c & & & 2.5 & $7.3 \times 10^{-5}$ \\
\hline
\end{tabular}


March 1996

estimated from analyses of smear data at the start of the D\&D project. These activities are compared to the Nuclear Facility Category III quantities. As seen at the bottom of the table, the sum of the ratios is $<0.008 \%$ of the Category III level.

A summary of the hot spots found by the direct surveys are presented in Table 13. Only direct $\alpha$ contamination measurements were above the acceptance goals that are presented in Table 1. The values above the acceptance goals are highlighted and bolded.

Table 13. Direct Survey Hot Spot Summary; Cell M-3

\begin{tabular}{|c|c|c|}
\hline Area & $\mathrm{RO}-20 \mathrm{mR} / \mathrm{h} \gamma$ & $\alpha$ dis $/ \min -61 \mathrm{~cm}^{2}$ \\
\hline West Wall & 1.0 to 3.0 & ४ $1 \mathrm{k}+\mathrm{to} 6 \mathrm{~K}$ \\
\hline North Wall & 10 & 200 to $30 \mathrm{k}$ \\
\hline East Wall & 0.5 & $400 \mathrm{to} 20 \mathrm{k}$ \\
\hline South Wall & 3.0 & $=400$ to $50 \mathrm{~K}$ \\
\hline Floor & 0.5 & औ $1 \mathrm{k}$ lo $10 \mathrm{k} / \%$ \\
\hline Crane & none & $14.4 \mathrm{k} / 4$ \\
\hline
\end{tabular}

At the present time the general exposure rate at $13 / 4$ meter from the walls and floor is 0.2 $\mathrm{mR} / \mathrm{h}$. The exposure rates are $0.1 \mathrm{mR} / \mathrm{h}$ at 30 centimeters from the low flow filter and 2.0 $\mathrm{mR} / \mathrm{h}$ at 30 centimeters from the high flow filter. Workers can enter the cell without concern for external exposure. However, PPE and respiratory protection has been used for all work including the final survey.

\section{Stack Emissions}

The peak year for emissions since 1984 was 1994 (13.3 Ci). The November and December 1993 emissions were $>1$ Ci during the repackaging of the drums from cell M-4. The emissions were also > $1 \mathrm{Ci}$ from June through November 1994 when the remote handled waste was moved from cells K-1 and A-1 and repackaged. During June the discharge rate increased to $50 \mu \mathrm{Ci} / \mathrm{min}$ (see Figure D-26). In June 1995 some of the remaining containers were repackaged prior to the removal of all the remote material from the cell. After this time the 
discharge rate decreased until it stabilized at $\sim 1 \mu \mathrm{Ci} / \mathrm{min}$. After the final decontamination the measured emissions are $\sim 5 \%$ of their peak in 1994 or $\sim 6 \%$ of the 1991 value. These values are so low that they are indistinguishable from the naturally occurring radon levels. 


\section{Cell M-1}

\section{A. INITIAL CELL CONDITION}

\section{Spills and Contamination}

In cell $\mathrm{M}-1$ there were several spills that were not completely cleaned up during the $\mathrm{POB}$ project. This produced extensive loose contamination and airborne contamination. One acid spill on the floor of M-1 had a surface reading of $100 \mathrm{R} / \mathrm{h}$ one foot from the surface at the beginning of the decontamination effort. The air flow from the intake filter passed over this spill before it was channeled into the anteroom and then into the containment boxes. Therefore the anteroom became highly contaminated.

\section{Stack Emissions}

Monitoring of the cell M-1 stack emissions was initiated in December 1983 for ${ }^{129} \mathrm{I},{ }^{85} \mathrm{Kr}$ and ${ }^{220} \mathrm{Rn}$. Hot work in cell M-1 began on December 6, 1983. The stack monitoring has continued through the decontamination of the cells. The ${ }^{129} \mathrm{I}$ and ${ }^{85} \mathrm{Kr}$ emissions from this cell were greater than ${ }^{129} \mathrm{I}$ or ${ }^{85} \mathrm{Kr}$ emissions from either M-3 or K-3. When work on the fuel rods ended, the ${ }^{129} \mathrm{I}$ and ${ }^{85} \mathrm{Kr}$ emissions also ended as seen in Table 14. During 1984 and the first quarter of 1985 there was more krypton emitted than radon.

The ${ }^{220} \mathrm{Rn}$ emissions from cell M-1 peaked at 3,293 $\mathrm{Ci}$ in 1986 after the completion of the work on the fuel rods but during the solidification of the liquid waste and the initial decontamination. The emissions decreased after this decontamination but then increased to a peak 1,898 $\mathrm{Ci}$ in 1992 (see Table 15 and Figure 15) before the start of the final decontamination of this cell began. Figure 16 is an expanded view of the quarterly emissions since 1987 . The monitor was not operational from June 4, 1987 through December 3, 1987. Therefore, the emission estimates during this time appear to be low (see Figure 12). Before the completion of the decontamination, the December 1995 emissions were <3\% of the December 1992 emissions; the 1996 emissions were $\sim 2 \frac{114}{\%}$ of the 1992 emissions as seen in Table 15 . 
Table 14. ${ }^{85} \mathrm{Krypton}$ and ${ }^{129}$ Iodine Emissions from Cell $\mathrm{M}-1$

\begin{tabular}{|ccclc|}
\hline & \multicolumn{2}{c}{ Quantity (Ci) ${ }^{85} \mathrm{Kr}$} & \multicolumn{2}{c|}{ Quantity $(\mu \mathrm{Ci}){ }^{129} \mathrm{I}$} \\
Month & 1984 & 1985 & 1984 & 1985 \\
\hline \hline January & & 3.0 & & 3.2 \\
February & & 25.1 & 0.031 & 5.1 \\
March & & 16.3 & 0.00585 & 9.7 \\
April & & 18.5 & 0.0146 & 0.5 \\
May & & 13.6 & 0.012 & 7.4 \\
June & & 11.4 & 0.033 & 7.0 \\
July & & 17.5 & 0.0098 & 8.1 \\
August & 14.3 & 8.6 & 0.400 & 7.2 \\
September & 13.7 & 9.7 & 0.460 & 7.7 \\
October & 7.8 & 2.9 & 0.345 & 4.0 \\
November & 10.7 & & 2.450 & 0.2 \\
December & $\underline{21.3}$ & & $\frac{4.160}{7.92}$ & $\frac{1.6}{61.7}$ \\
Total (Ci) & 67.8 & 126.6 & & \\
\hline
\end{tabular}

From the start of the project through 1987, the monthly emissions as seen in Figure 12 were related to the effort inside the cell. The monthly emission peak was $441 \mathrm{Ci}$ in December 1986. However from 1988 through 1994, the emissions peaked in the summer months and were low in the winter months. The emissions during the summer months (e.g. 262 curies in August 1991) are more than twice the emissions during the winter months (e.g. 54 curies in January 1991 or $90 \mathrm{Ci}$ in January 1992).

\section{B. DECONTAMINATION}

\section{Waste Removed}

Size reduction and clean up of hot spots was started in the summer of 1992. Because of the high radiation levels, it soon became clear that to make progress, waste had to be removed from the cell. However, the extensive contamination had to be carefully controlled so that contamination of M-5 and M- 6 corridors was minimized. Therefore, cell M-3 was prepared as a staging area and decontamination of the cell M-1 stopped during the summer of 1993 . Remote work resumed in December 1994. All work was performed remotely and waste was packaged in the cell through February 1995. A bag out wall was installed during February 1995 and 
Table 15. ${ }^{220}$ Radon Emissions from Cell $\mathrm{M}-1$

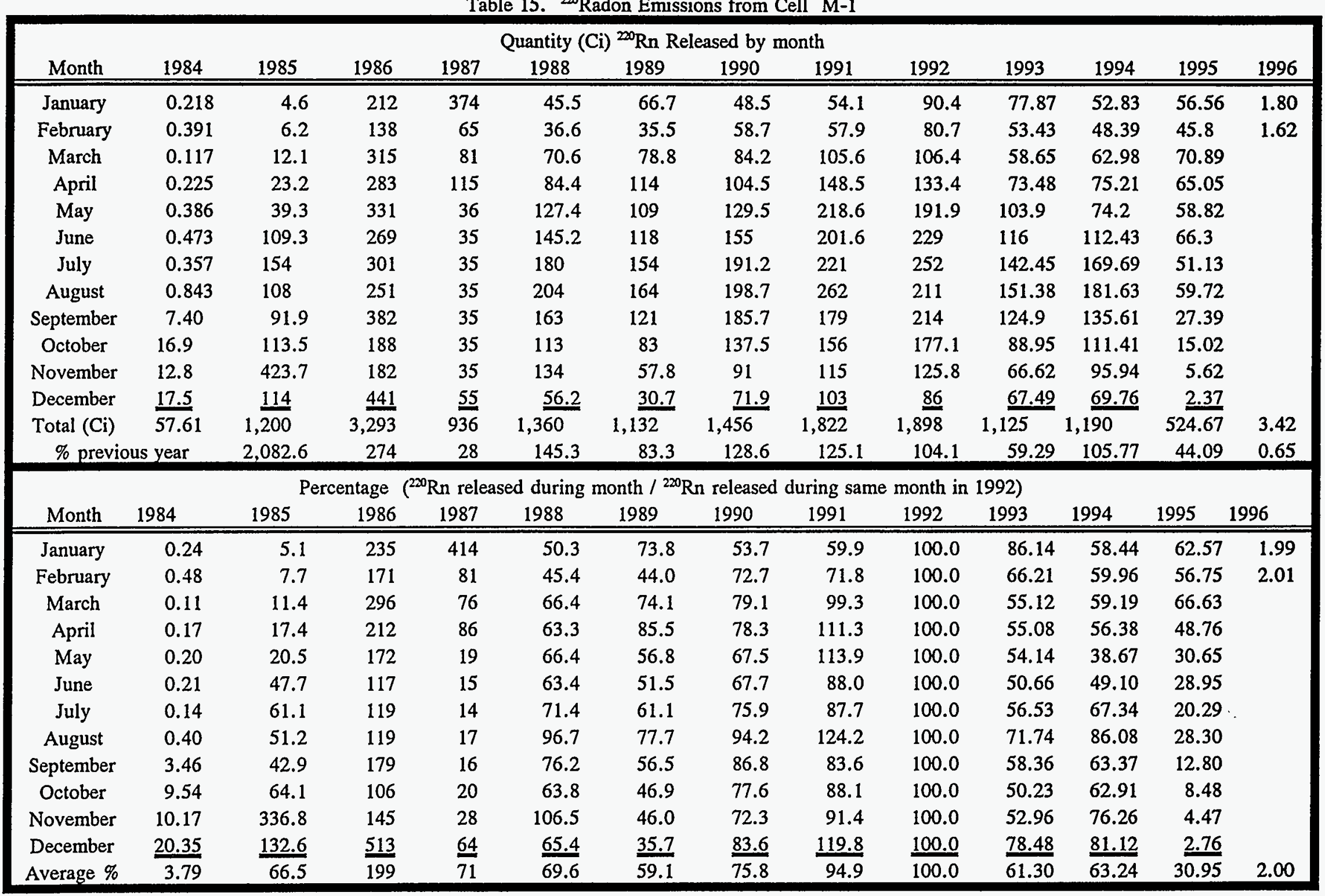


contact handled waste was removed. Remote handled waste was removed after the shielding wall was removed in July 1995. Cell entries also began during July 1995. Removal of floor and wall coverings and decontamination of the interior of the cell started in October 1995. The final survey was initiated during February 1996.

\section{Accumulated Dose}

The doses accumulated from January 1995 through November 1995 are due primarily to the effort to decontaminate this cell. As seen in Figure 7, the doses that were accumulated while waste was removed from the cell through the bag out port from February through July were low. When the wall was removed and cell entries began the doses increased significantly. From August 1995 through January 1996, the cell was stripped of the equipment and the containment boxes that could not be removed through the bag out port in the shielding wall. The wall paper was removed. However stripcoat was not used to decontaminate the walls after the wall paper was removed. The final survey was performed in February 1996.

The total whole body (deep) dose that was accumulated during the decontamination of cell $\mathrm{M}-1$ was $\sim 4,300$ person-mrem. The total skin (shallow) dose was $\sim 18,800$ person-mrem and the total extremity (ring) dose was $\sim 11,300$ person-mrem (see Figures 7 through 9 ). The doses were estimated as 100\% of those accumulated from January 1995 through June 1995; 50\% of those accumulated in July 1995; 90\% of those accumulated from August 1995 through October 1995; and 100\% of those accumulated from November 1995 through February 1996.

\section{Decontamination Limit}

In the cell the wall paper was decontaminated and removed. No attempt was made to remove contamination on the paint because of the lack of time and funding. Scabbling of the floor in the area of the spill is needed to reduce the dose rate inside the cell. A core sample was taken but the floor was not scabbled.

There was contamination on the outside of the north wall and the adjacent floor of the service area. All of the loose contamination on this wall was removed. Scabbling of the wall and floor were terminated when there was no more loose contamination as determined by 
smears. The floor area was patched with concrete. A metal plate was epoxied to the wall area and both were painted with two colors of paint and "Fixed Contamination" was stencilled over the paint.

\section{FINAL SURVEY RESULTS}

The values that were measured during the survey are compared to the acceptance goals. For each graph containing the direct survey data, the average grid measurements are presented in large numbers in the center of the grid; the elevated readings are presented in smaller numbers at the location of the hot spots. In the legend, the instrument and the corresponding units of the measurements are designated for direct surveys. The smear data is presented as a ratio with the alpha activity printed in the numerator to the beta-gamma activity printed in the denominator. The legend indicates that the smear covered the large $1 \mathrm{~m}^{2}$. The layout of cell $\mathrm{M}-1$ is shown in Figure E-1.

Because of the extent of the remaining loose activity in this cell, only large area smears were taken. Both alpha and beta activities on the smears from the north wall were measured with an NE portable survey instrument in the integrate mode. Because of probe contamination problems, the beta activities on the smears from the other surfaces were measured through a plastic bag. In order to estimate the alpha activities on the other smears, the Eberline PAC 4G-3 gas proportional detector was used to measure the alpha activity on one smear from each wall or floor. The alpha/beta ratio of this smear was used to estimate the alpha activities on the other smears from the same wall or floor.

\section{M-1 West Wall}

The average gamma readings ranged from $1.5 \mathrm{mR} / \mathrm{h}$ to $4.0 \mathrm{mR} / \mathrm{h}$ (see Figure $\mathrm{E}-2$ ). All of the readings exceeded the average exposure rate goal. The hot spot readings ranged from 4.0 $\mathrm{mR} / \mathrm{h}$ to $5.0 \mathrm{mR} / \mathrm{h}$ on the lights, pipes and in the transfer port. Most hot spots were less than or equal to the maximum exposure rate goal.

The average alpha readings in each grid including the crane rails and brackets ranged from $100 \mathrm{dis} / \mathrm{min}$ to $500 \mathrm{dis} / \mathrm{min}$ using a $61 \mathrm{~cm}^{2}$ probe, below the average alpha activity 
March 1996

acceptance goal for $100 \mathrm{~cm}^{2}$. The direct alpha readings of the hot spots ranged from $1 \mathrm{k} \mathrm{dis} / \mathrm{min}$ to $500 \mathrm{k} \mathrm{dis} / \mathrm{min}$ using a $61 \mathrm{~cm}^{2}$ probe (see Figure E-3). Most of the values were above the maximum total $\alpha$ activity acceptance goal for $100 \mathrm{~cm}^{2}$. There are numerous hot spots. The highest activities were on the manipulator hands.

The alpha/beta ratio from the grid 4 north, 1 high was used to estimate the removable alpha activities in the other grids. The maximum loose activity on large area smears was estimated as $900 \mathrm{dpm} / 1 \mathrm{~m}^{2} \alpha$ and measured as $81 \mathrm{k} \mathrm{dpm} / 1 \mathrm{~m}^{2} \beta \gamma$ (see Figure E-4), below the Table 1 values. The highest removable activity was in the grid in the second row on the south side.

\section{M-1 North Wall}

The average exposure rates ranged from $1.5 \mathrm{mR} / \mathrm{h}$ to $5.0 \mathrm{mR} / \mathrm{h}$ (see Figure E-5). All measurements were above the average contact exposure rate goals. The hot spots readings ranged from $1 \mathrm{mR} / \mathrm{h}$ to $45 \mathrm{mR} / \mathrm{h}$ on fixtures, around the window and on the wall. Many are above the maximum contact exposure rate goal.

The average alpha readings in the grids ranged from $600 \mathrm{dis} / \mathrm{min}$ to $8 \mathrm{k} \mathrm{dis} / \mathrm{min}$ using a $61 \mathrm{~cm}^{2}$ probe (see Figure E-6). The hot spots range from $6 \mathrm{k}$ dis $/ \mathrm{min}$ to $>1 \mathrm{M}$ dis $/ \mathrm{min}$. Many of the grid averages are above the acceptance goal. All of the hot spots on this wall exceed the acceptance goals. The activities $\geq 1 \mathrm{M} \mathrm{dis/min} \mathrm{were} \mathrm{on} \mathrm{the} \mathrm{viewing} \mathrm{window} \mathrm{and} \mathrm{the} \mathrm{concrete}$ surfaces to the east of the window.

The maximum loose activity on large area smears was $6 \mathrm{k} \mathrm{dpm} / 1 \mathrm{~m}^{2} \alpha$ and $4.3 \mathrm{M} \mathrm{dpm} / 1$ $\mathrm{m}^{2} \beta \gamma$ in the center grid along the floor (see Figure E-7), these values are above the average acceptance goals. All of the alpha activities were measured with an NE detector.

\section{M-1 East Wall}

The average gamma readings on the east wall ranged from $2.0 \mathrm{mR} / \mathrm{h}$ to $7.0 \mathrm{mR} / \mathrm{h}$ (see Figure E-8). All are above the average contact exposure rate acceptance goal. The hot spots ranged from $4.0 \mathrm{mR} / \mathrm{h}$ to $10 \mathrm{mR} / \mathrm{h}$ on light fixtures and at the bottom of the viewing window. Many of the hot spots exceed the maximum contact exposure rate acceptance goal. 
The average alpha readings in each grid ranged from $500 \mathrm{dis} / \mathrm{min}$ to $10 \mathrm{k} \mathrm{dis} / \mathrm{min}$ using a $61 \mathrm{~cm}^{2}$ probe (see Figure E-9). The direct alpha readings for the hot spots were between $4 \mathrm{k}$ dis/min and $1 \mathrm{M}$ dis/min using a $61 \mathrm{~cm}^{2}$ probe. All of the values were above the maximum total $\alpha$ activity acceptance goal for a $100 \mathrm{~cm}^{2}$ area. The highest activity was on the viewing window.

The alpha/beta ratio from the grid 3 north, 1 high was used to estimate the removable alpha activities in the other grids. The maximum loose activity on large area smears was $20 \mathrm{k}$ $\mathrm{dpm} / 1 \mathrm{~m}^{2} \alpha$ and $680 \mathrm{k} \mathrm{dpm} / 1 \mathrm{~m}^{2} \beta \gamma$ (see Figure E-10). This alpha activity equals the average removable activity acceptance goal, and the beta activity is below the average removable activity acceptance goal.

\section{M-1 South Walls and Door}

The south wall has many sections including recesses for the low flow prefilters and the door. Although some of the sections are actually facing west and others are facing east, for this report they will be considered as part of the south wall. The average gamma readings were between 1.5 and $5.0 \mathrm{mR} / \mathrm{h}$ (see Figure E-11). These measurements are above the average contact exposure rate goals. The only hot spots were on the filters at $20 \mathrm{mR} / \mathrm{h}$. The filters were below their respective maximum contact exposure rate goal. At $30 \mathrm{~cm}$ from the filter, the dose rate was $5.0 \mathrm{mR} / \mathrm{h}$.

The average alpha readings in each grid ranged from $200 \mathrm{dis} / \mathrm{min}$ to $4 \mathrm{k}$ dis $/ \mathrm{min}$ using a $61 \mathrm{~cm}^{2}$ probe (see Figure E-12). These values were at or below the average total alpha activity acceptance goal for $100 \mathrm{~cm}^{2}$. The direct alpha readings for the hot spots were between $4 \mathrm{k}$ $\mathrm{dis} / \mathrm{min}$ and $700 \mathrm{k} \mathrm{dis} / \mathrm{min}$ using a $61 \mathrm{~cm}^{2}$ probe. All of these values are above the maximum total $\alpha$ activity acceptance goal for $100 \mathrm{~cm}^{2}$. The highest activities were on the filter housing.

The alpha/beta ratio from the grid 4 east, 1 high was used to estimate the removable alpha activities in the other grids. The maximum loose activity on large area smears was estimated as $1 \mathrm{kdpm} / 1 \mathrm{~m}^{2} \alpha$ and measured as $71 \mathrm{k} \mathrm{dpm} / 1 \mathrm{~m}^{2} \beta \gamma$, below the average removable acceptance goals (see Figure E-13). 


\section{M-1 Floor}

A lead blanket was used on the floor to shield the workers from the high exposure rates produced by the floor contamination. A $2 \frac{1}{2}$ inch diameter core sample was cut six inches deep. The sample was removed from the floor area with a high direct reading, $800 \mathrm{mR} / \mathrm{h}$ on contact. The sample was cut into four disks. The top three were each an inch thick and the deepest one was three inches thick. The dose rates from the disks were measured at contact and at $30 \mathrm{~cm}$ with an RO-20 ion chamber. The disks were sent to the Analytical Chemistry Laboratory (ACL) for gamma spectrometric analysis and alpha spectrometric analysis of chips from the top and bottom disks. Since there was still $62 \mathrm{pCi}{ }^{137} \mathrm{Cs}$ in the bottom disk, chips were removed to determine the level of Uranium contamination at the six inch depth. The analytical results are presented in Table 16. Since the main purpose of the analysis was to assist in determining the depth of the contamination, this was determined to be adequate. Environmental ${ }^{137} \mathrm{Cs}$ activity is the result of fall-out from atomic bomb blasts. Therefore, the soil concentrations should be a good indicator of the maximum expected uncontaminated concrete activities. The activities of soil around Argonne National Laboratory during 1994 as recorded in Golchert 1995 are also presented in Table 16. The bottom disk has 126 times the environmental ${ }^{137} \mathrm{Cs}$ activity. Environmental ${ }^{134} \mathrm{Cs}$ activities are below the detection limit. The chips from the bottom disk indicated that acid solution carried the contamination at least six inches into the concrete.

The average gamma readings on contact with the cell floor ranged from $1.5 \mathrm{mR} / \mathrm{h}$ to 75 $\mathrm{mR} / \mathrm{h}$ (see Figure E-14). All of these measurements were above the average contact exposure rate acceptance goals. The hot spots ranged from $3.5 \mathrm{mR} / \mathrm{h}$ to $1 \mathrm{R} / \mathrm{h}$ in the area of the spill under the lead blanket.

To keep the dose to the personnel performing the survey ALARA, the area under the lead blanket was not scanned for total alpha activity. It was spot checked and found to be greater than the maximum meter reading, $>1 \mathrm{M}$ dis/min using a $61 \mathrm{~cm}^{2}$ probe. The average alpha readings in the other grids ranged from $4 \mathrm{k}$ dis $/ \mathrm{min}$ to $200 \mathrm{k}$ dis $/ \mathrm{min}$ using a $61 \mathrm{~cm}^{2}$ probe (see Figure E-15). These are above the acceptance goal. The direct alpha readings for the hot spots were between $40 \mathrm{k}$ dis $/ \mathrm{min}$ and $>1 \mathrm{M} \mathrm{dis} / \mathrm{min}$ using a $61 \mathrm{~cm}^{2}$ probe. All of these values are 
March 1996

Table 16. M-1 Core Sample Results

\begin{tabular}{|c|c|c||c|c||c|c|c||}
\hline \multirow{2}{*}{ Section } & \multicolumn{2}{|c|}{$\gamma$ Spec (pCi/g) } & \multicolumn{2}{c||}{ RO20 (mR/h) } & \multicolumn{3}{c||}{$\alpha$ Spec Chip (pCi/g) } \\
\cline { 2 - 8 } & ${ }^{134} \mathrm{Cs}$ & ${ }^{137} \mathrm{Cs}$ & Contact & $030 \mathrm{~cm}$ & ${ }^{232} \mathrm{U}$ & ${ }^{233 / 234} \mathrm{U}$ & ${ }^{238} \mathrm{U}$ \\
\hline \hline Top Chip & & $72,000 \mathrm{k}$ & & & 33,600 & 11,200 & \\
\hline Top & $143 \mathrm{k} \pm 14 \mathrm{k}$ & $9,260 \mathrm{k} \pm 930 \mathrm{k}$ & 100 & 4 & & & \\
\hline Second & $78 \pm 8$ & $4,870 \pm 490$ & 0.5 & 0.1 & & & \\
\hline Third & $1.9 \pm 0.2$ & $124 \pm 12$ & 0.3 & $<0.1$ & & & \\
\hline Bottom & $1.1 \pm 0.1$ & $62 \pm 6$ & 0.5 & 0.1 & & & \\
\hline Bottom Chips & & & & & $1.91 \pm 0.06$ & $1.35 \pm 0.05$ & $0.31 \pm 0.03$ \\
\hline \hline Soil & & $0.49 \pm 0.4$ & & & & $1.1 \pm 0.4$ \\
\hline
\end{tabular}


above the maximum total $\alpha$ activity acceptance goal for $100 \mathrm{~cm}^{2}$. There is extensive contamination with many areas that pegged the meter at $>1 \mathrm{M}$ dis/min.

The alpha/beta ratio from the grid 1 north, 3 east was used to estimate the removable alpha activities in the other grids. The maximum loose activity on large area smears was estimated as $57 \mathrm{k} \mathrm{dpm} / 1 \mathrm{~m}^{2} \alpha$ and $1.5 \mathrm{M} \mathrm{dpm} / 1 \mathrm{~m}^{2} \beta \gamma$ (see Figure E-16). Both are above the average removable activity acceptance goals. This grid contains part of the area covered with the lead blanket and other hot spots with direct alpha activities $>1 \mathrm{M}$ dis $/ \mathrm{min}$.

For the sake of clarity the survey results for the mule rails, the pits and the plugs are presented separately in Figure E-17. The maximum gamma reading was $1 \mathrm{R} / \mathrm{h}$ in the rails. Through the lead blanket, the dose rate was $150 \mathrm{mR} / \mathrm{h}$ at the blanket surface and $50 \mathrm{mR} / \mathrm{h}$ at 30 $\mathrm{cm}$. At $13 / 4$ meters from the floor the dost rate was $10 \mathrm{mR} / \mathrm{h}$ over the blanket. For other areas of the cell, the dose rate at $13 / 4$ meters was $5.0 \mathrm{mR} / \mathrm{h}$. The prefilter housing for the high flow stack was $50 \mathrm{mR} / \mathrm{h}$ on contact and $10 \mathrm{mR} / \mathrm{h}$ at $30 \mathrm{~cm}$.

The maximum direct alpha reading was $200 \mathrm{k} \mathrm{dis} / \mathrm{min}$ for a $61 \mathrm{~cm}^{2}$ probe in the rails. One of the lifting lugs had removable $\beta \gamma$ activity up to $4 \mathrm{M}$ dis/min. The direct survey results were above their respective acceptance goals.

\section{M-1 Overhead}

The only overhead equipment that was surveyed were the one ton capacity bridge crane motor, hook, bucket, crane bridges and the drive shaft. The exposure rates ranged from 5.0 $\mathrm{mR} / \mathrm{h}$ on the trolley to $50 \mathrm{mR} / \mathrm{h}$ on the bucket. The direct alpha readings ranged from $10 \mathrm{k}$ $\mathrm{dis} / \mathrm{min}$ on the crane top to $600 \mathrm{k}$ dis/min on a hook using a $61 \mathrm{~cm}^{2}$ (see Figure E-18).

\section{M-1 North Wall Outside the Cell}

The gamma reading on the outside of the north wall was $12 \mathrm{mR} / \mathrm{h}$ on contact before it was covered with a metal plate and $0.1 \mathrm{mR} / \mathrm{h}$ through the plate (see Figure E-19).

The direct alpha readings for the hot spots were between $100 \mathrm{dis} / \mathrm{min}$ and $3 \mathrm{k} \mathrm{dis} / \mathrm{min}$ using a $100 \mathrm{~cm}^{2}$ probe. None of the values were above the maximum total $\alpha$ activity acceptance 
goal for a $100 \mathrm{~cm}^{2}$ area. The direct $\beta \gamma$ readings ranged from $6.5 \mathrm{k} \mathrm{dis} / \mathrm{min}$ to $820 \mathrm{k} \mathrm{dis} / \mathrm{min}$ using a $100 \mathrm{~cm}^{2}$ probe.

\section{CONCLUSIONS}

\section{Measurements of Residual Radon Gas}

As a result of the residual contamination from the $\mathrm{POB}$ project, thoron is present in the cell and it is emitted from the stacks. The amount of thoron and naturally occurring radon were measured by an Alpha- 6 . The Alpha- 6 measured the energy of the alpha particle and generated the spectrum seen in Figure E-20. Two prominent peaks are seen; one, ${ }^{212} \mathrm{Po}(8.78 \mathrm{MeV})$, from thoron; and the other from ${ }^{212} \mathrm{Bi}(6.05 \mathrm{MeV})$ also from thoron. The ${ }^{214} \mathrm{Po}(7.69 \mathrm{MeV})$, from radon, present in the spectra from the other cells is missing. An M-1 concentration of ${ }^{222} \mathrm{Rn}$ similar to concentrations found in the other cells would be indistinguishable from the low energy tail of the ${ }^{212}$ Po peak.

The Alpha- 6 calculates ${ }^{222} \mathrm{Rn}$ concentrations in $\mathrm{pCi} / \mathrm{l}$ and radon and thoron daughter concentrations in milli Working Levels ( $\mathrm{mWL}$ ). The calculated concentration of decay products in the air from ${ }^{222} \mathrm{Rn}$ is much lower than the concentration of decay products from ${ }^{220} \mathrm{Rn}$ (see Figure E-21). The calculated ${ }^{222} \mathrm{Rn}$ gas concentration is approximately equal to zero. The fact that it is negative at times is caused by subtracting a fraction of the large $8.78 \mathrm{MeV}$ peak from the smaller $6 \mathrm{MeV}$ peak to obtain the ${ }^{222} \mathrm{Rn}$ concentration which is less than $5 \%$ of the ${ }^{220} \mathrm{Rn}$ concentrations.

\section{Cell Decontamination Summary}

The cell is intended to be left without further decontamination by this project. The identity and quantities of radionuclides that remain in the cell were estimated from the stack emissions. The estimates as based on the emissions after the HEPA filters in the fan loft were changed on February 16, 1996 are presented in Table 17. The radionuclides listed above ${ }^{232} \mathrm{U}$ are estimated from analyses of smear data at the start of the D\&D project and the core sample ratios. These activities are compared to the Nuclear Facility Category III quantities. As seen at the bottom of the table, the sum of the ratios is $<2 \%$ of the Category III level. 
Table 17. Isotopes in Cell M-1 from Stack Emissions

\begin{tabular}{|cc|rcc|}
\hline \multicolumn{2}{|c|}{ Radionuclide } & $\begin{array}{c}\text { Cat III } \\
\text { mCi }\end{array}$ & $\begin{array}{c}\text { Activity } \\
\text { mCi }\end{array}$ & Ratio \\
\hline \hline${ }^{137} \mathrm{Cs}$ & $\beta$ & 60,000 & 210 & $3.5 \times 10^{-3}$ \\
${ }^{90} \mathrm{Sr}$ & $\beta$ & 16,000 & 210 & $1.3 \times 10^{-2}$ \\
${ }^{90} \mathrm{Y}$ & $\beta$ & $1,420,000$ & 210 & $1.5 \times 10^{-4}$ \\
${ }^{125} \mathrm{Sb}$ & $\beta$ & $1,200,000$ & 17 & $1.4 \times 10^{-5}$ \\
${ }^{134} \mathrm{Cs}$ & $\beta$ & 42,000 & 8.0 & $1.9 \times 10^{-4}$ \\
${ }^{154} \mathrm{Eu}$ & $\beta$ & 200,000 & 2.6 & $1.3 \times 10^{-5}$ \\
${ }^{155} \mathrm{Eu}$ & $\beta$ & 940,000 & 0.52 & $5.6 \times 10^{-7}$ \\
${ }^{232} \mathrm{Th}$ & $\alpha$ & 100 & 0.00012 & $1.2 \times 10^{-6}$ \\
${ }^{233} \mathrm{U}$ & $\alpha$ & 4,200 & 0.086 & $2.1 \times 10^{-5}$ \\
${ }^{232} \mathrm{U}$ & $\alpha$ & 820 & 0.26 & $3.2 \times 10^{-4}$ \\
${ }^{228} \mathrm{Th}$ & $\alpha$ & 1,000 & 0.26 & $2.6 \times 10^{-4}$ \\
${ }^{224} \mathrm{Ra}$ & $\alpha$ & 200,000 & 0.26 & $1.3 \times 10^{-6}$ \\
${ }^{220} \mathrm{Rn}$ & $\alpha$ & 2,000 & 0.26 & $1.3 \times 10^{-4}$ \\
${ }^{216} \mathrm{Po}$ & $\alpha$ & & 0.26 & \\
${ }^{212} \mathrm{~Pb}$ & $\beta$ & $3,200,000$ & 0.26 & $8.1 \times 10^{-8}$ \\
${ }^{212} \mathrm{Bi}$ & $\alpha, \beta$ & & 0.26 & \\
${ }^{212} \mathrm{Po}$ & $\alpha$ & & 0.26 & \\
${ }^{208} \mathrm{Tl}$ & $\beta$ & & 0.26 & \\
\hline \hline \multicolumn{2}{|c|}{ Total $\alpha$} & & 1.7 & $7.3 \times 10^{-4}$ \\
Total $\beta$ & & 660 & 0.017 \\
$\mathrm{Total} \alpha+\beta$ & & 662 & 0.018 \\
\hline
\end{tabular}

A summary of the hot spots found by the direct surveys are presented in Table 18. The values above the acceptance goals are highlighted and bolded. Many of the direct measurements and some the large areas smears were above the acceptance goals that are presented in Table 1. 
Table 18. Direct Survey Hot Spot Summary; Cell M-1

\begin{tabular}{|c|c|c|}
\hline Area & $\mathrm{RO}-20 \mathrm{mR} / \mathrm{h} \gamma$ & $\alpha \operatorname{dis} / \min -61 \mathrm{~cm}^{2}$ \\
\hline West Wall & $1=40605 \%$ & /k $160500 \mathrm{k}$ \\
\hline North Wall & $19100045 \%$ & $2=6 \mathrm{ko}>1 \mathrm{Ml}$ \\
\hline East Wall & $40 \operatorname{tol} 10$ & 今 $4 \mathrm{k}$ to $1 \mathrm{M}$ \\
\hline South Wall & 20 & $4=4 \mathrm{ko} 700 \mathrm{~s}$ \\
\hline Floor & 3,5 to 1,000 & $480 \mathrm{k} / 0>>\mathrm{nm}$ \\
\hline Crane & 4.4 o so & 1016 to $600 \mathrm{k}$ \\
\hline Outside $\mathrm{N}$ Wall & 0.1 & 100 to $3 \mathrm{k}$ \\
\hline
\end{tabular}

At the present time the general exposure rate at $13 \frac{34}{4}$ meters from the walls and floors is $5.0 \mathrm{mR} / \mathrm{h}$. In the center of the cell, over the blanket, the exposure rate is $10 \mathrm{mR} / \mathrm{h}$. The exposure rate at $30 \mathrm{~cm}$ from the high flow filter on the floor was $10 \mathrm{mR} / \mathrm{h}$. The exposure rate at $30 \mathrm{~cm}$ from the low flow filters on the south wall was $5.0 \mathrm{mR} / \mathrm{h}$. Workers who enter the cell need to be concerned about external exposure. Also, some level of PPE and respiratory protection would be required for work in the cell.

\section{Stack Emissions}

Before the decontamination project began, the discharge rate of the air from the M-1 stacks ranged from $900 \mu \mathrm{Ci} / \mathrm{min}$ to $7,500 \mu \mathrm{Ci} / \mathrm{min}$ as seen in Figure E-22, that presents the values from February 1992 through March 1993. During the final stages of the decontamination project, the discharge of the air from the M-1 stacks ranged from $30 \mu \mathrm{Ci} / \mathrm{min}$ to $80 \mu \mathrm{Ci} / \mathrm{min}$ for December 1995 and January 1996. After the HEPA filters in the fan loft were changed in February 1996, the discharge rate decreased to a minimum of $\sim 25 \mu \mathrm{Ci} / \mathrm{min}$. The large fluctuations in the discharge rate are due the large variations in the measured flow rate.

The peak year for emissions since 1986 was 1992 (1,898 Ci). In 1995 there were 525 $\mathrm{Ci}$ emitted 28\% of the 1992 value (see Table 15 and Figure 16). In 1995 the emissions decreased in April with respect to the previous month. In Figure 12 it can be seen that this is 
very unusual. The pre-filters in the cell were changed at the end of February 1995 and the final removal of equipment began in August 1995. The final decontamination was completed in January 1996. The January and February 1996 emissions are $~ 2 \%$ of the 1992 emissions and $\sim 3 \%$ of the 1991 emissions.

The January and February 1996 emissions from the four POB cells; M-1, K-1, M-3 and $\mathrm{K}-3$ are $\sim 2 \frac{1}{4} \%$ of the 1991 emissions. 


\section{REFERENCES}

Graczyk, D. F., et al, 1987 Final Report for the Light Water Breeder Reactor Proof-of-Breeding Analytical Support Project, Argonne National Laboratory, Report ANL-87--2 (May)

Heinrich, R. R., et al, 1985 Uranium and Plutonium Determination for Evaluation of High Burnup Fuel Performance, Argonne National Laboratory, Report (June)

January 1992, Environmental Assessment for Decontamination of Building 200, M-Wing Hot Cells at Argonne National Laboratory

April 1993, Building 200 hot Cells Decontamination Project; Project Management Document "Building 200 Hot Cells Decontamination Project Quality Assurance Plan", Report No. 78016$1 \mathrm{~A}-02$

January 1995, Building 200 Hot Cells Decontamination Project; Standard Operating Procedure "Final Radiological Cell Survey", SOP 4.9

Golchert, N. W. and R. G. Kolzow, 1995 Argonne National Laboratory - East Site Environmental Report for Calendar Year 1994, Argonne National Laboratory, Report ANL-95/8 (May). 


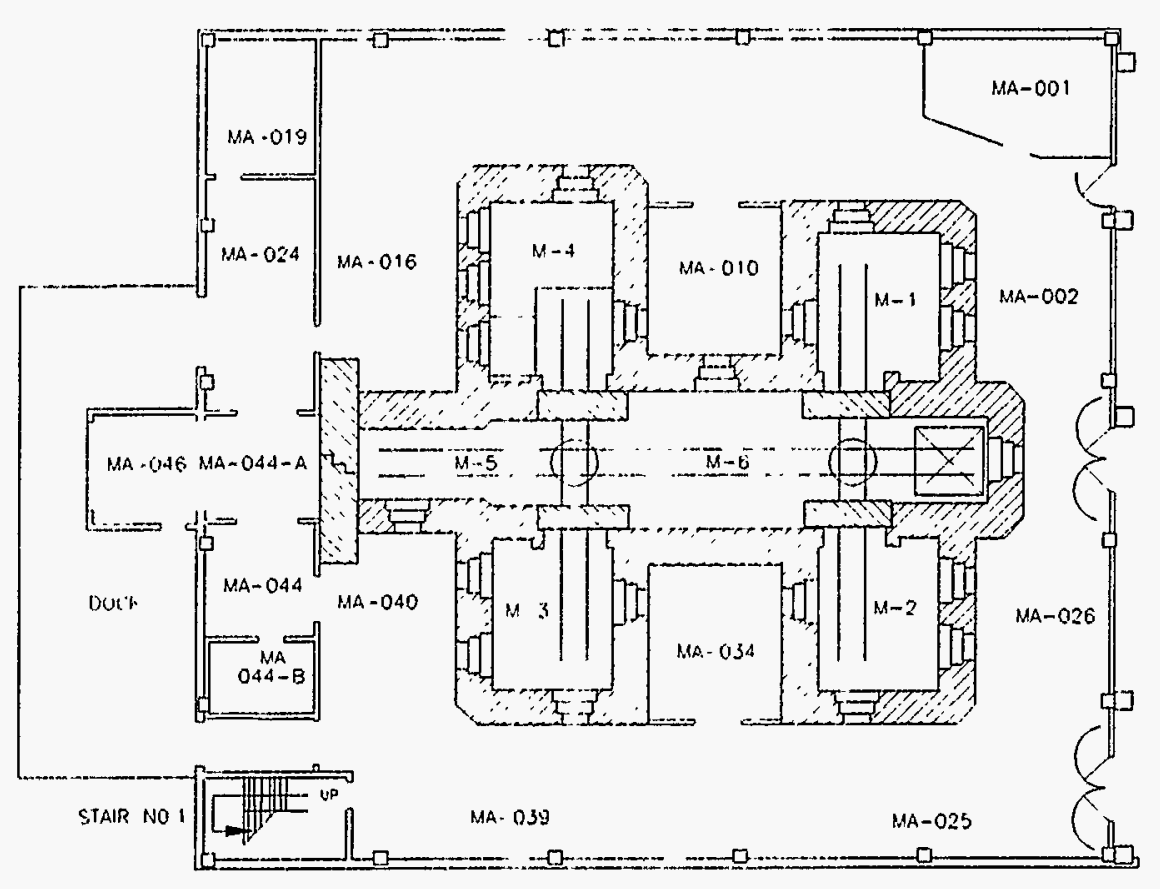

LOWER FLOOR

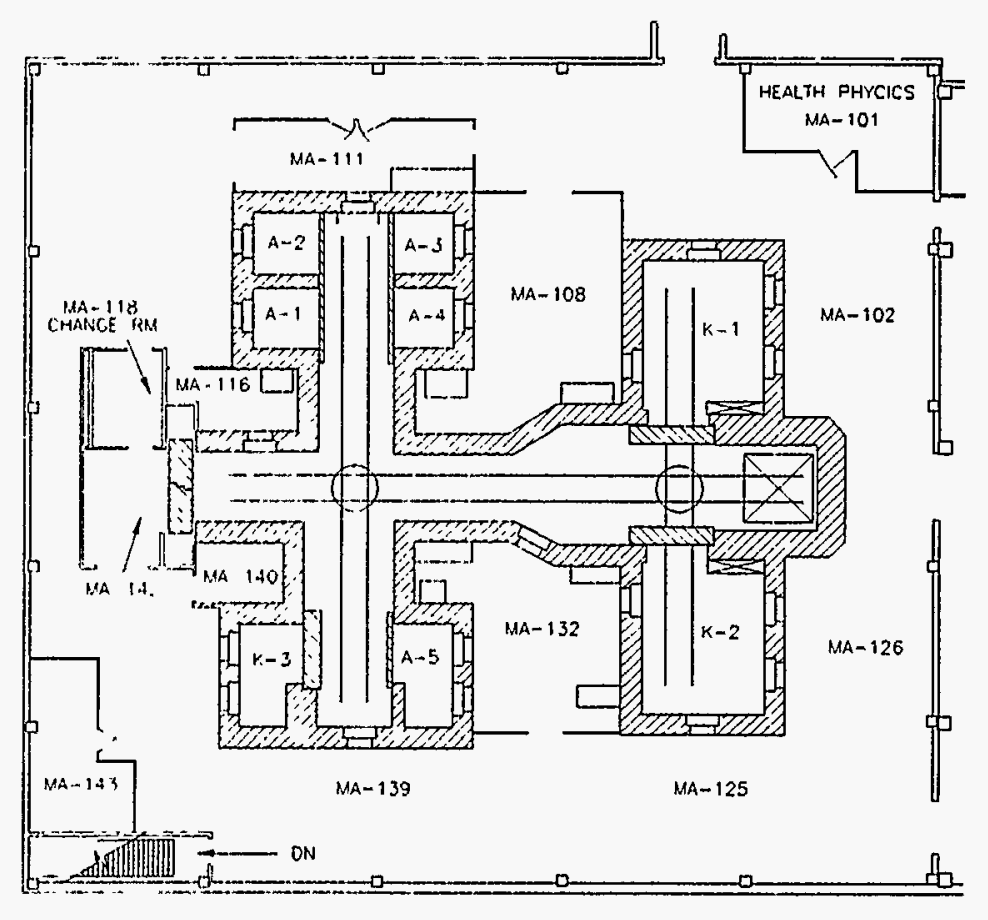

MAIN FLOOR

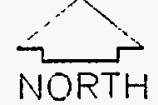




\section{Figure 2. Fissionable ${ }^{233} \mathrm{U}$ from ${ }^{222} \mathrm{Th} ;$ ${ }^{238} \mathrm{U} \&{ }^{239} \mathrm{Pu} /{ }^{235} \mathrm{U}$ Decay}

Pathway \#1 Pathway \#2

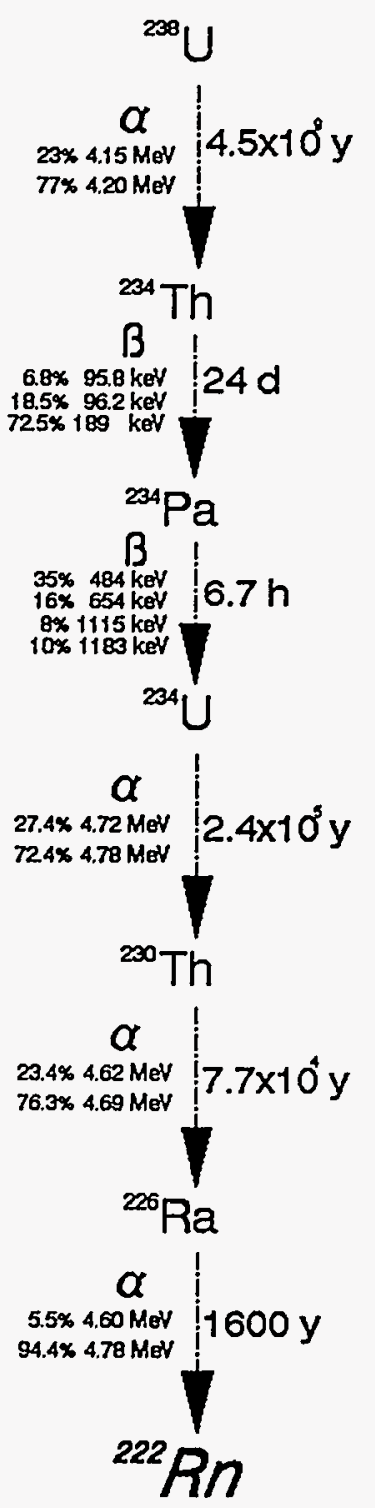

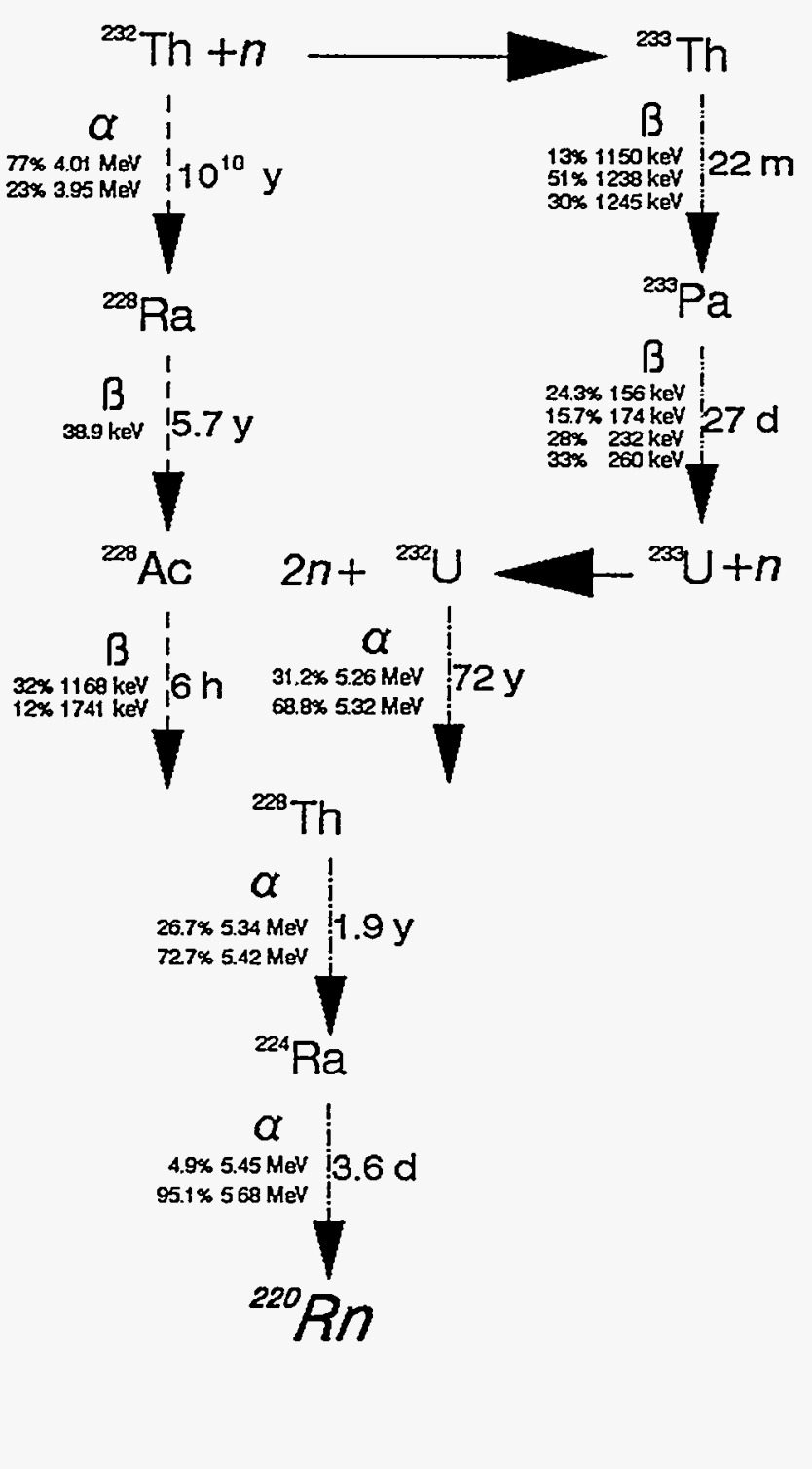
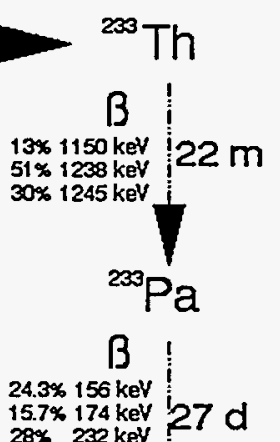

$15.7 \% 174 \mathrm{keV}$

$28 \% \quad 232 \mathrm{keV}$
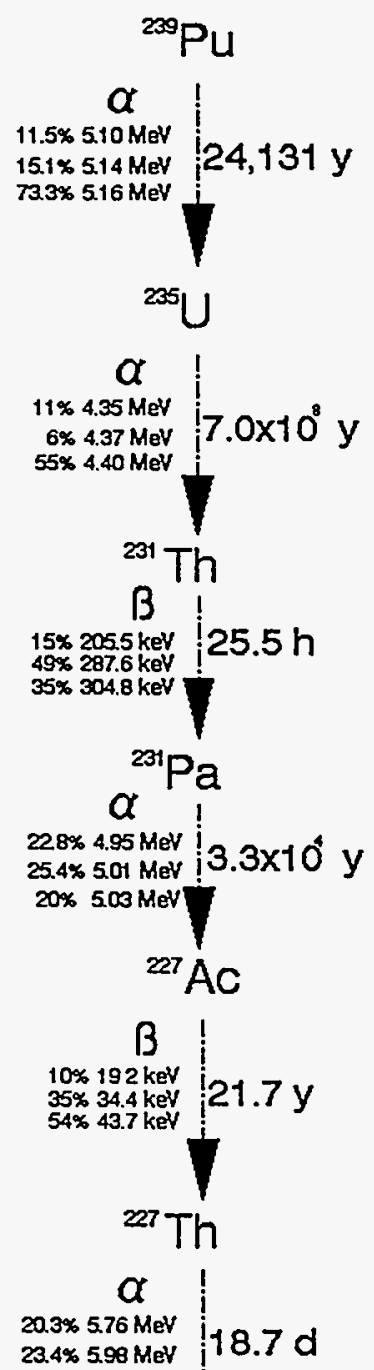
$23.4 \% 5.99 \mathrm{MeV}$
$24.5 \% 6.04 \mathrm{MeV}$
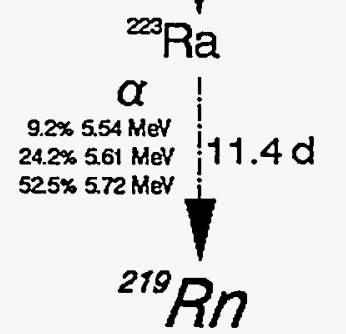


\section{Figure 3. Decay of Radon, Thoron \& Actinon}
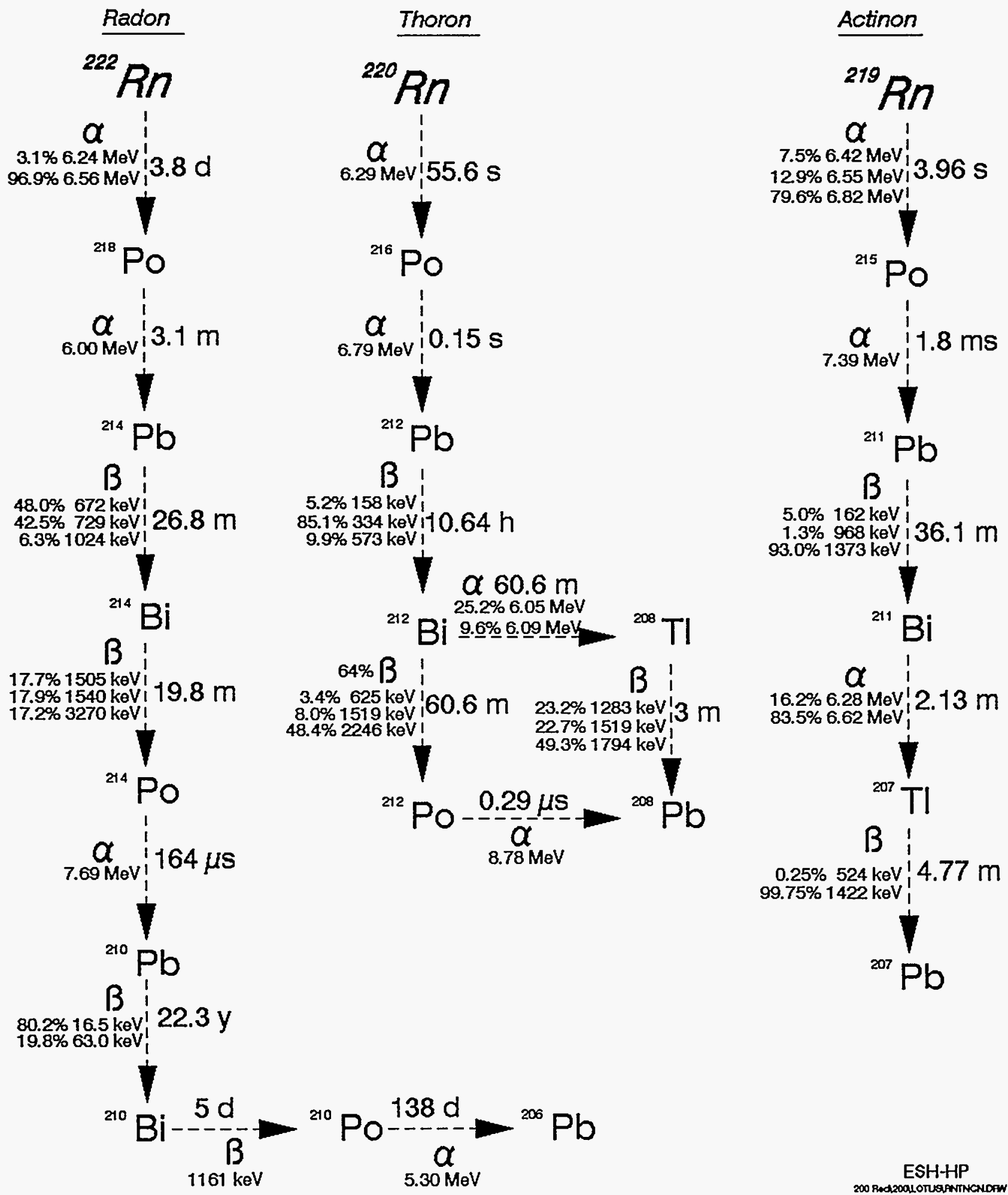

$0.25 \% 524 \mathrm{kev}$; $4.77 \mathrm{~m}$

ESH+HP 200 RadzOOLOTUSANTICNOAN 


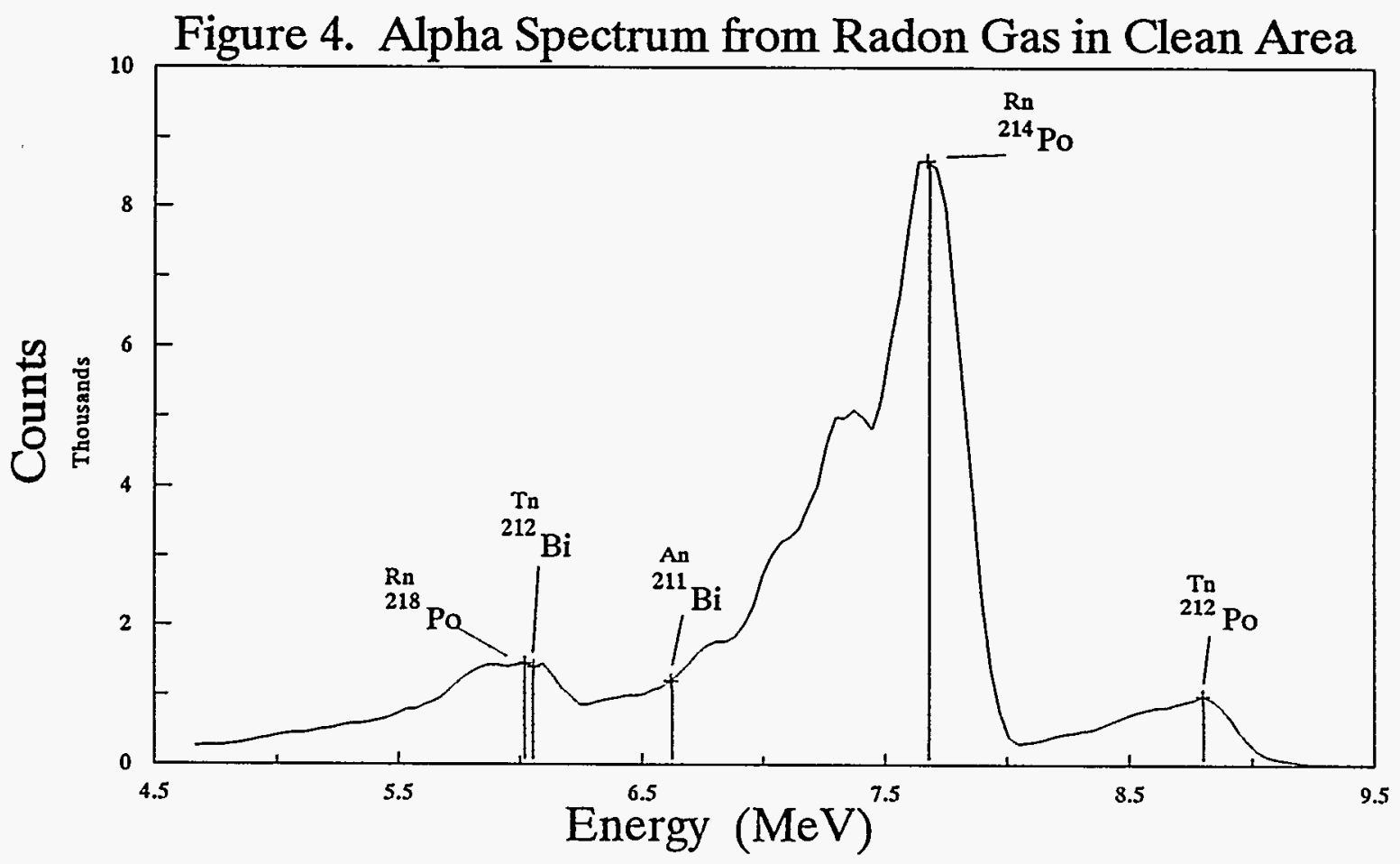

Figure 5. Alpha-6 Rn \& Tn Activities in Clean Area

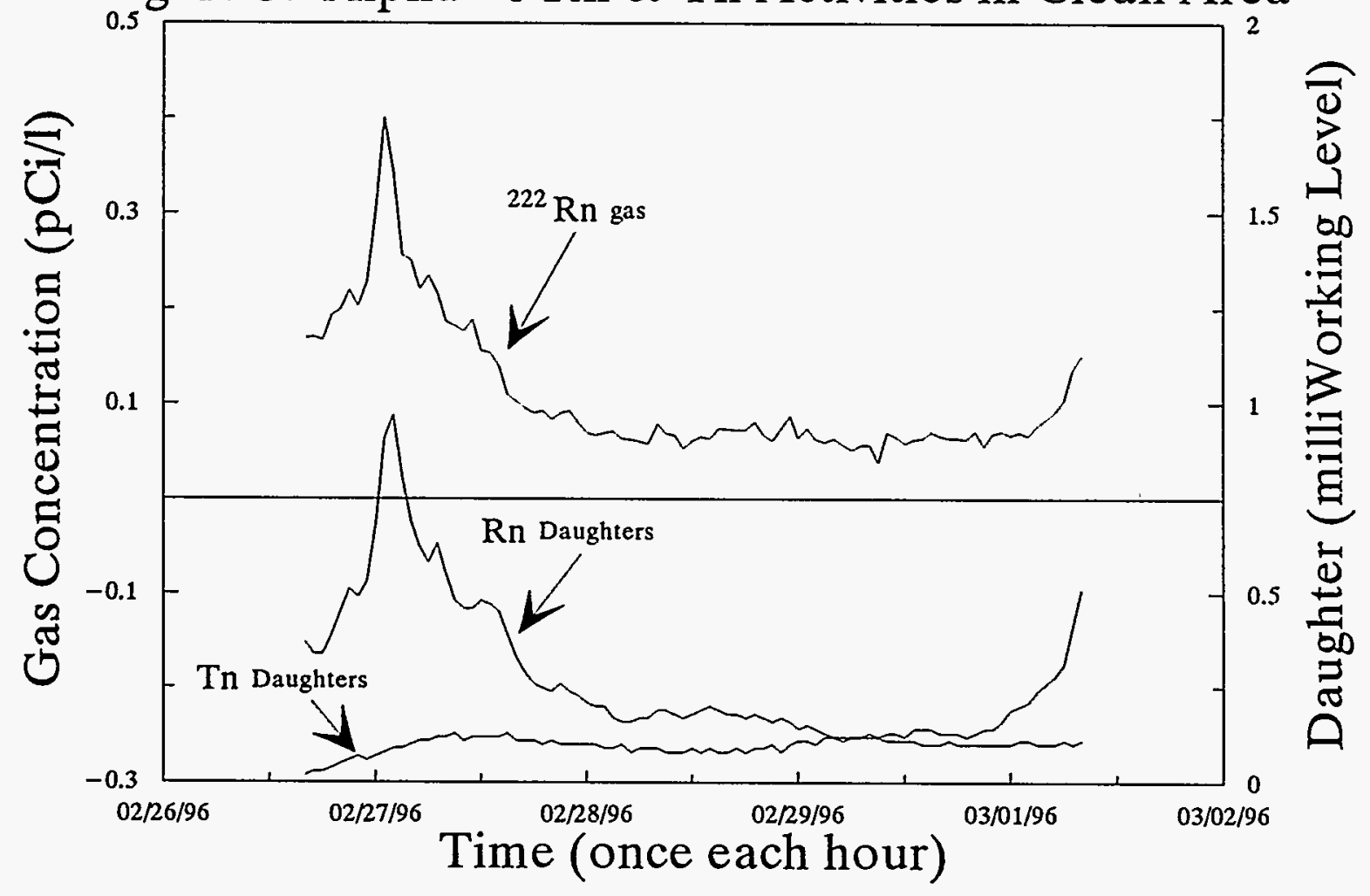



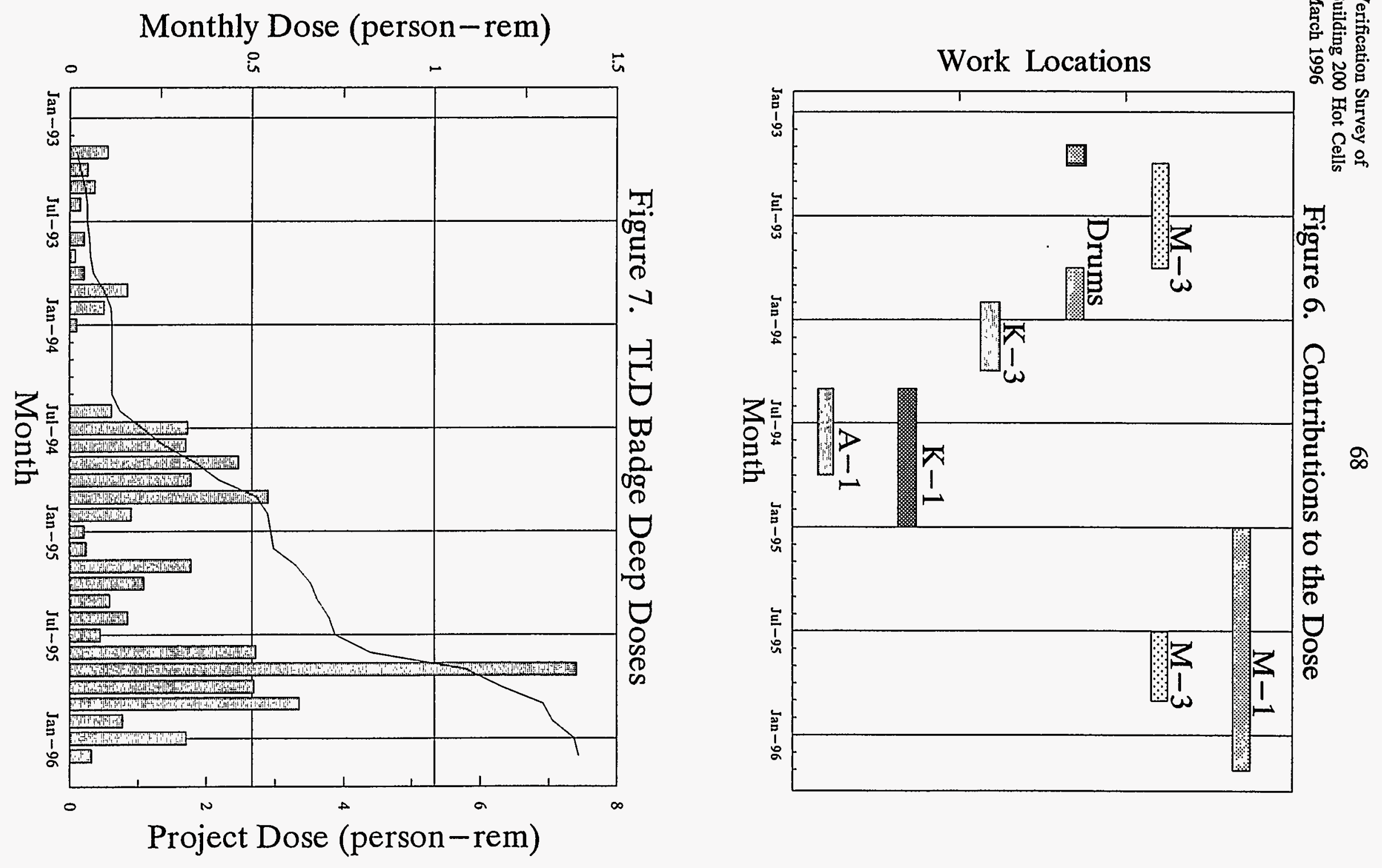
Verification Survey of Building 200 Hot Cells

March 19968
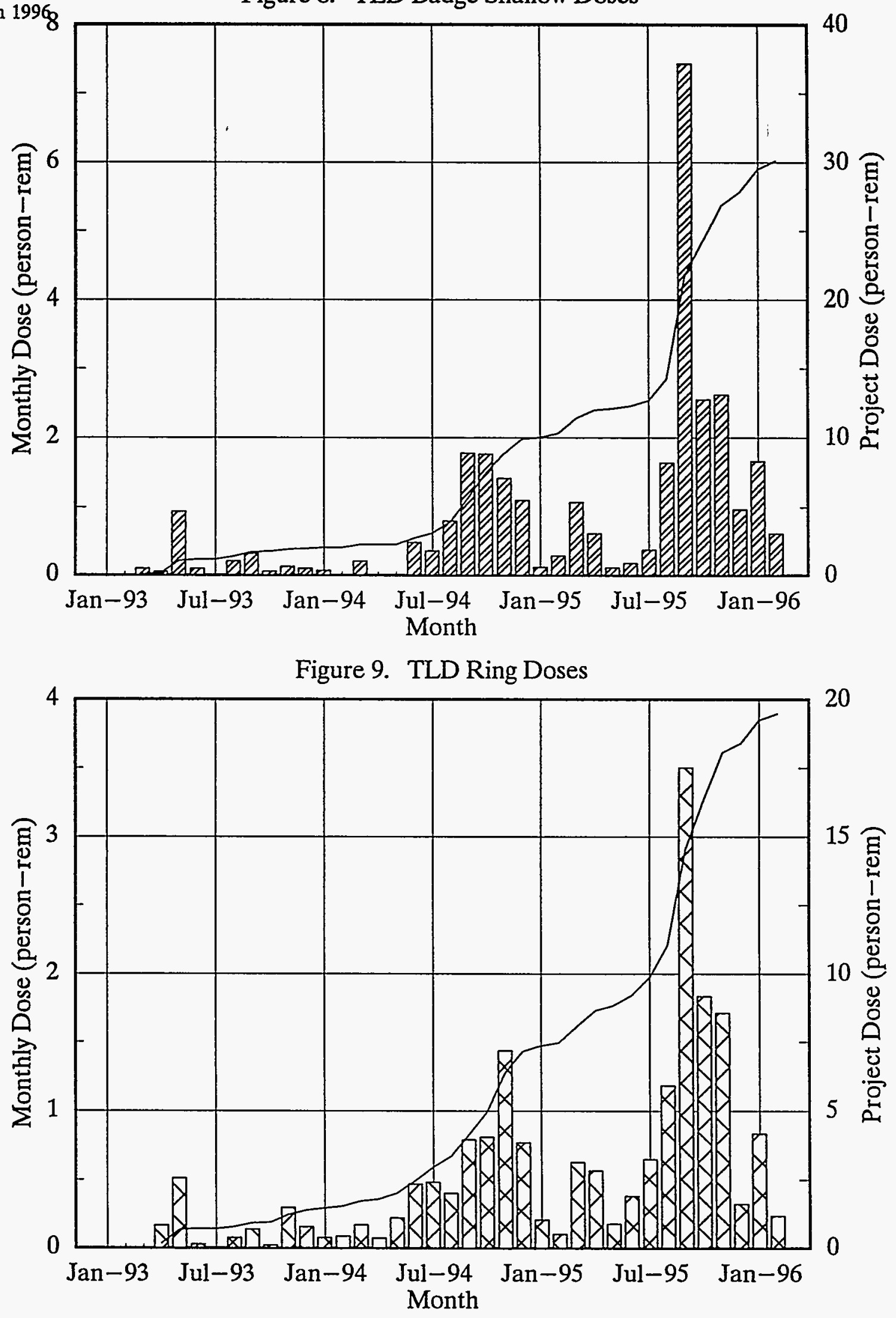

Figure 9. TLD Ring Doses

Figure 8. TLD Badge Shallow Doses

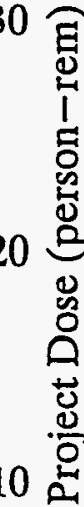

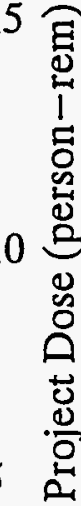


Figure 10. Quarterly Rn-220 Emissions from Cell K-1; 1984 to 1996

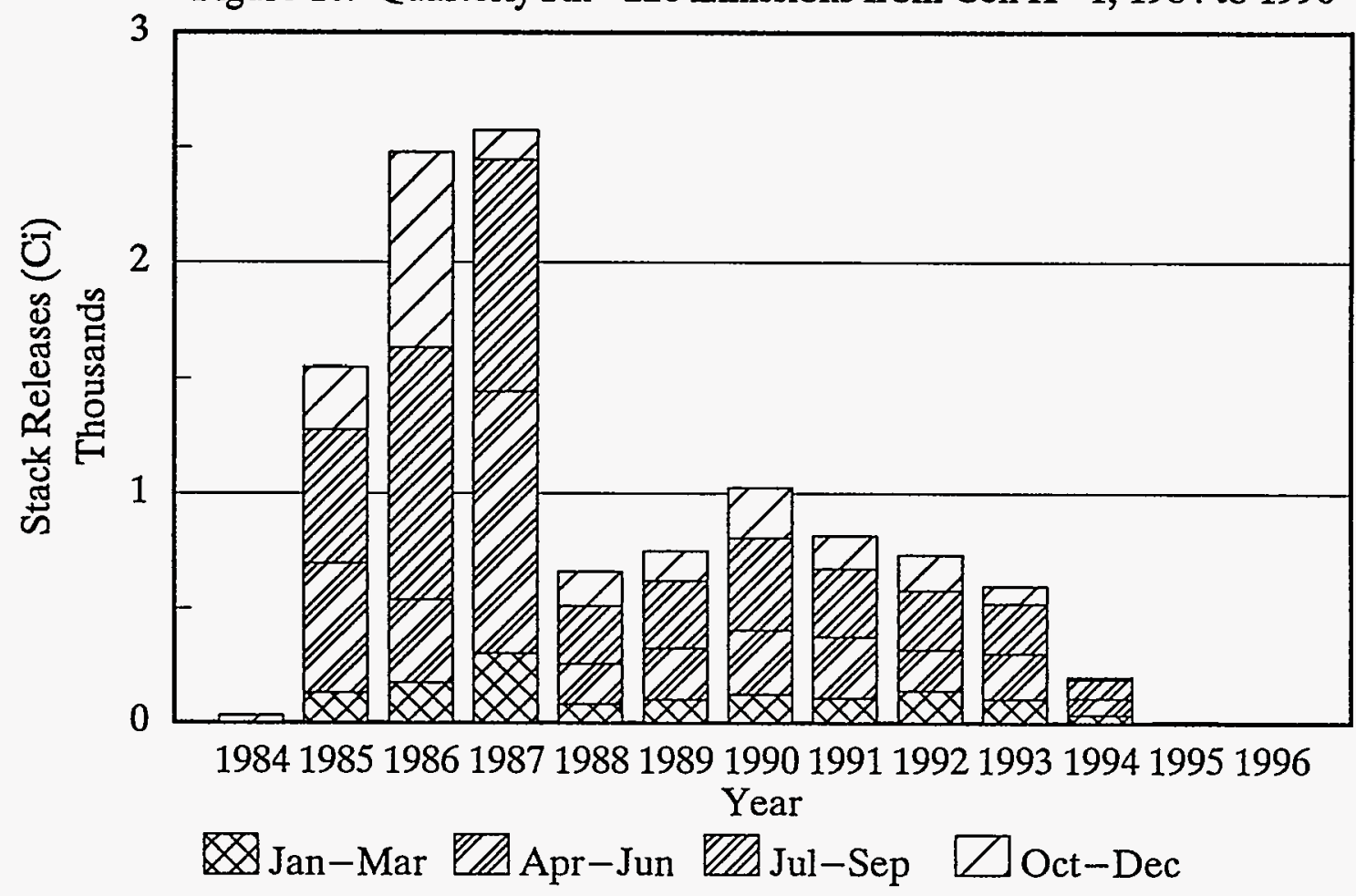

Figure 11. Quarterly Rn-220 Emissions from Cell K-1; 1988 to 1996

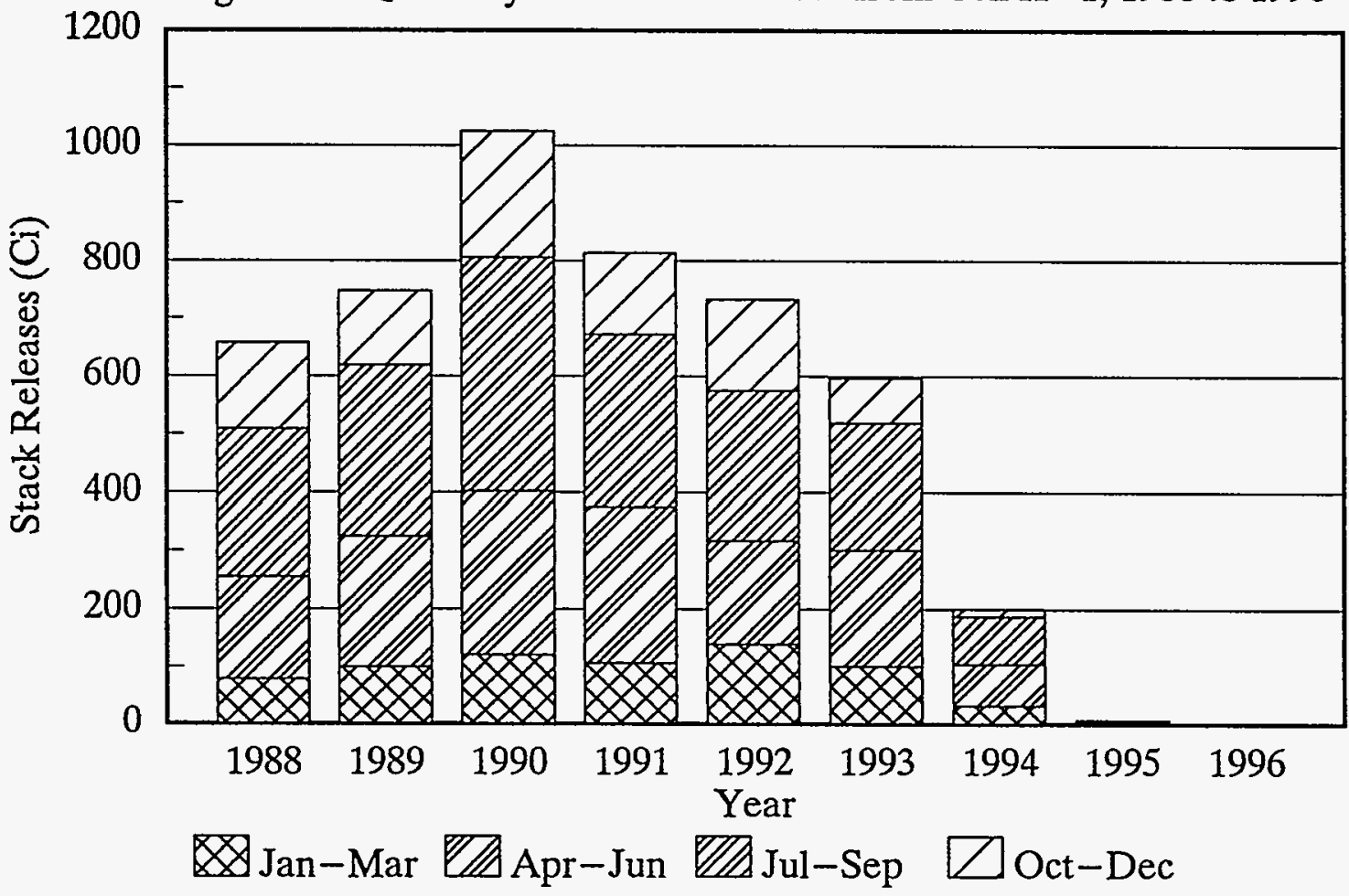


Verification Survey of

Building 200 Hot Cells

March 1996

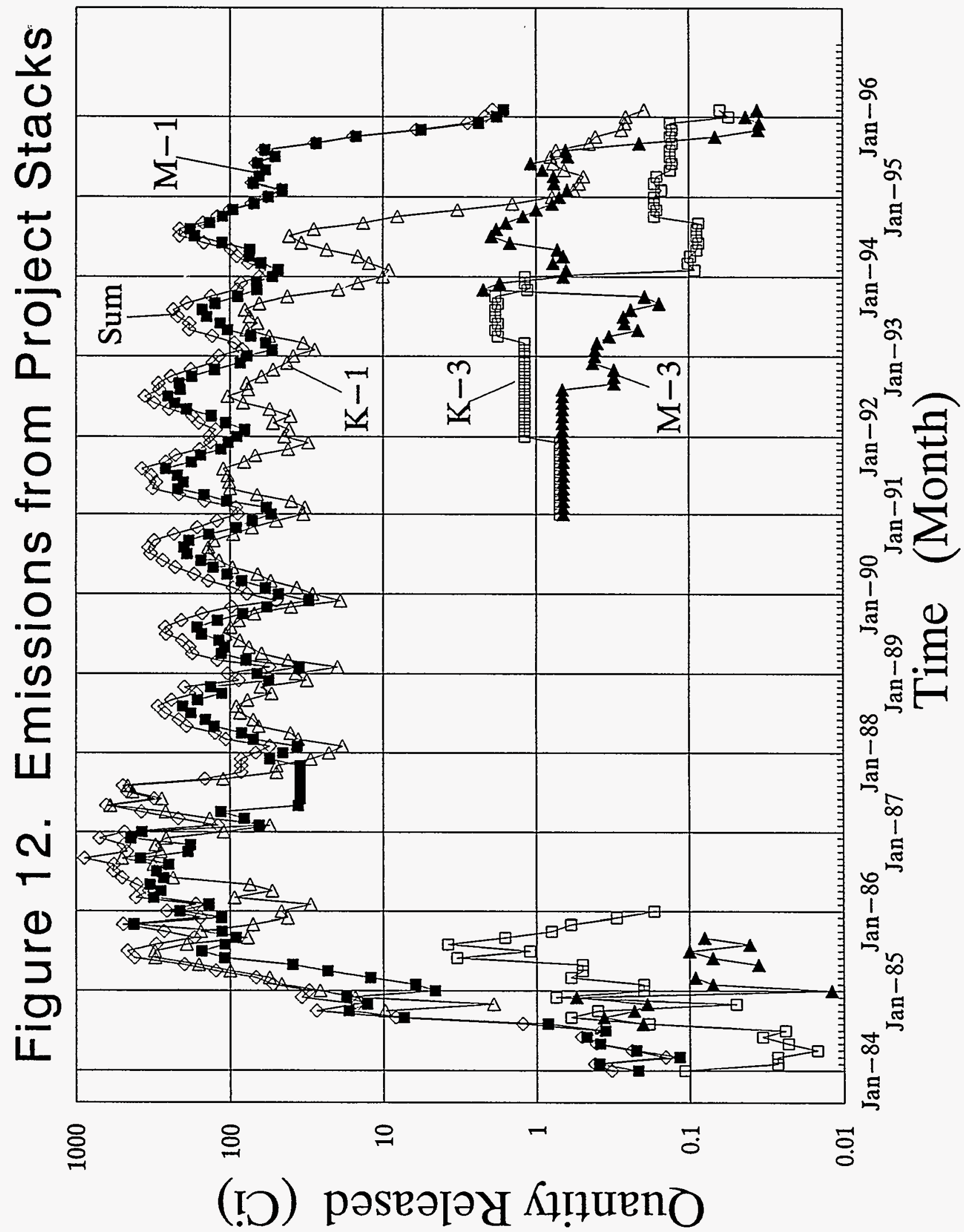


Figure 13. Qurterly Rn-220 Emissons from Cell K-3

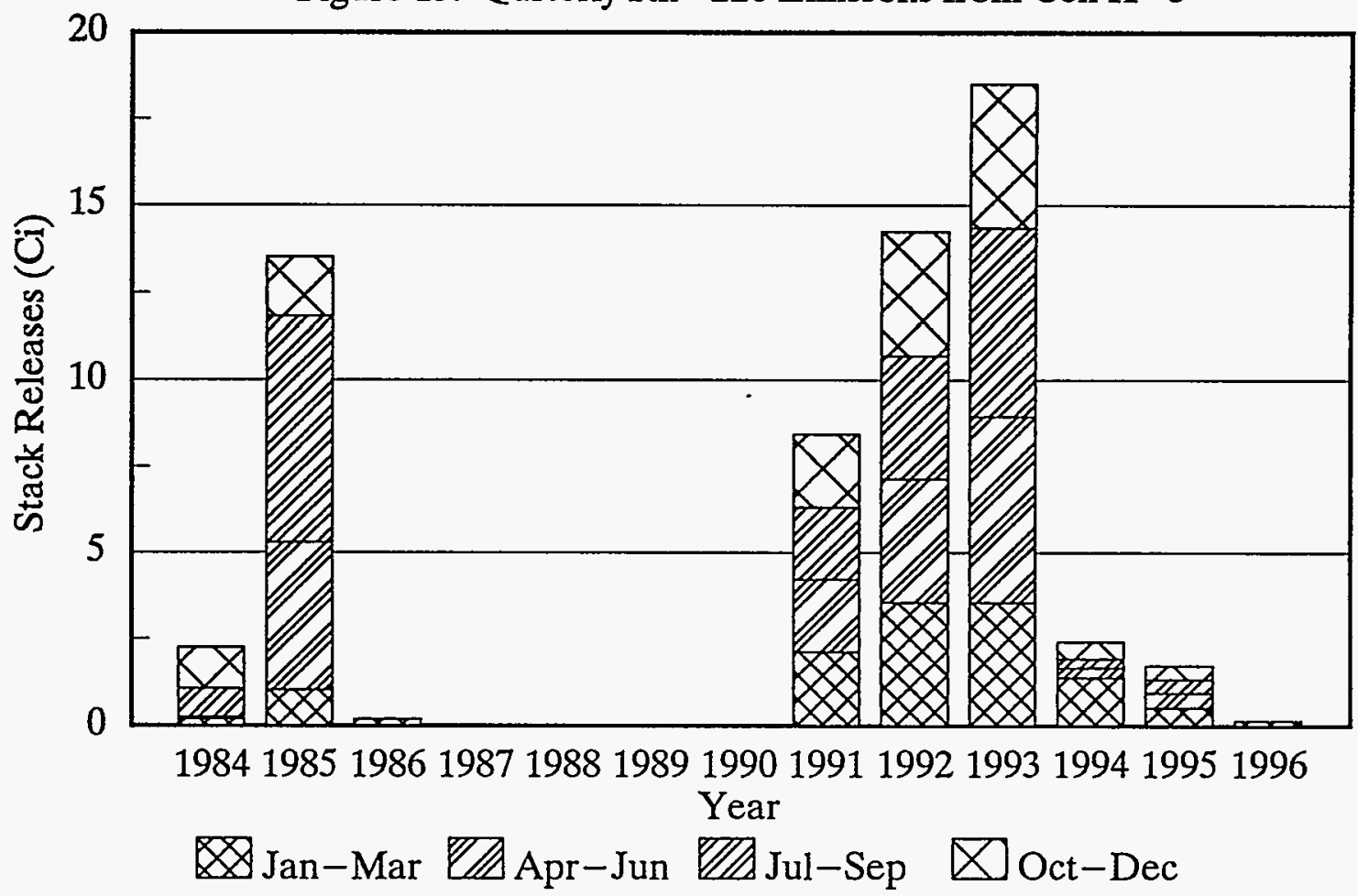

Figure 14. Quarterly $\mathrm{Kr}-85$ and $\mathrm{Rn}-220$ Emissons from Cell $\mathrm{M}-3$

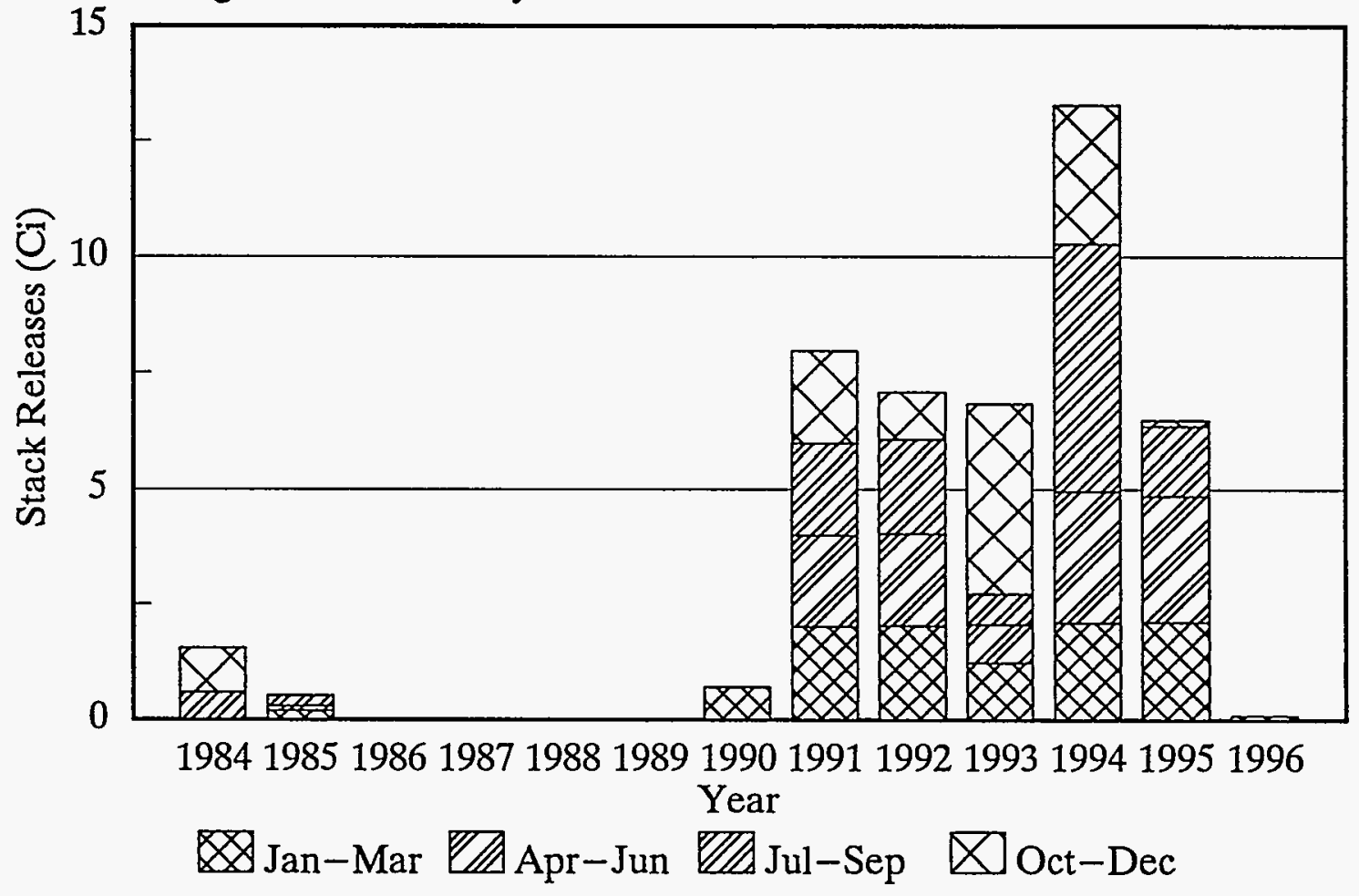


Figure 15. Quarterly Rn-220 Emissions from Cell M-1; 1984 to 1996

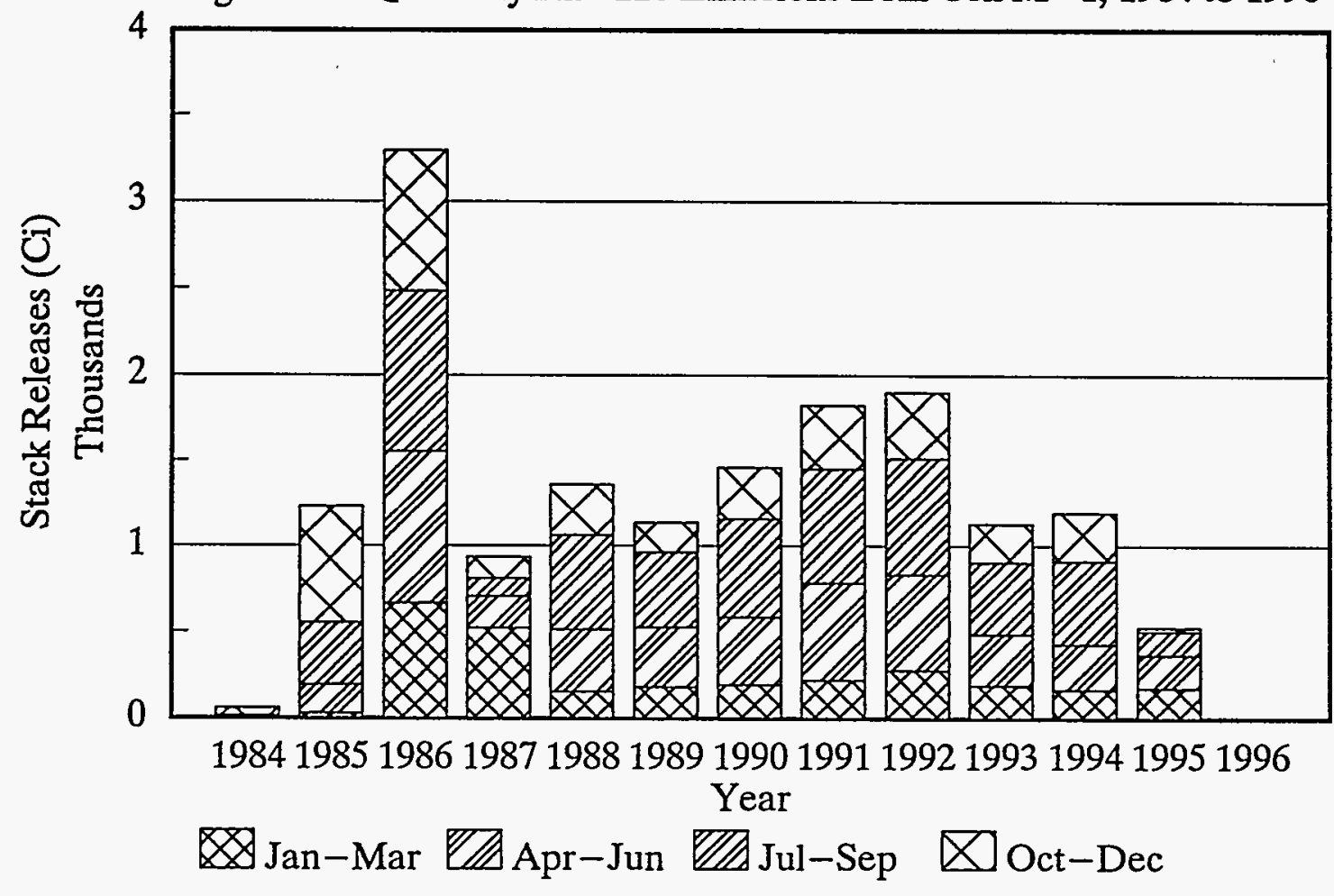

Figure 16. Quarterly Rn-220 Emissions from Cell M-1; 1987 to 1996

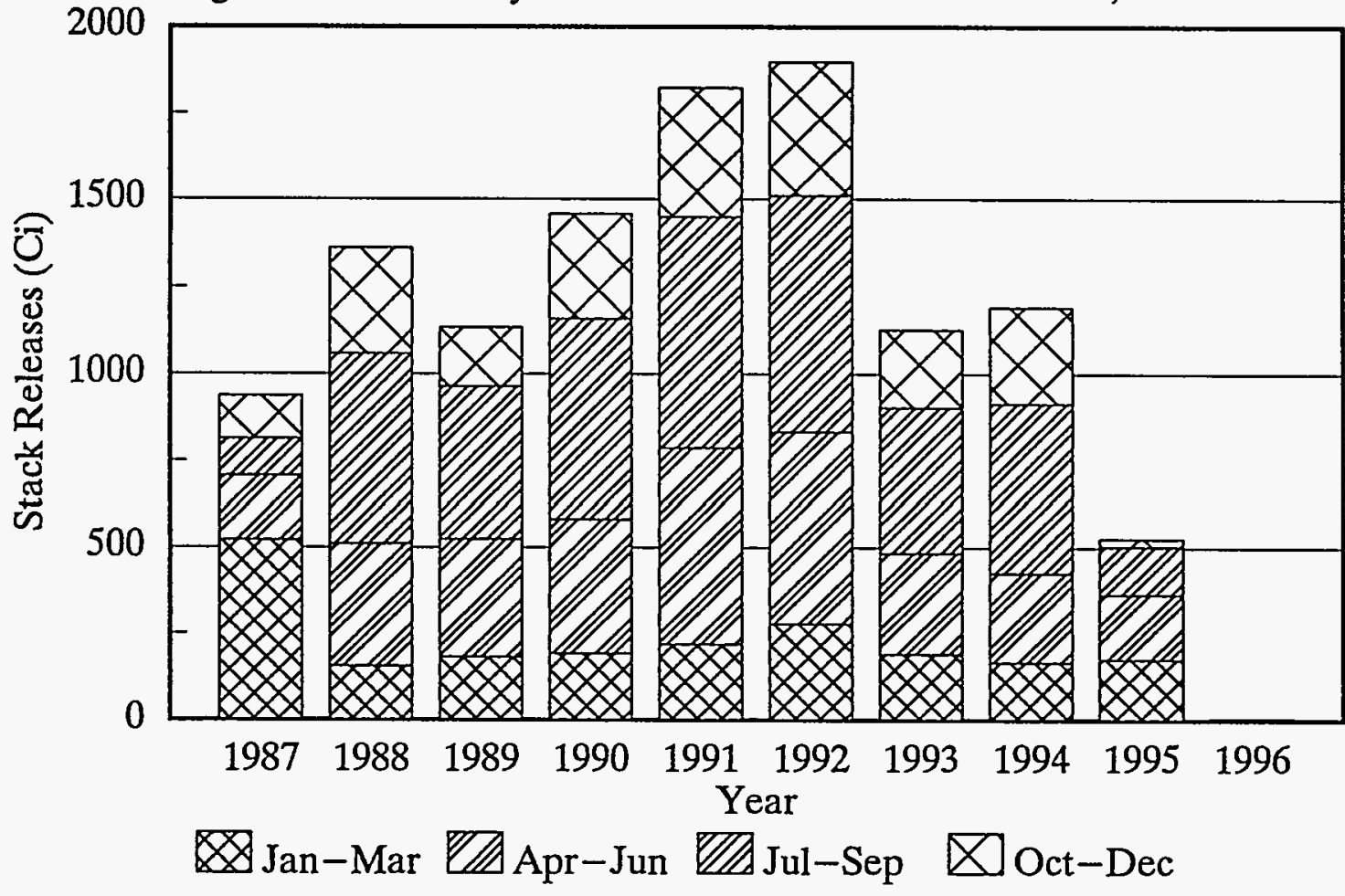


Verification Survey of

Building 200 Hot Cells

March 1996
A1

APPENDIX A. Cell A-1 Figures 


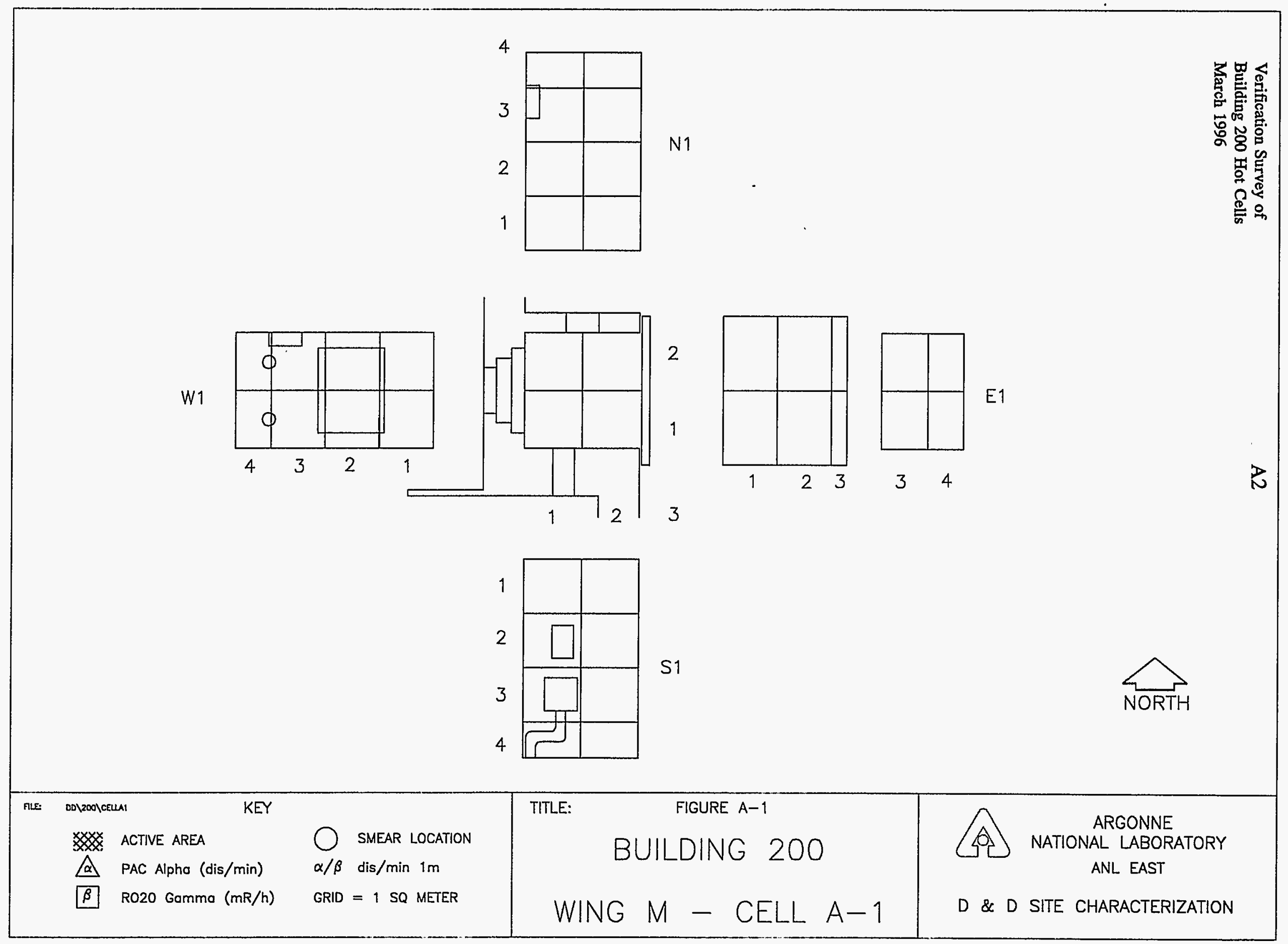




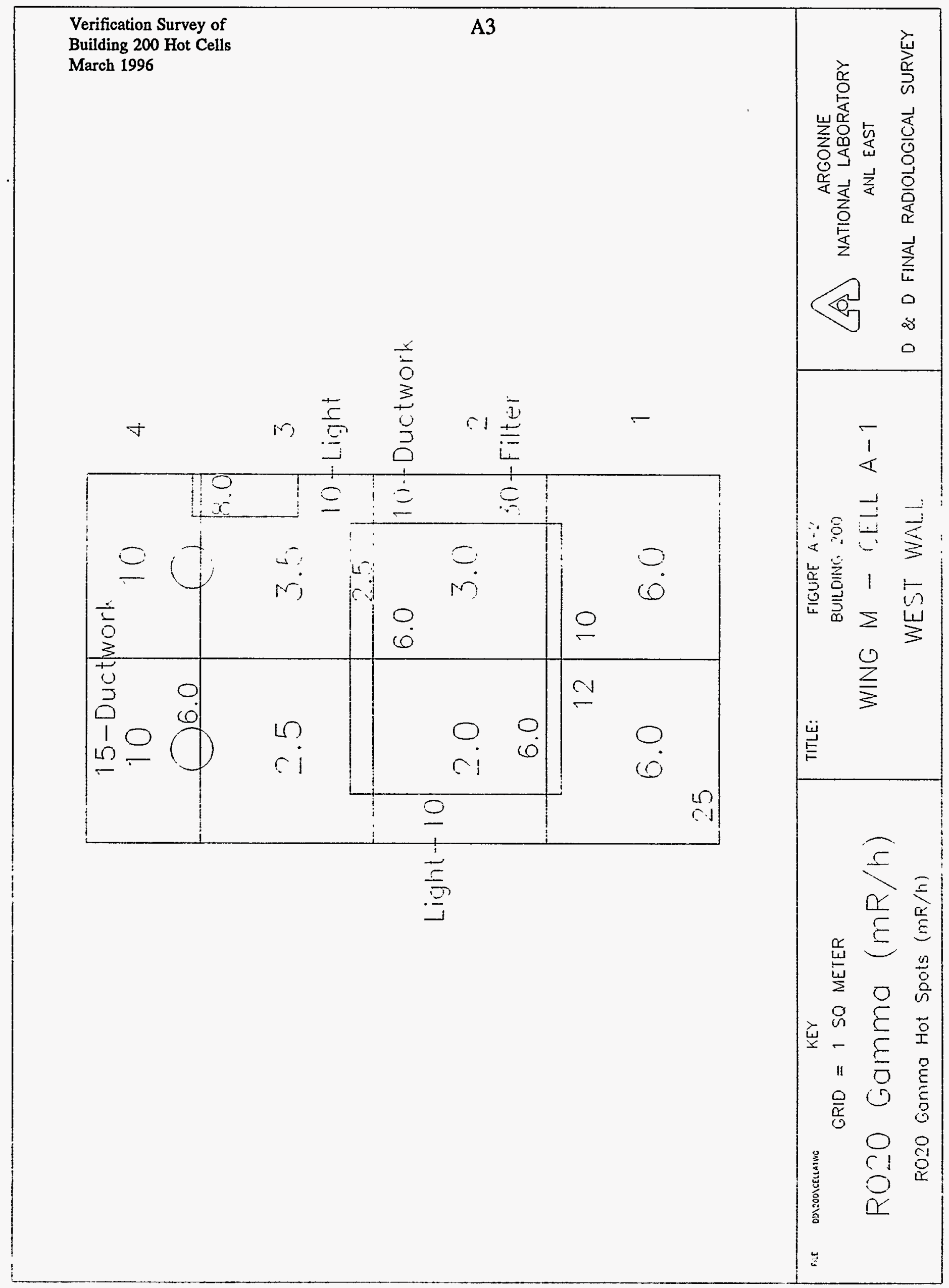




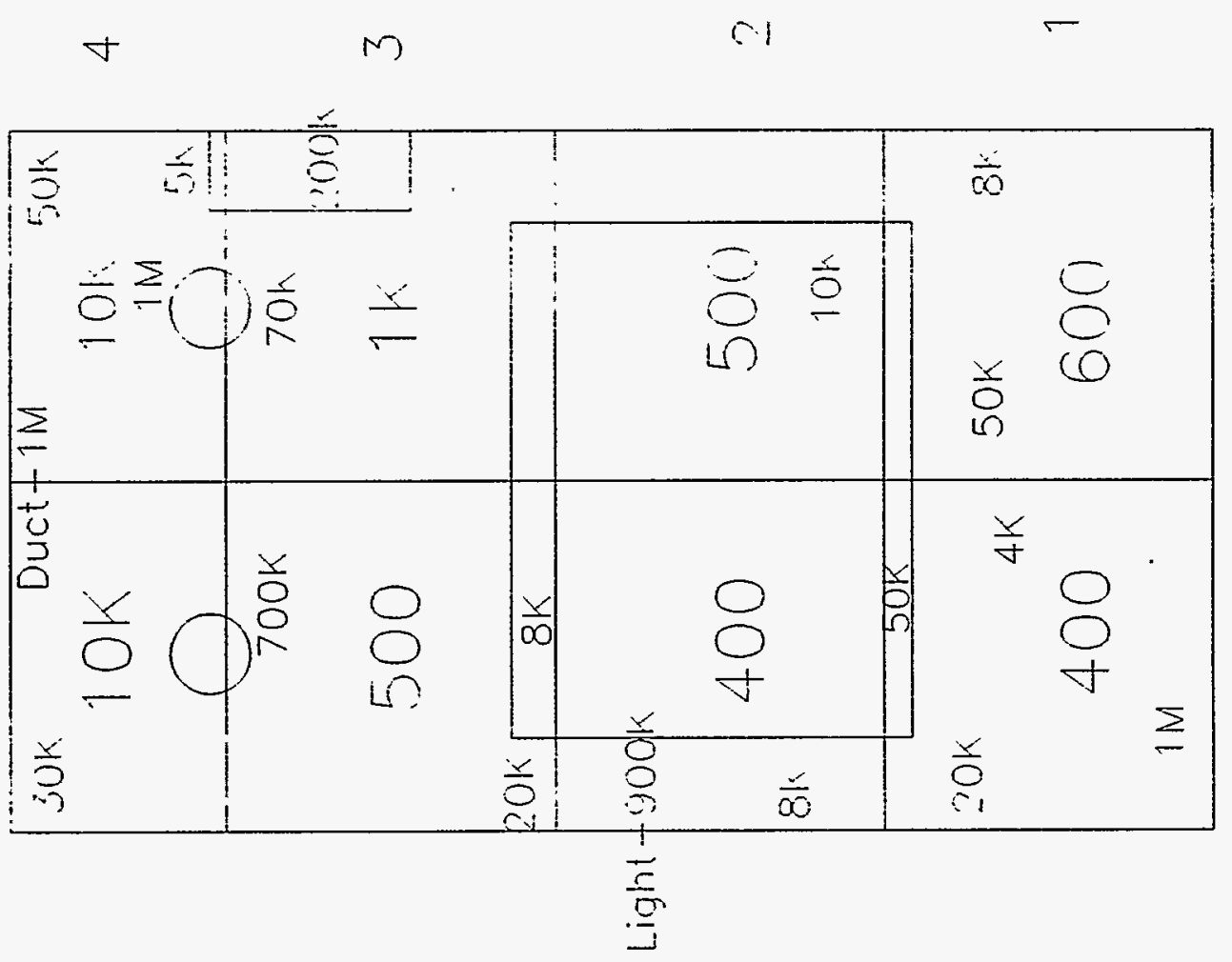




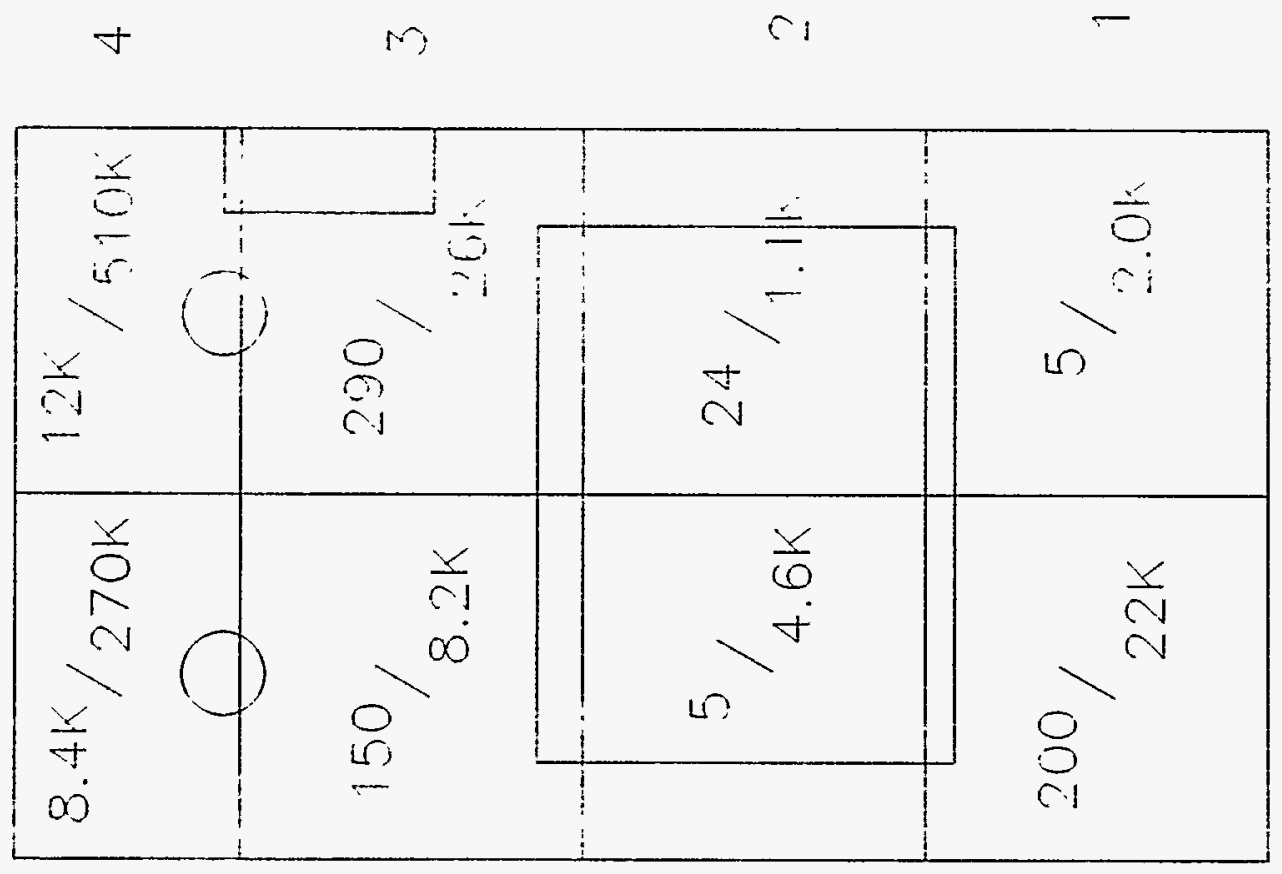




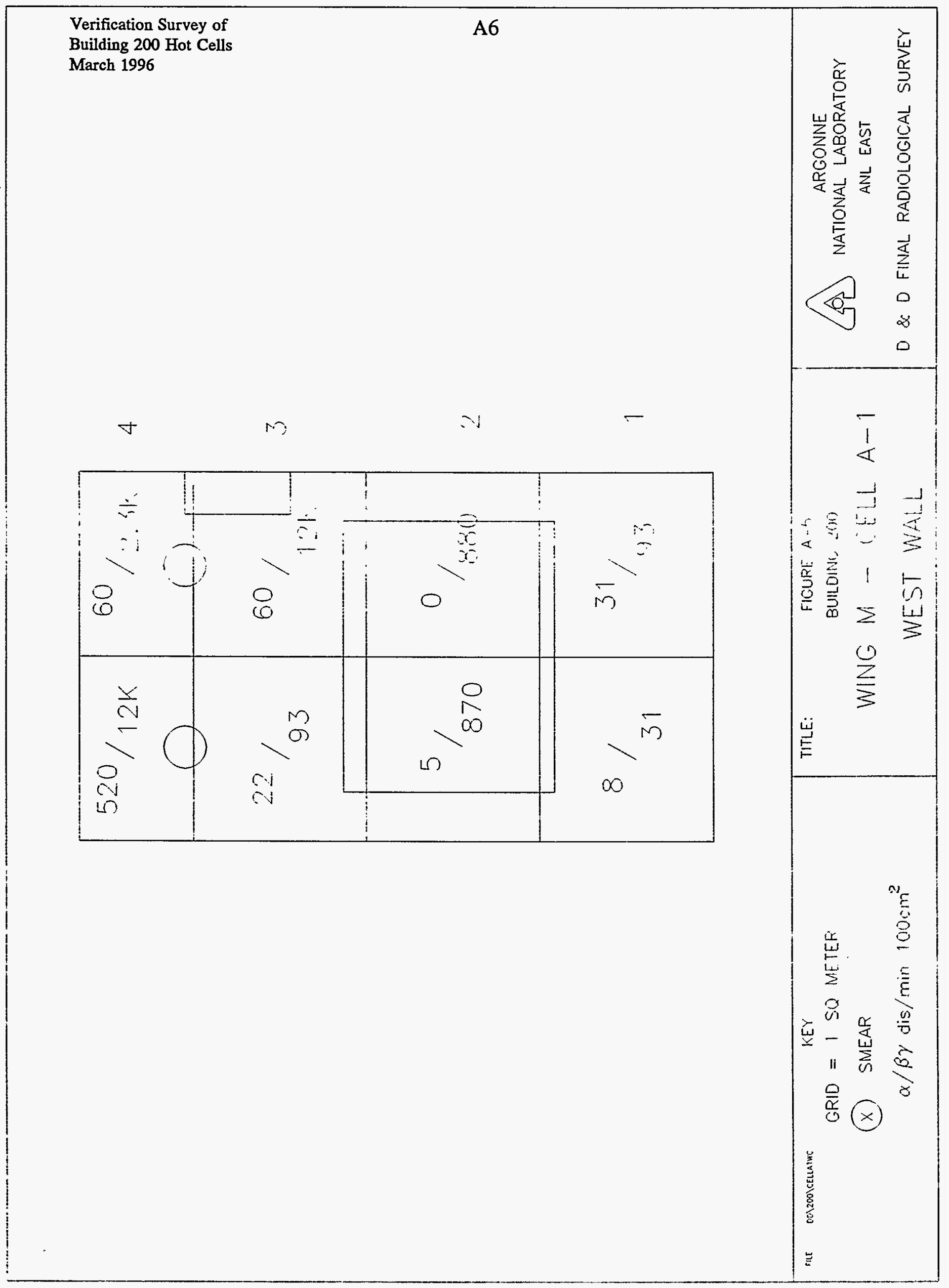




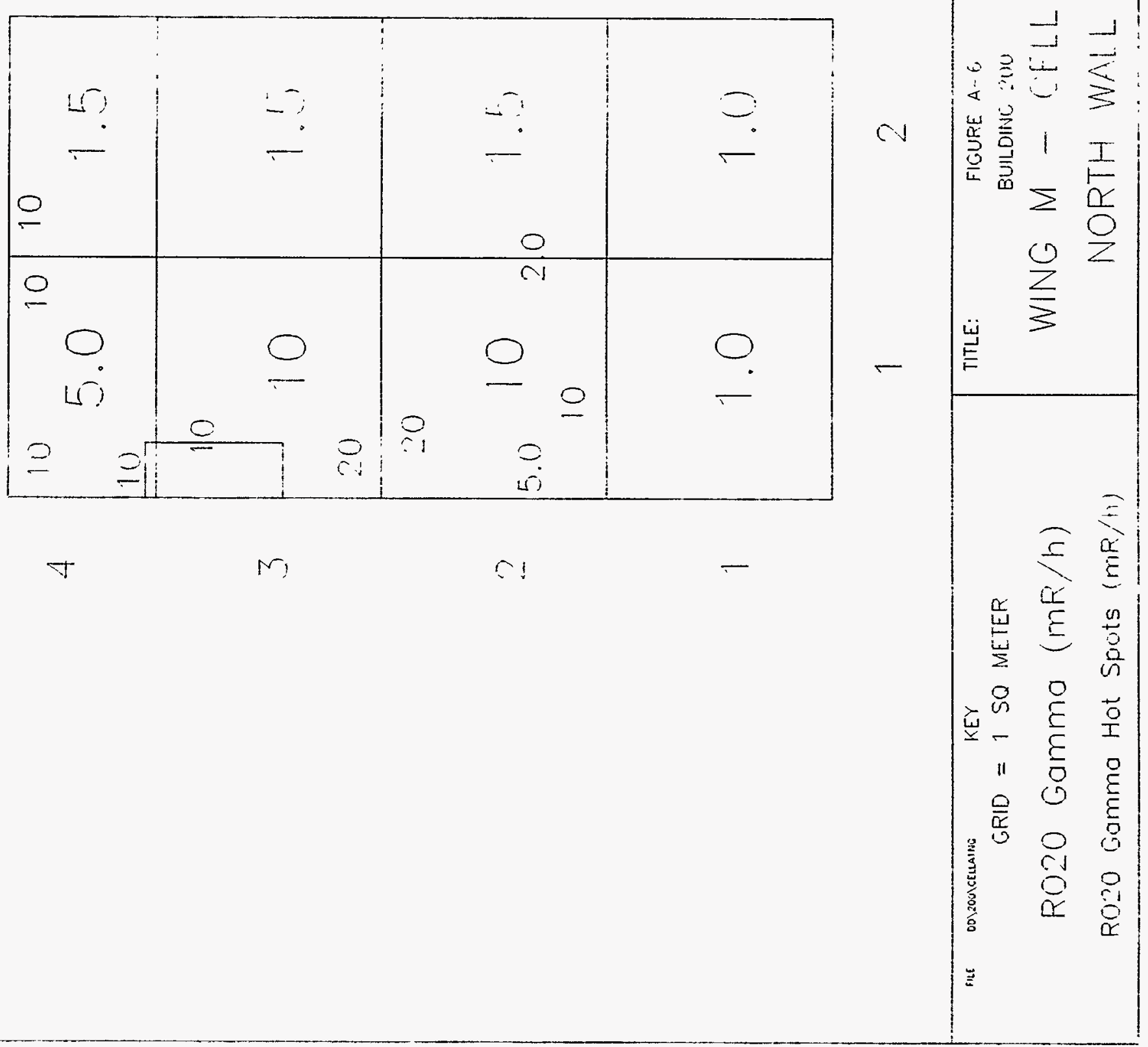




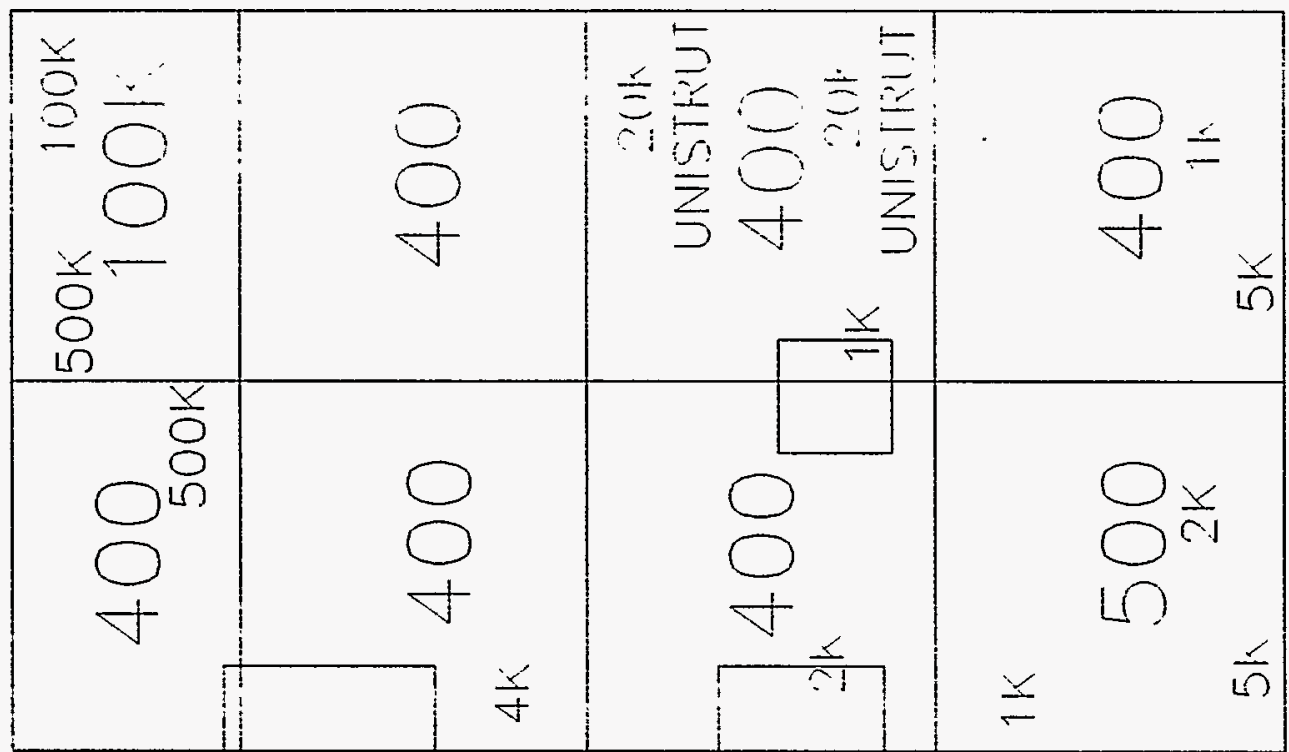

\section{N}

$\begin{array}{llll}0 & 8 & 1 \\ i & 0 & 1 \\ 4 & 0\end{array}$

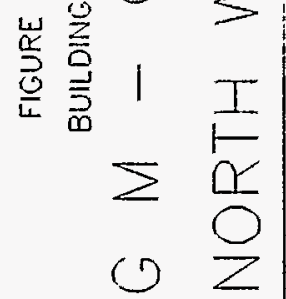

状 $\geqq$

$\nabla$

N

6.1 


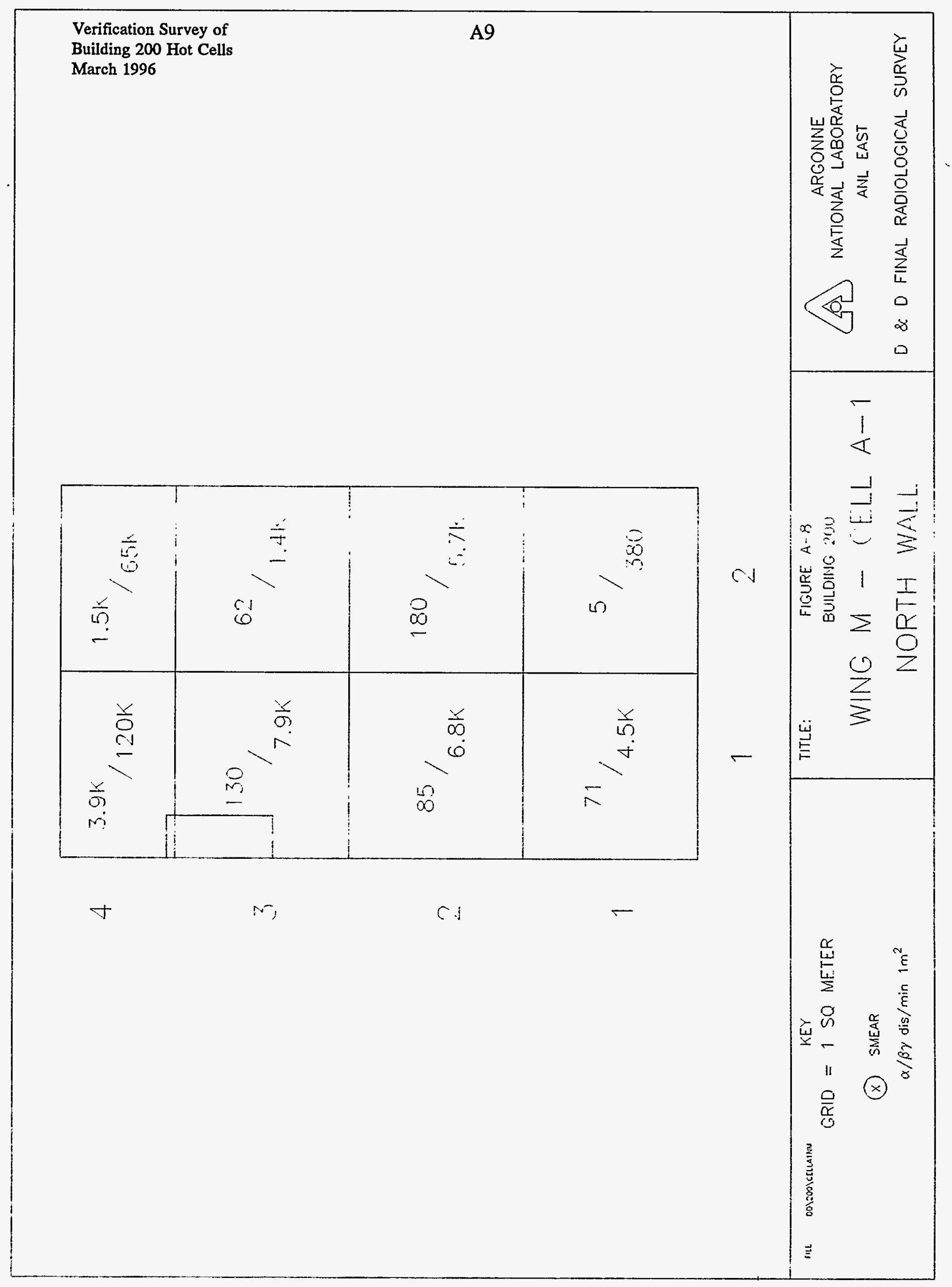


Verification Survey of

Building 200 Hot Cells

March 1996
A10
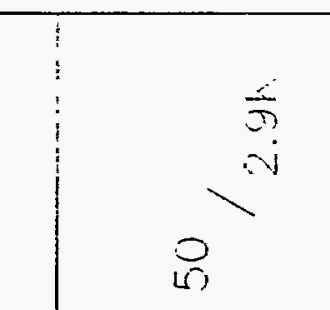

$\frac{10}{2}$

$\frac{\dot{x}}{x}$

$>$

$0_{0}^{\circ} \quad 5$

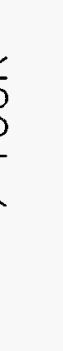

$\nabla$

0

M

6

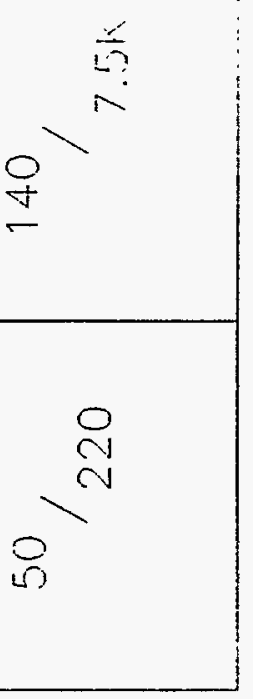

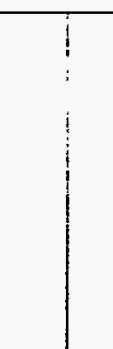

$M$ $\frac{5}{5}$<smiles>CC</smiles>

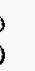

0
0

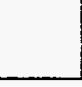

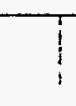
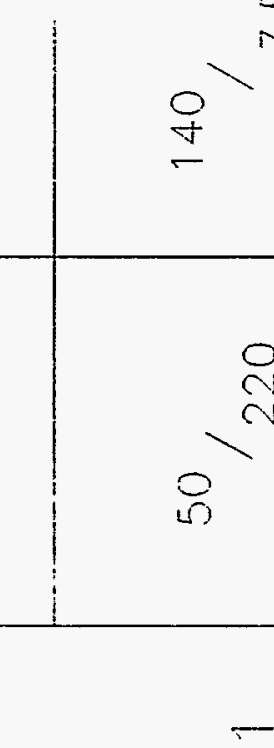

$c$

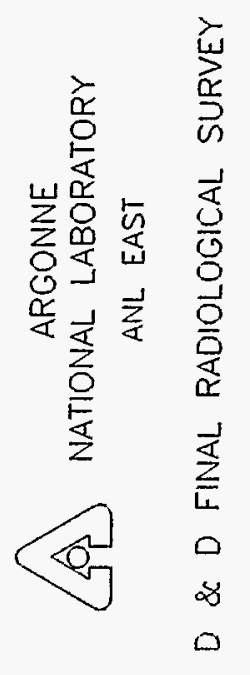

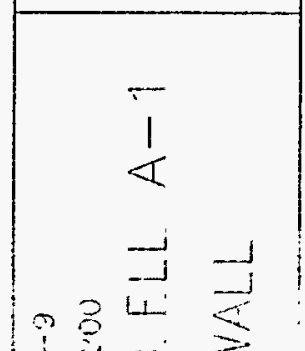

¿

崖总

$1 I$

$\geq \stackrel{9}{2}$

$\geqq$

芦

$\leftarrow$

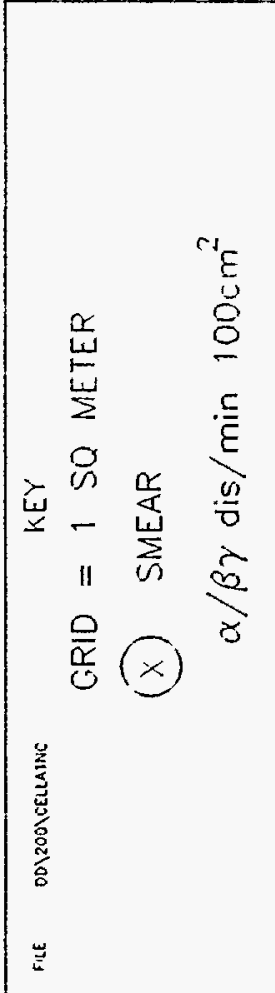




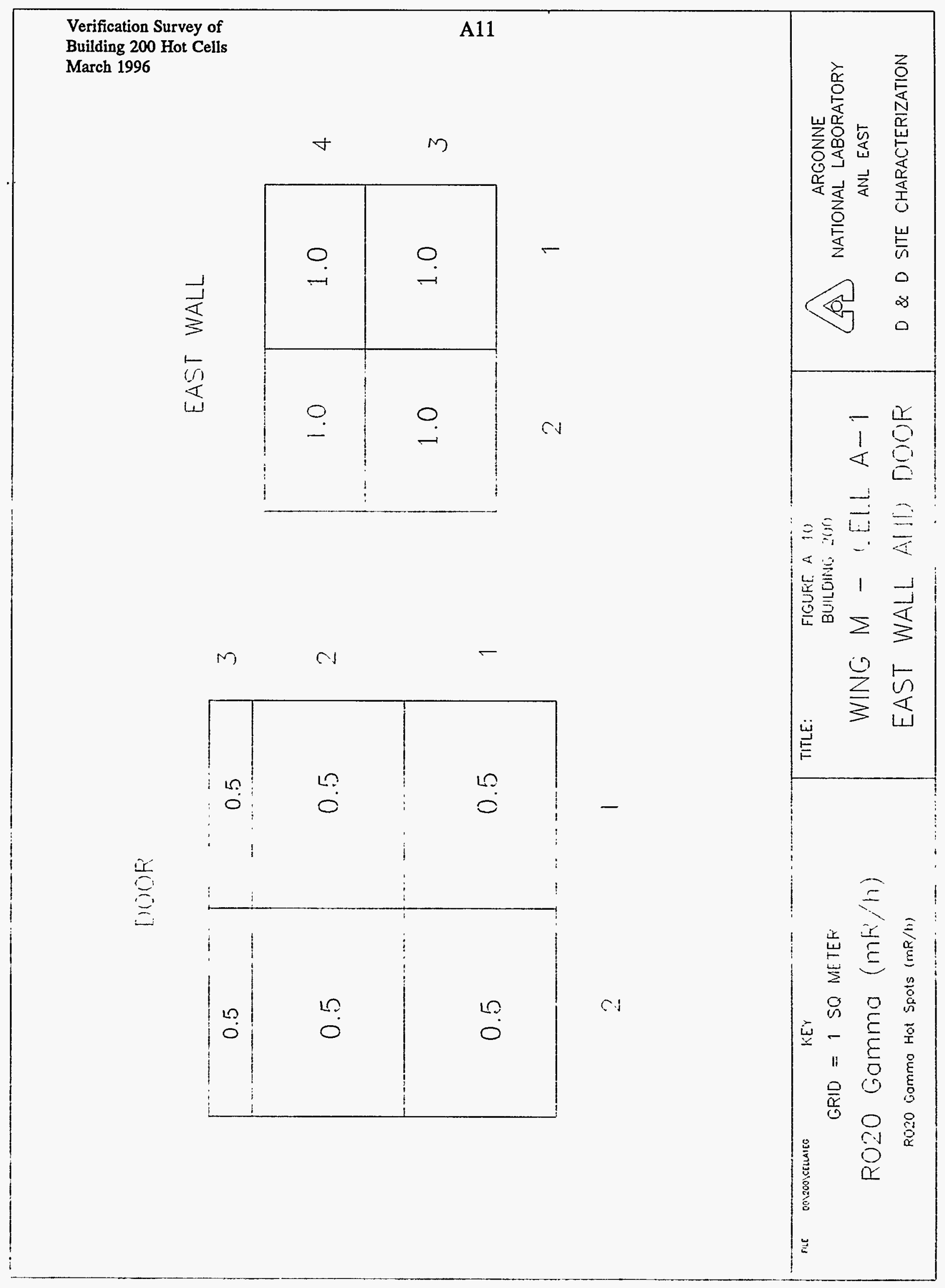


Verification Survey of

Building 200 Hot Cells

March 1996

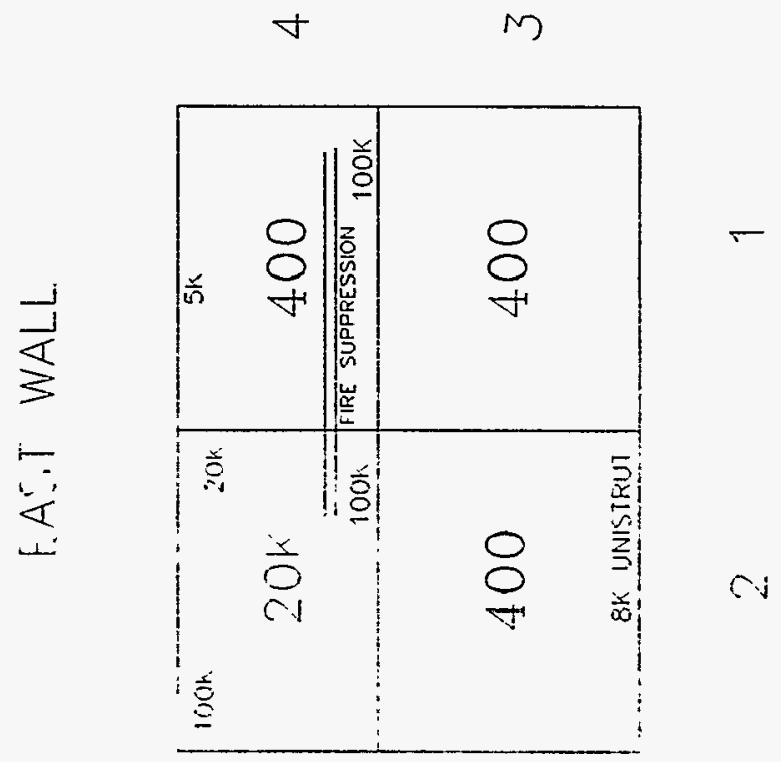

$M$

$\curvearrowright$

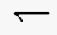

$y$
$\Xi$

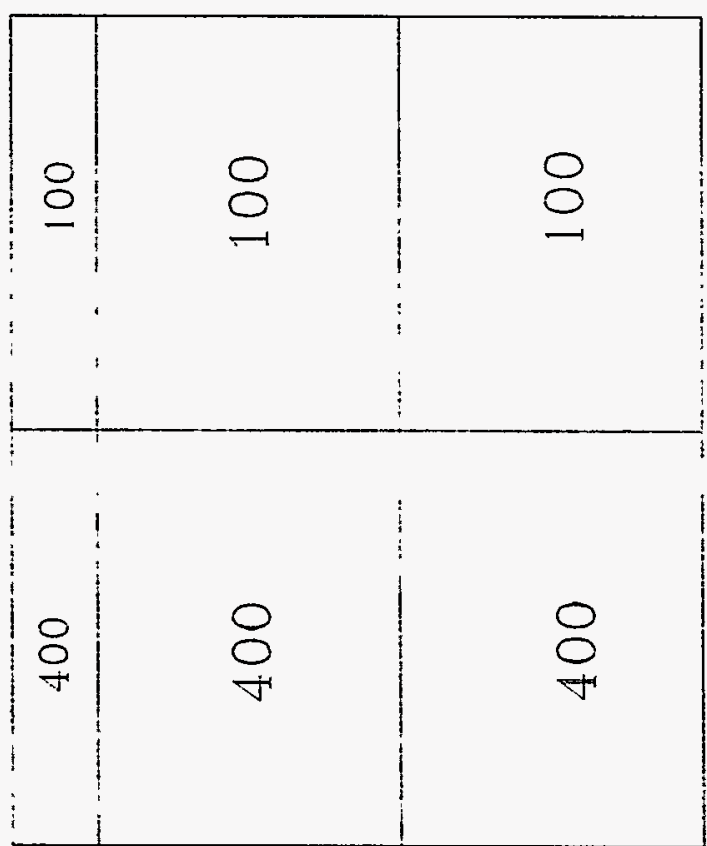

A12

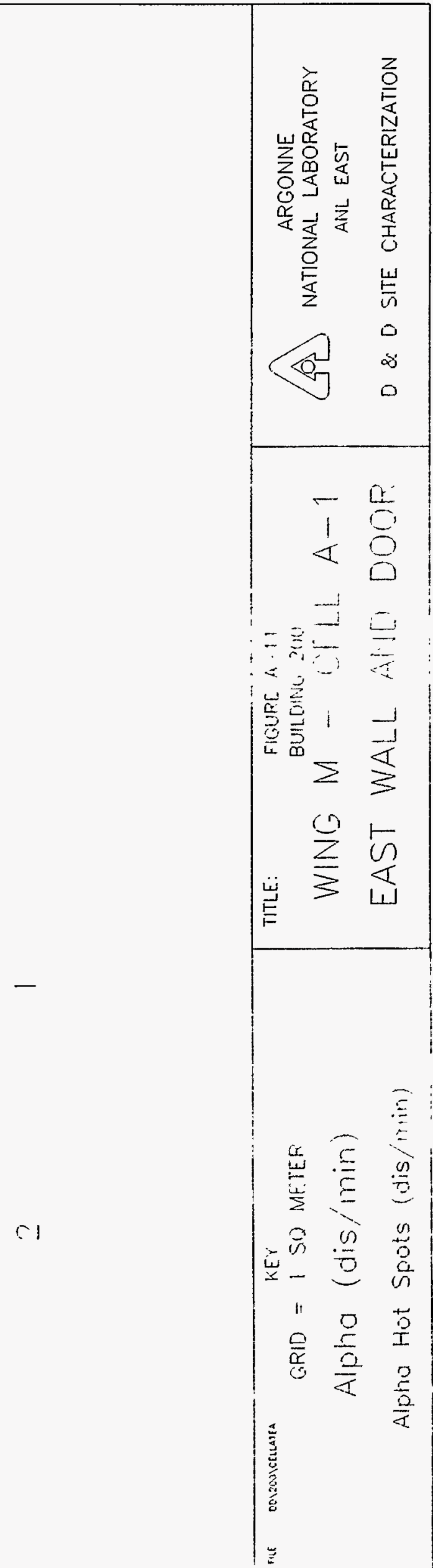




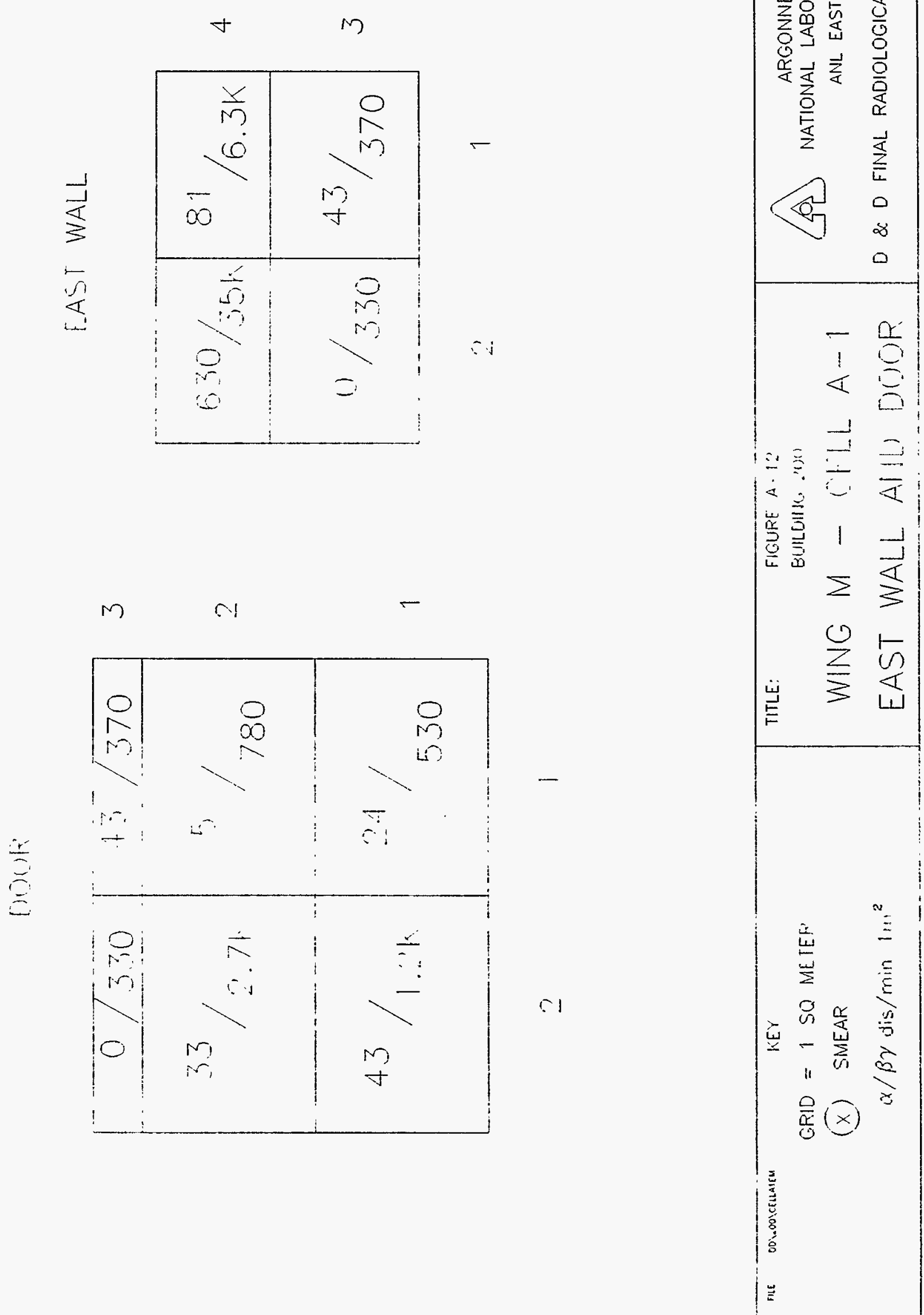




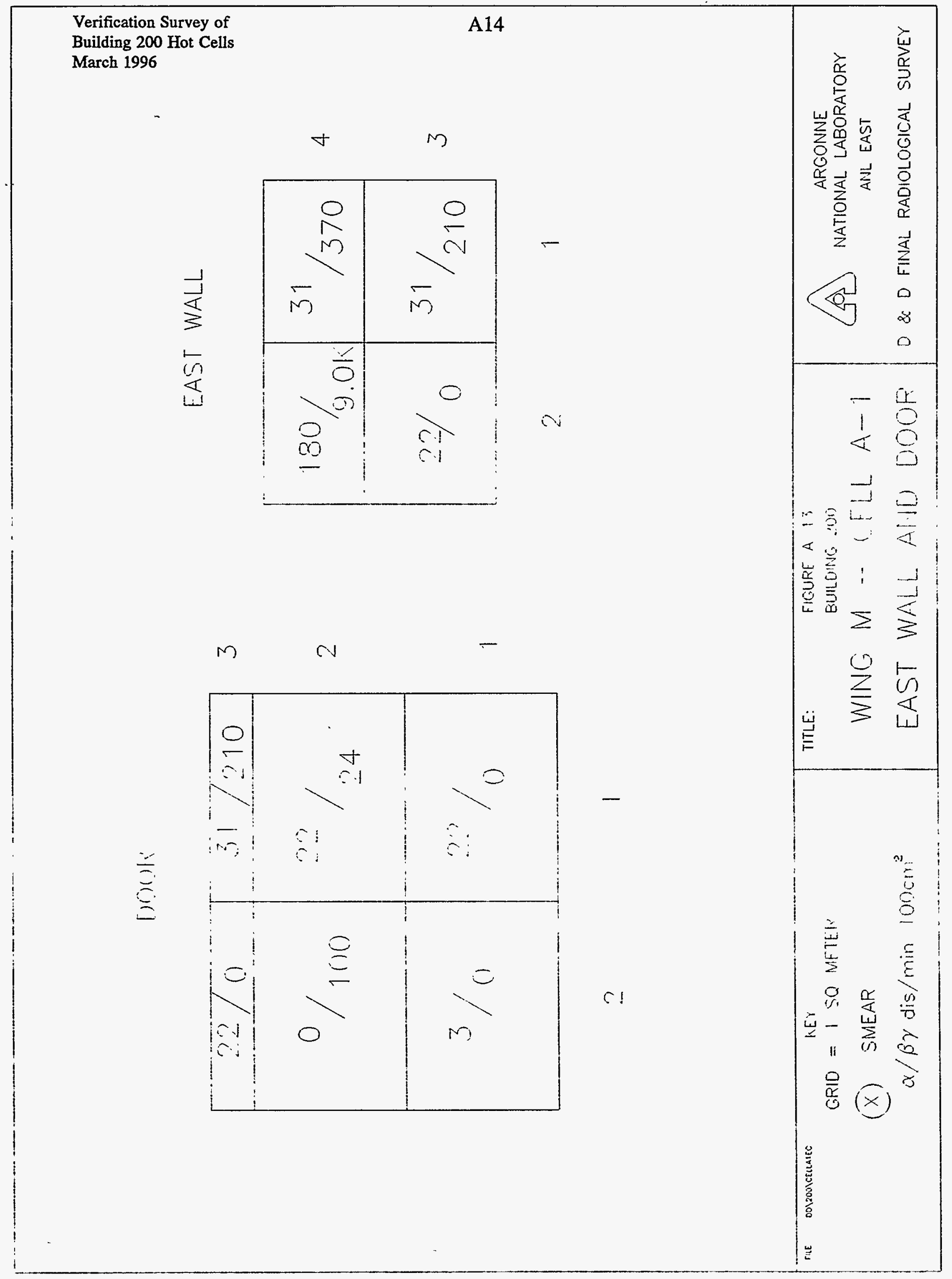




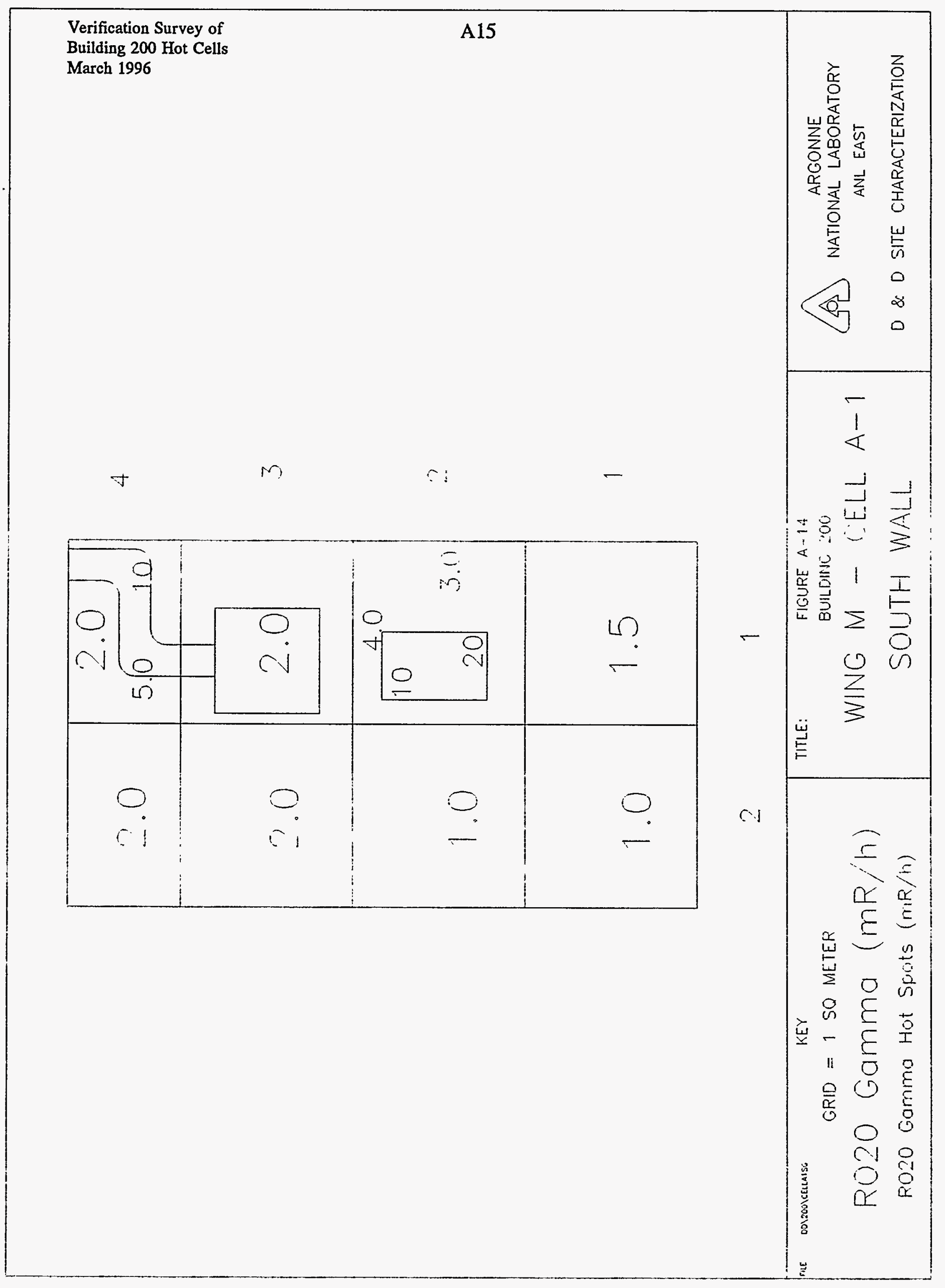




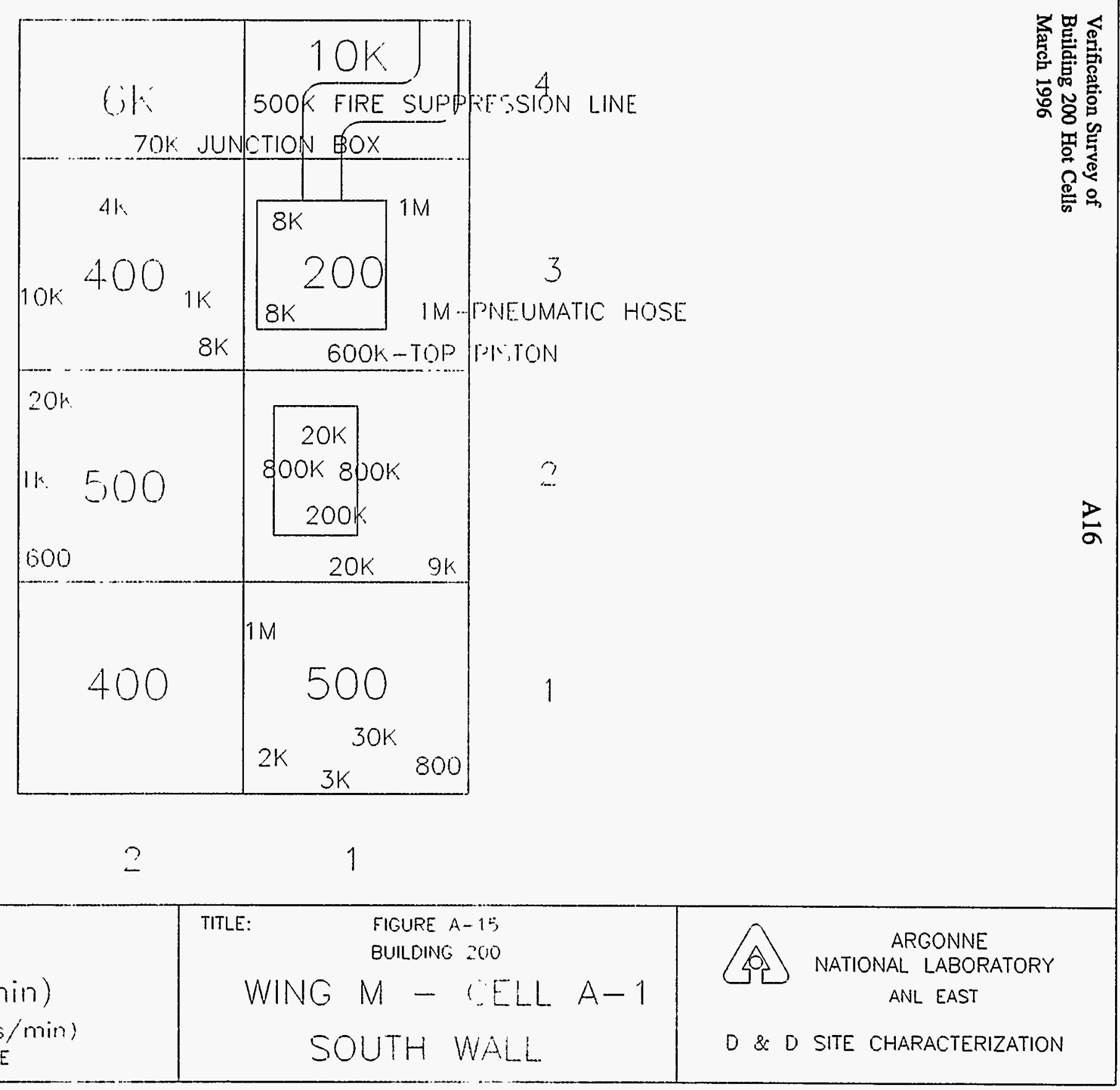




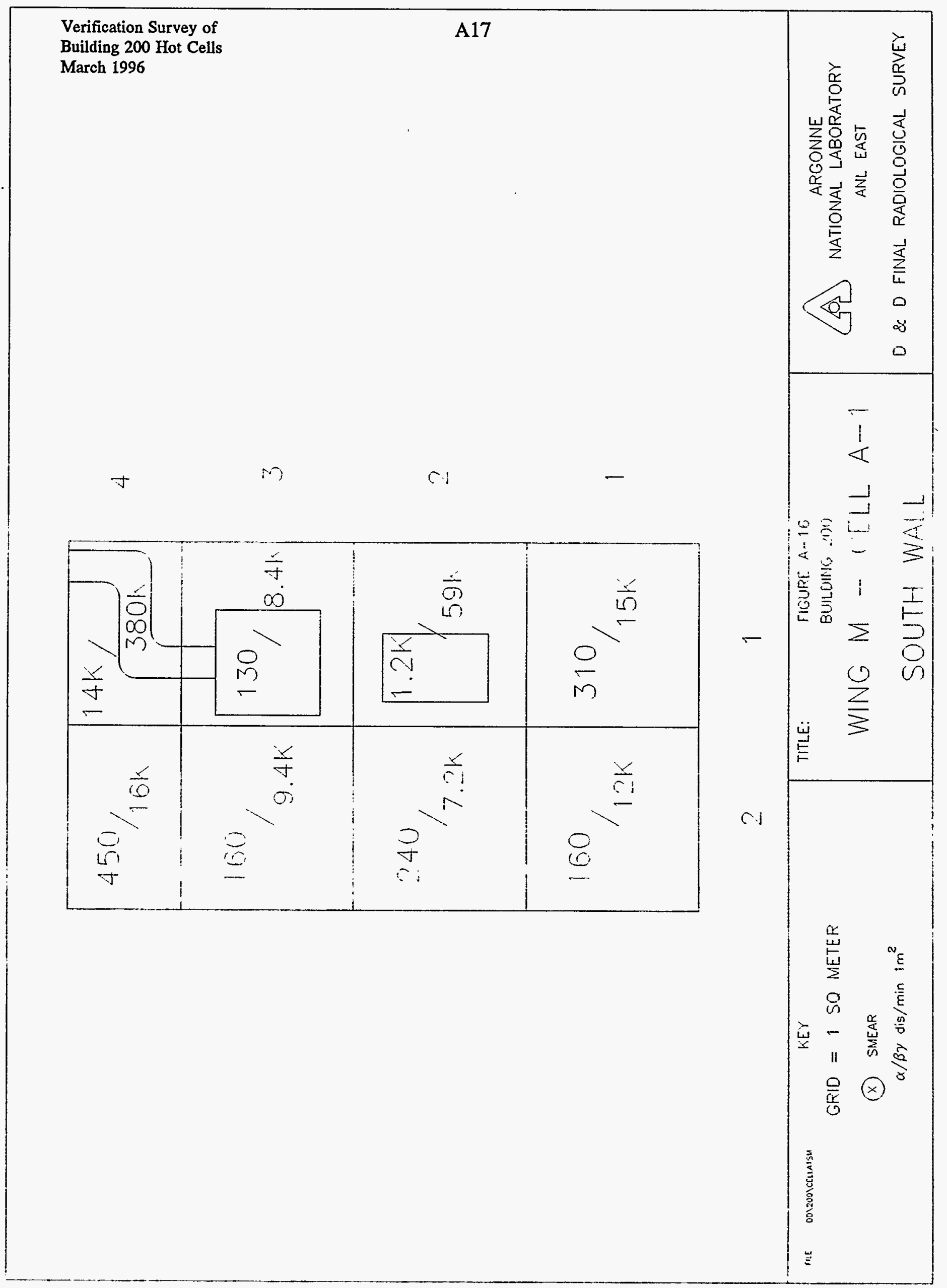


Verification Survey of

Building 200 Hot Cells

March 1996
A18

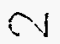

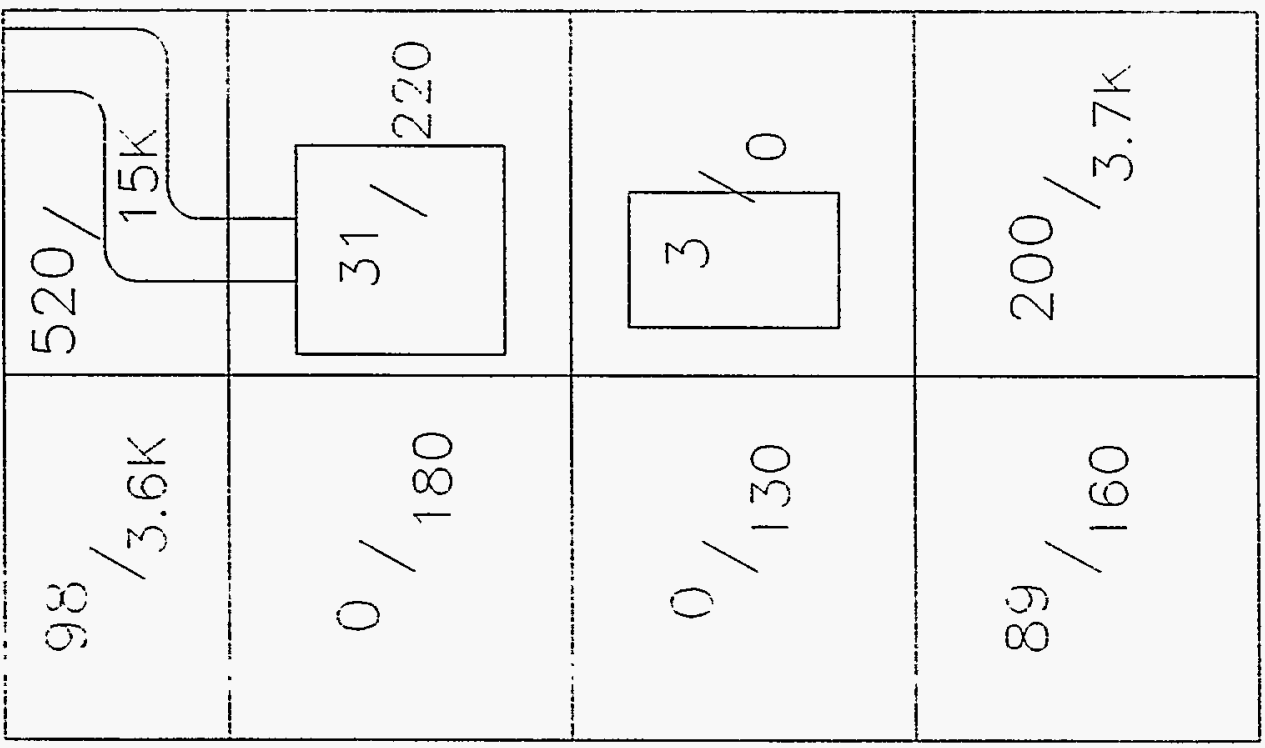

$\nabla$

$m$

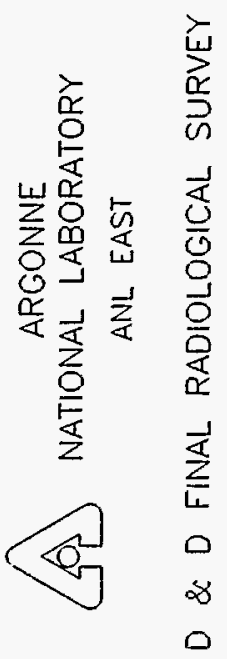

$\leftarrow$

$=8 \stackrel{-\frac{1}{4}}{\frac{1}{3}}$

㟧

㟧言 1 I

产 $\sum \stackrel{\bar{\Xi}}{\bar{\Xi}}$

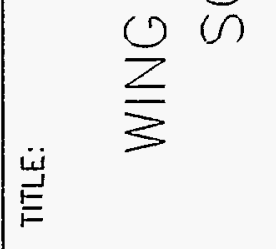

$c 1$

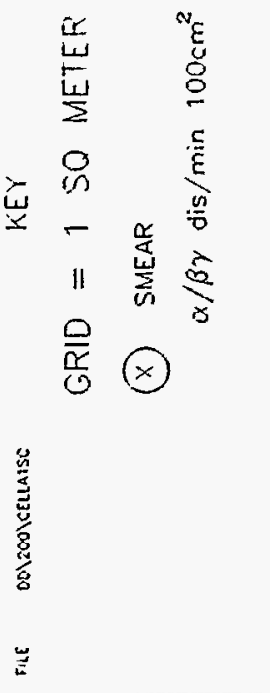




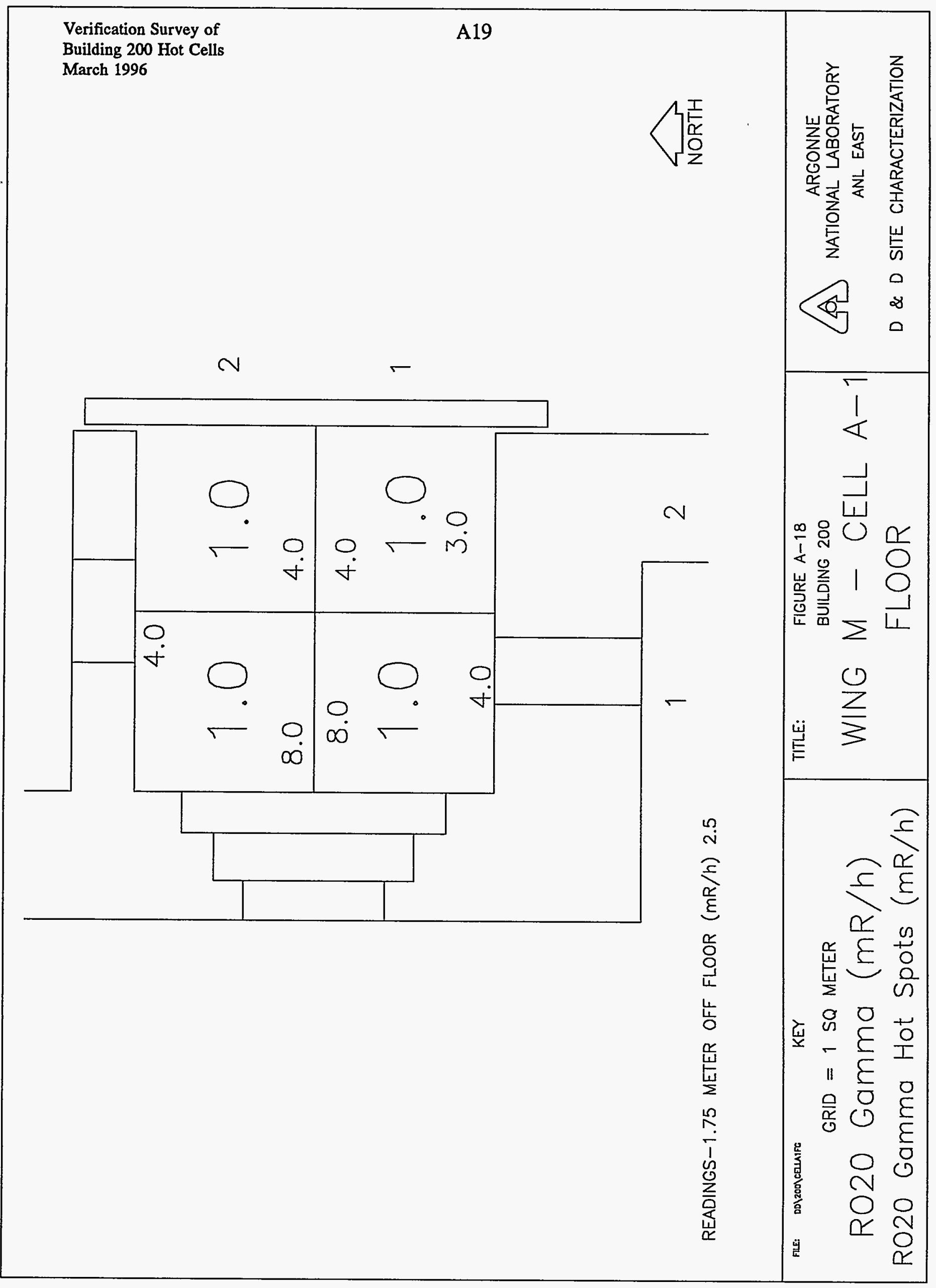




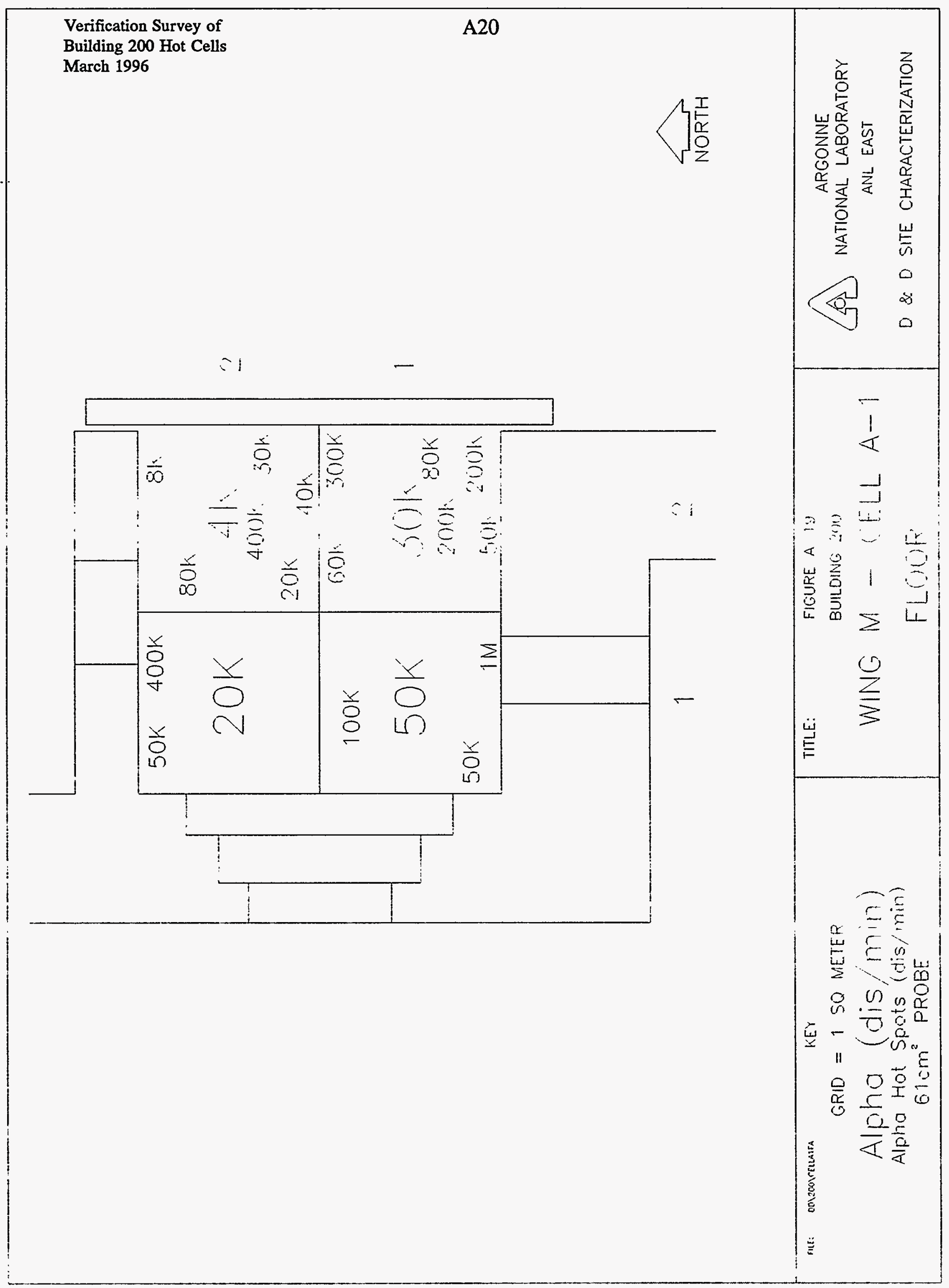




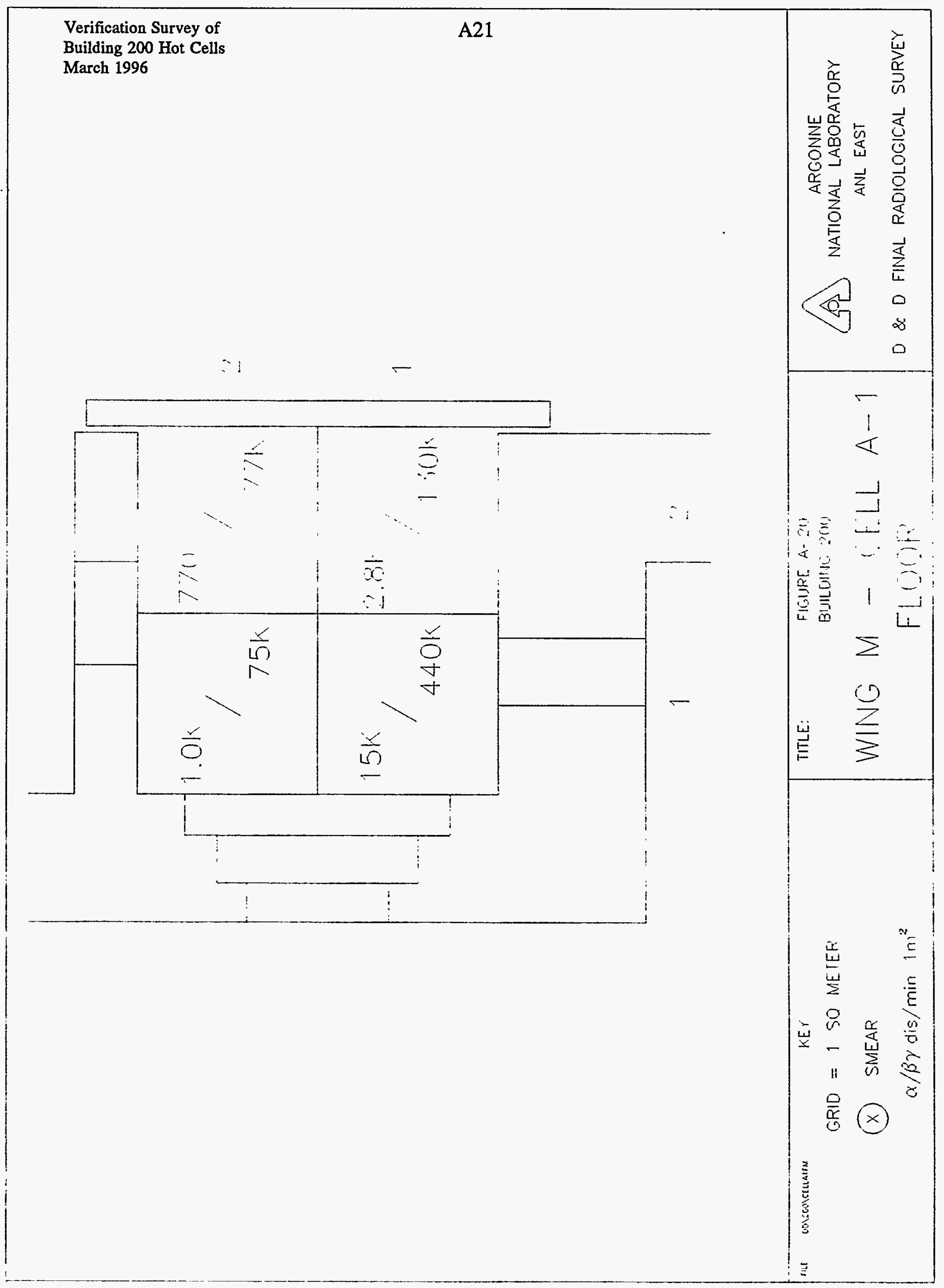




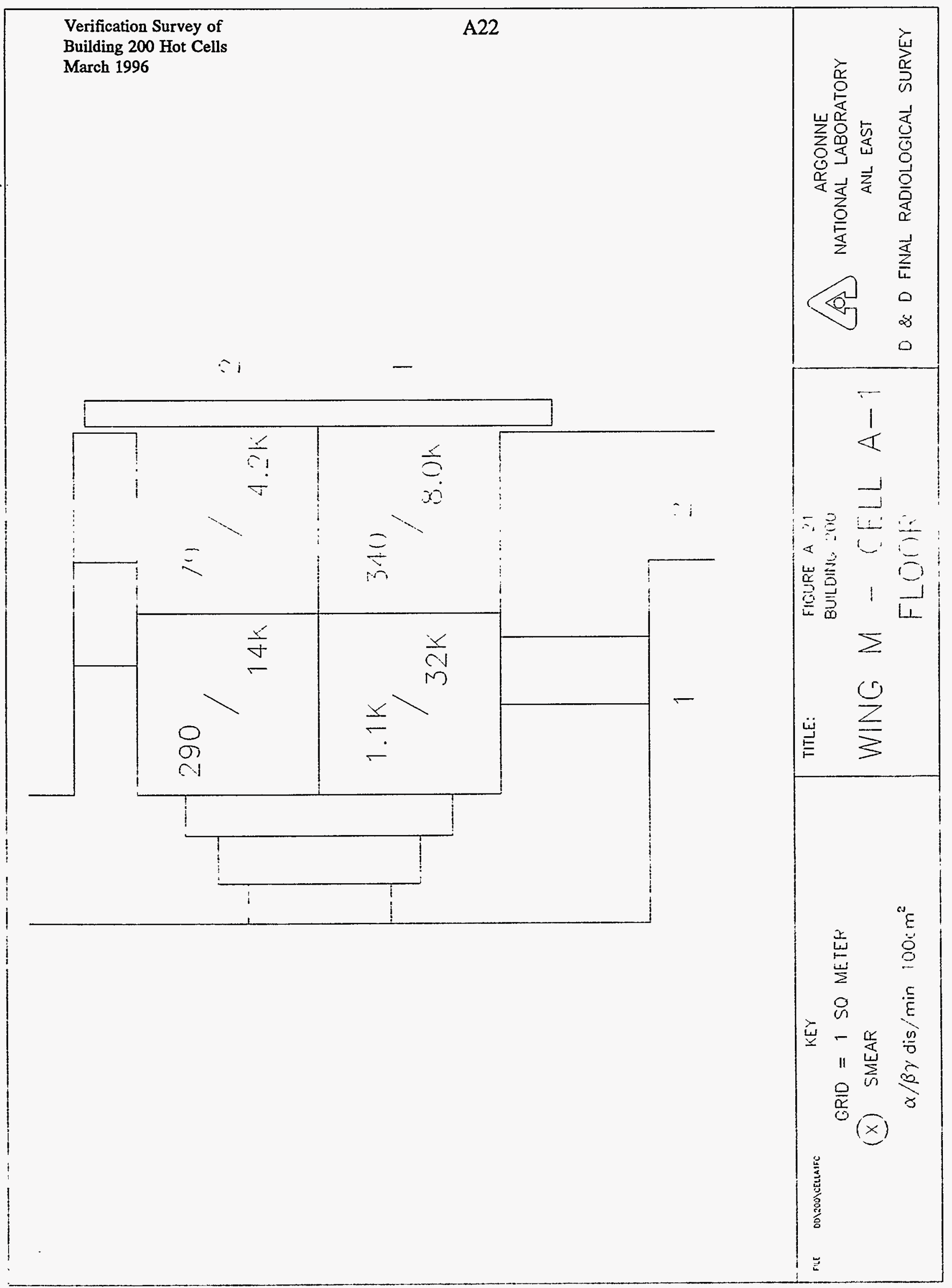




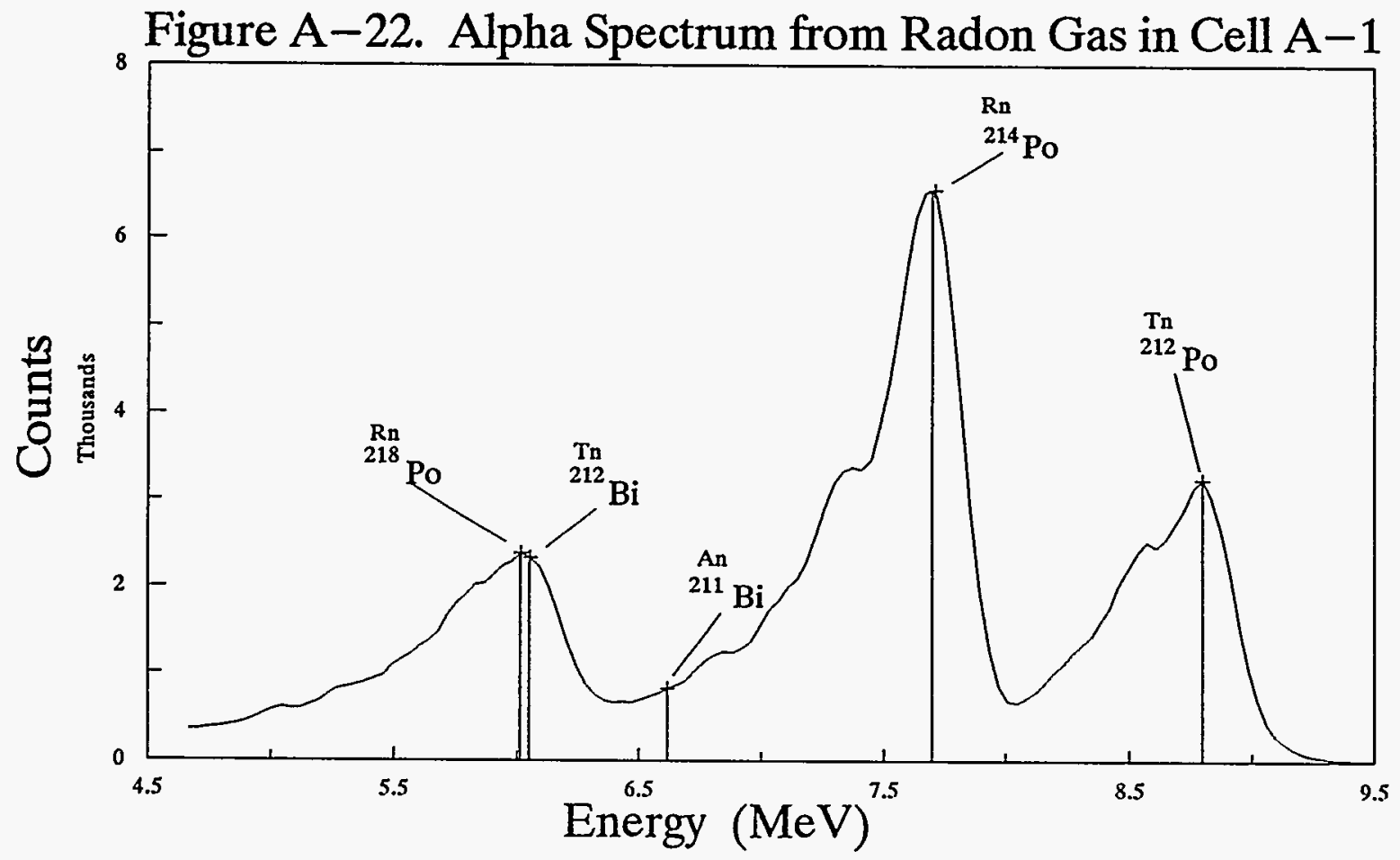

Figure A-23. Alpha-6 Rn \& Tn Activities in Cell A-1

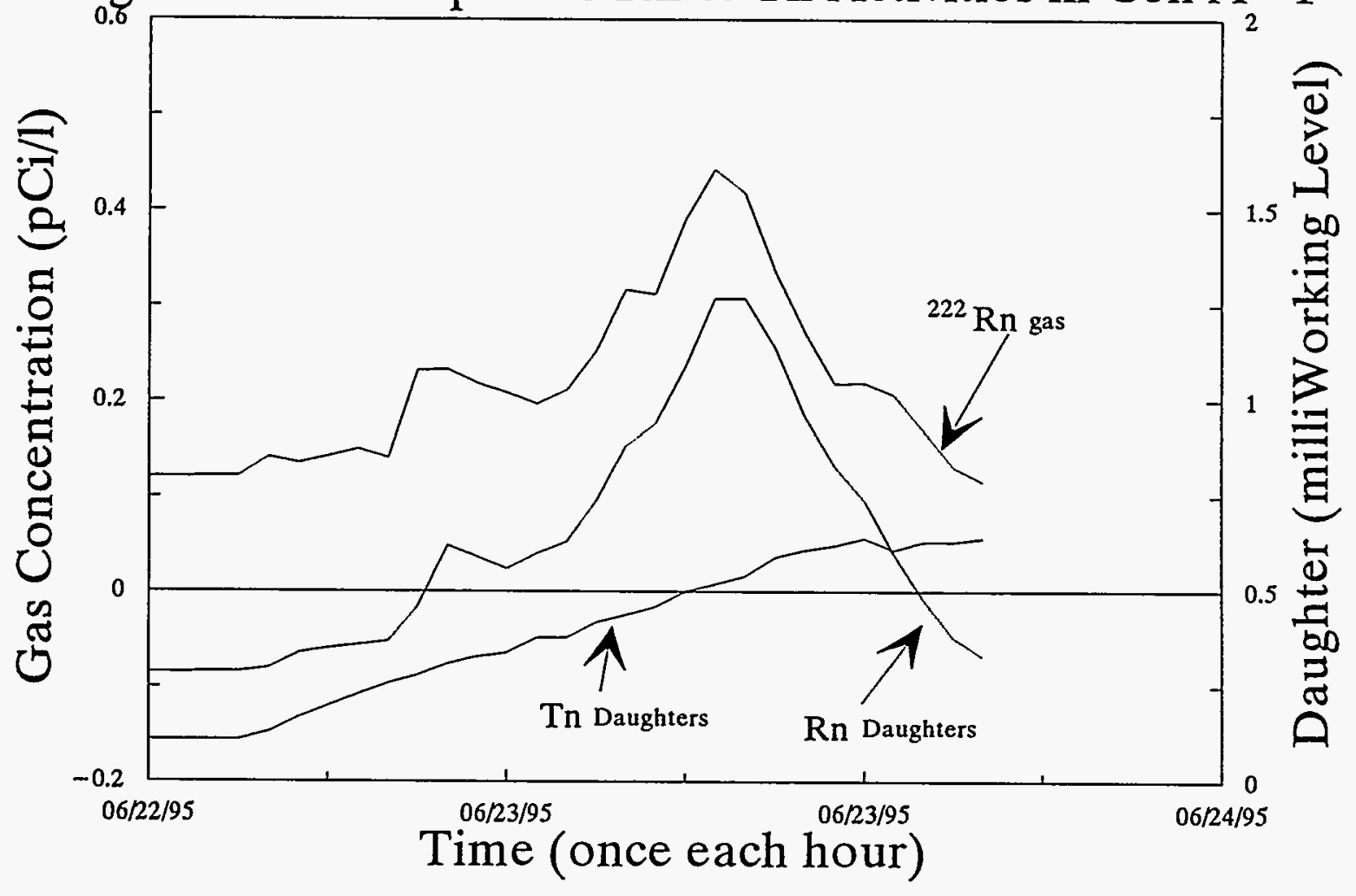


Verification Survey of Building 200 Hot Cells March 1996
A24

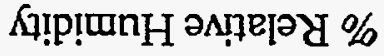

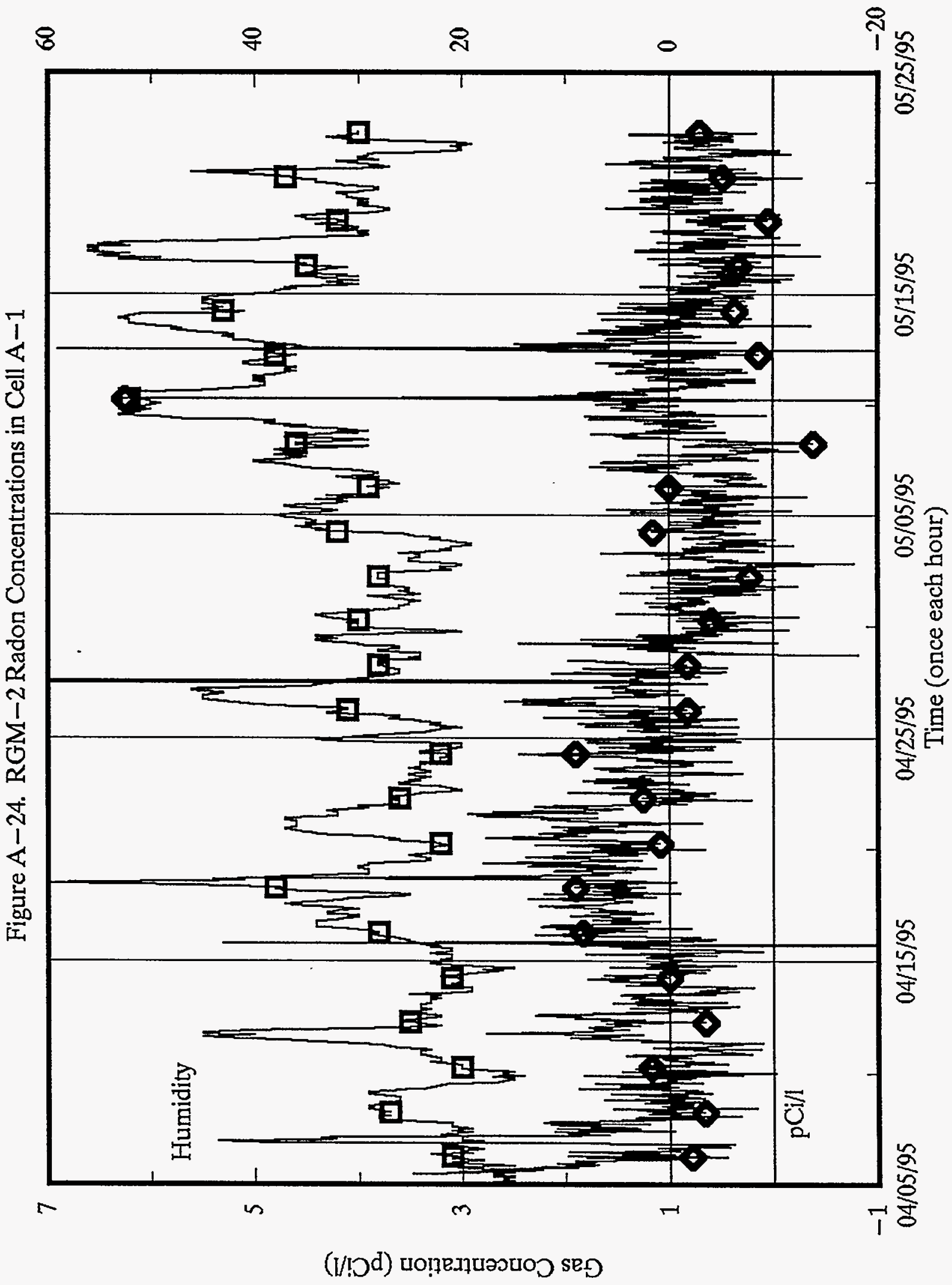


Verification Survey of Building 200 Hot Cells

March 1996
B1

APPENDIX B Cell K-1 Figures 


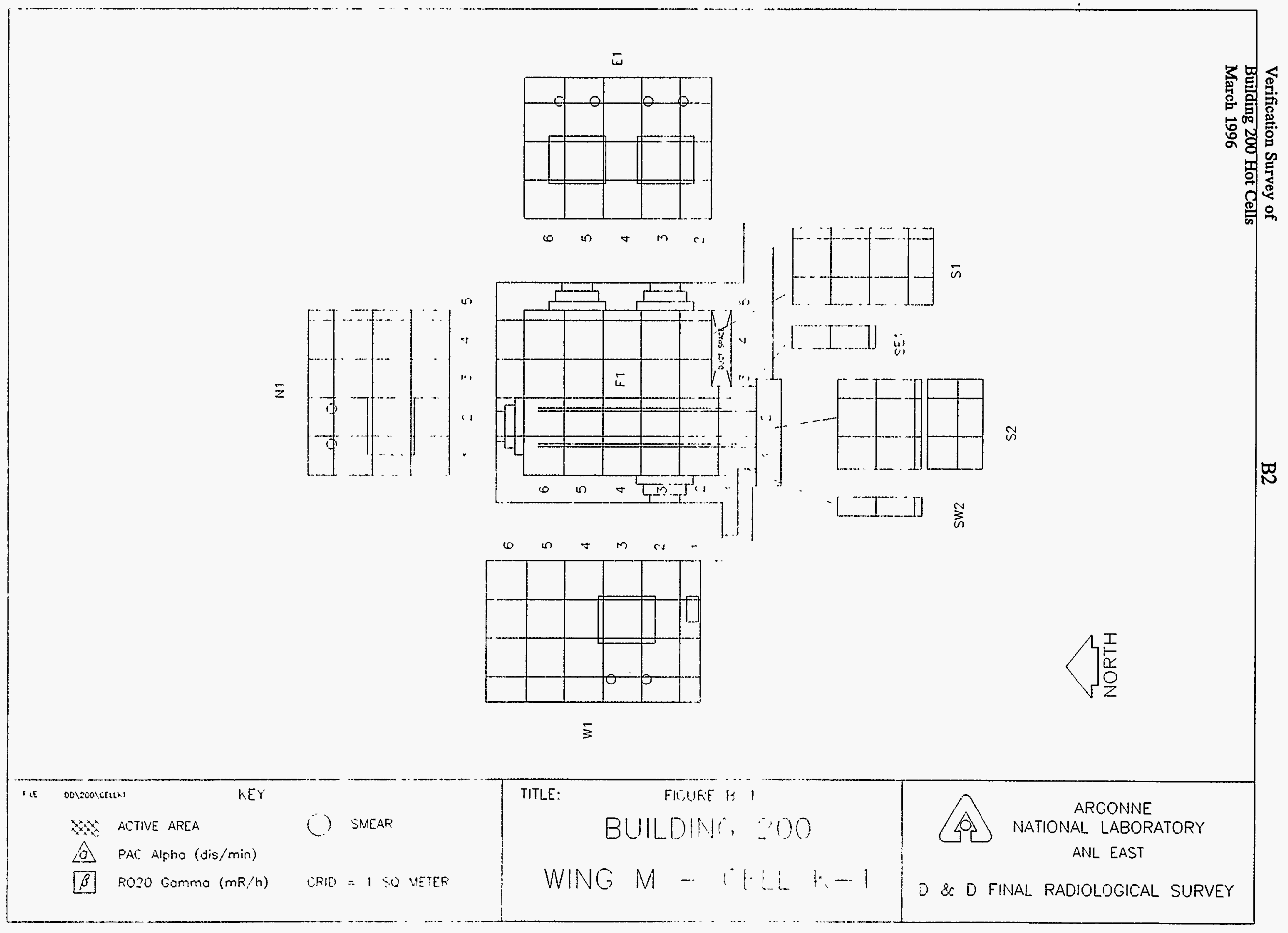




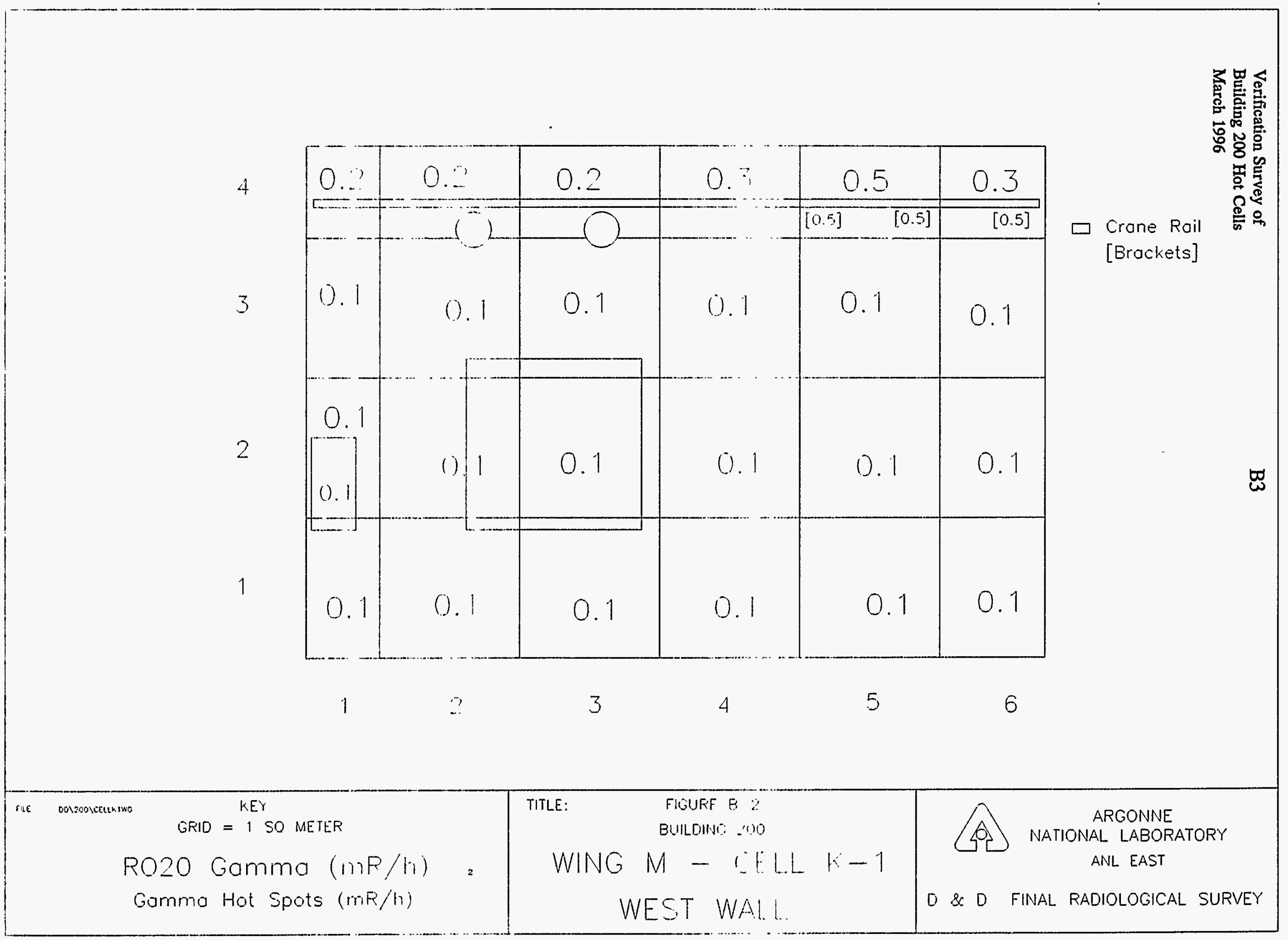




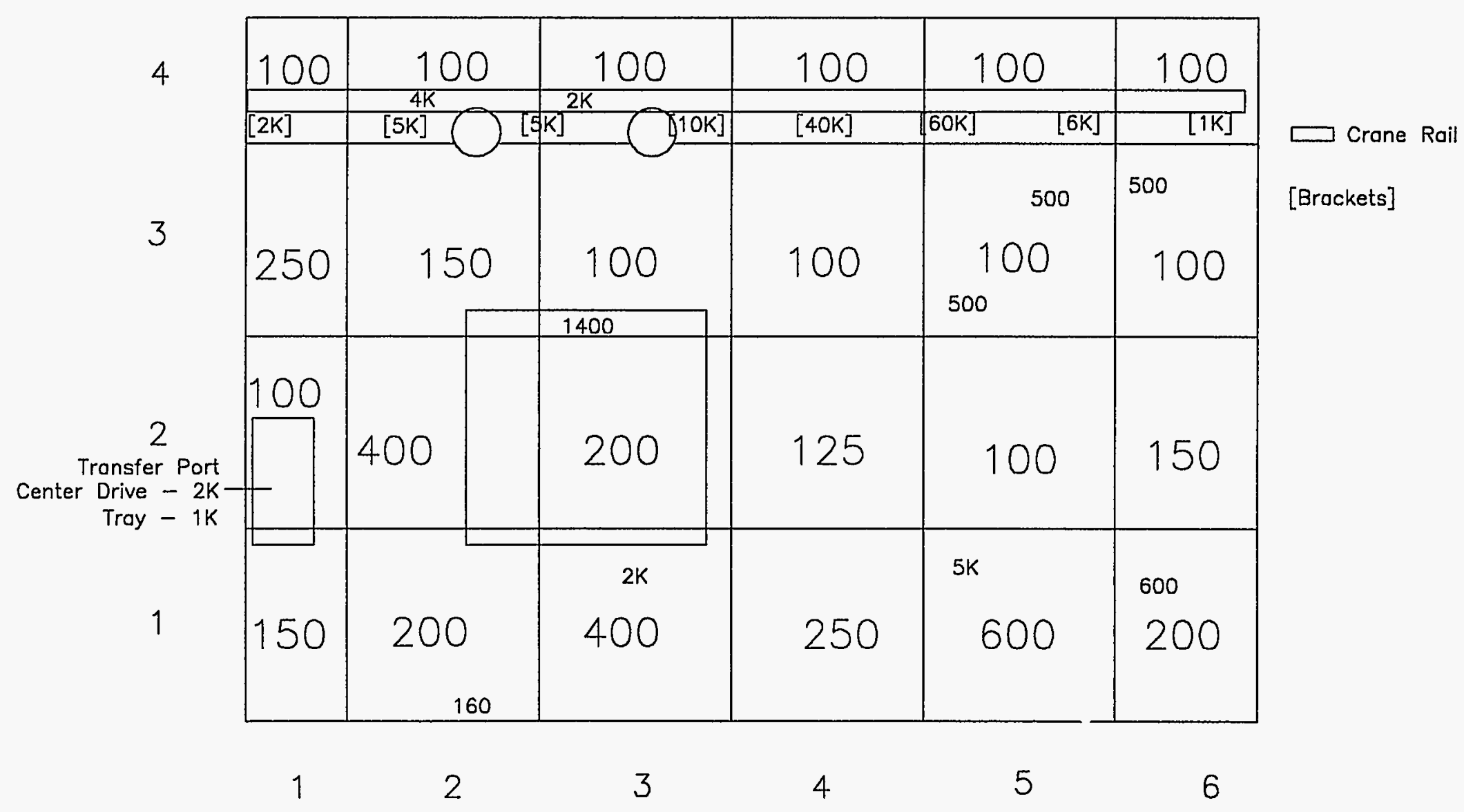

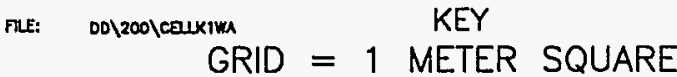

PAC Alpha (dis/min)

Alpha Hot Spots (dis/min)

ALL READINGS $-61 \mathrm{~cm}^{2}$ PROBE
TITLE: FIGURE B-3

BUILDING 200

WING $M$ - CELL K-1

WEST WALL
ARGONNE

NATIONAL LABORATORY

ANL EAST

ARGONNE
NATIONAL LABORATORY
ANL EAST
\& D FINAL RADIOLOGICAL SURVEY




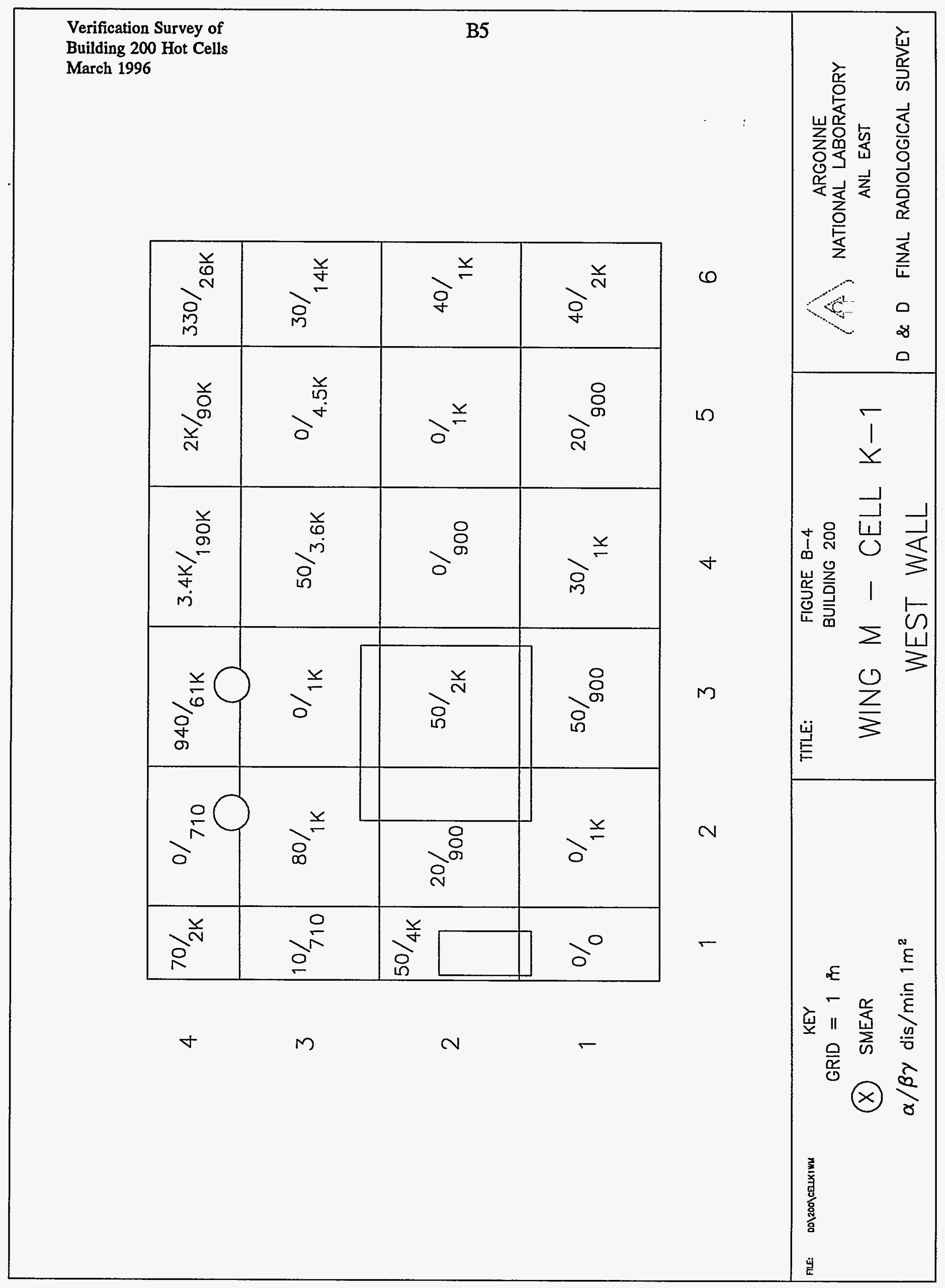




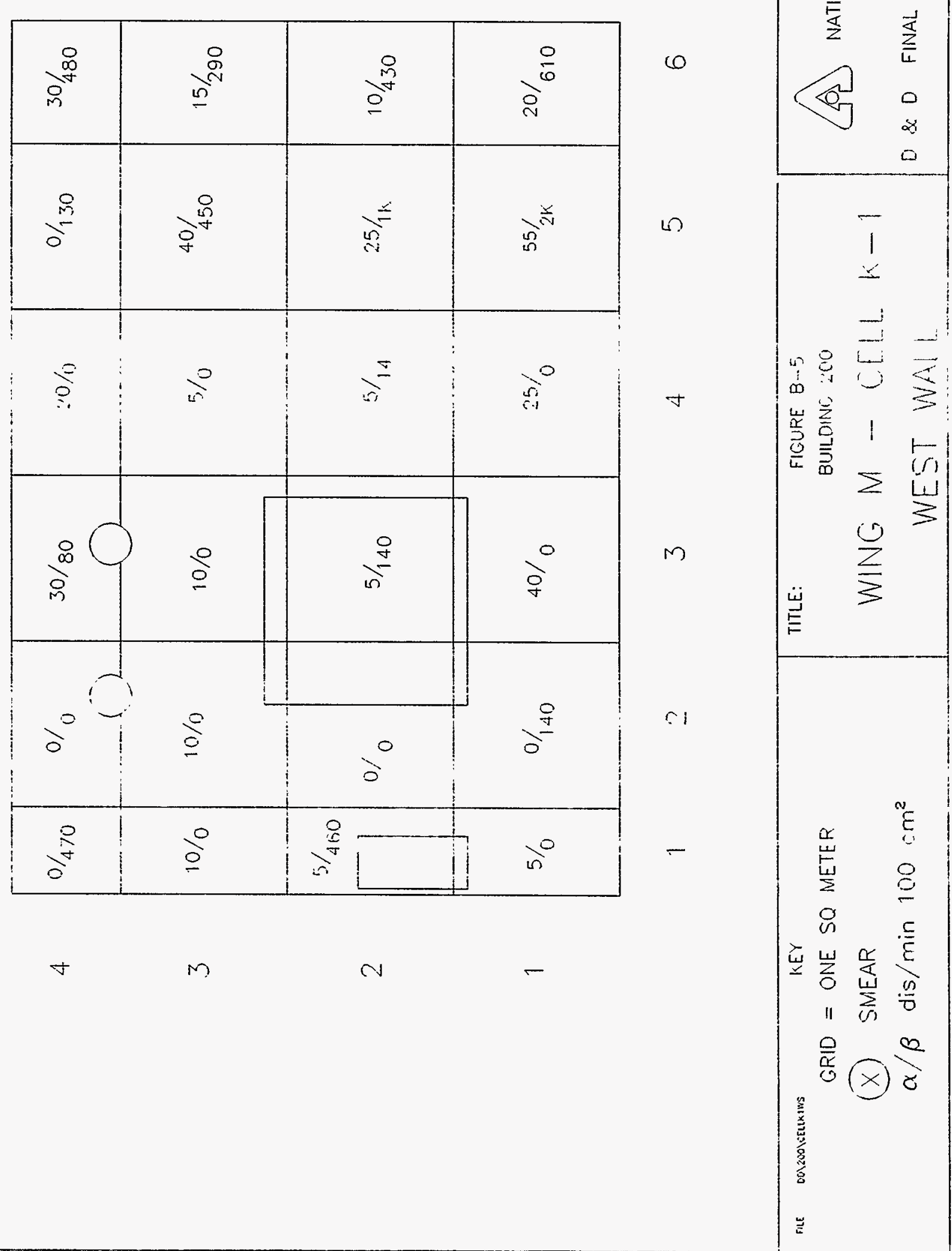




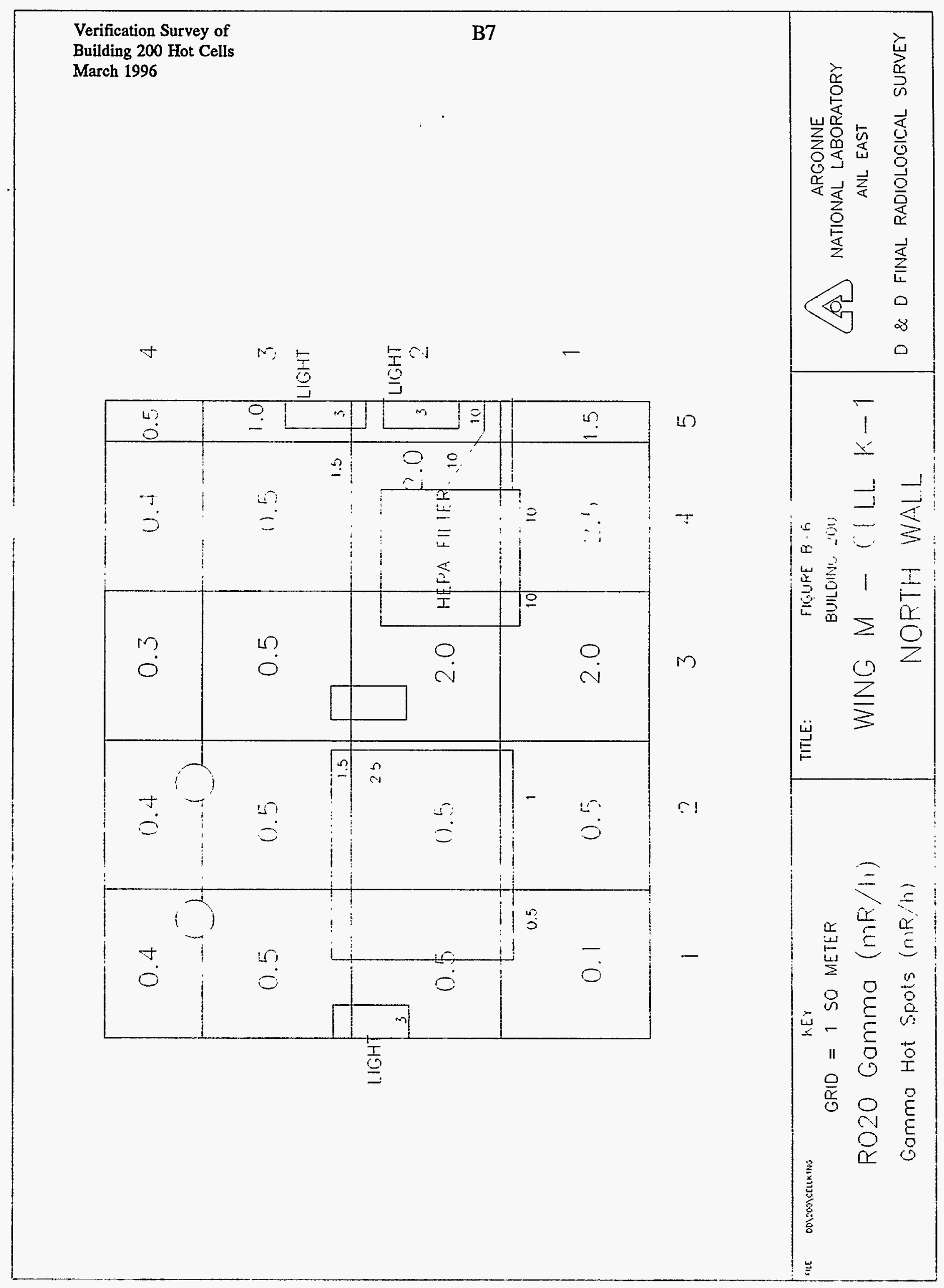




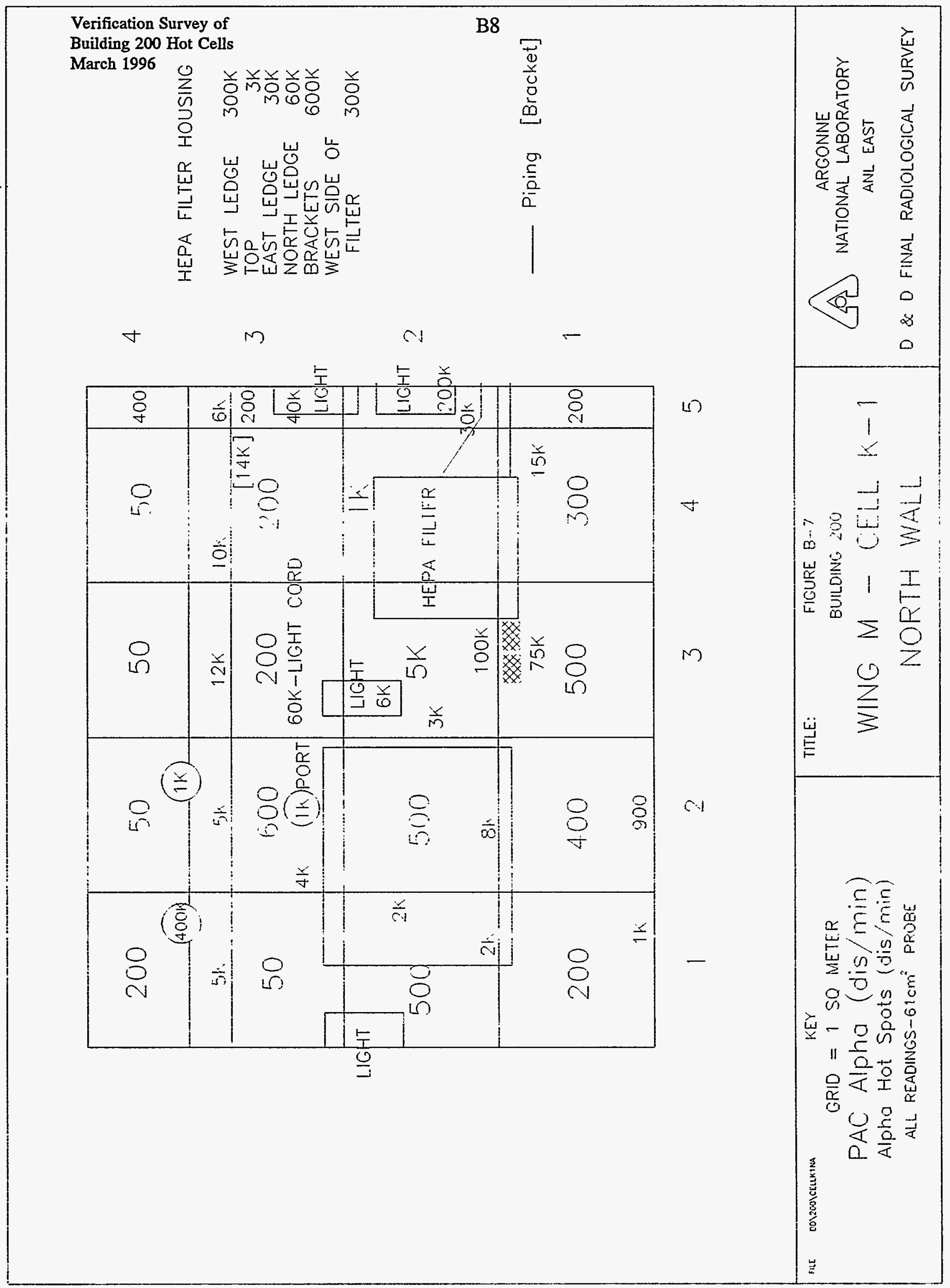



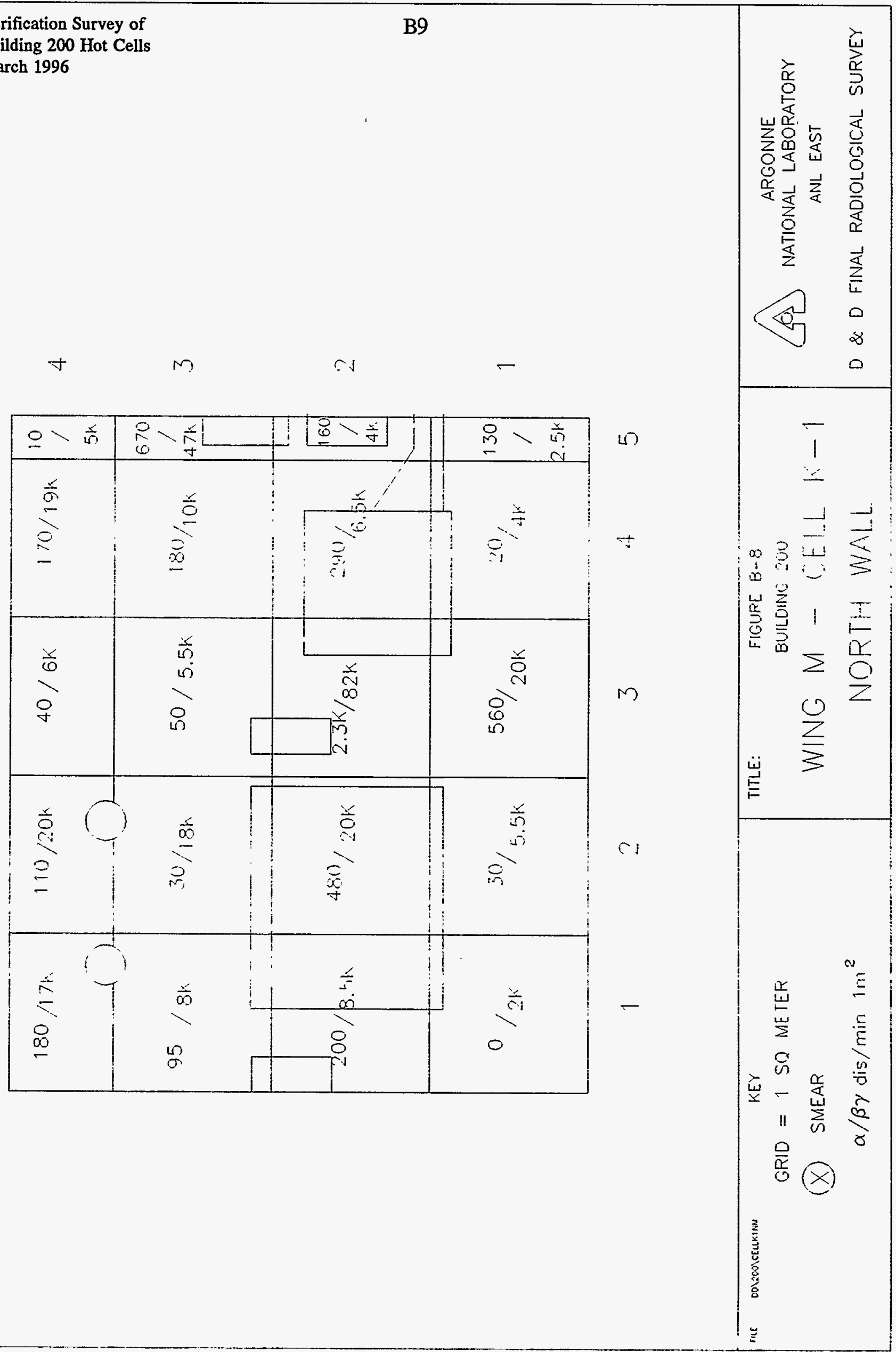


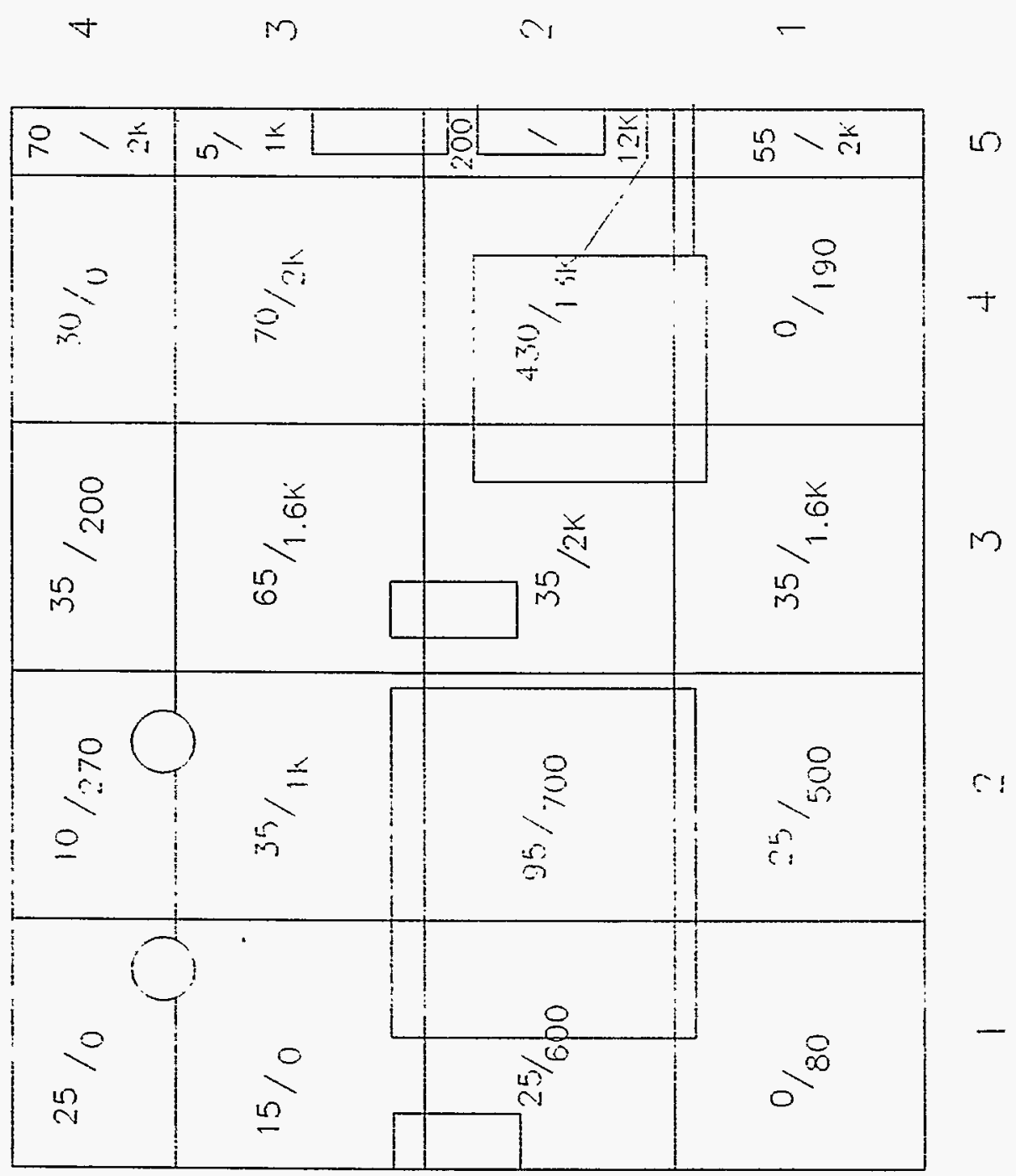




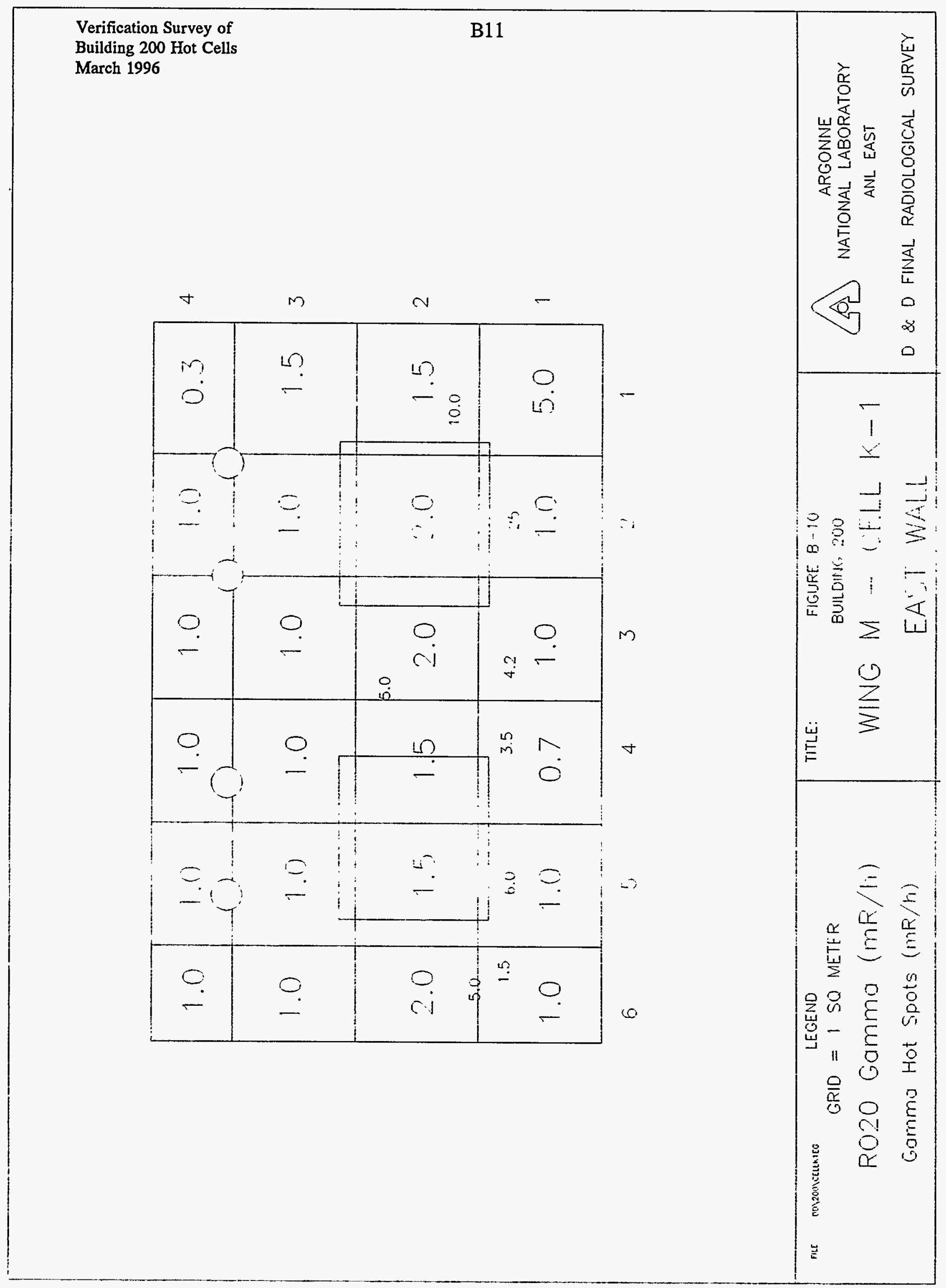



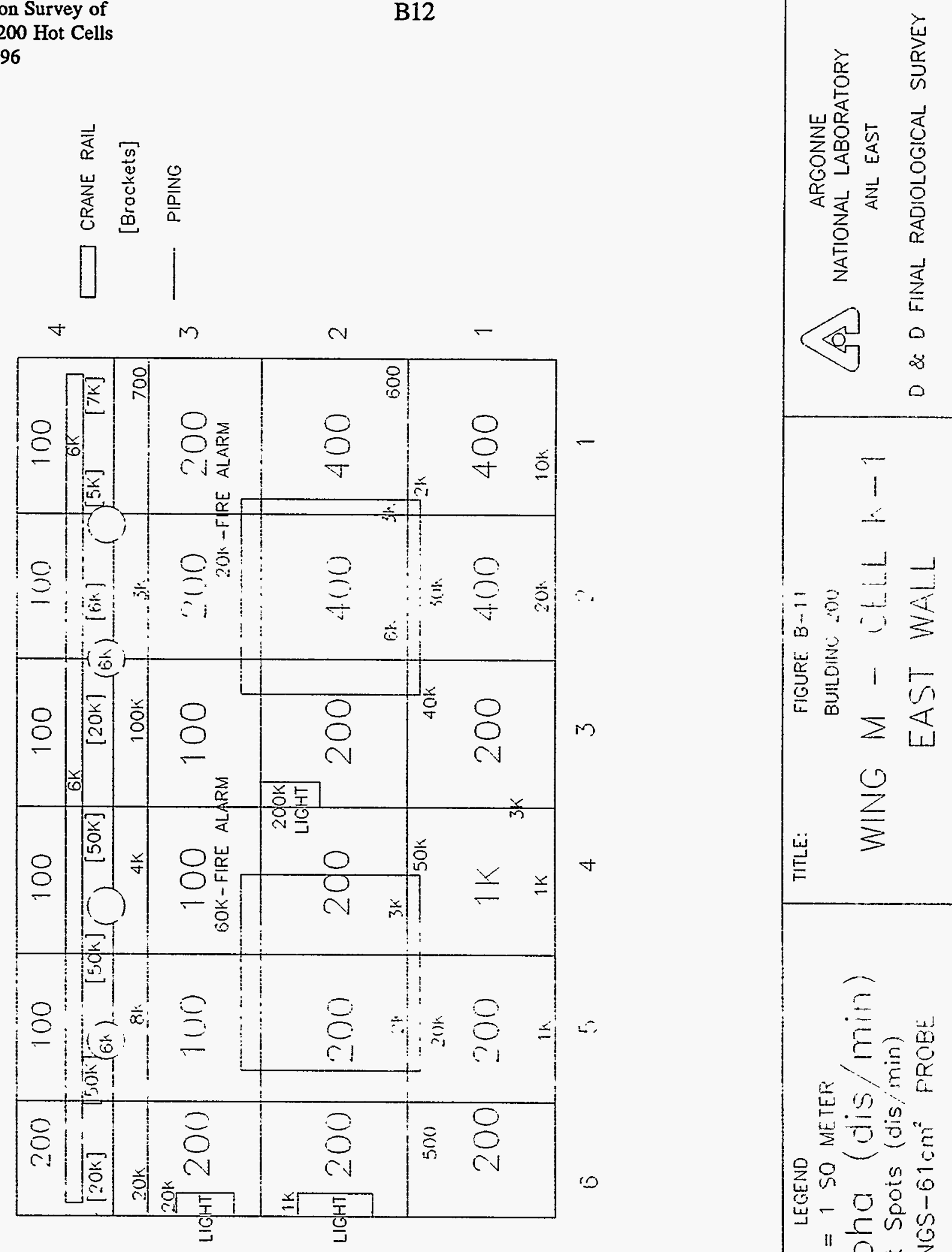


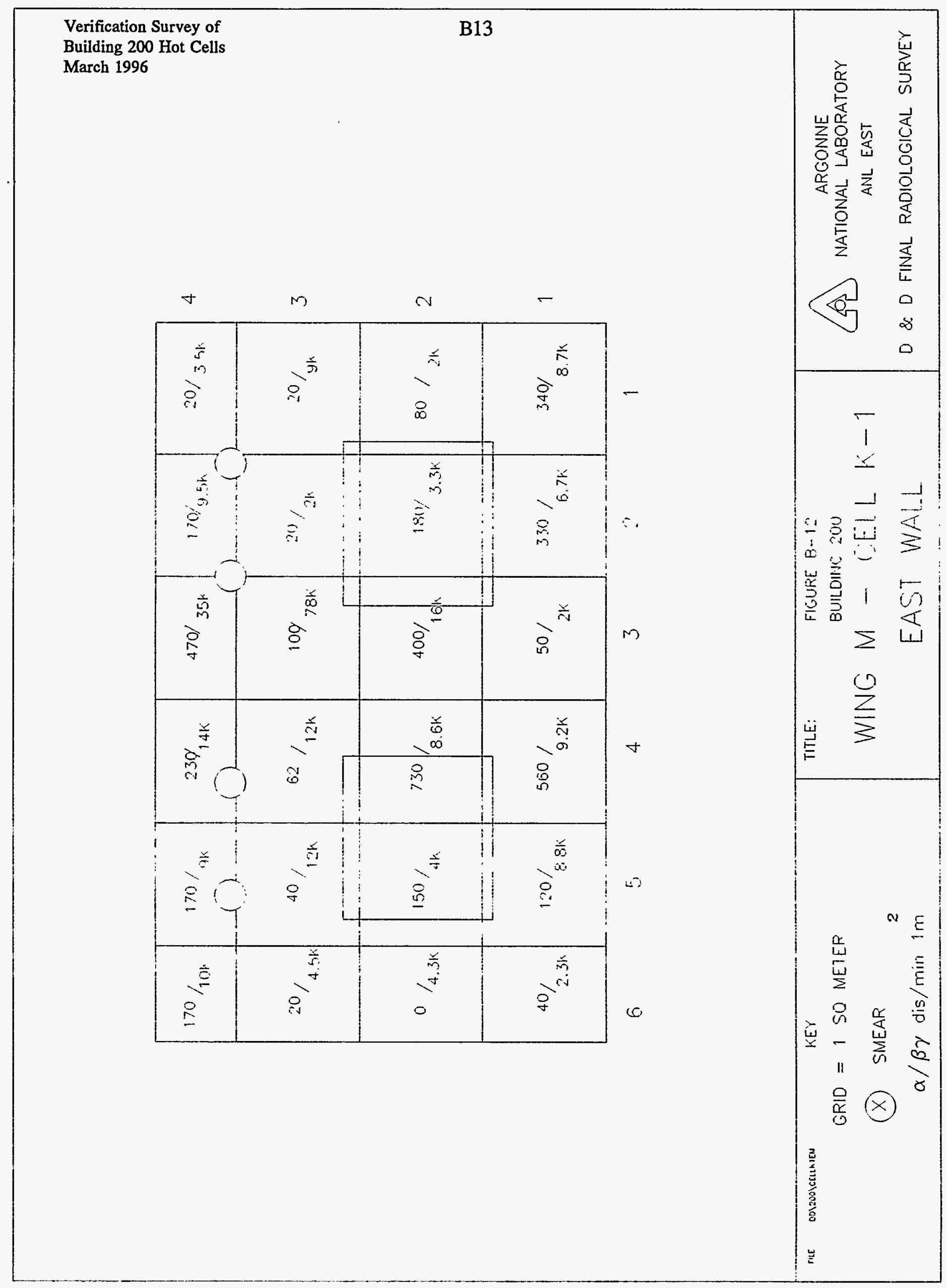




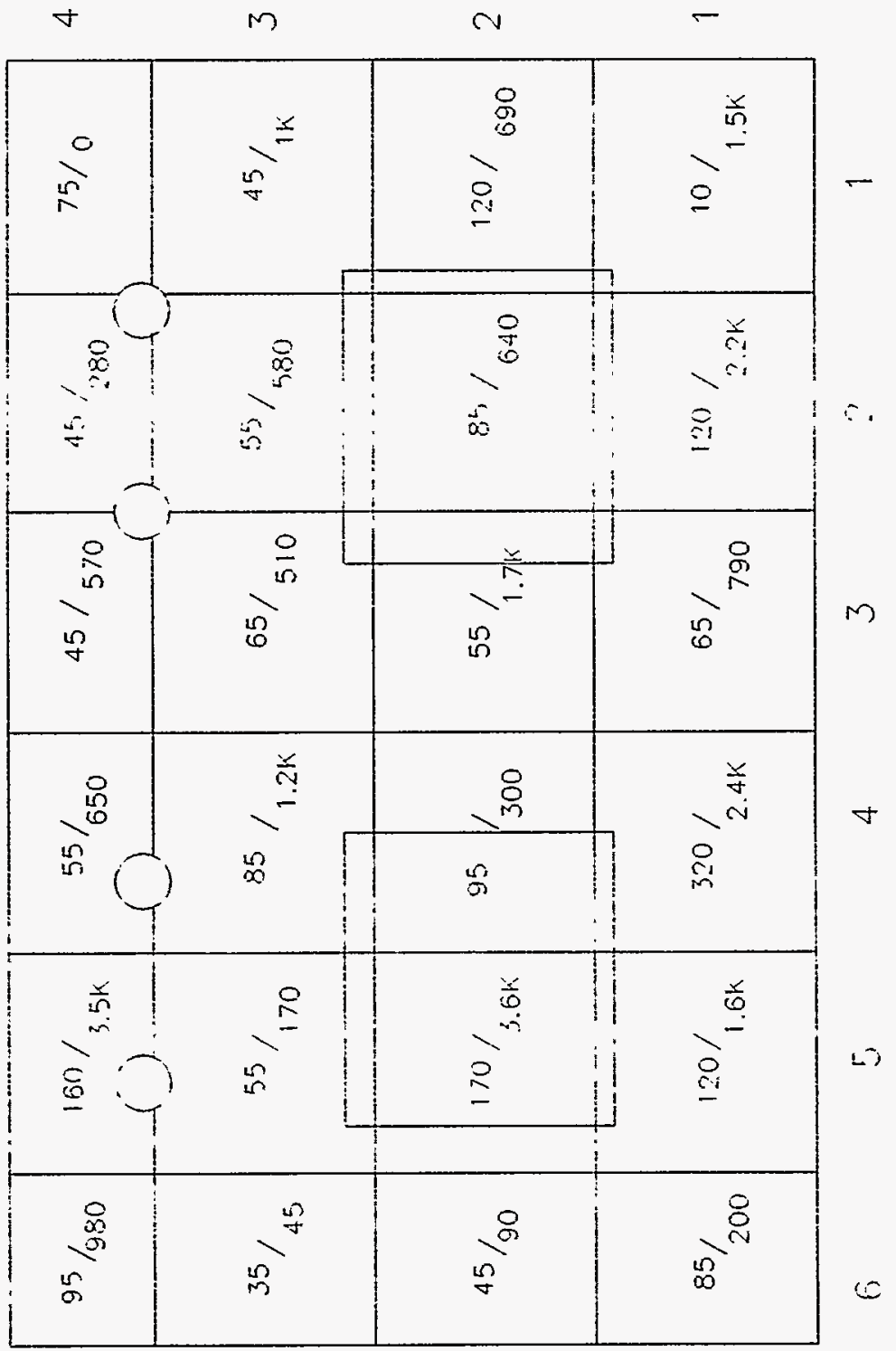


Verification Survey of

Building 200 Hot Cells

March 1996
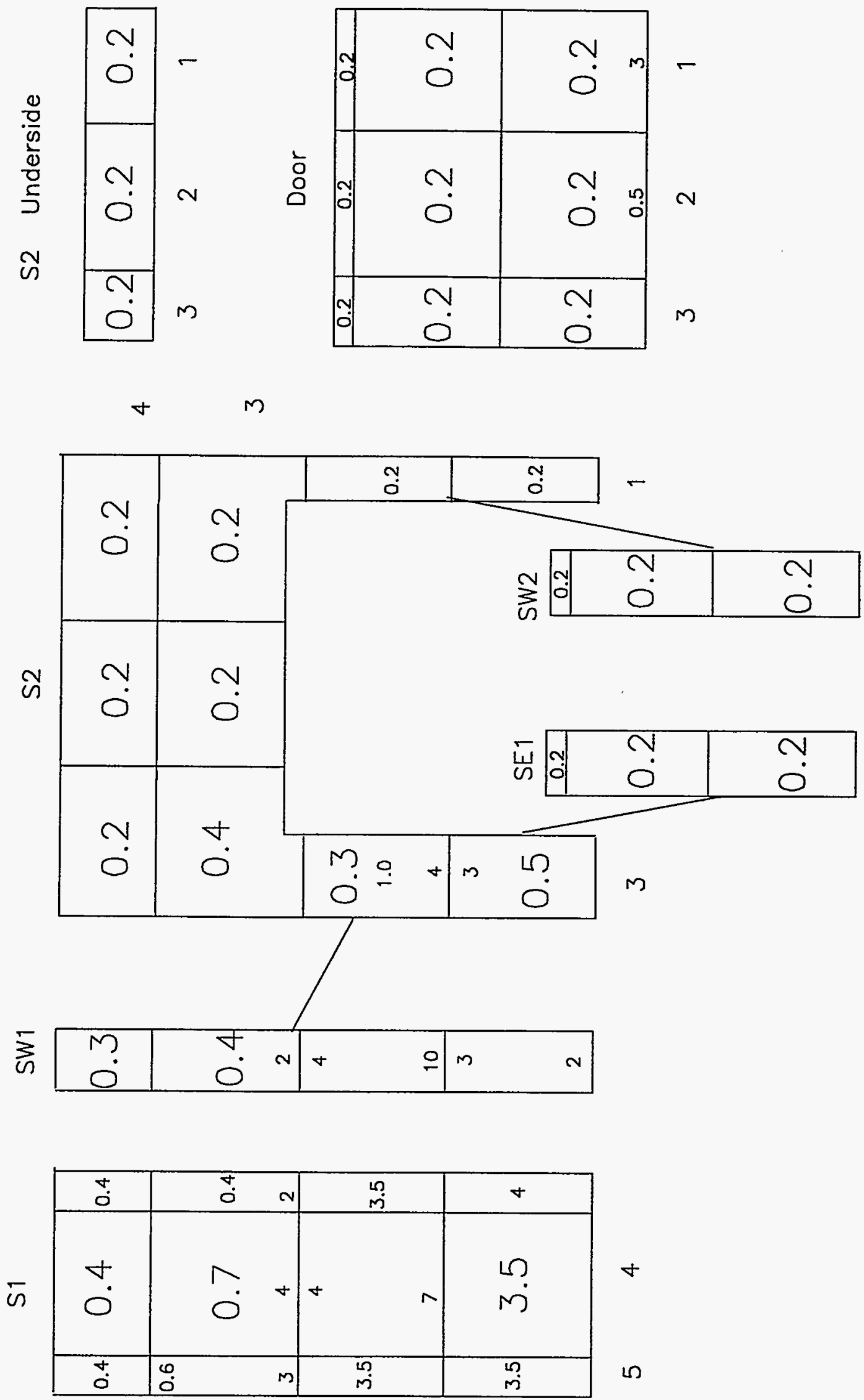
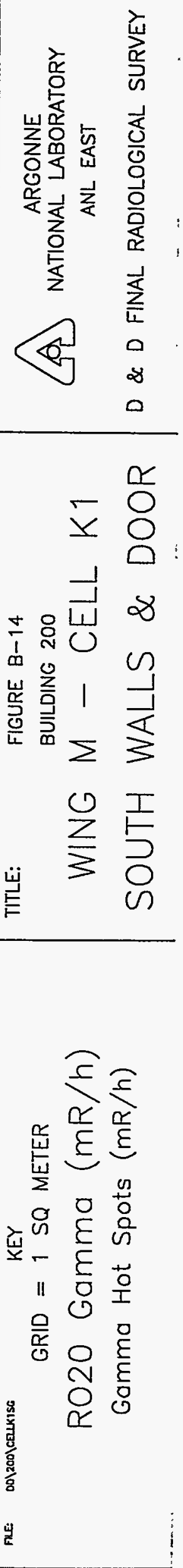


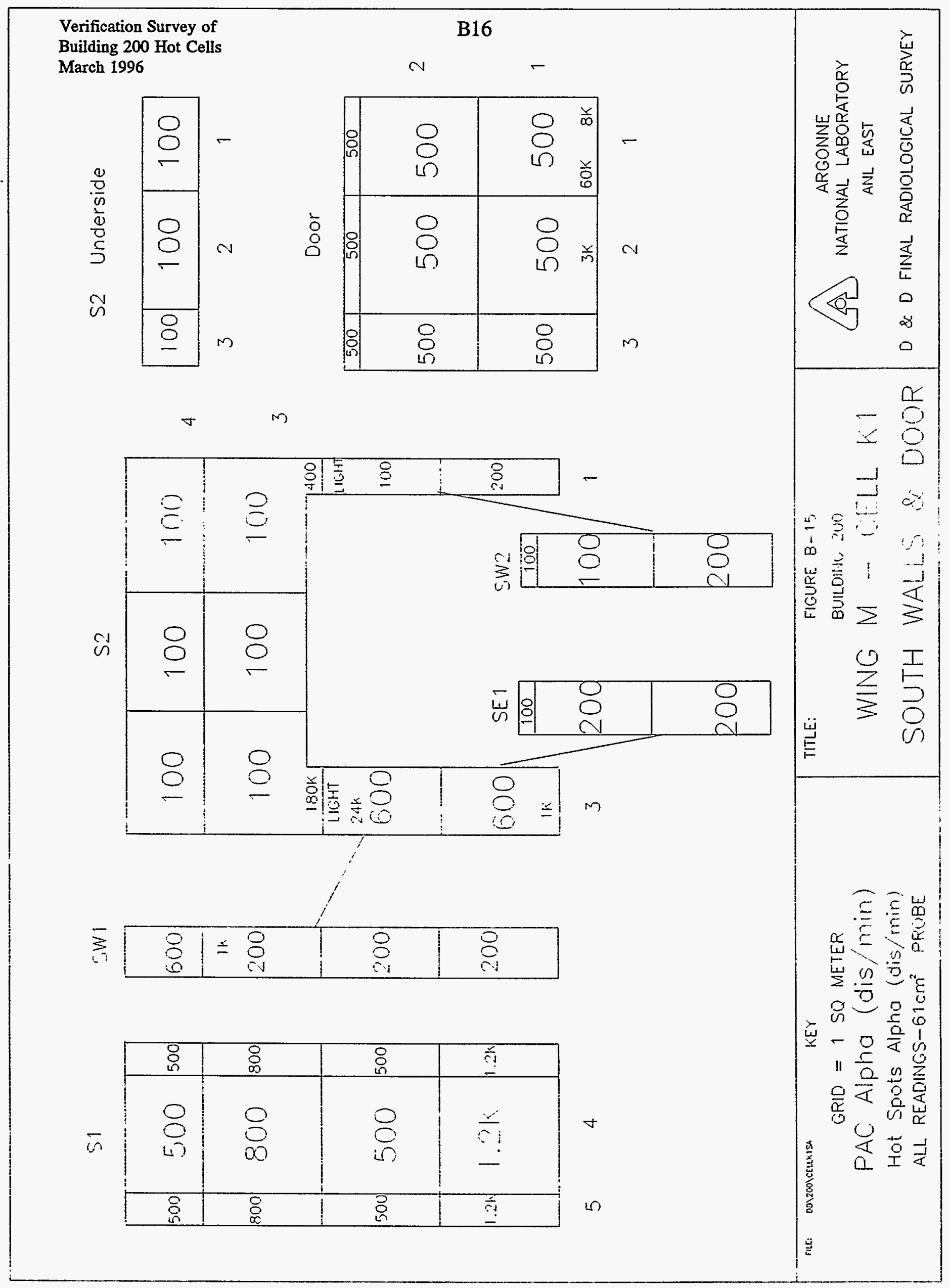




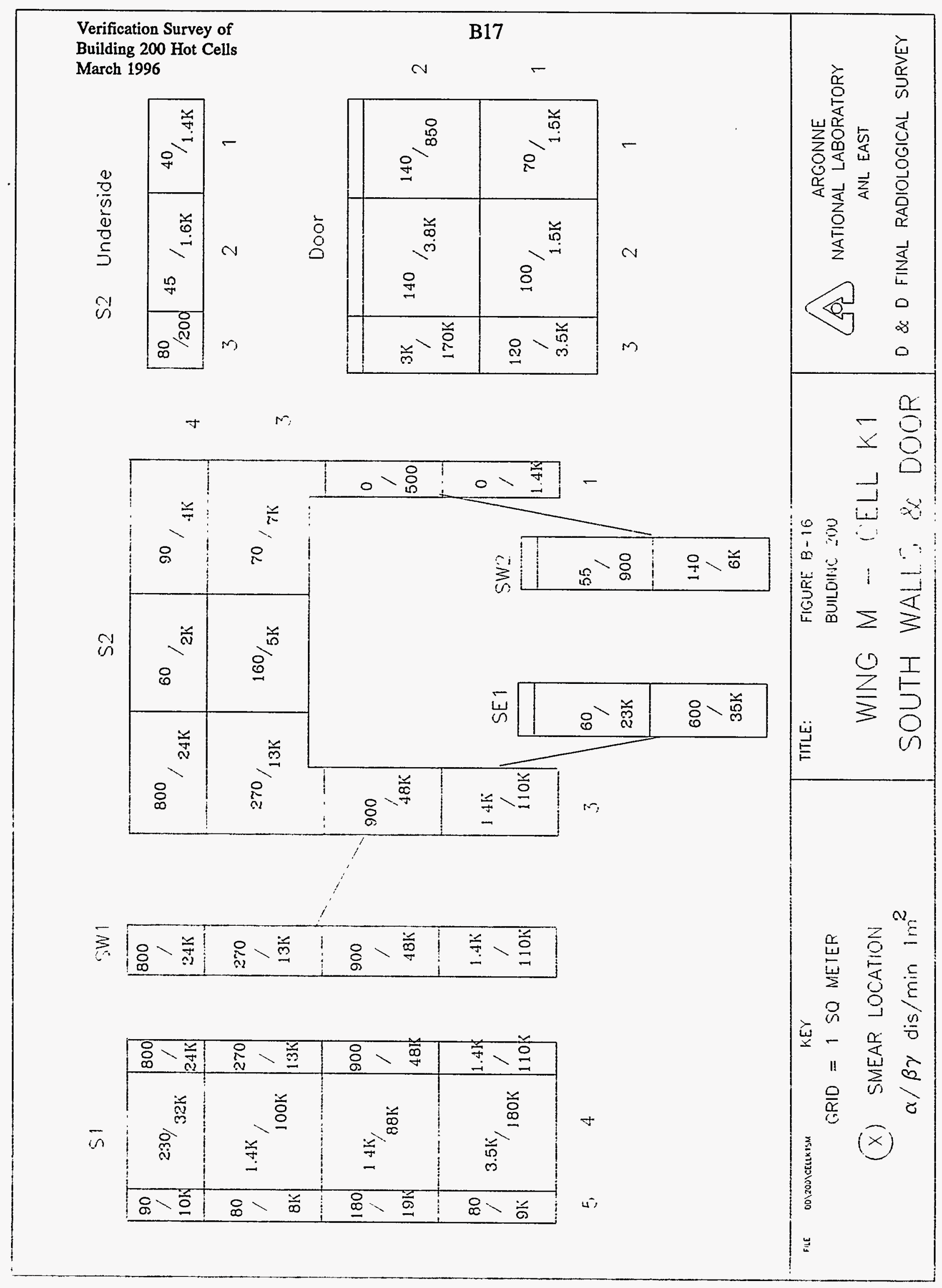


Verification Survey of Building 200 Hot Cells

March 1996
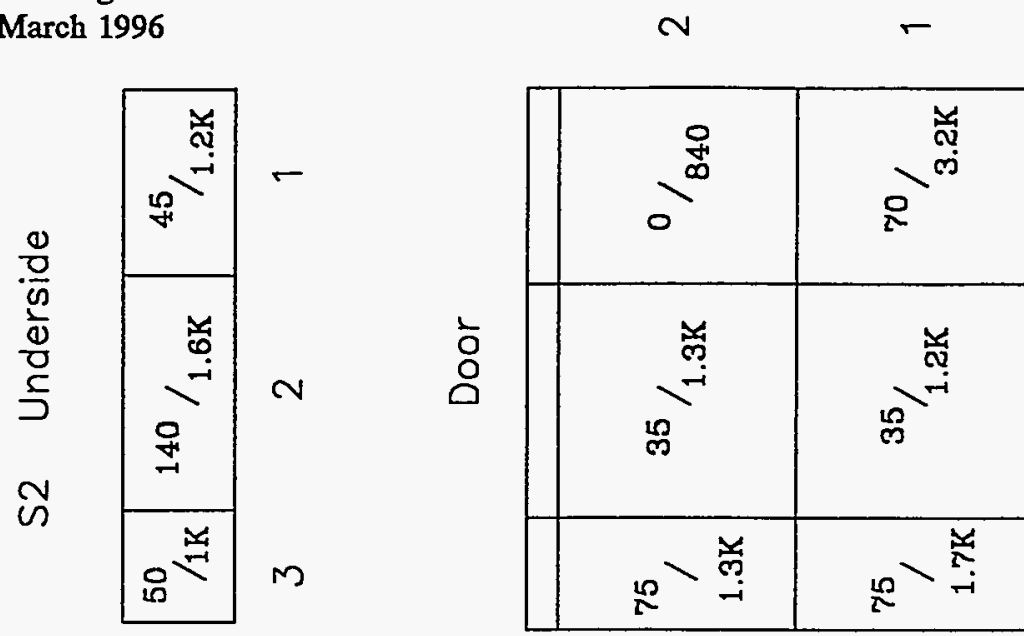

B18

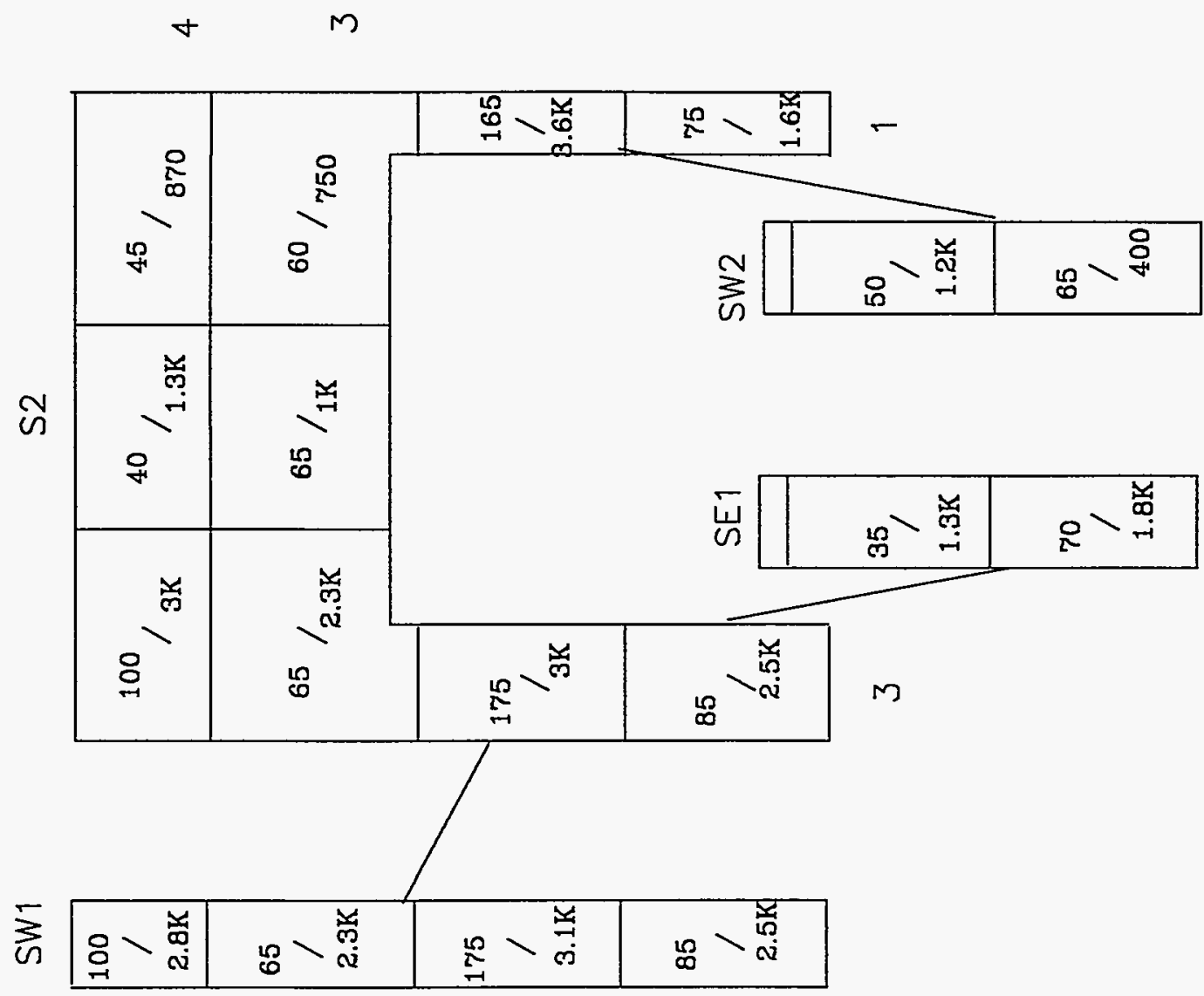

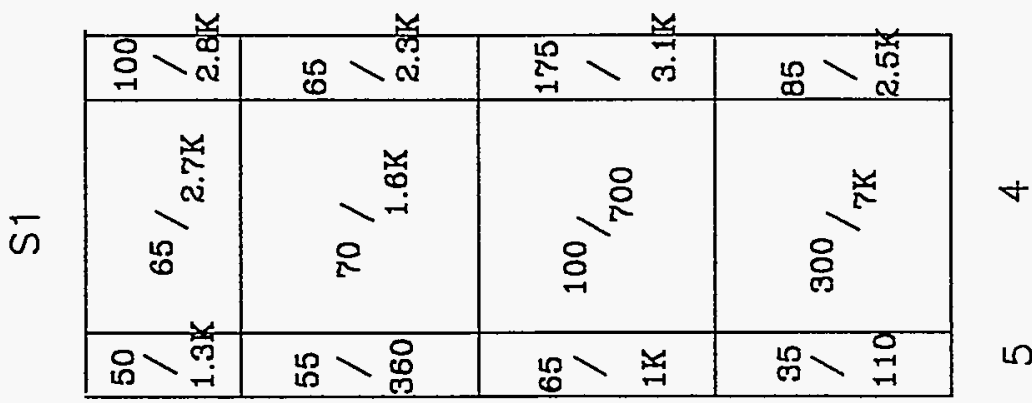
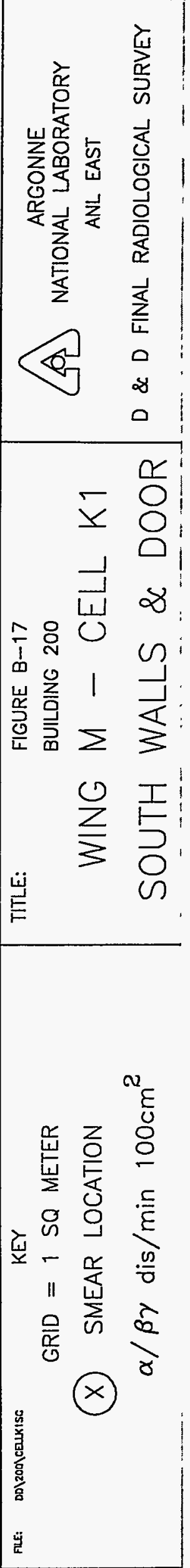


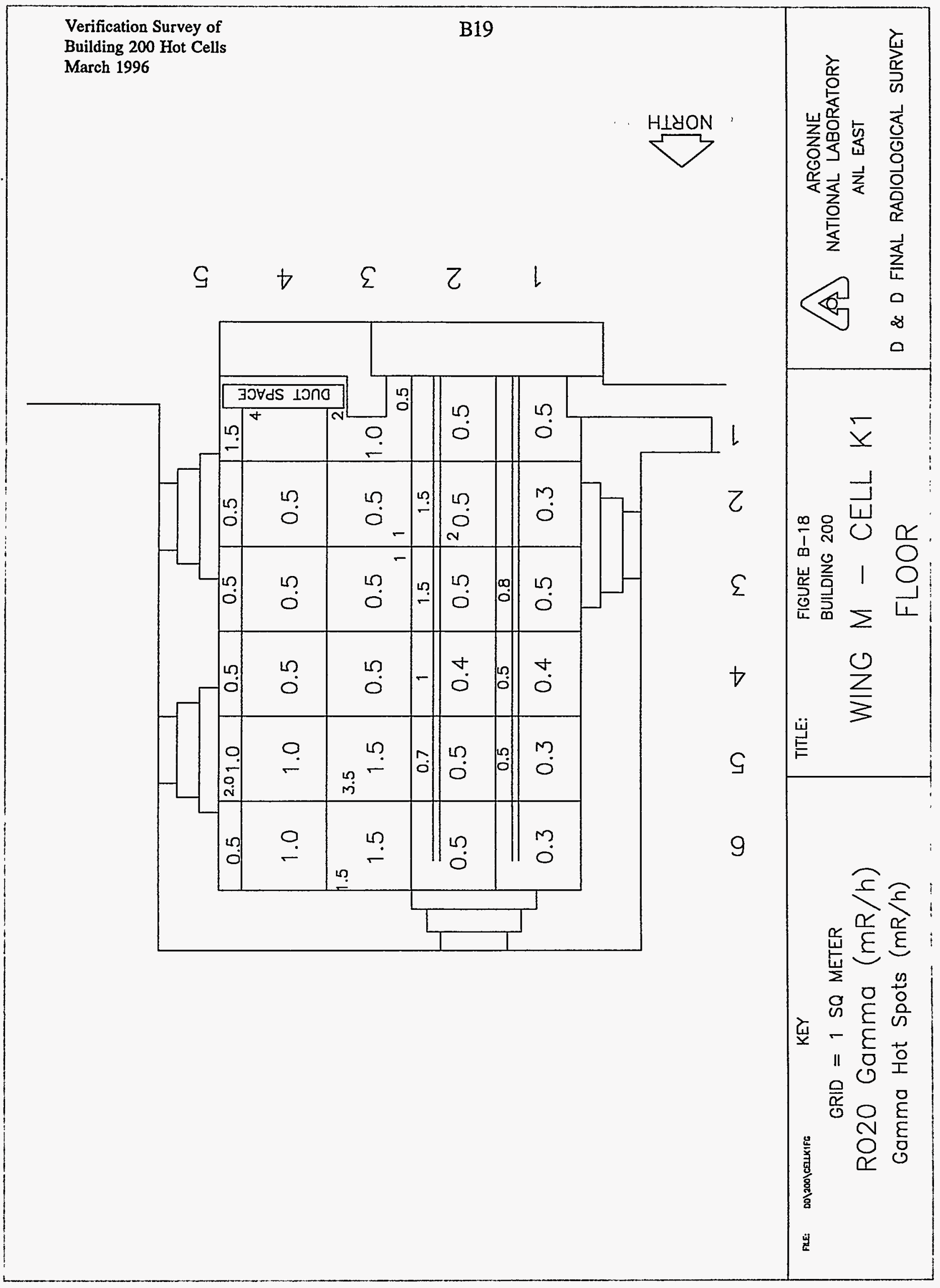




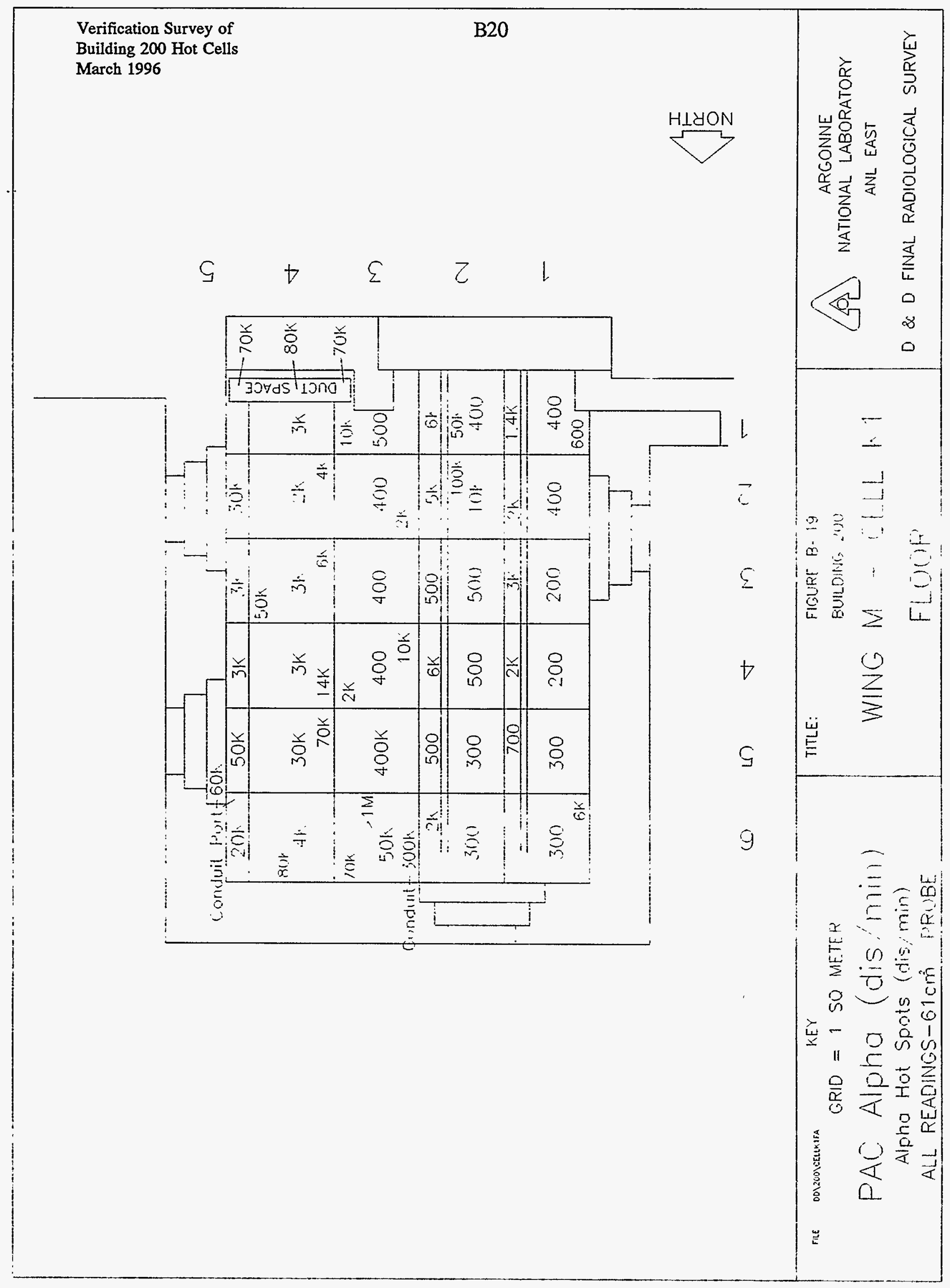




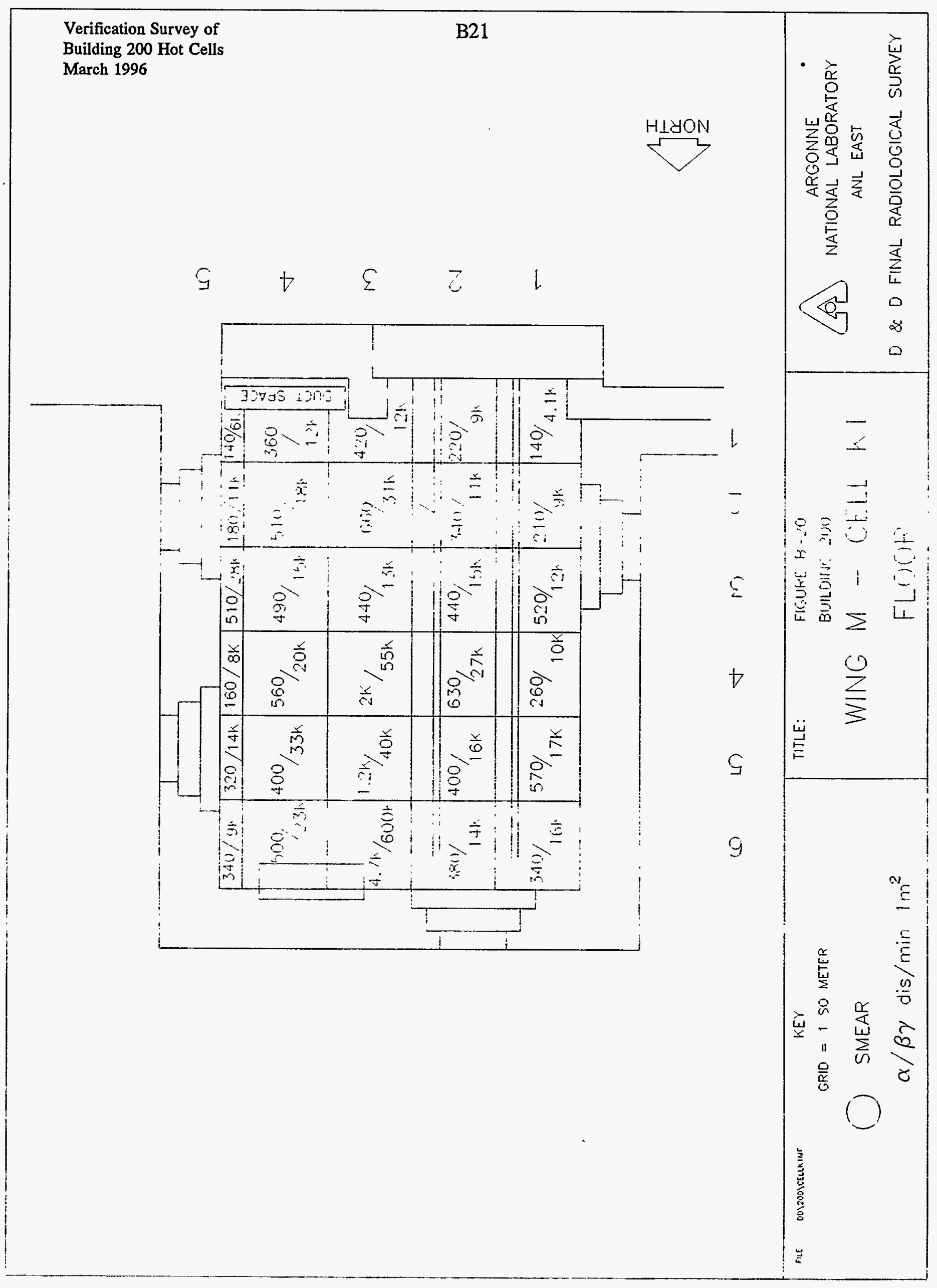




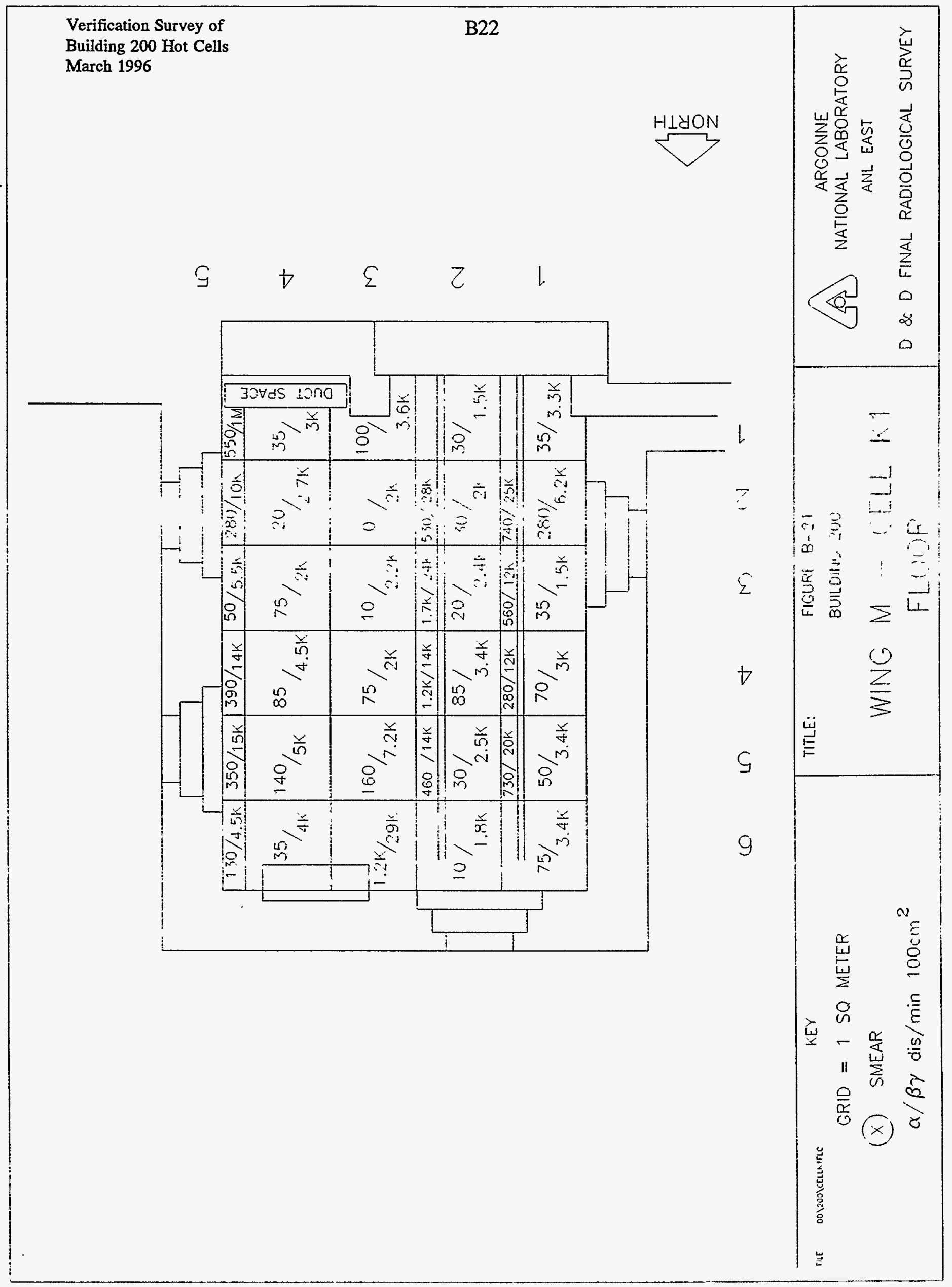




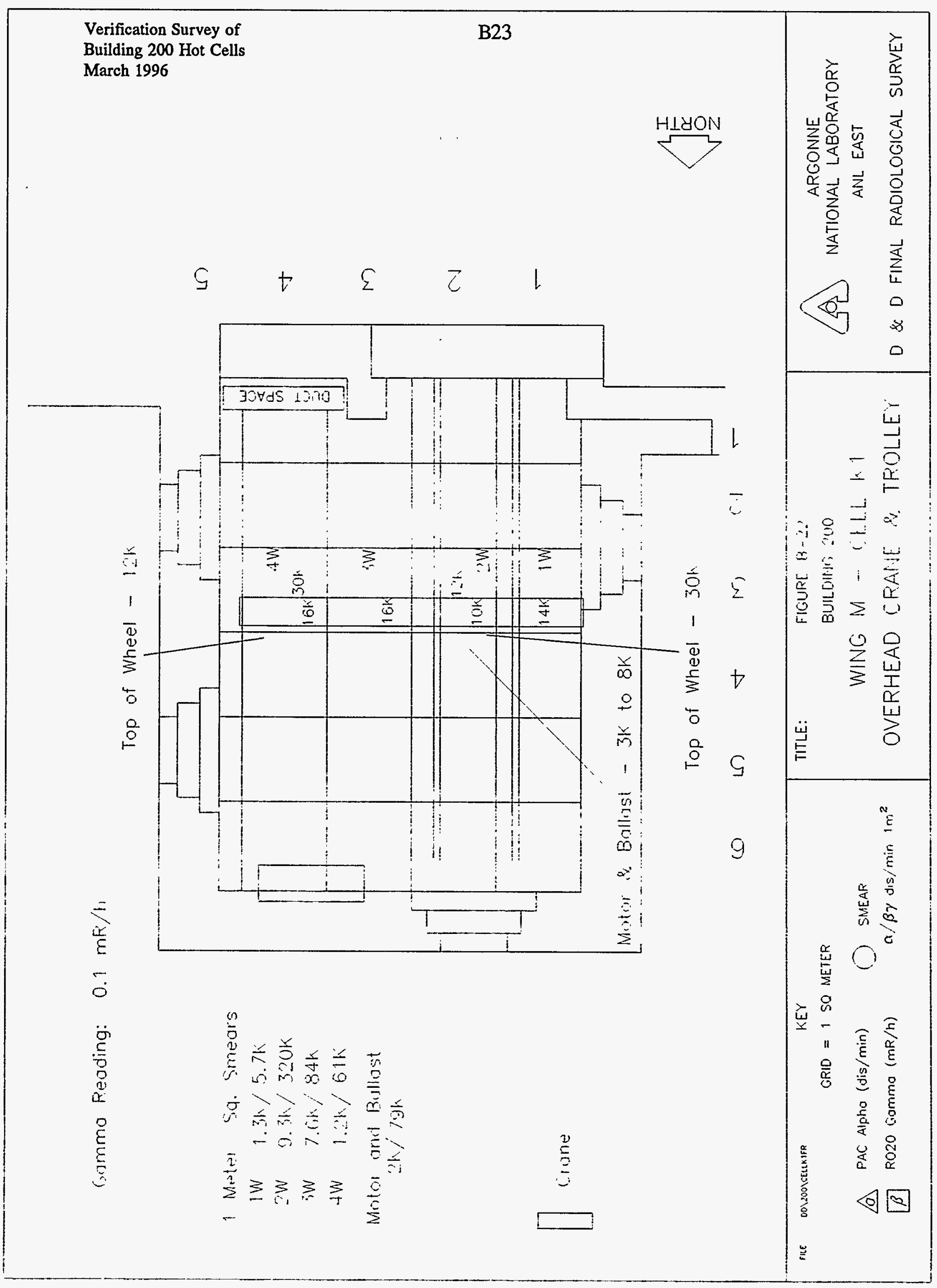




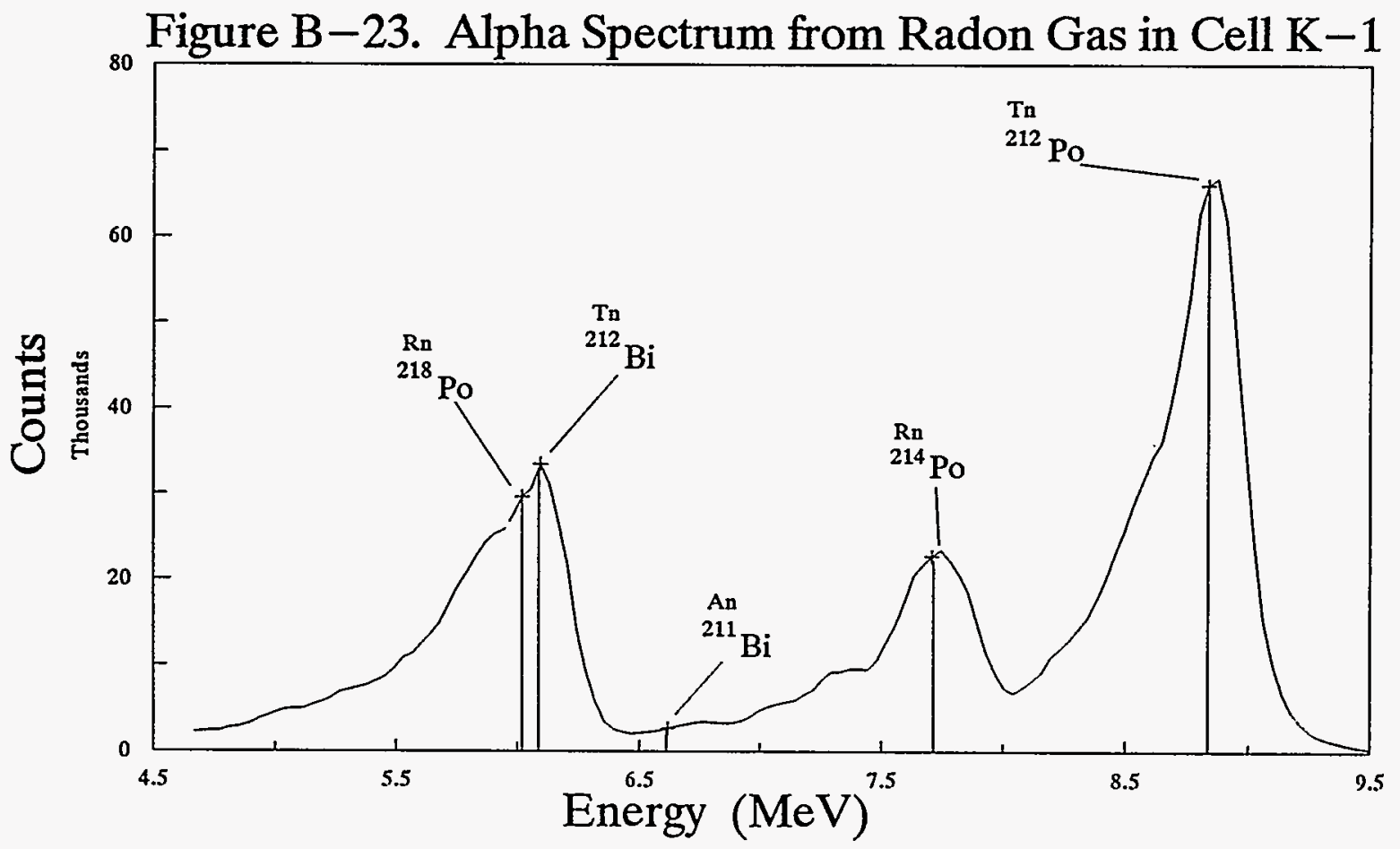

Figure B-24. Alpha-6 Rn \& Tn Activities in Cell K-1

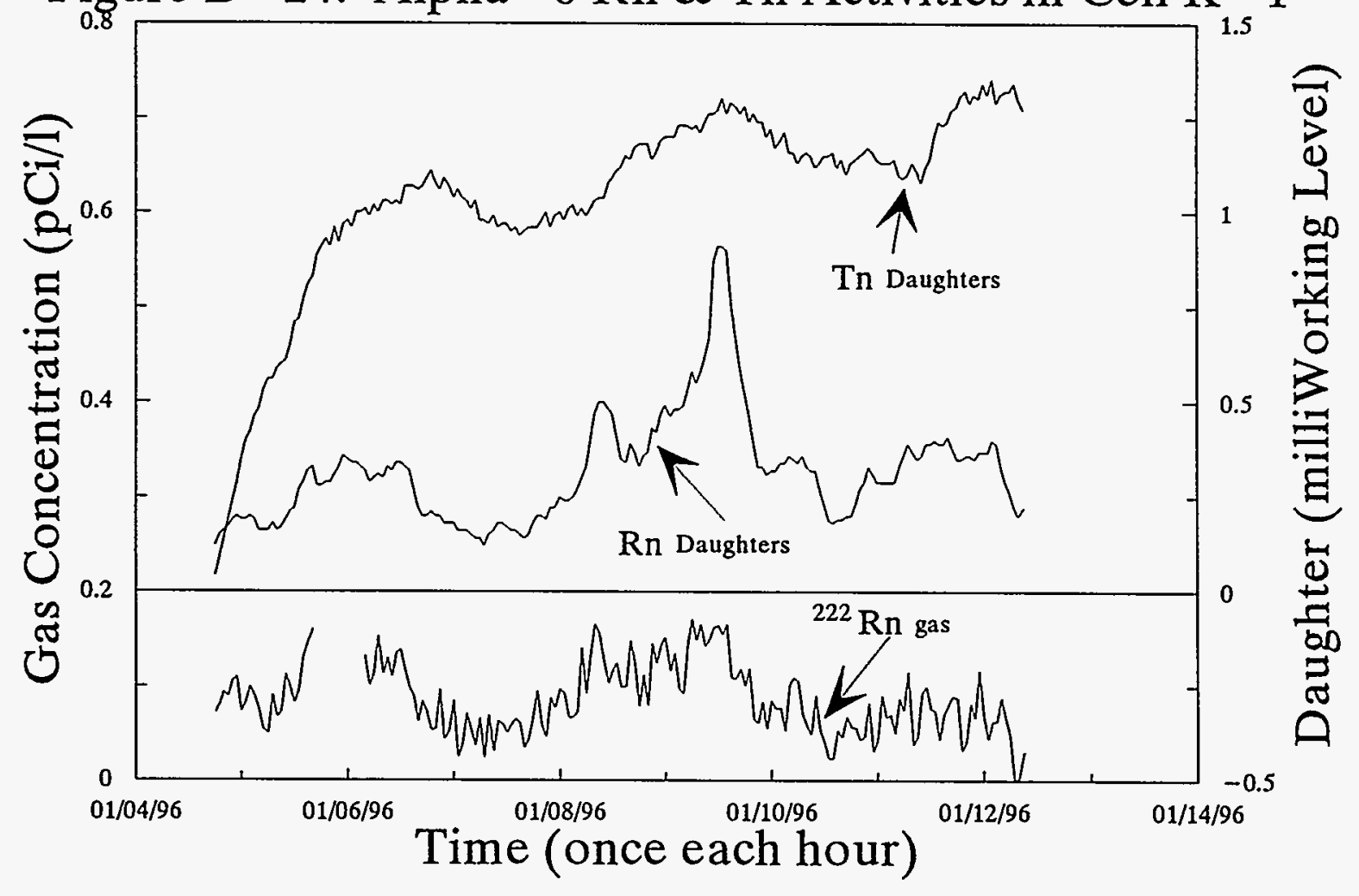




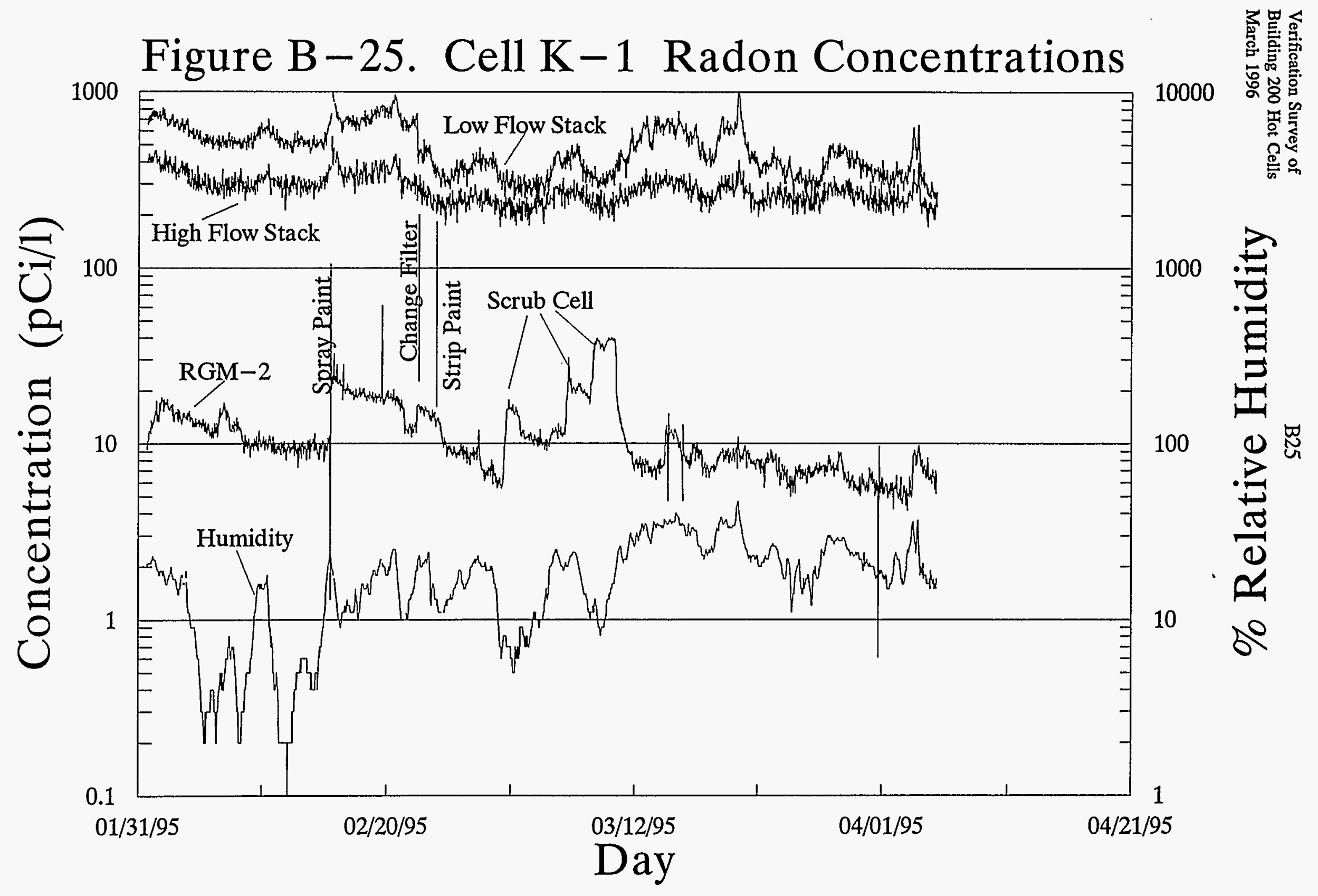




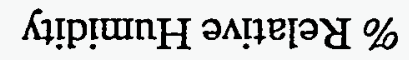

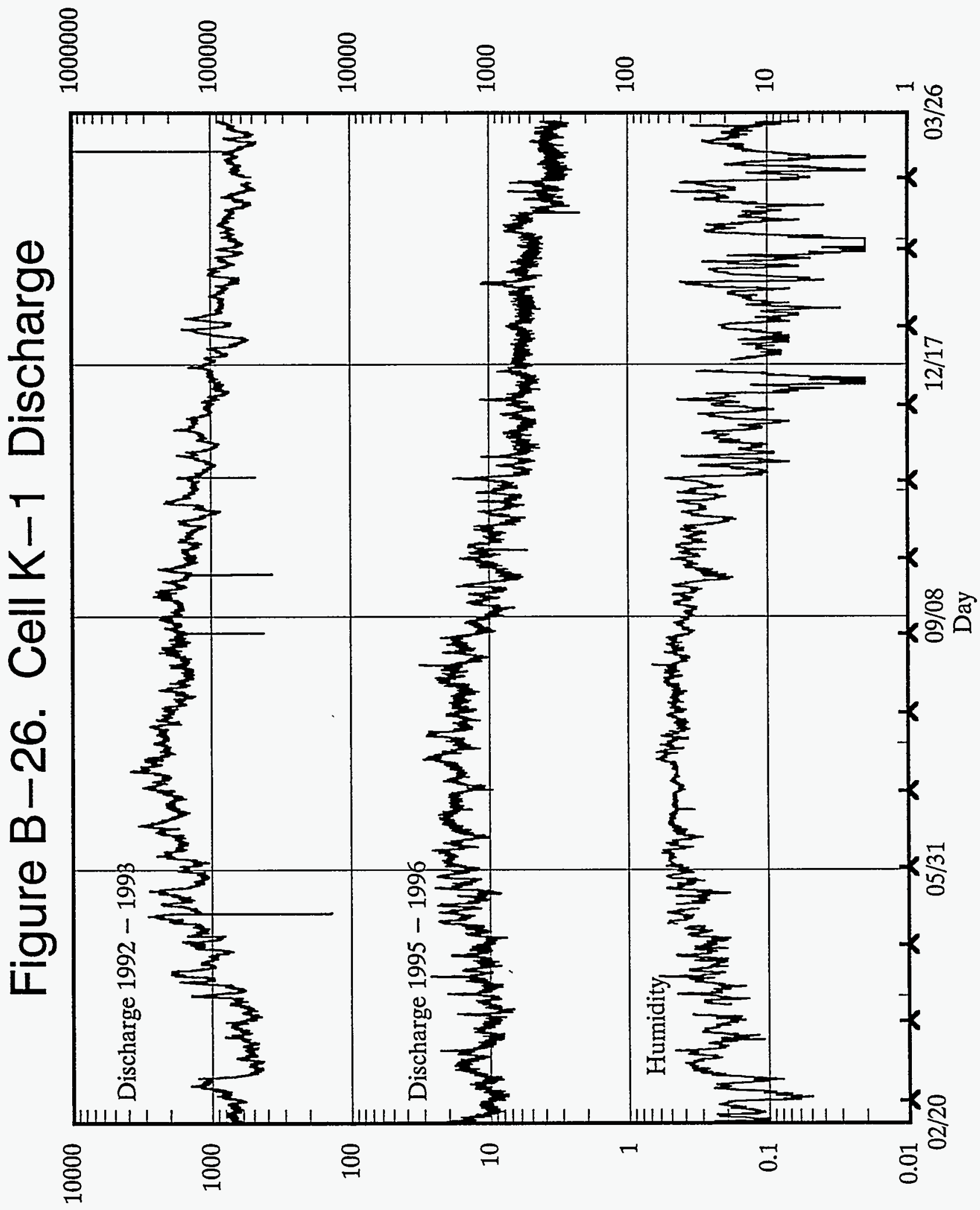

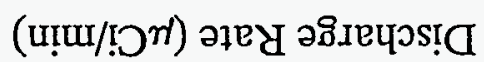


Verification Survey of

Building 200 Hot Cells

March 1996 


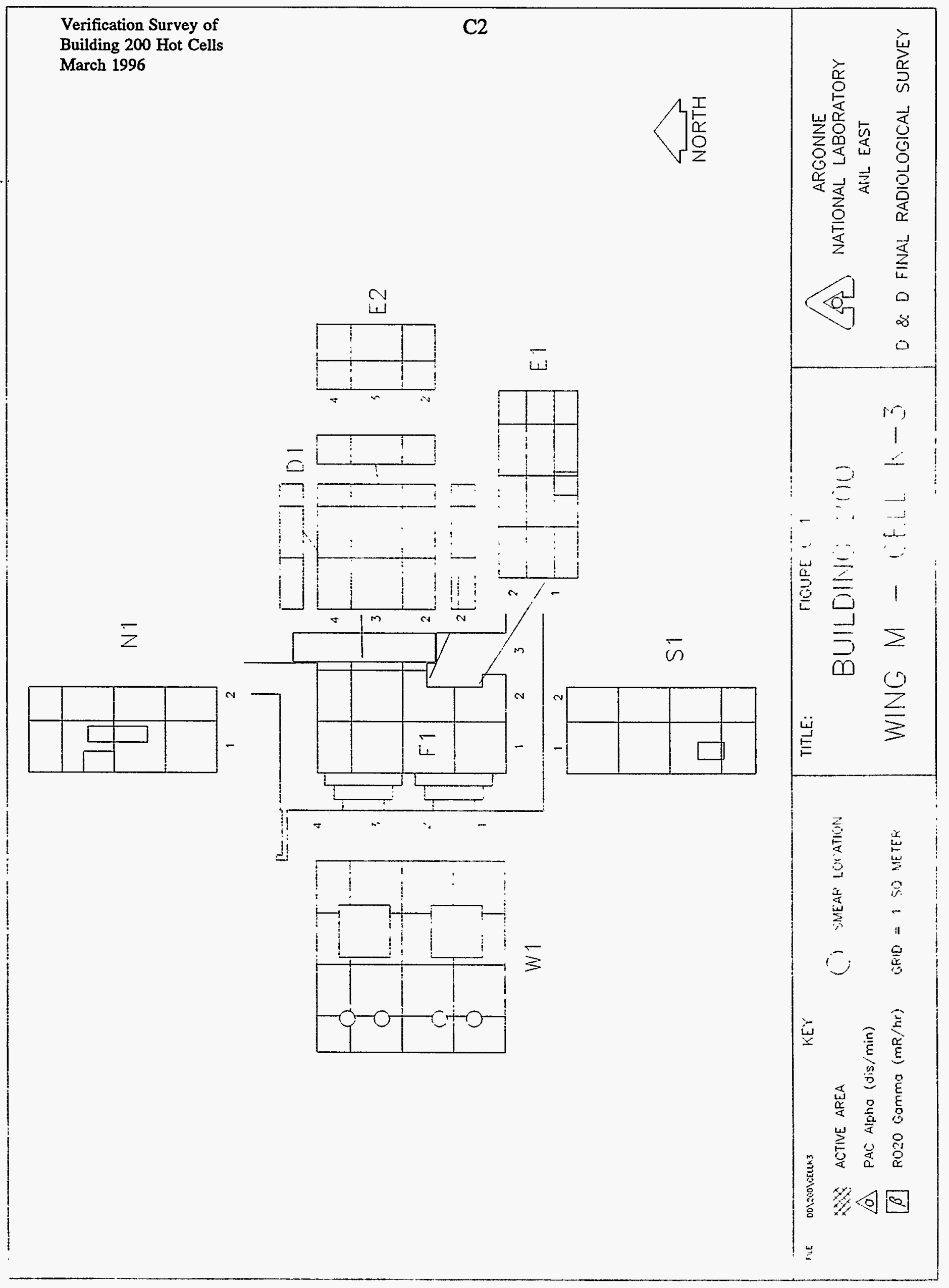




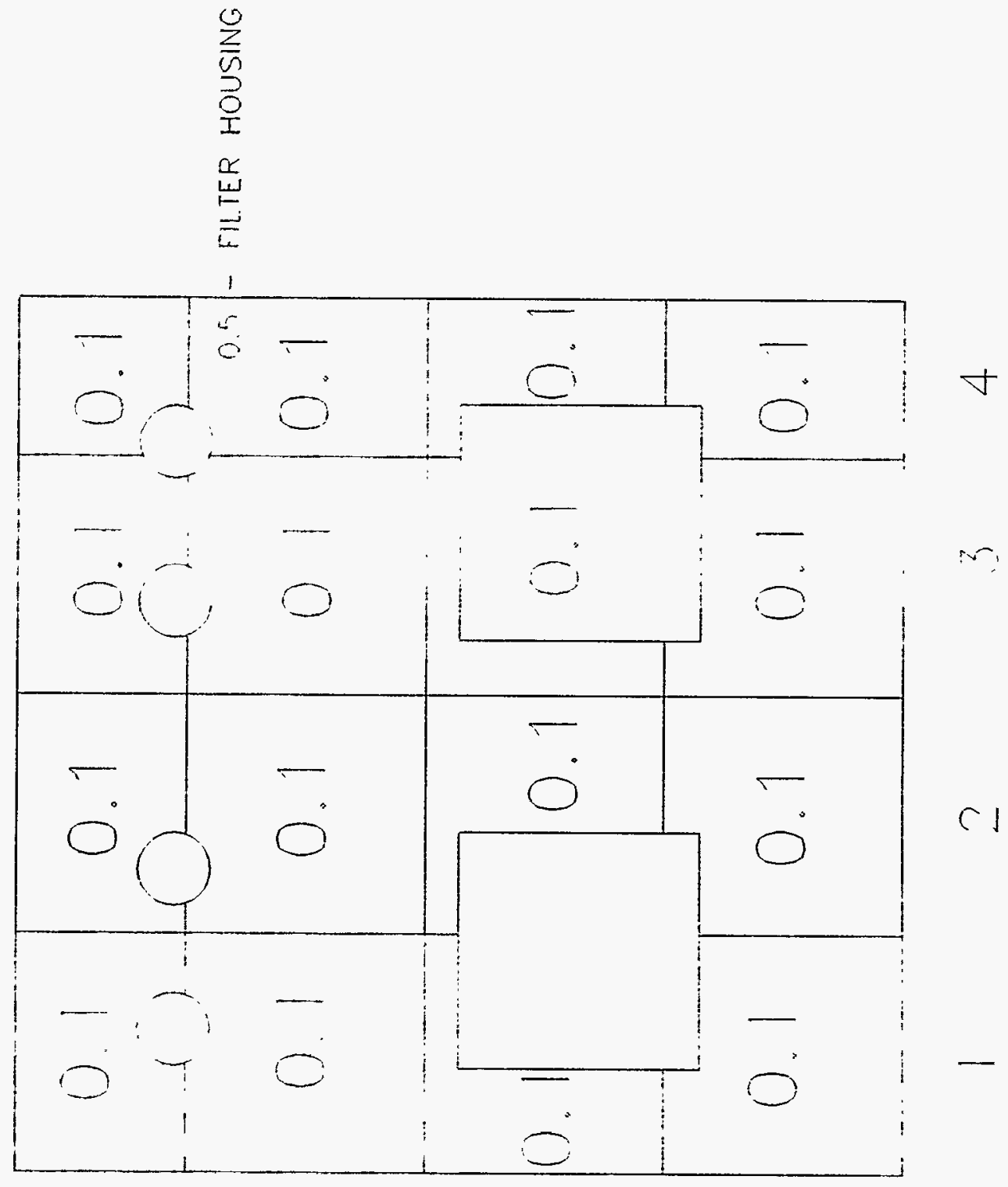



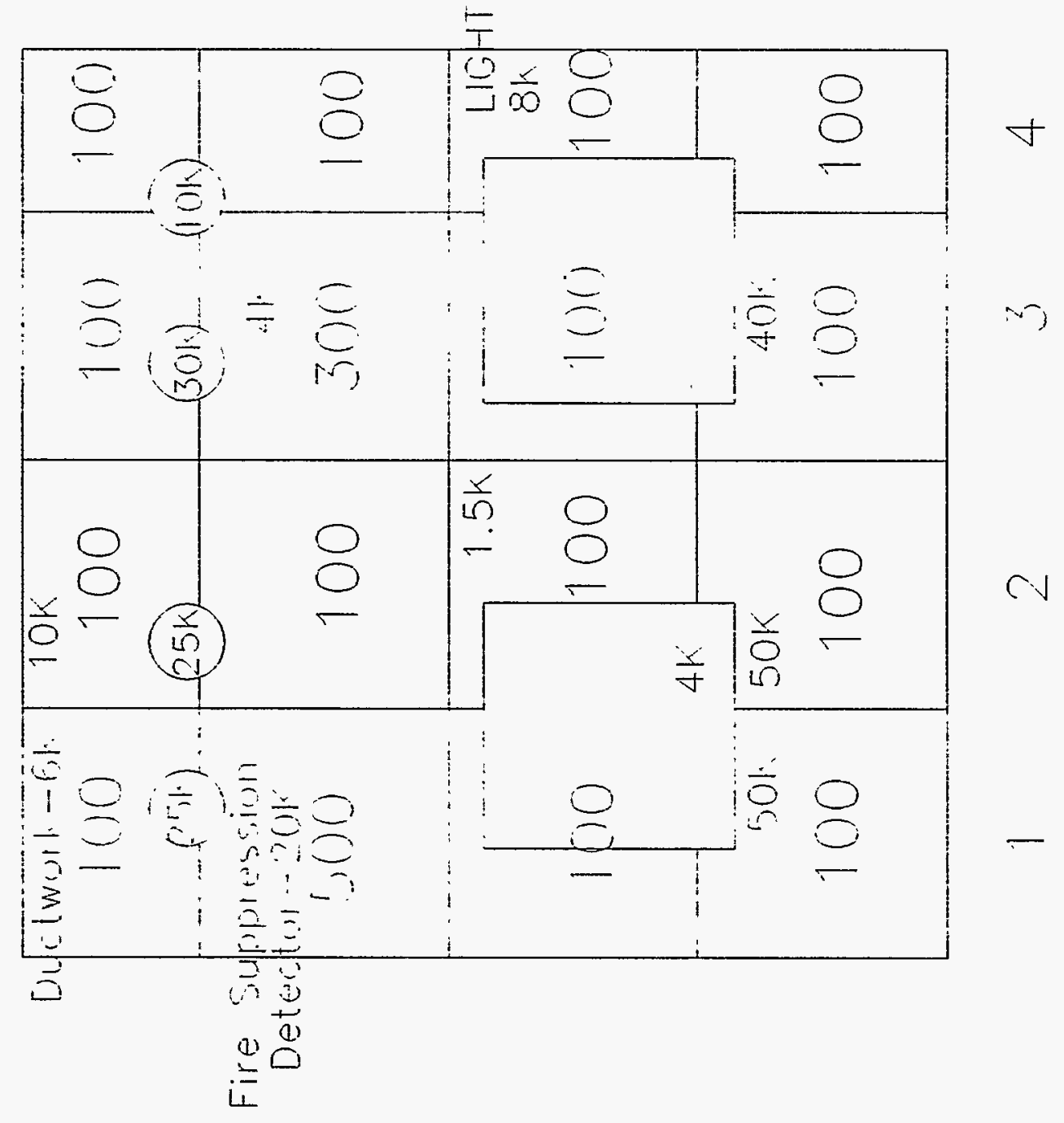


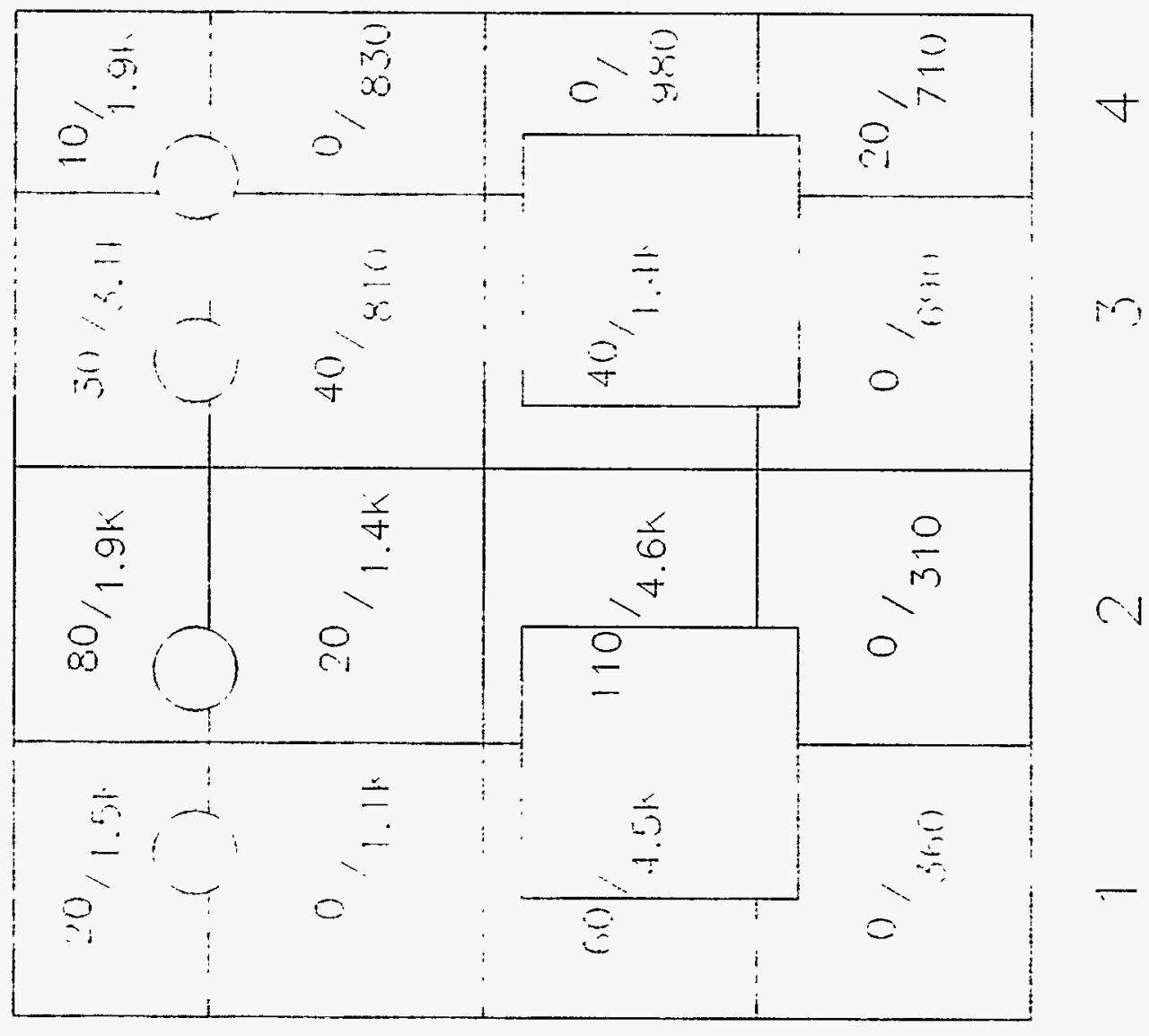



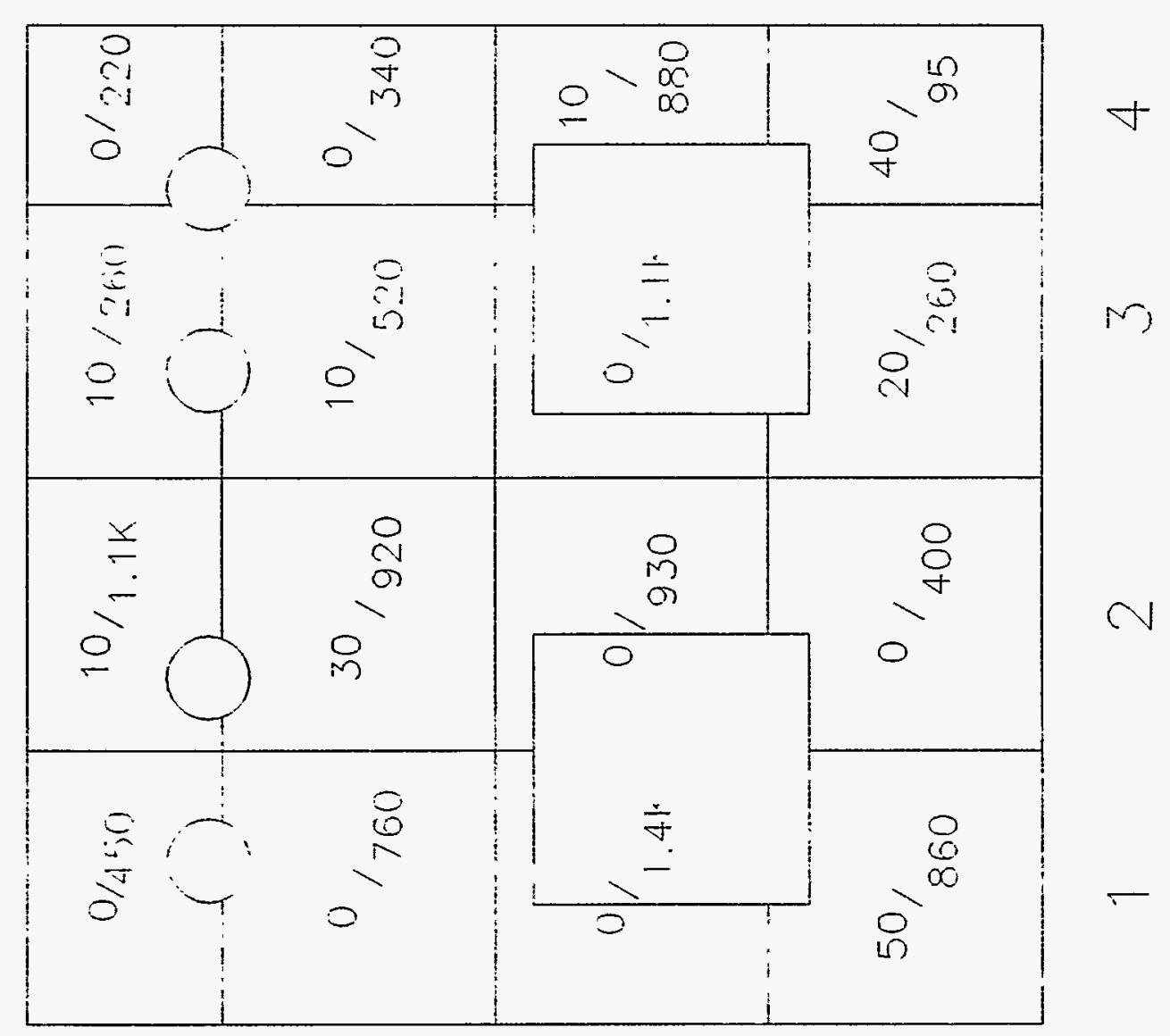

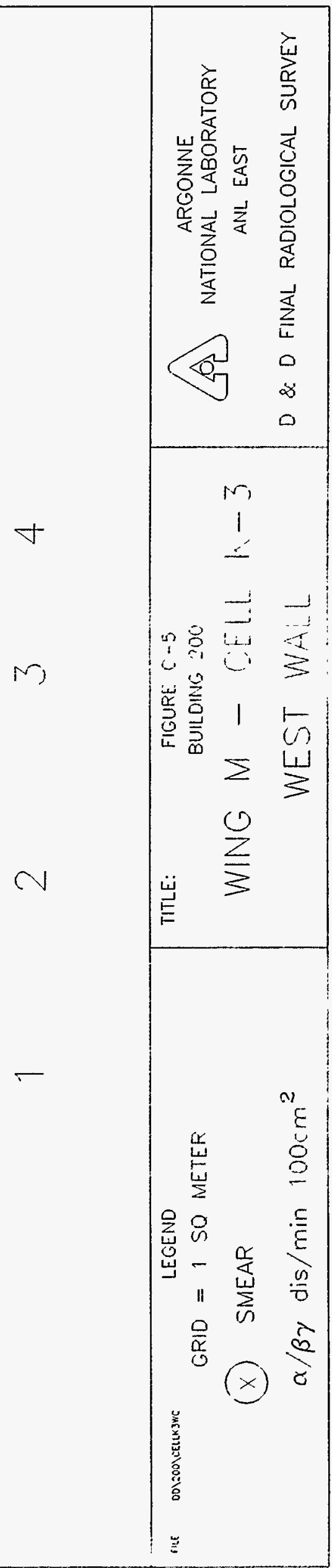




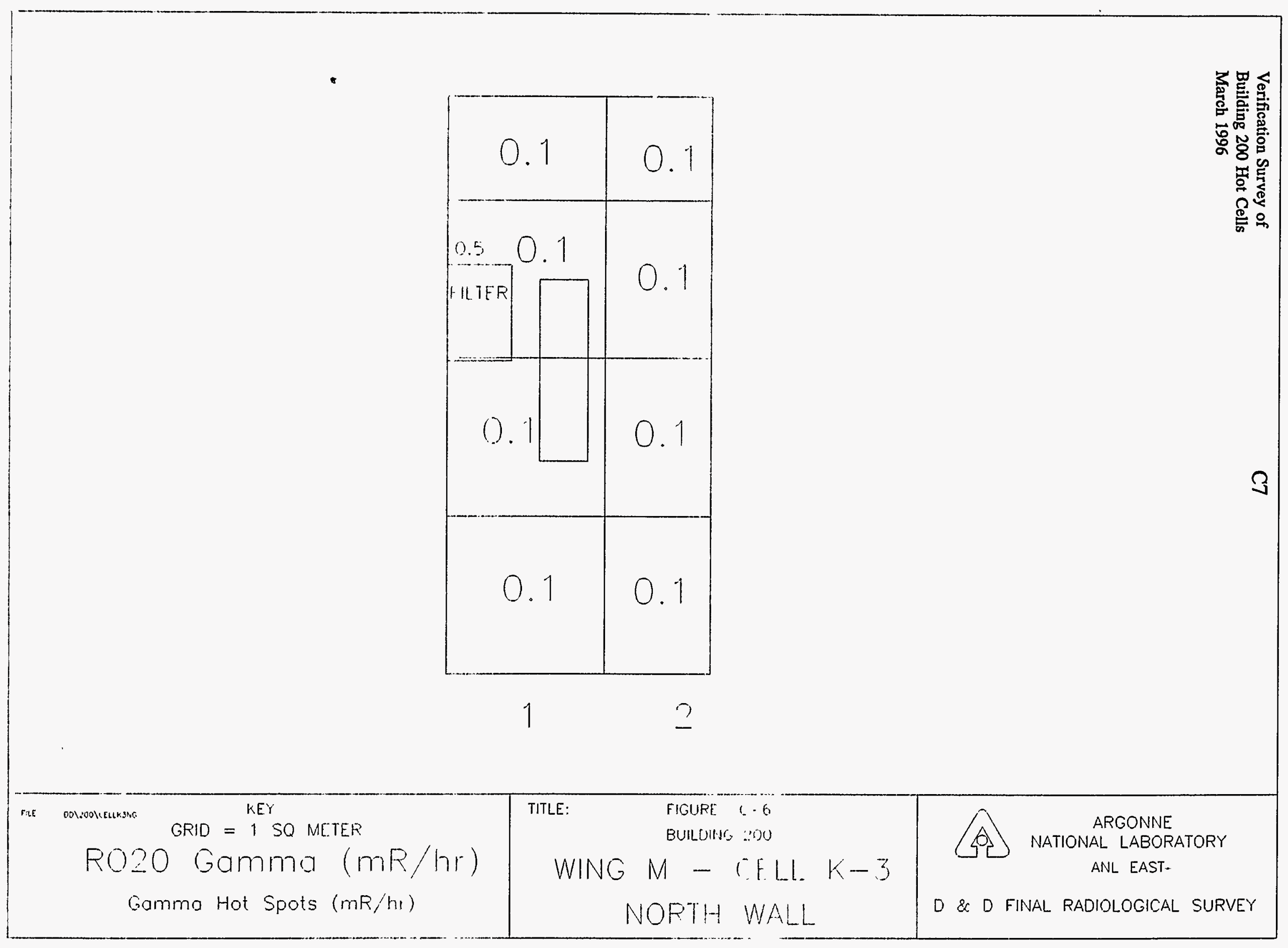



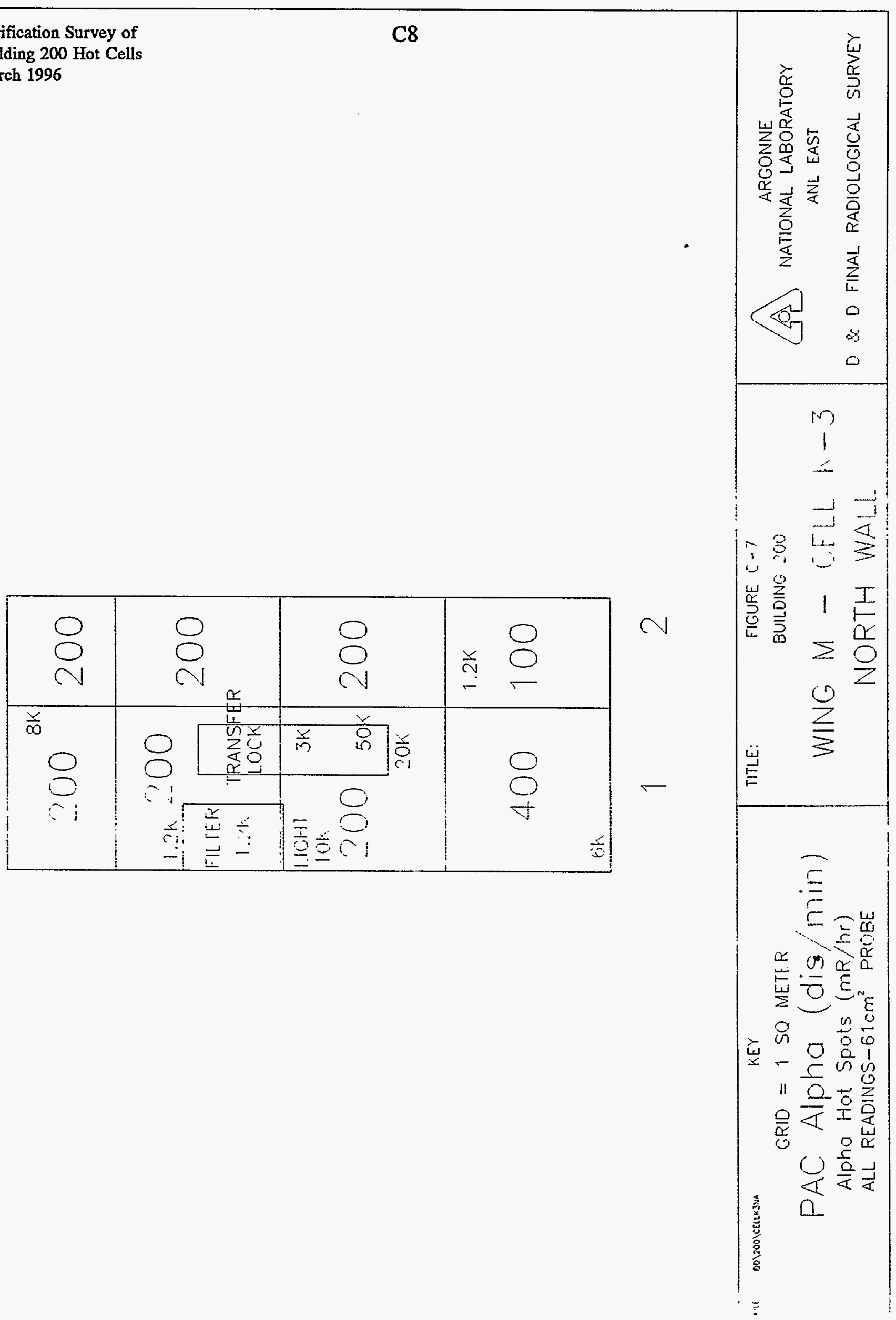


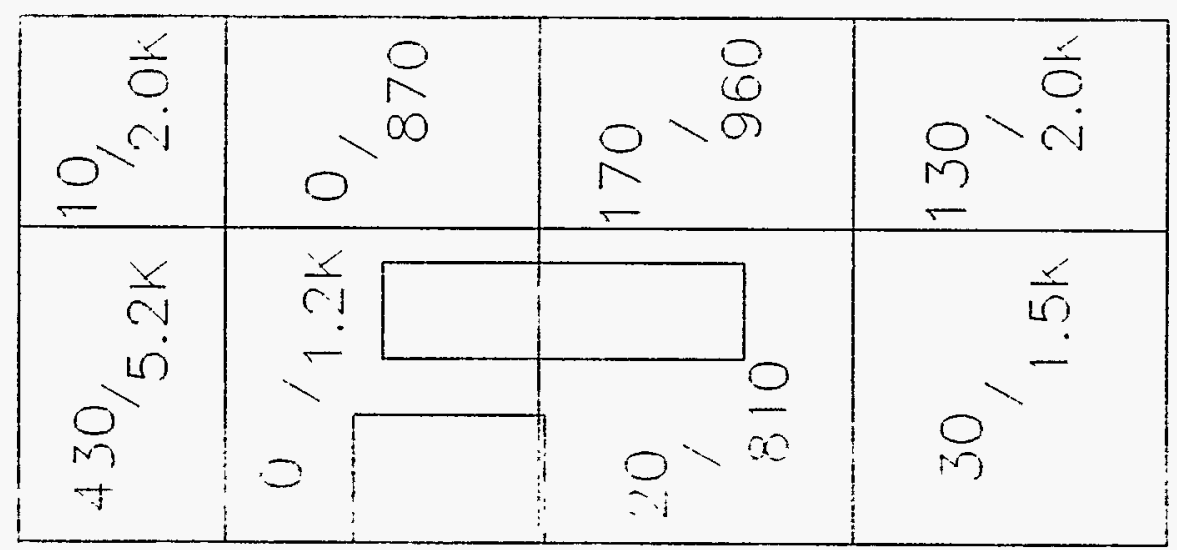

$\mathrm{CJ}$

$\underset{1}{\infty} \stackrel{3}{\vdots}$

崩

岕总

는

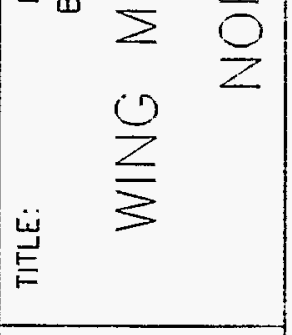

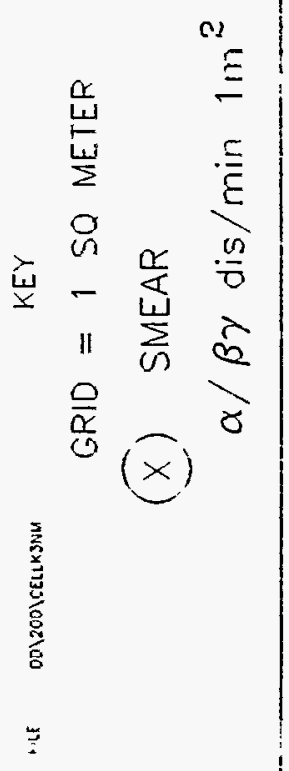




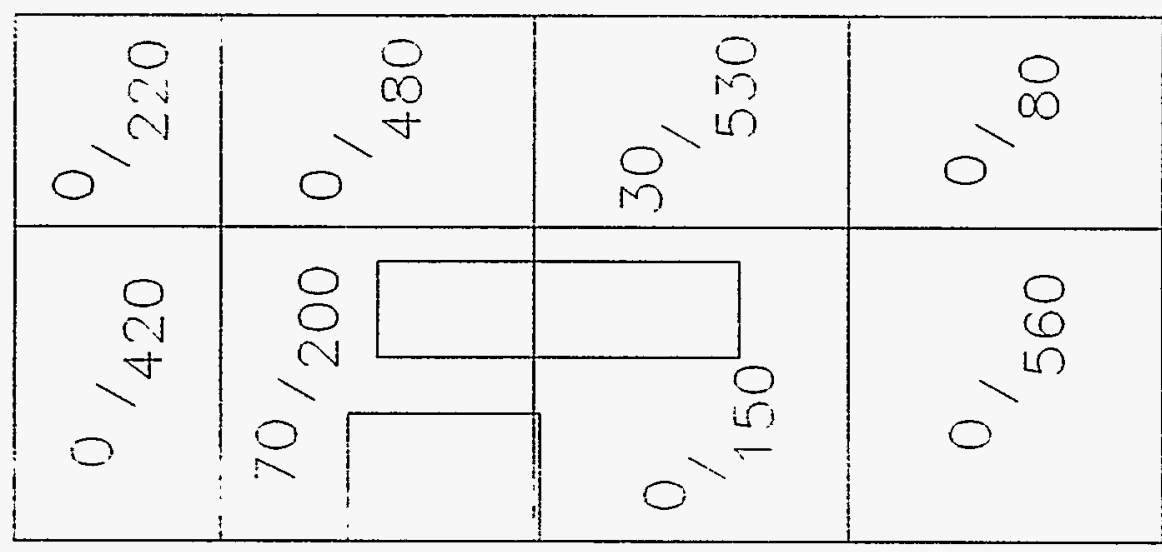

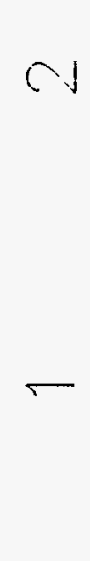

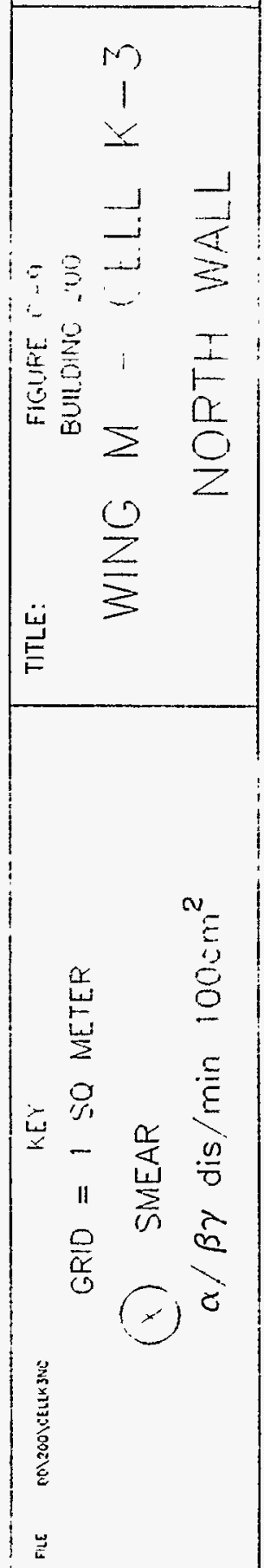




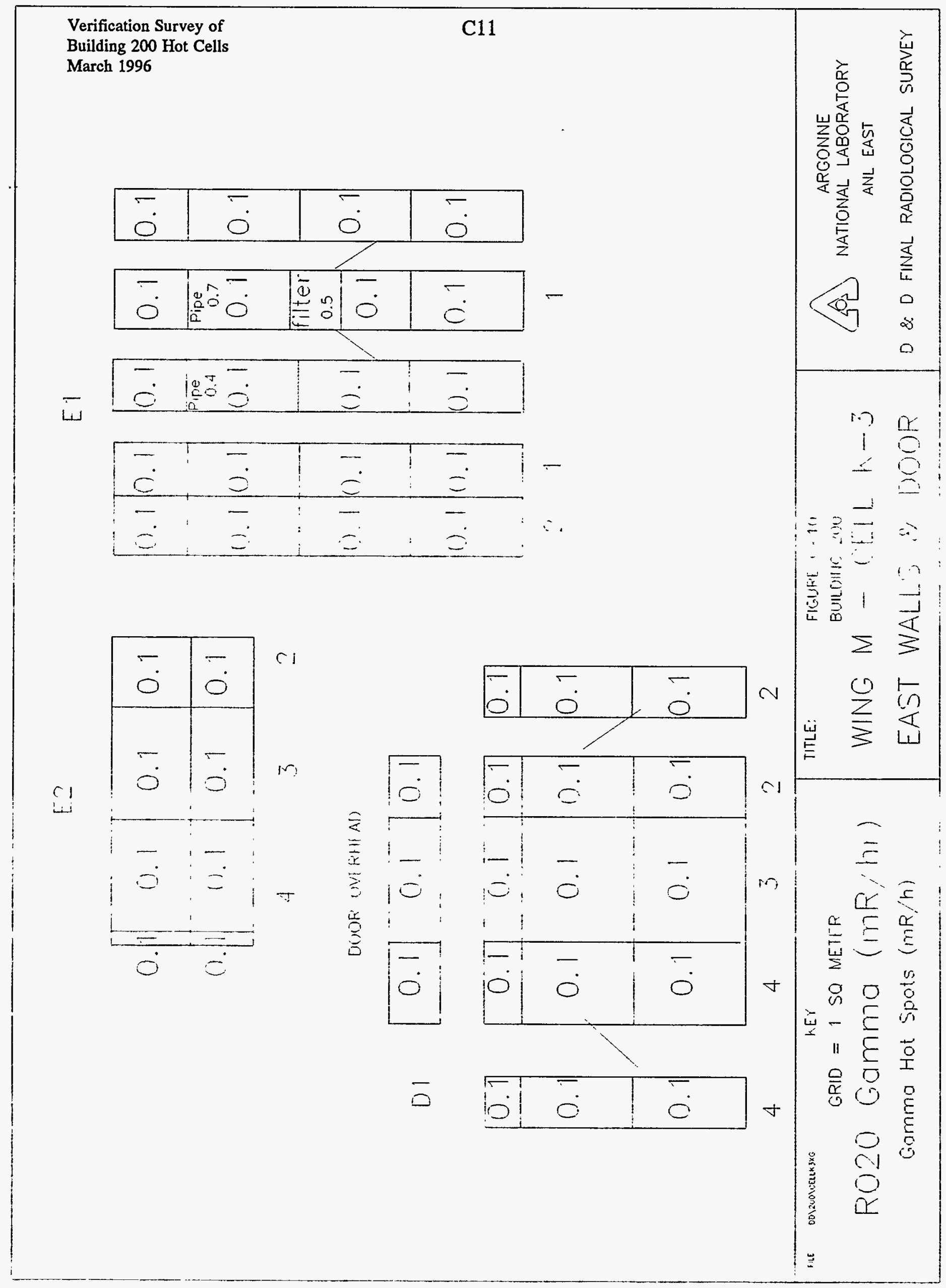




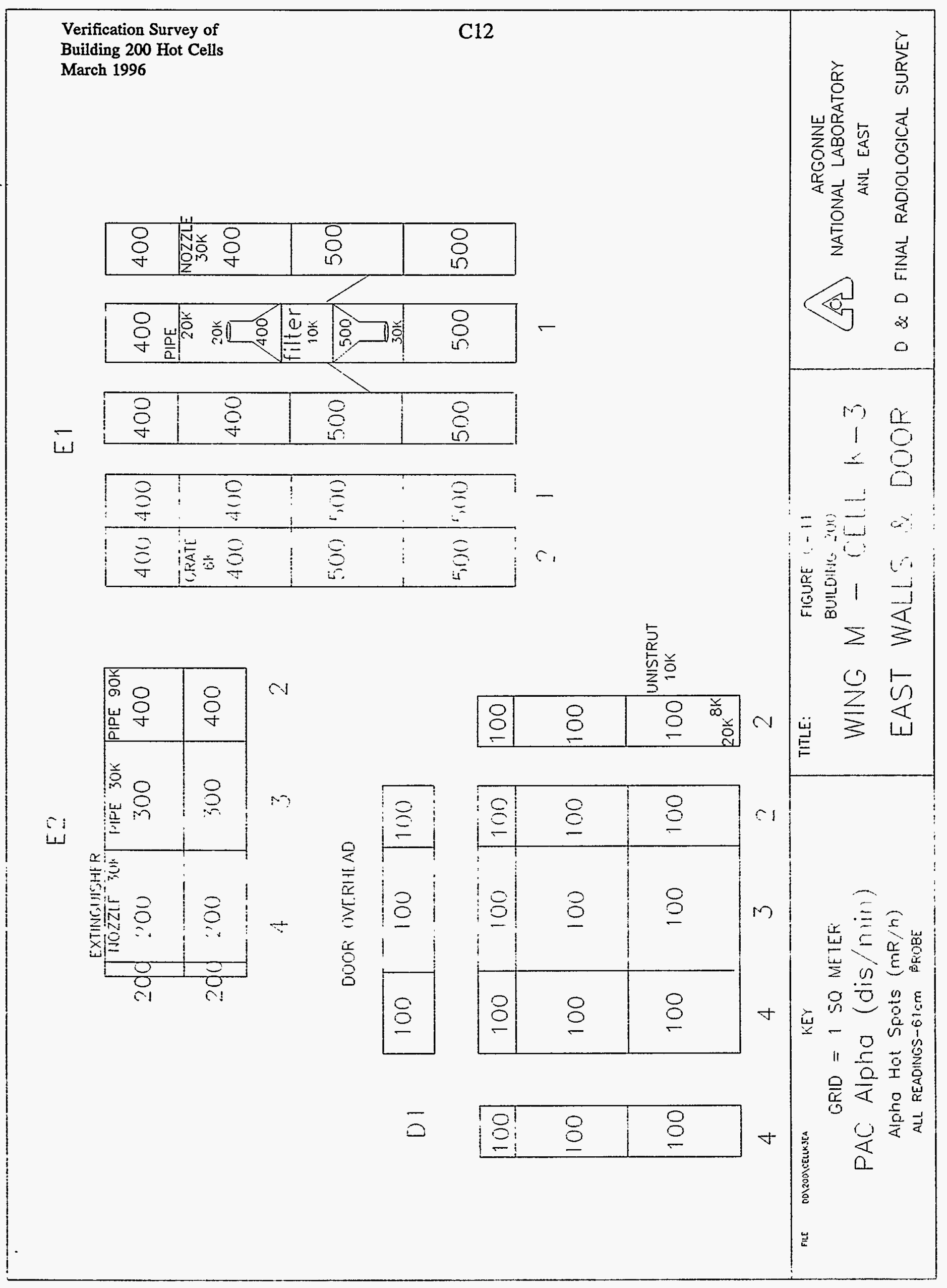




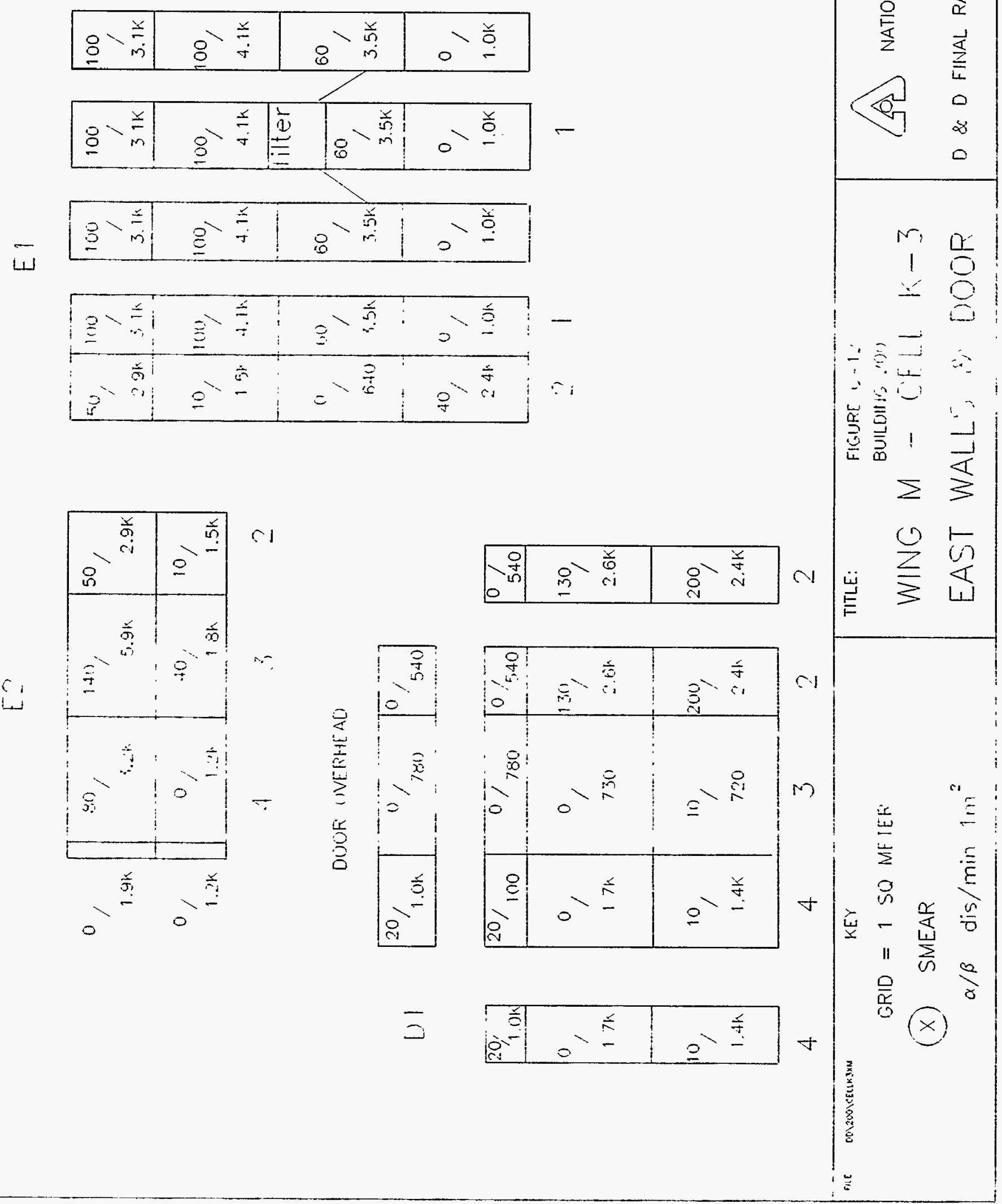




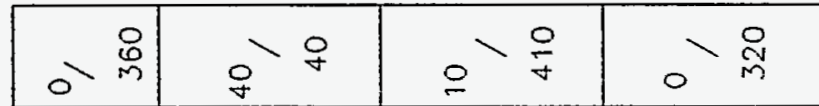

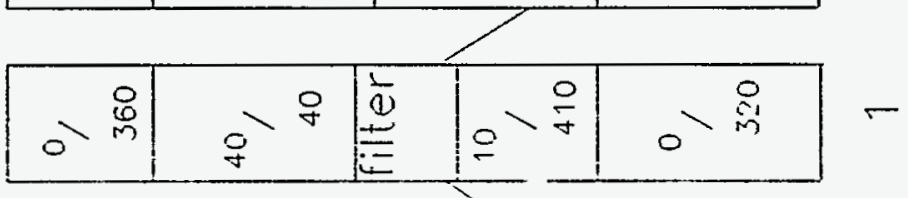

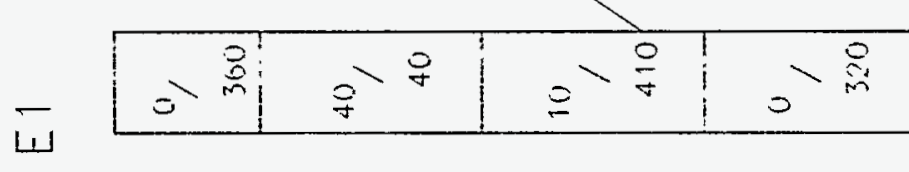

\begin{tabular}{|c|c|c|c|}
\hline$=8 !$ & $\cong$ 于 & $\therefore \frac{9}{4}$ & 28 \\
\hline$e^{-\frac{0}{y}}$ & $=\stackrel{3}{\circ}$ & $=\frac{P}{I}$ & 亦 \\
\hline
\end{tabular}
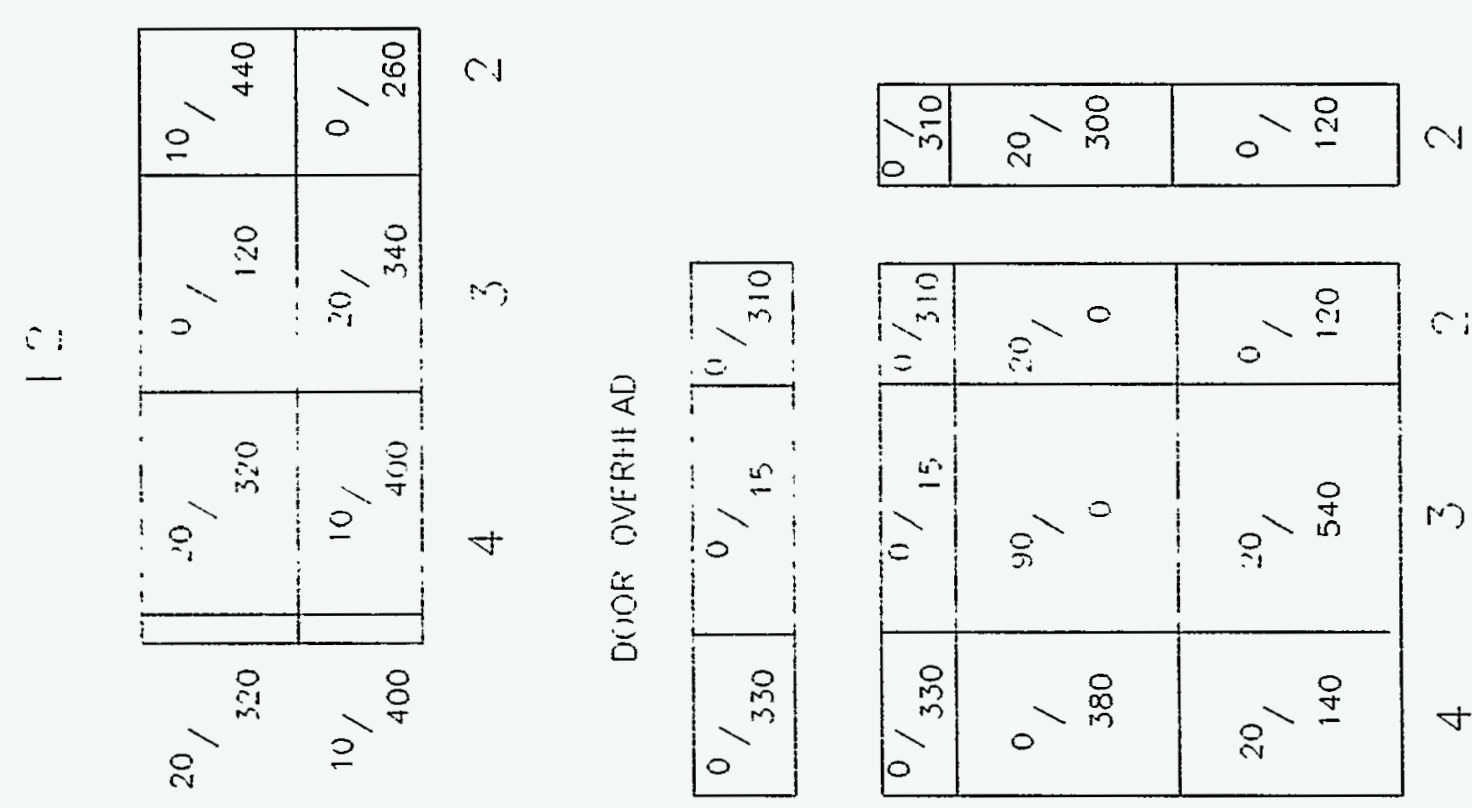

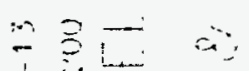

'心 '-

炭言 $\Sigma \xi$

\begin{tabular}{|c|c|c|}
\hline $\begin{array}{l}0 \\
\therefore \\
=\end{array}$ & $\varepsilon^{\circ}$ & $0^{-\stackrel{i}{I}}$ \\
\hline$\therefore$ & $\hat{j}^{\circ}$ & 只 \\
\hline $\begin{array}{c}0 \\
m \\
0\end{array}$ & $0^{\backslash}$ & 일 \\
\hline
\end{tabular}

亏 $\therefore$ 状

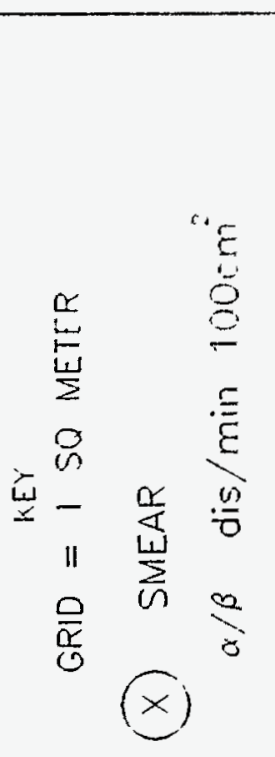



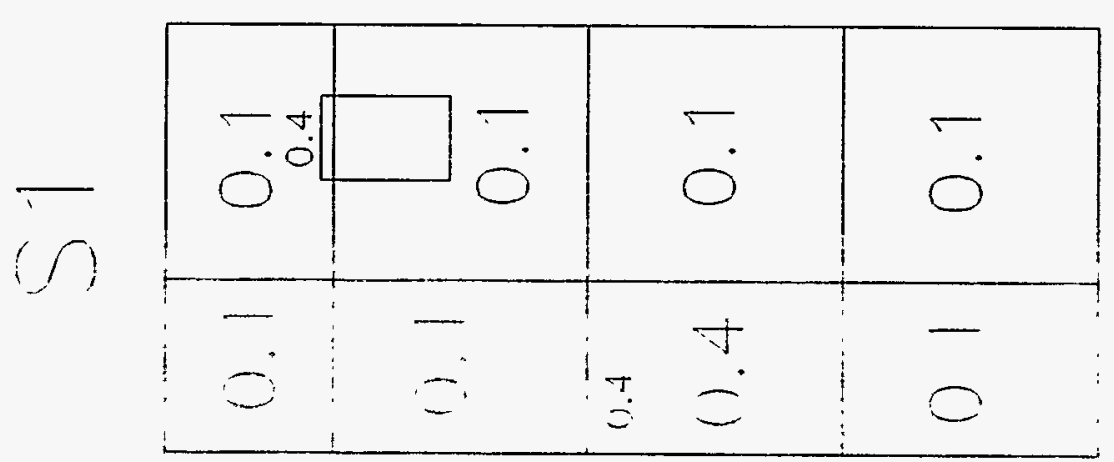

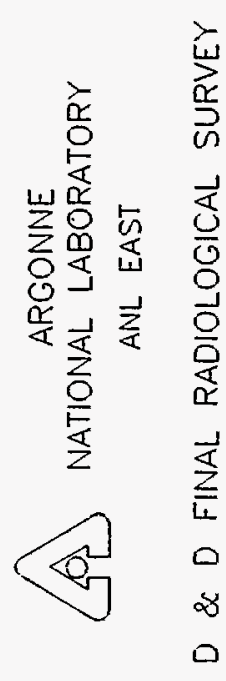

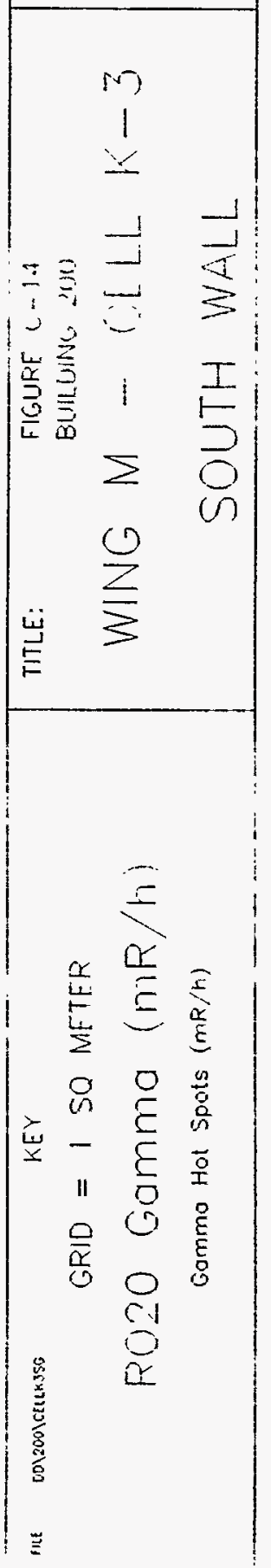




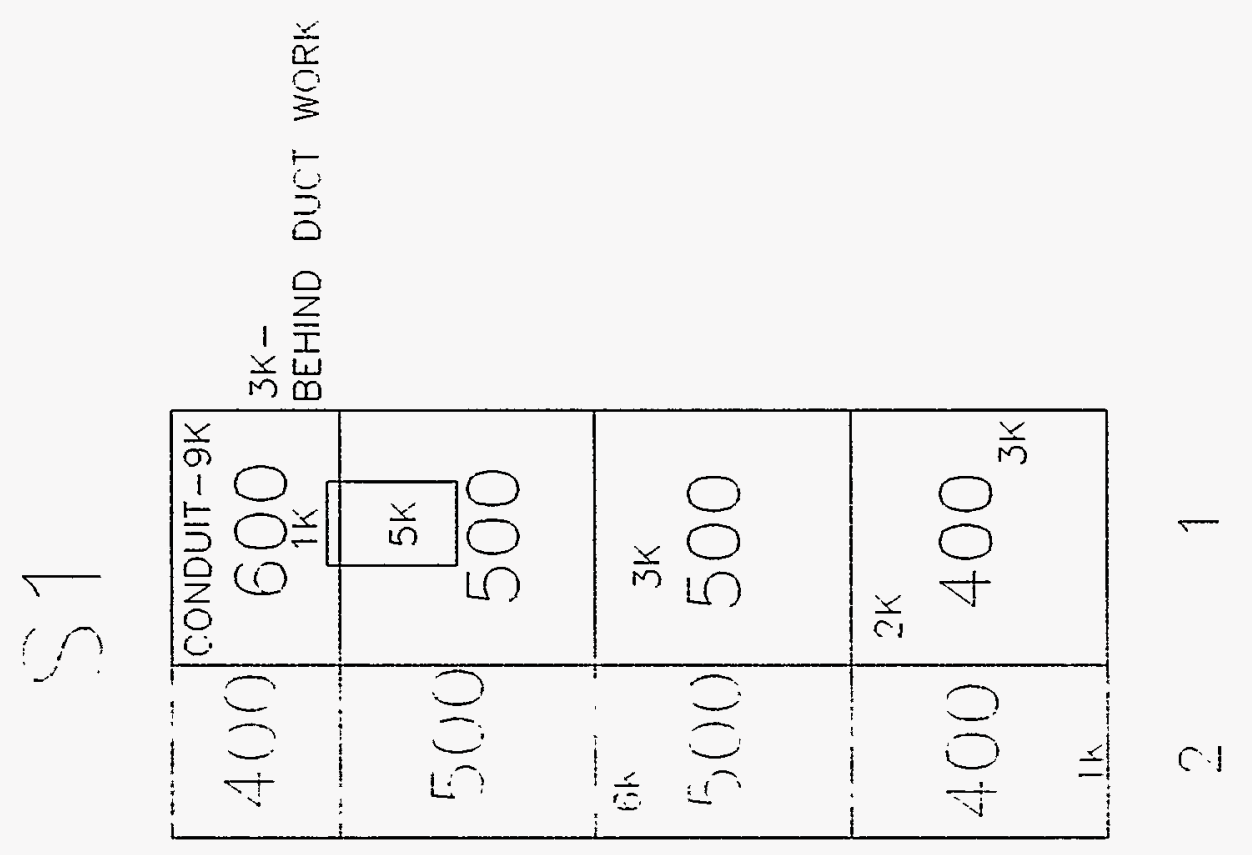

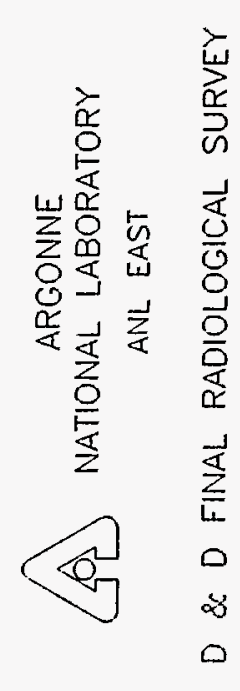

$M$

1

$\leq$

$\cong \Xi \quad \frac{1}{\sigma}$

$\therefore$ L

$\omega$

这

恶豆

은

$\sum \stackrel{0}{0}$

状

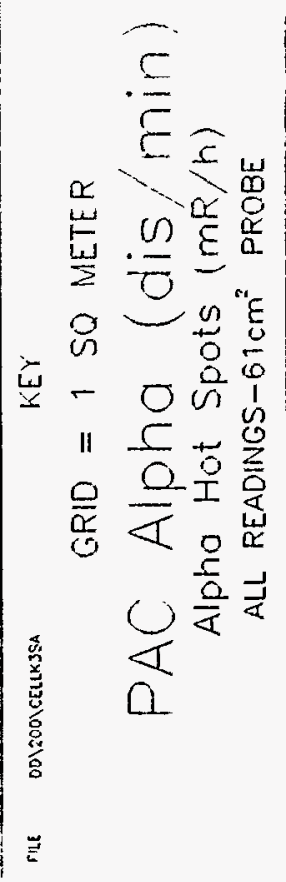




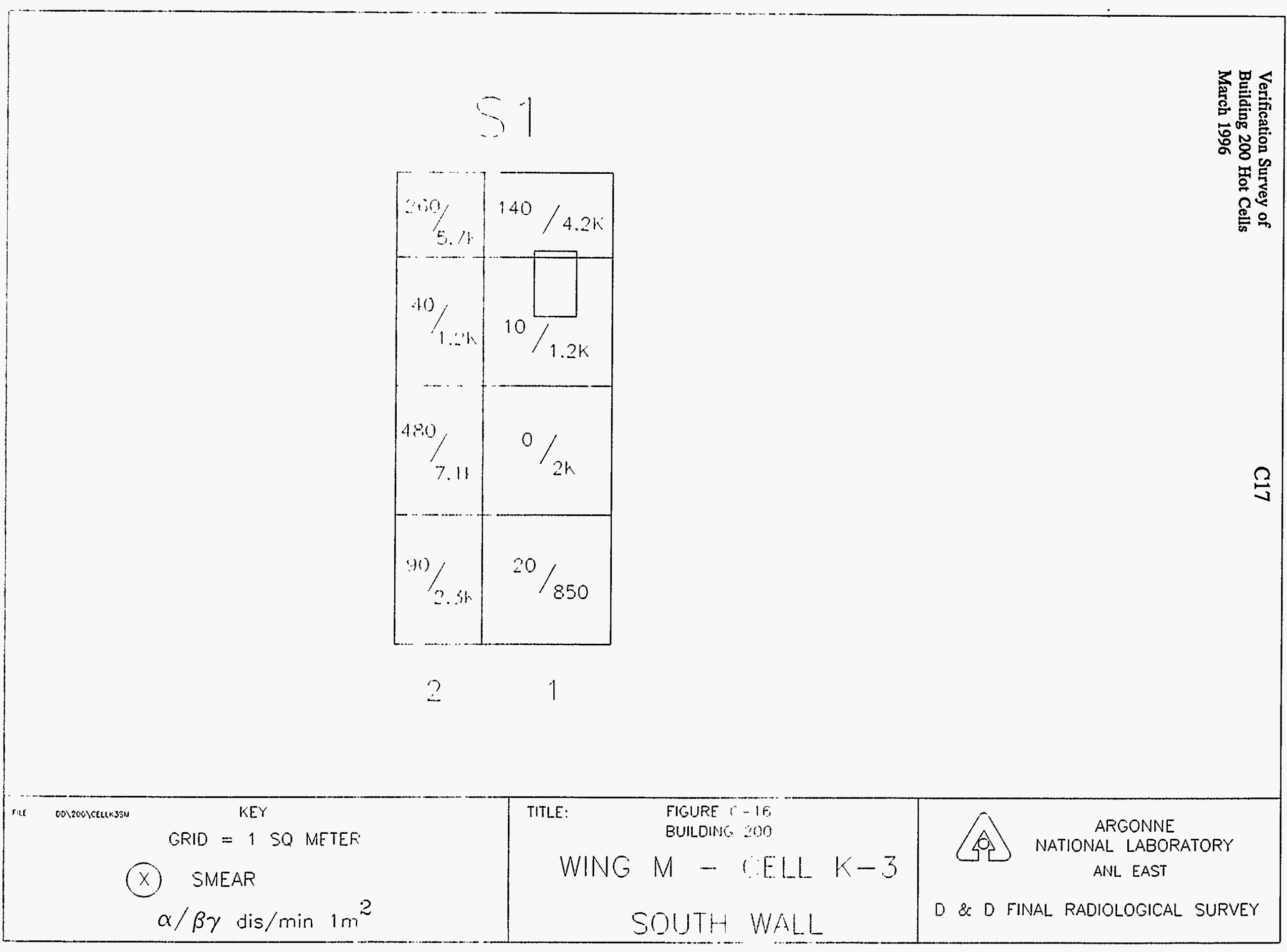



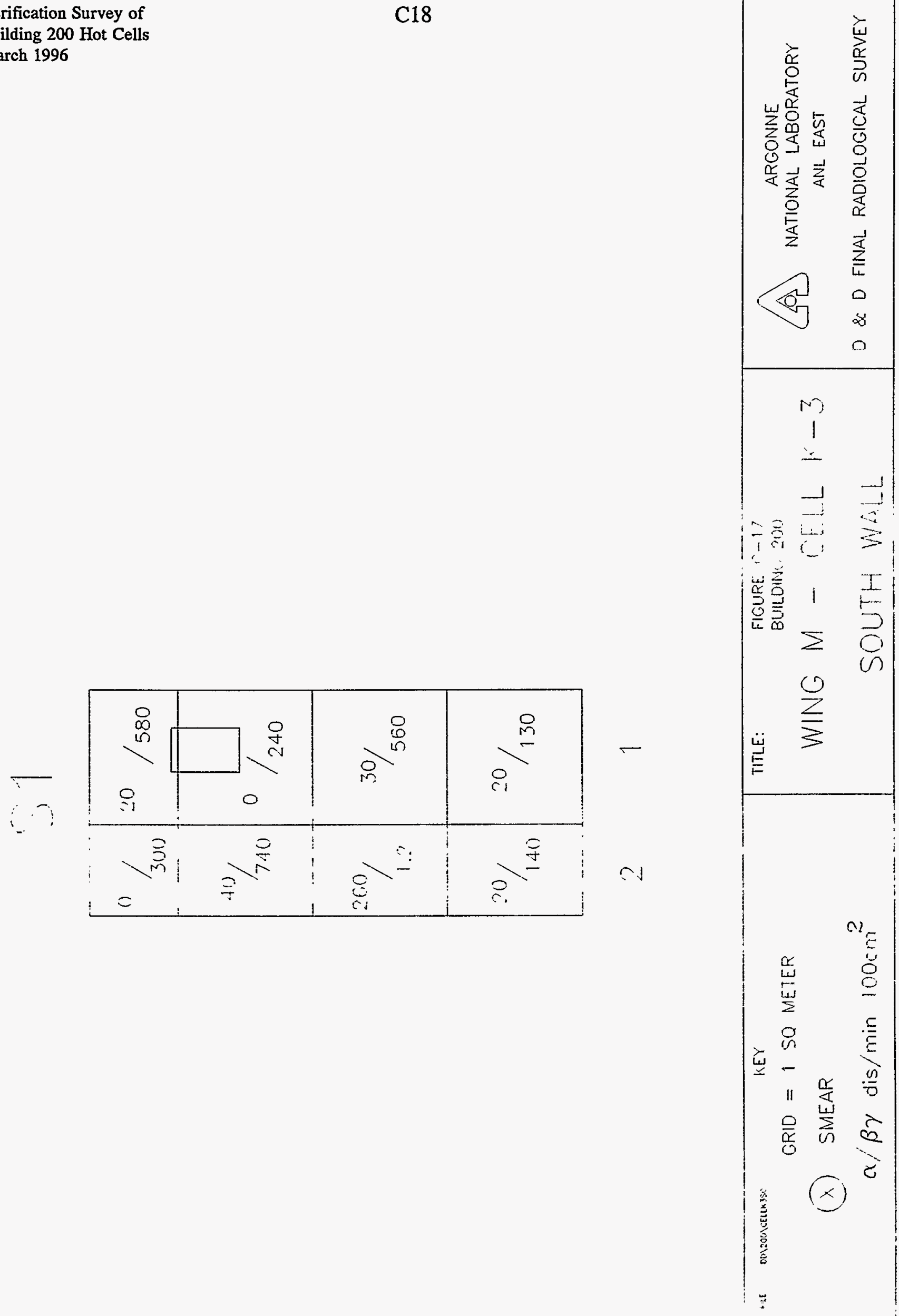


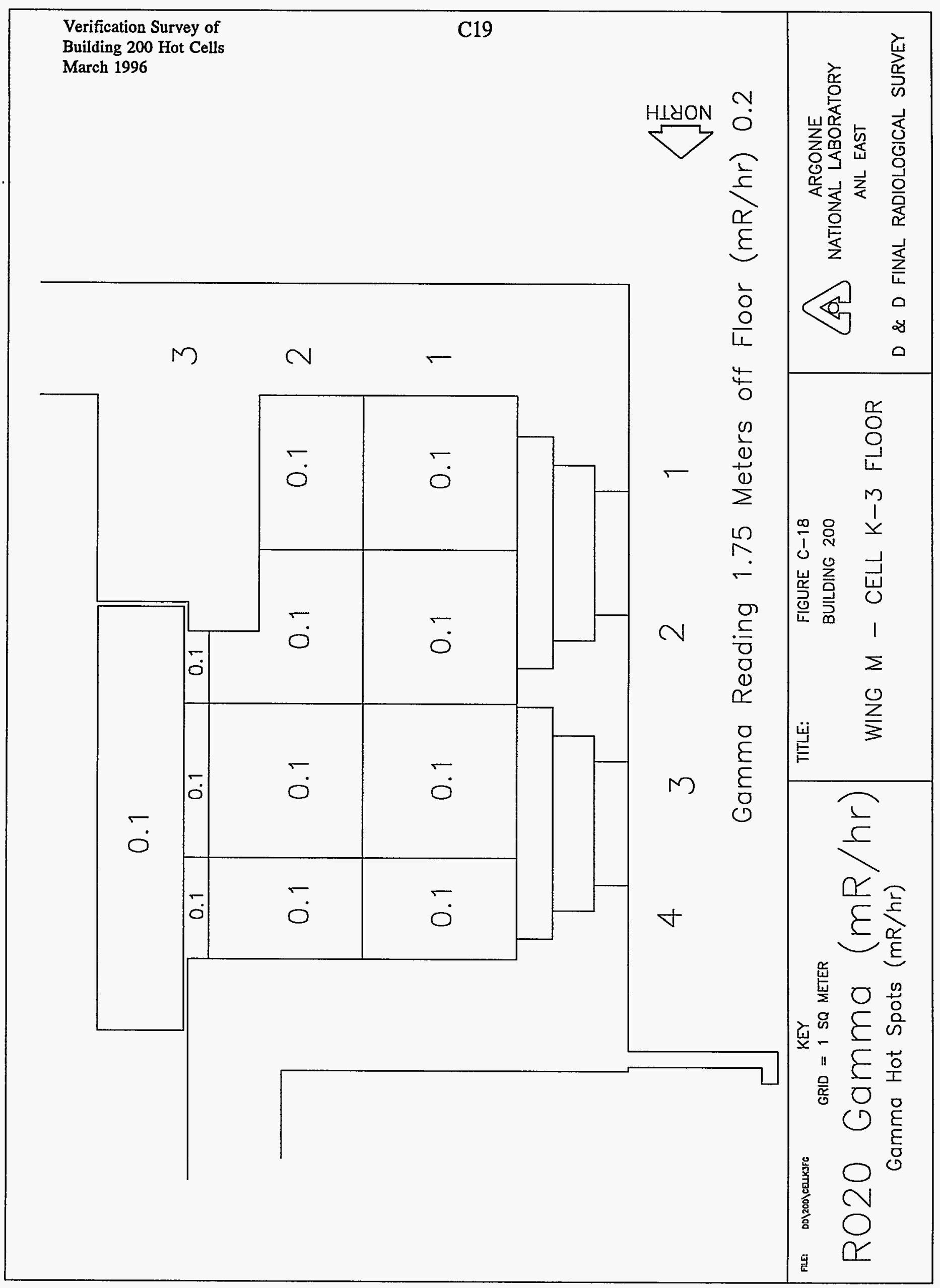




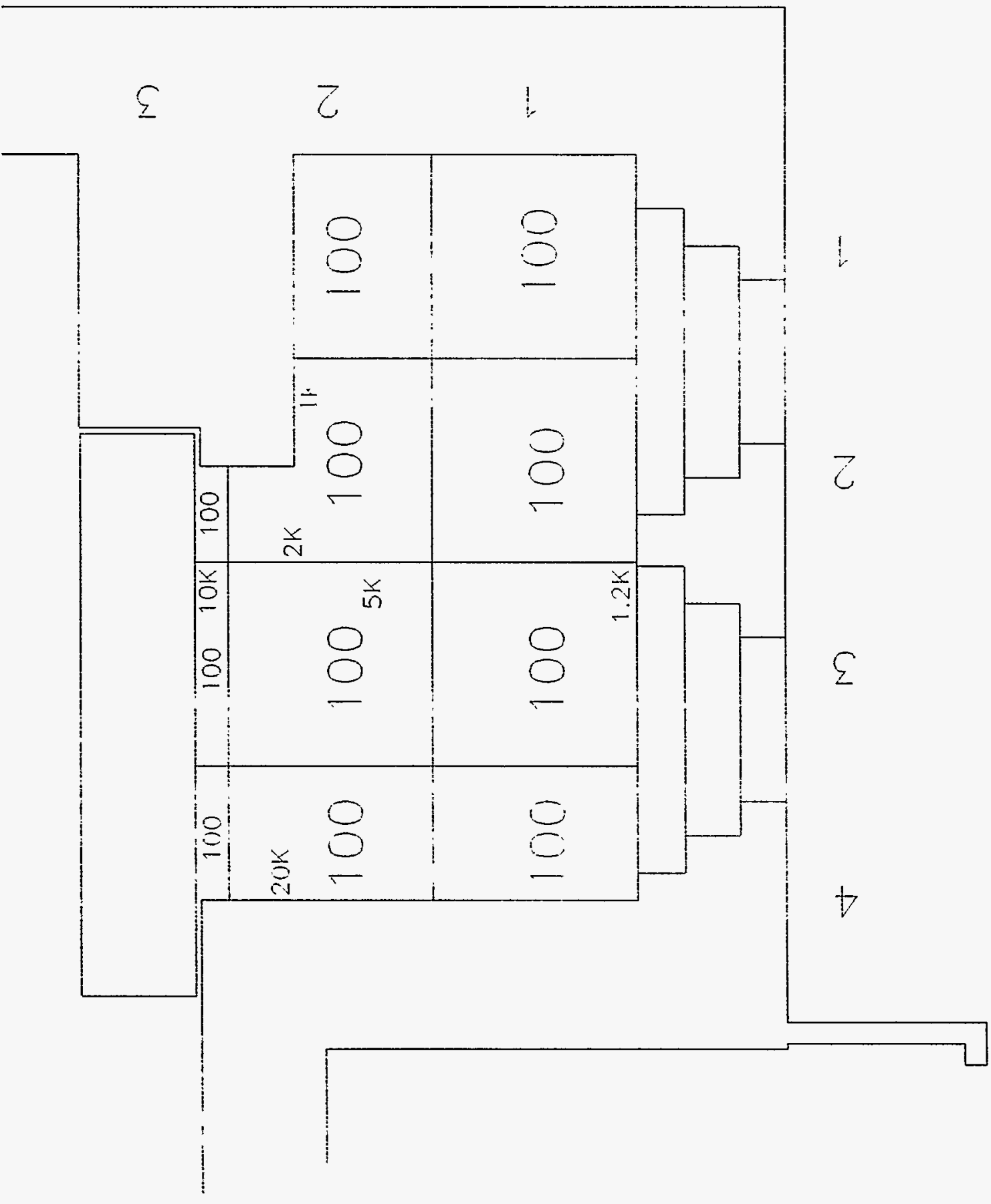

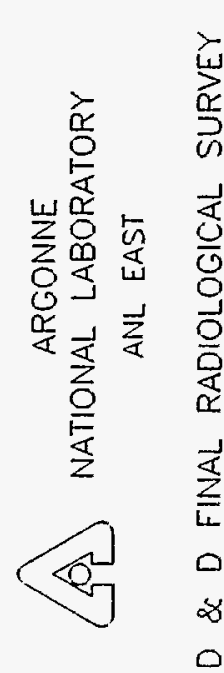

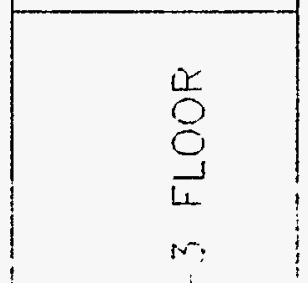

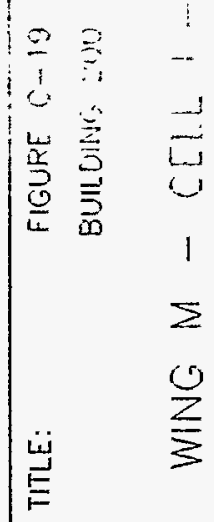

点 $\underbrace{\frac{\sigma}{\sigma} \stackrel{c r}{E}}_{\omega}$

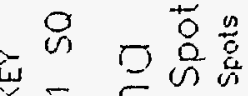

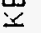

II 0 웅

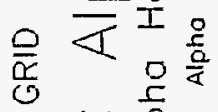
( ) $\frac{2}{4}$ T

$\square$ 


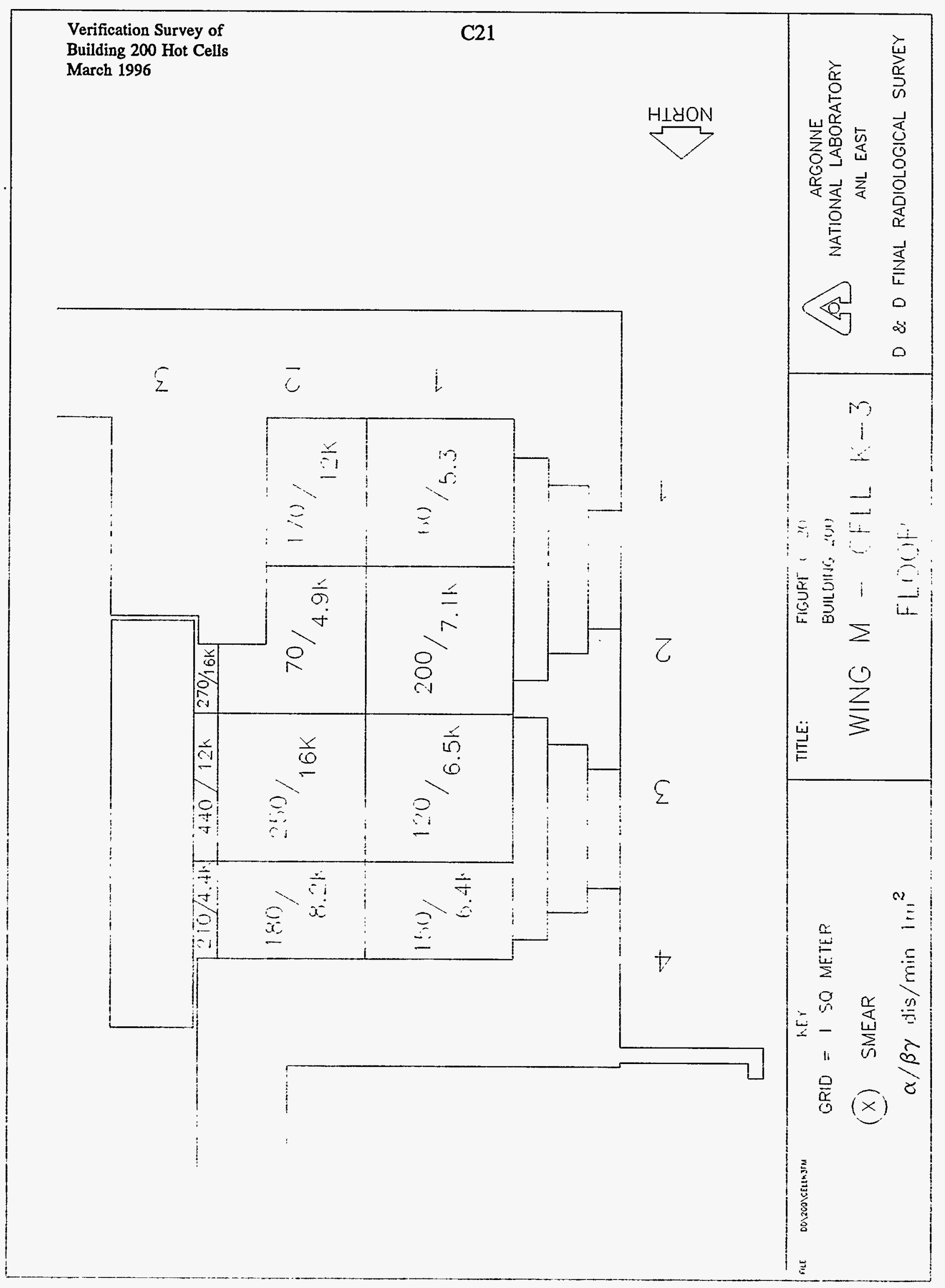




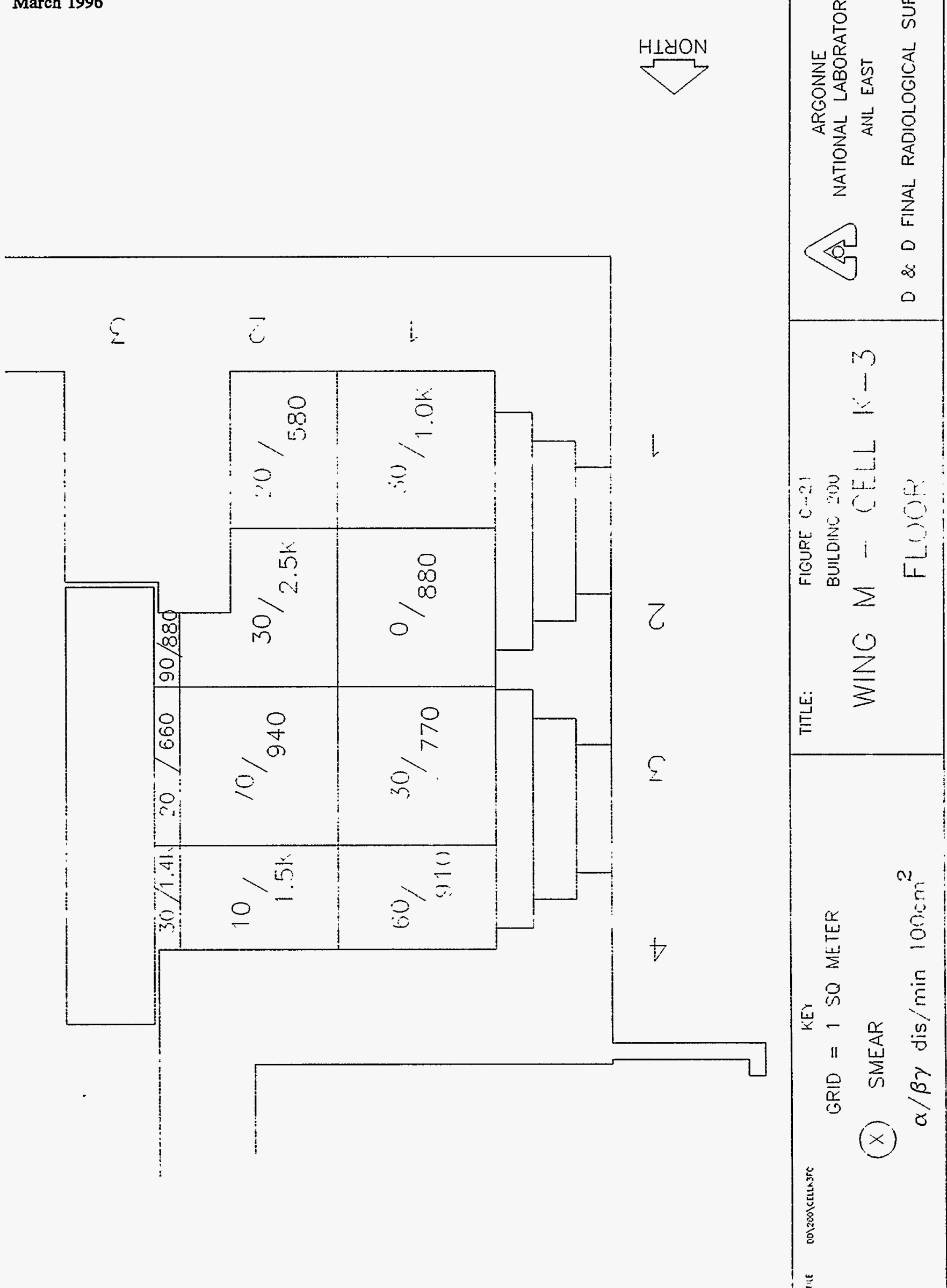


E

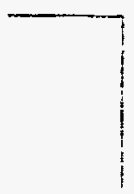

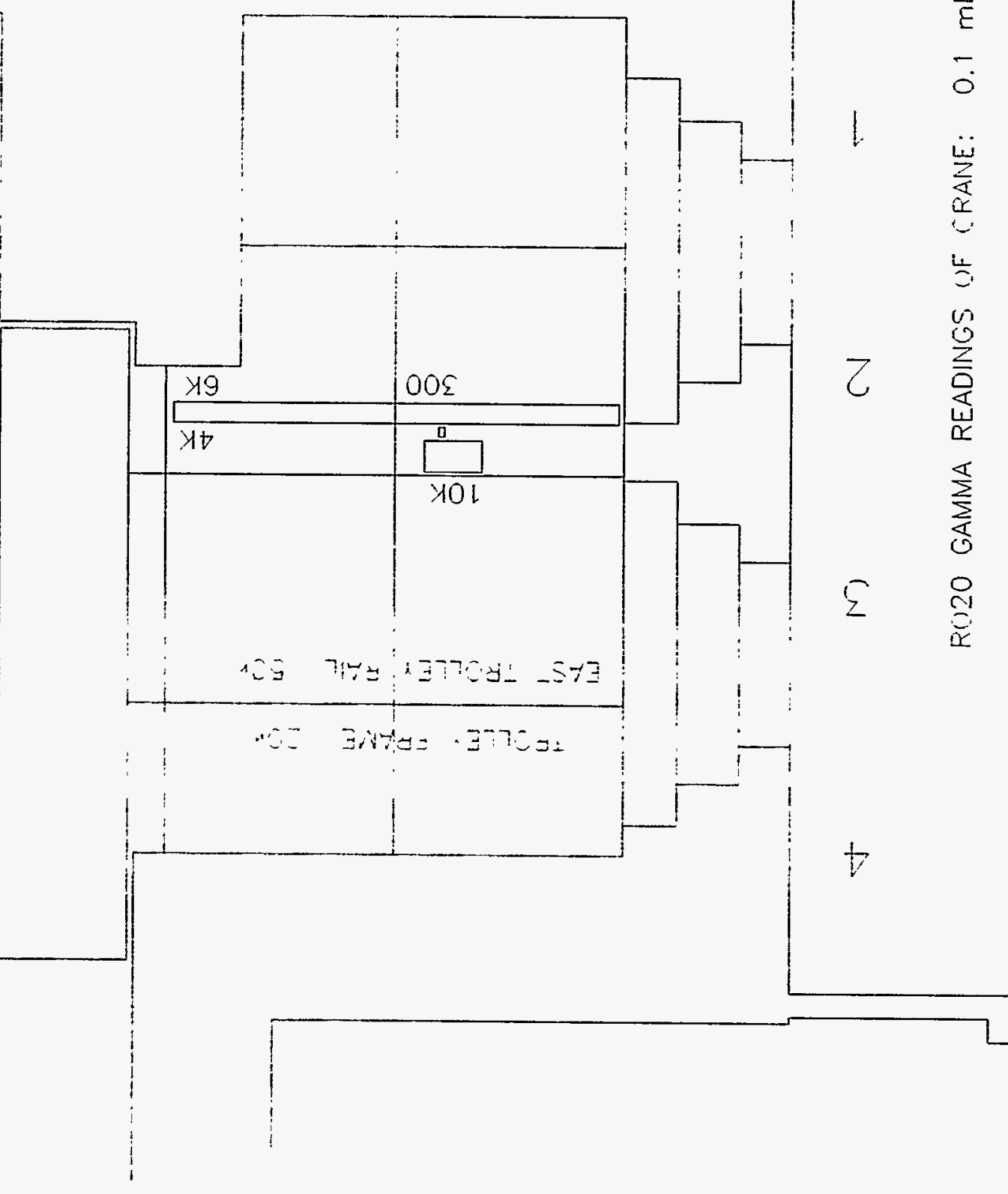

$-$

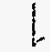




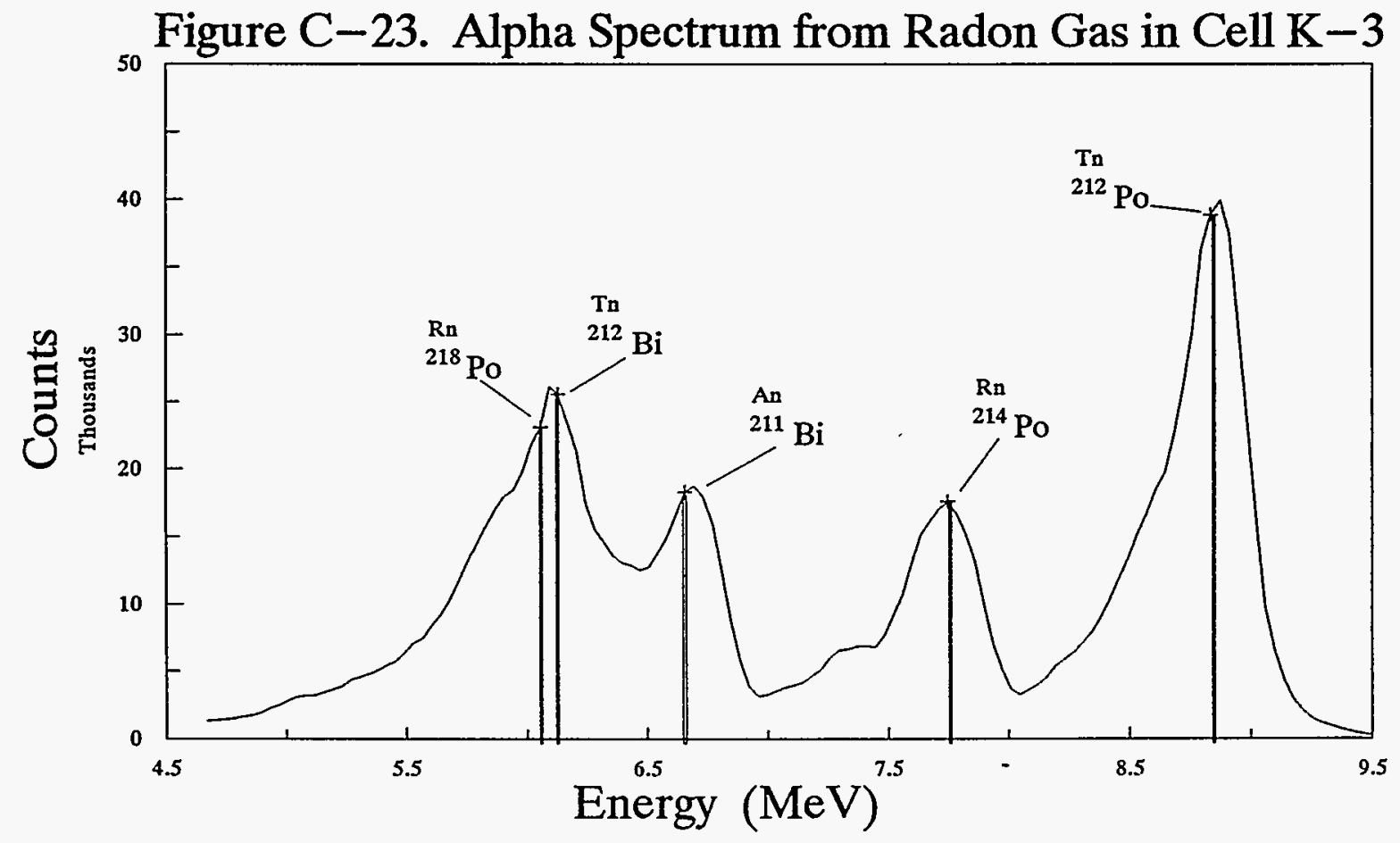

Figure ${ }_{80} \mathrm{C}-24$. Alpha Spectrum from Radon Gas in Cell $\mathrm{K}-1$

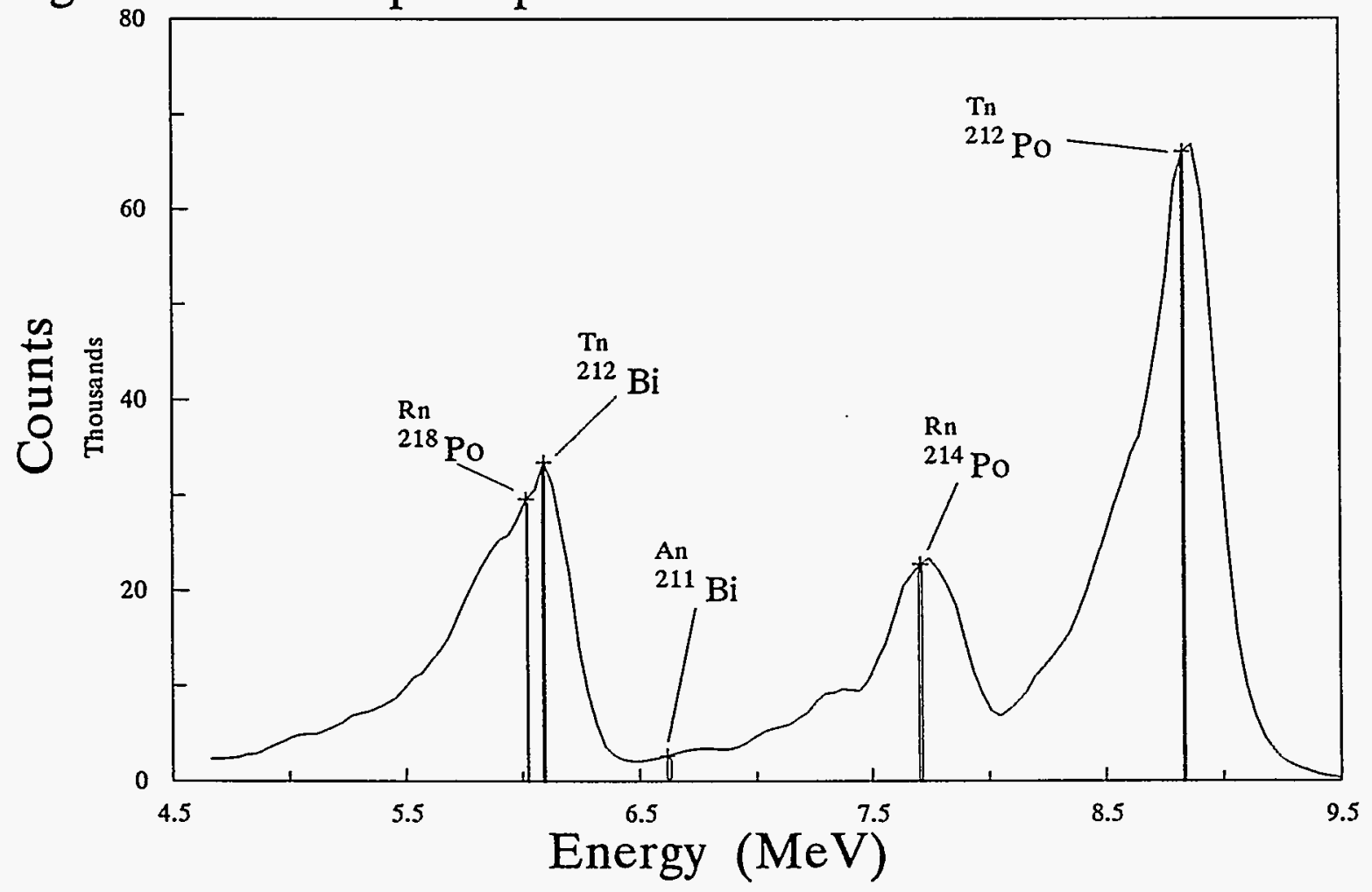




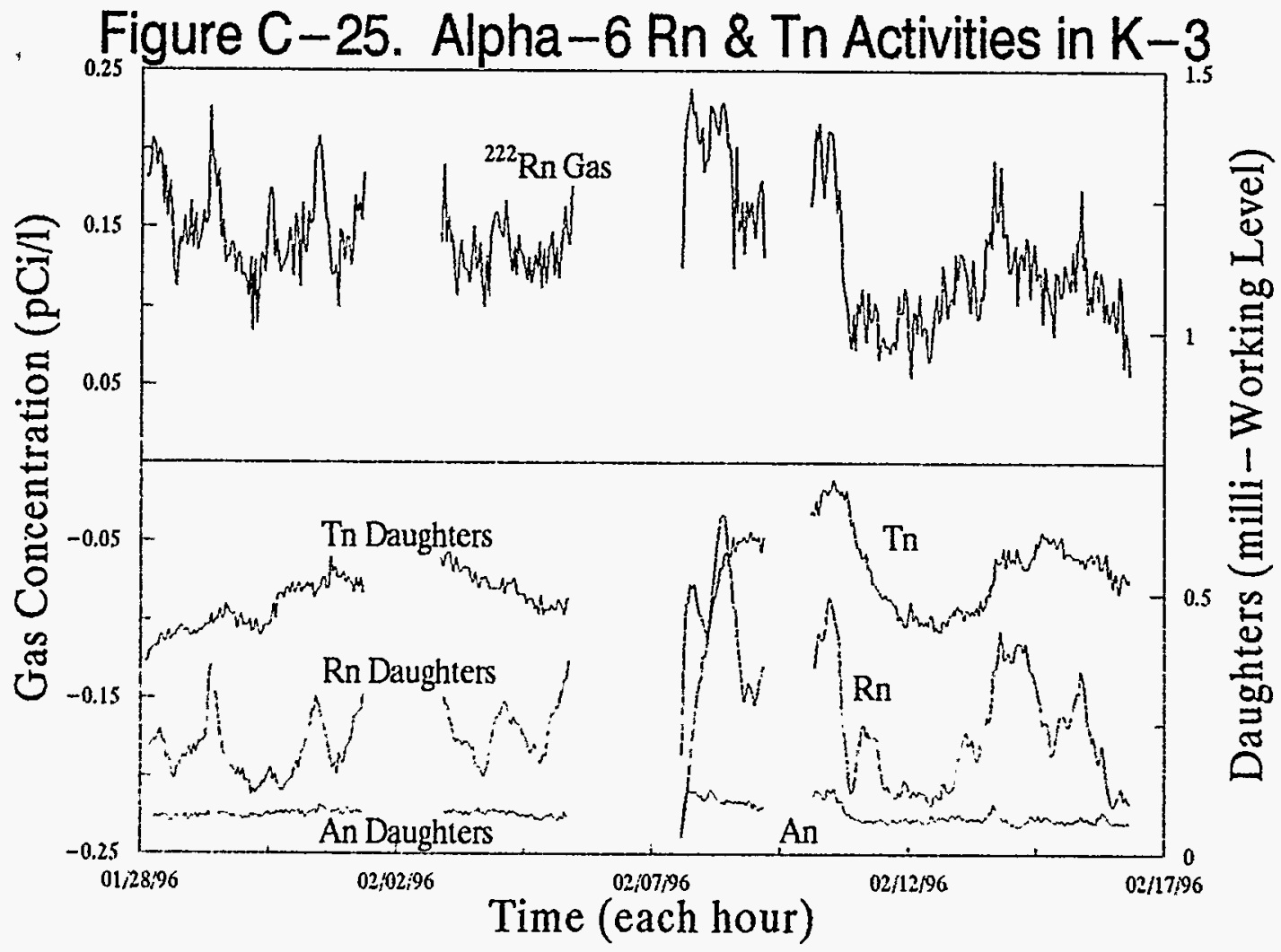

Figure C-26. Decay of Daughter Products

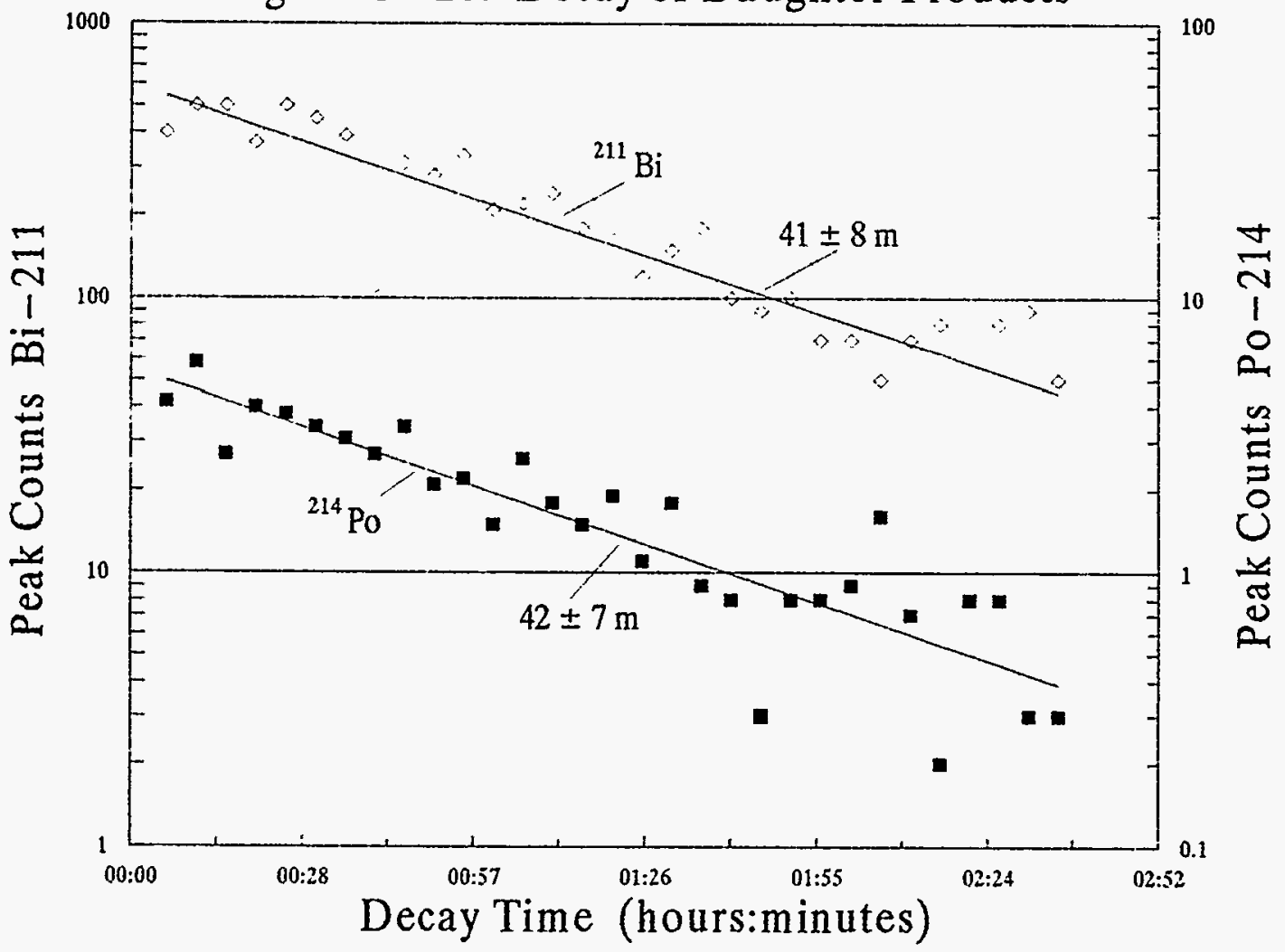



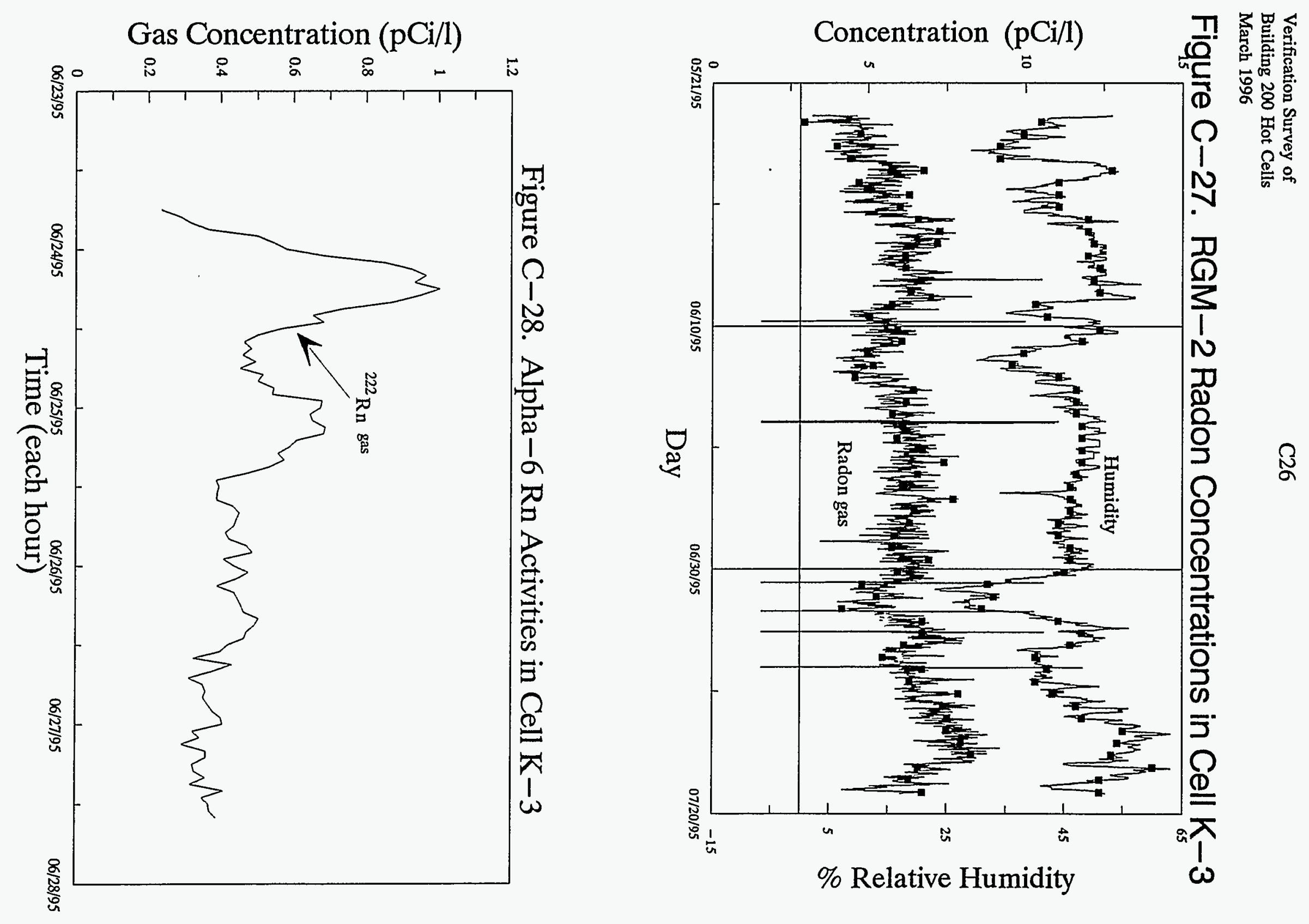
Verification Survey of

Building 200 Hot Cells

March 1996

APPENDIX D Cell M-3 Figures 


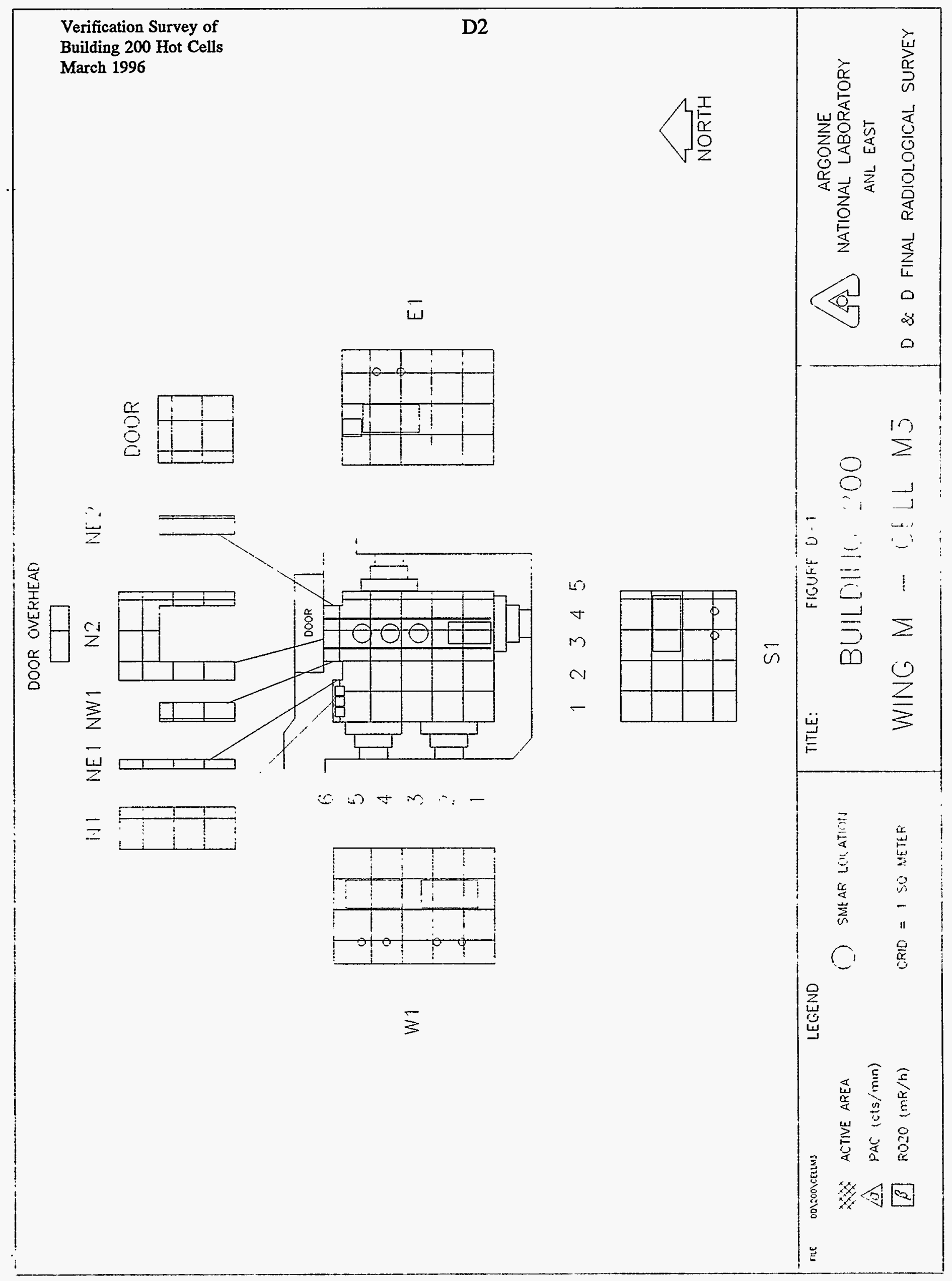




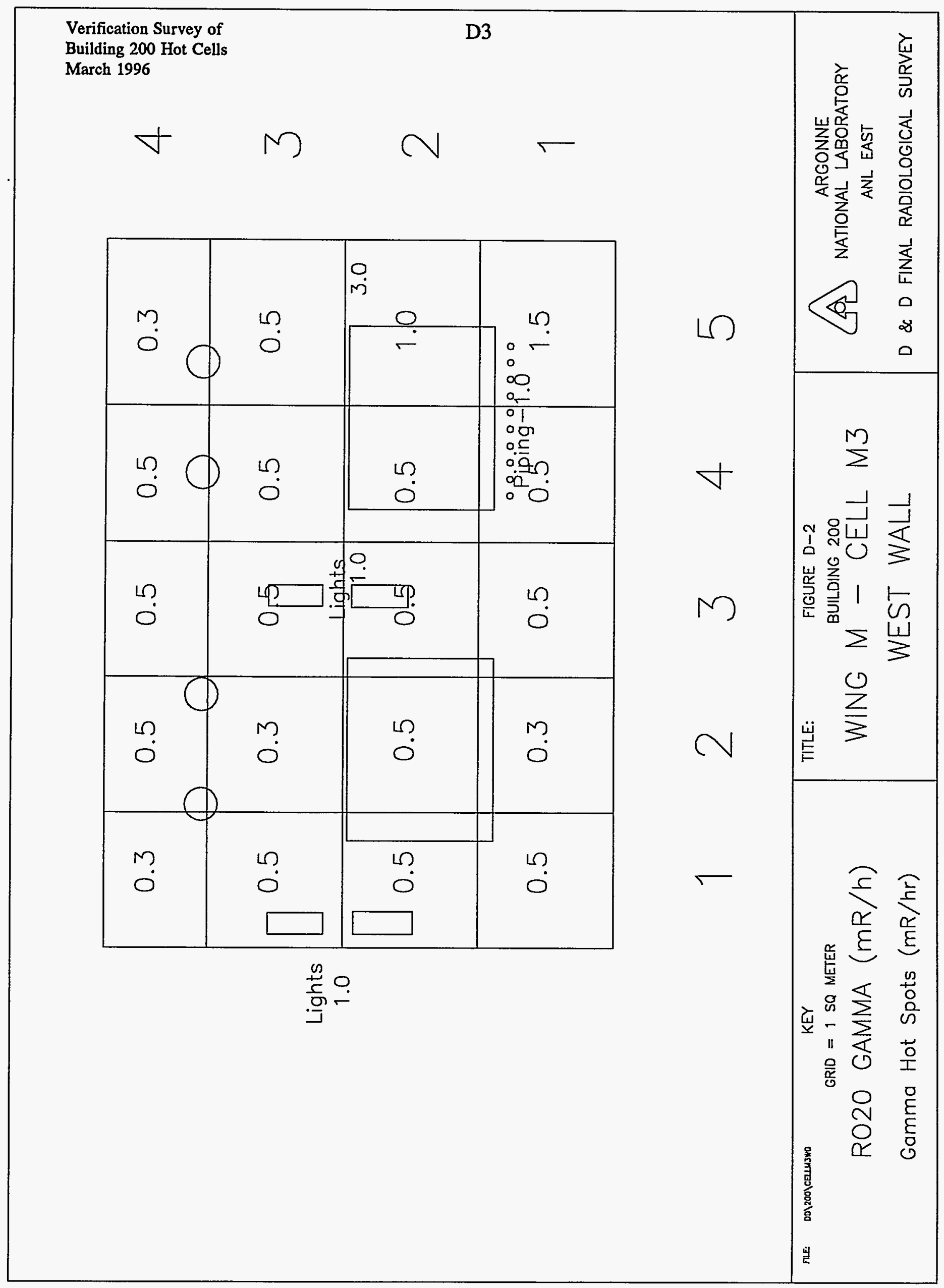




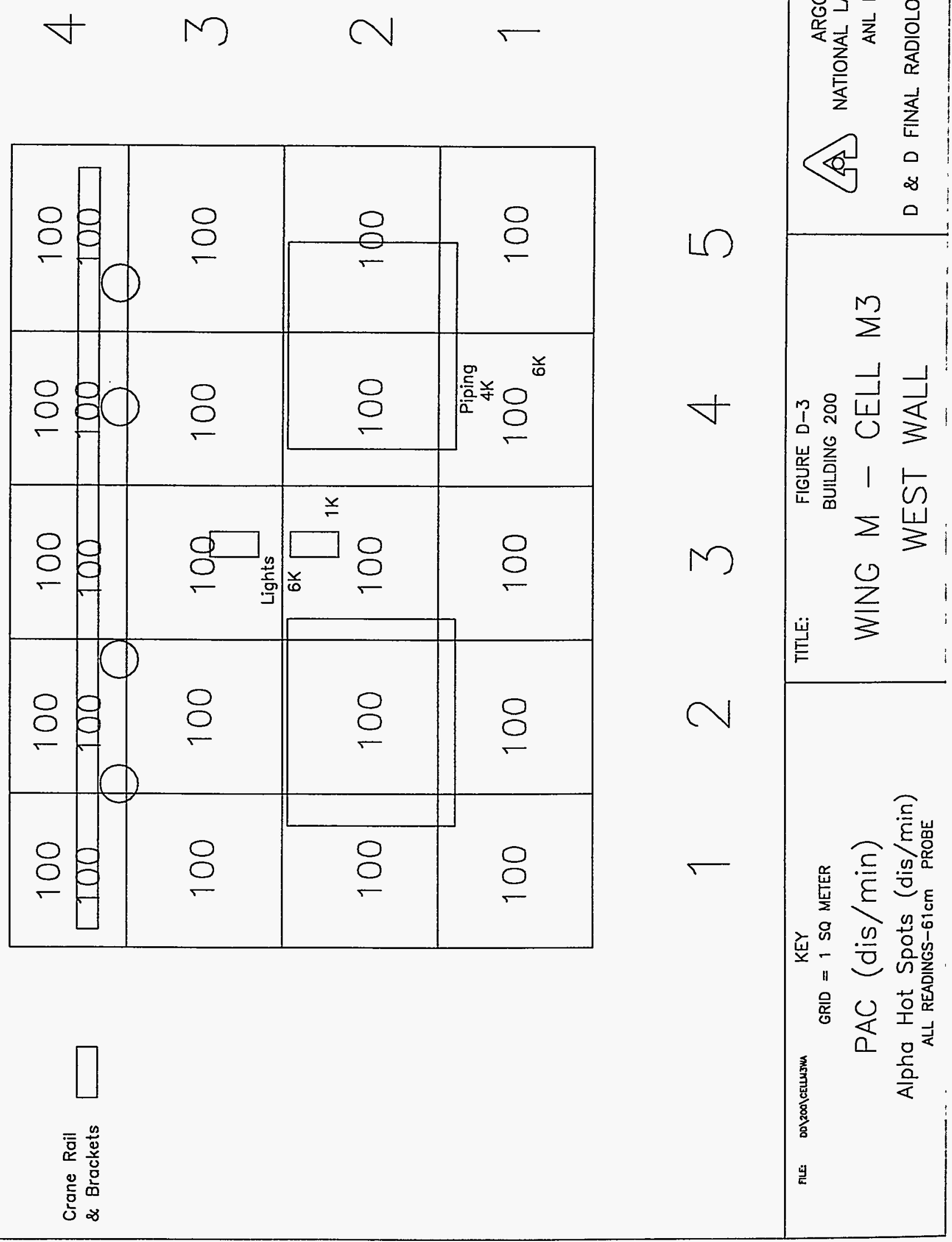




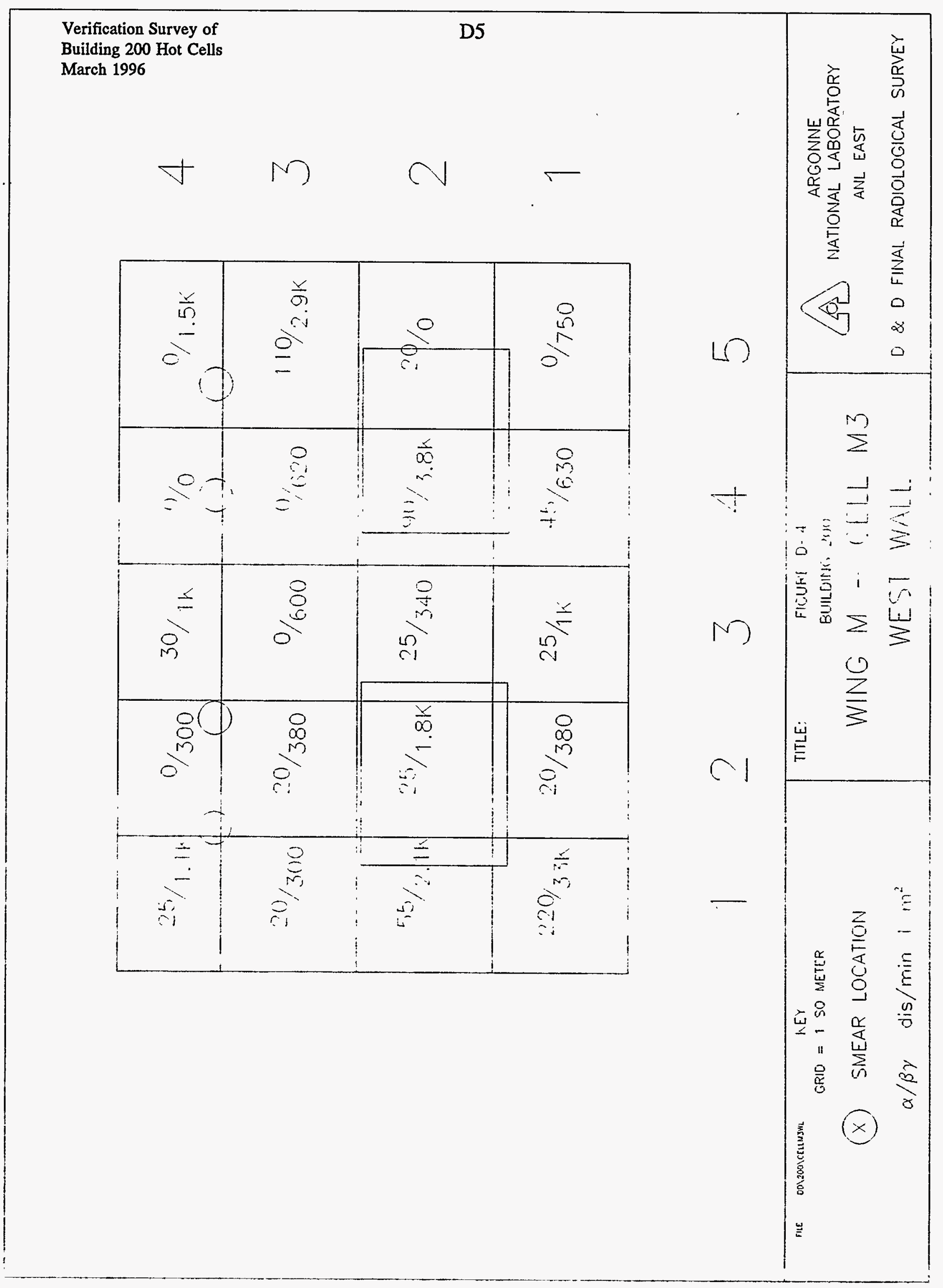




\section{Verification Survey of}

Building 200 Hot Cells

March 1996

$\nabla M$

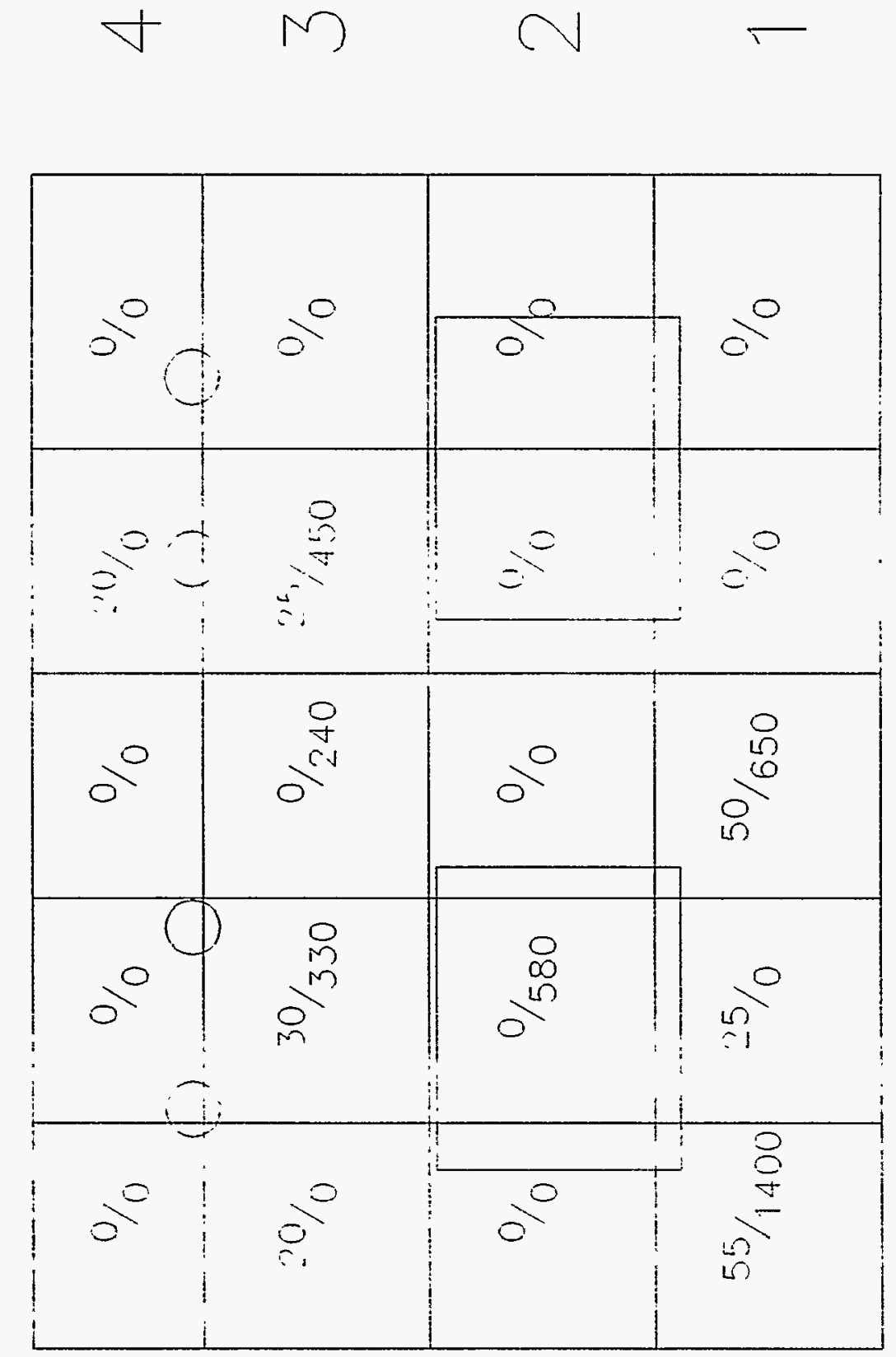

D6

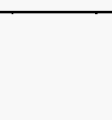


Verification Survey of

Building 200 Hot Cells

March 1996

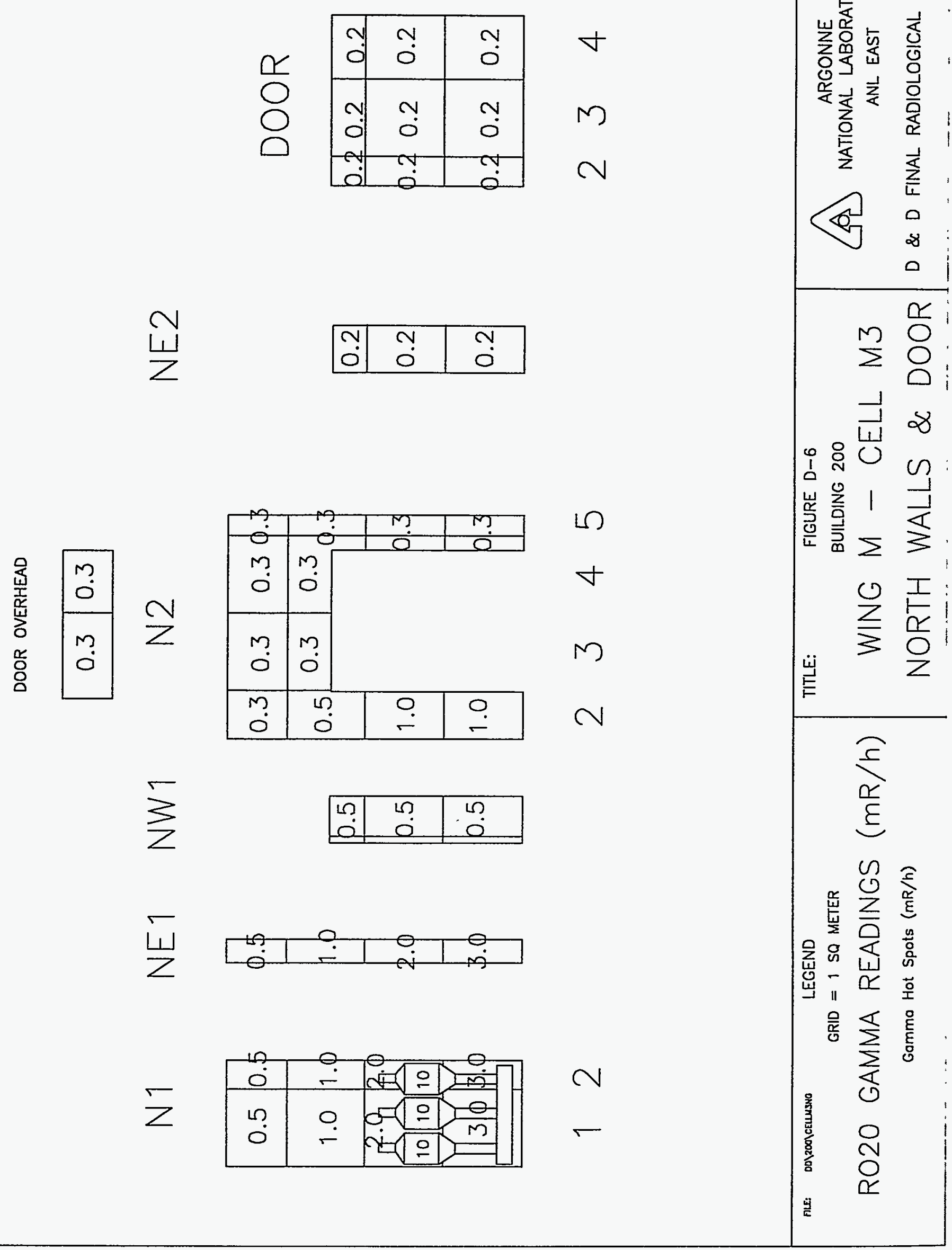




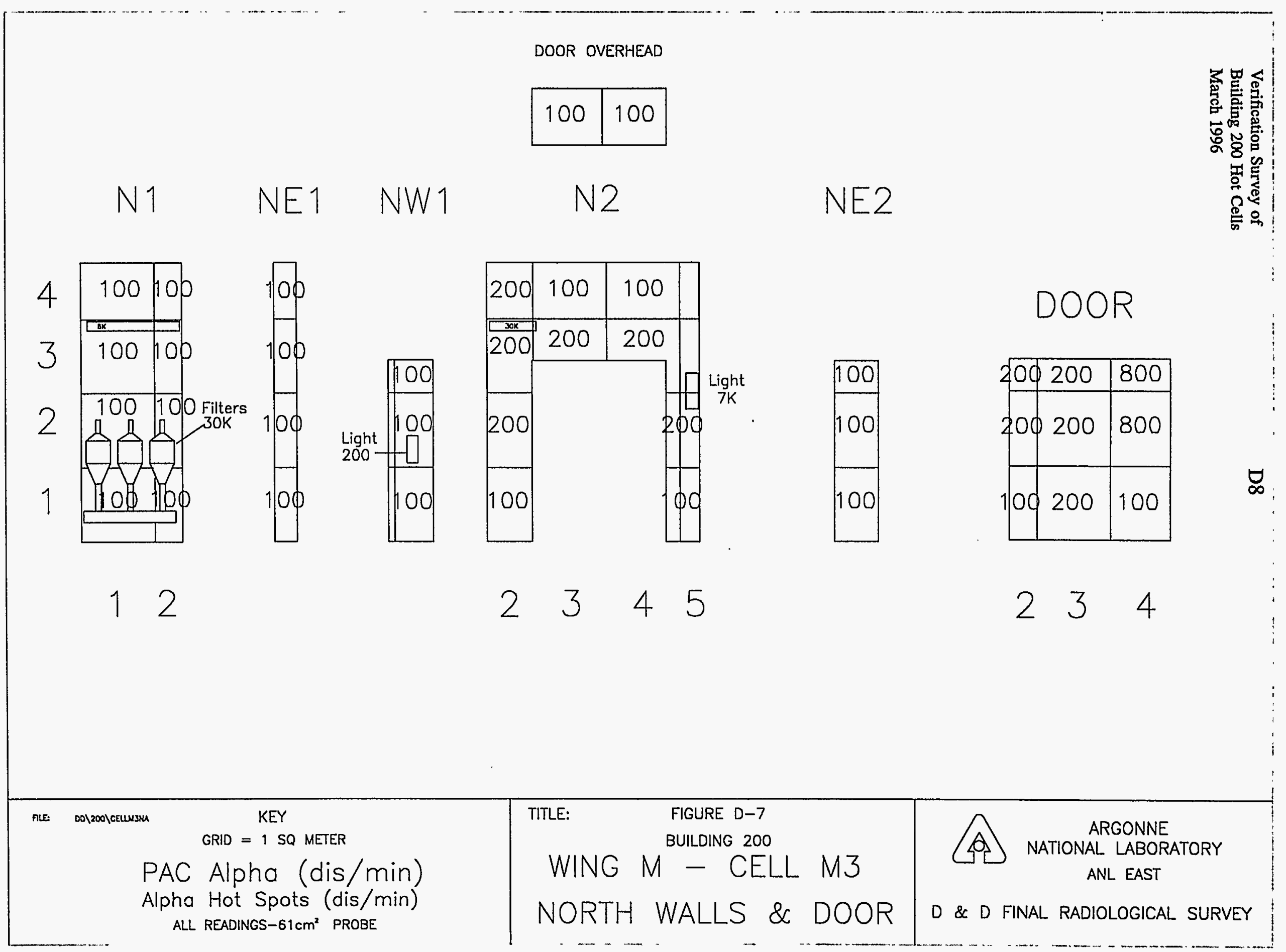




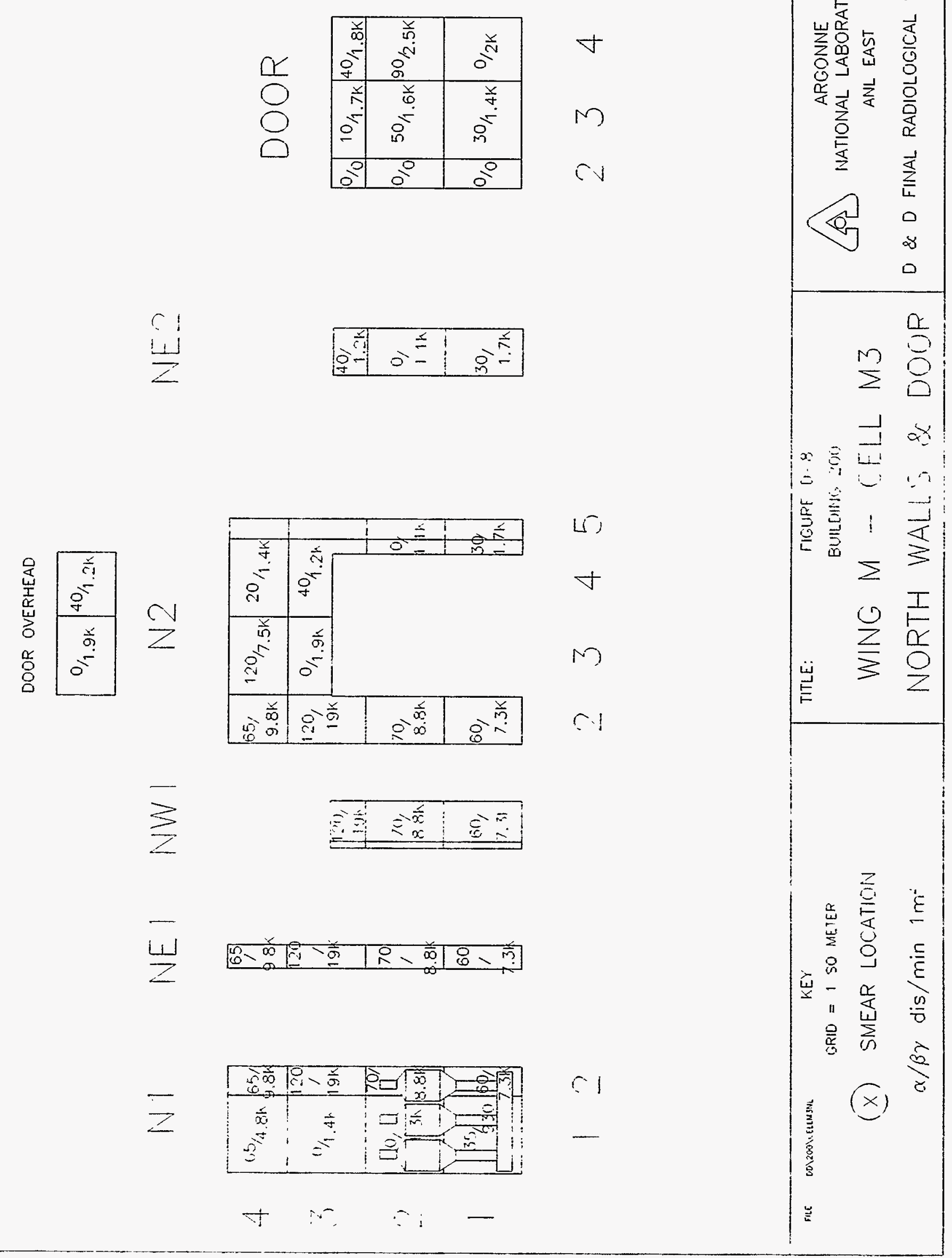




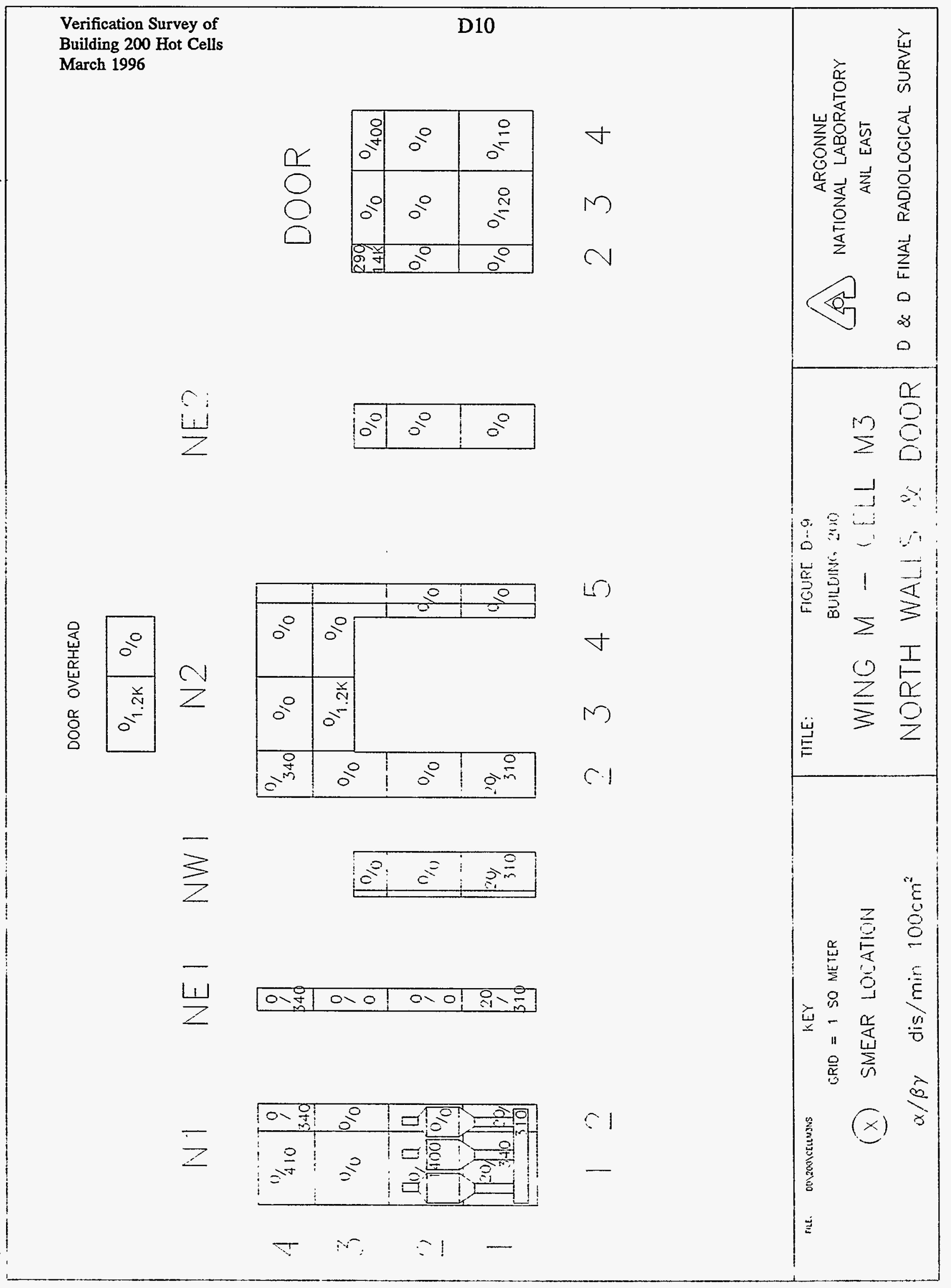




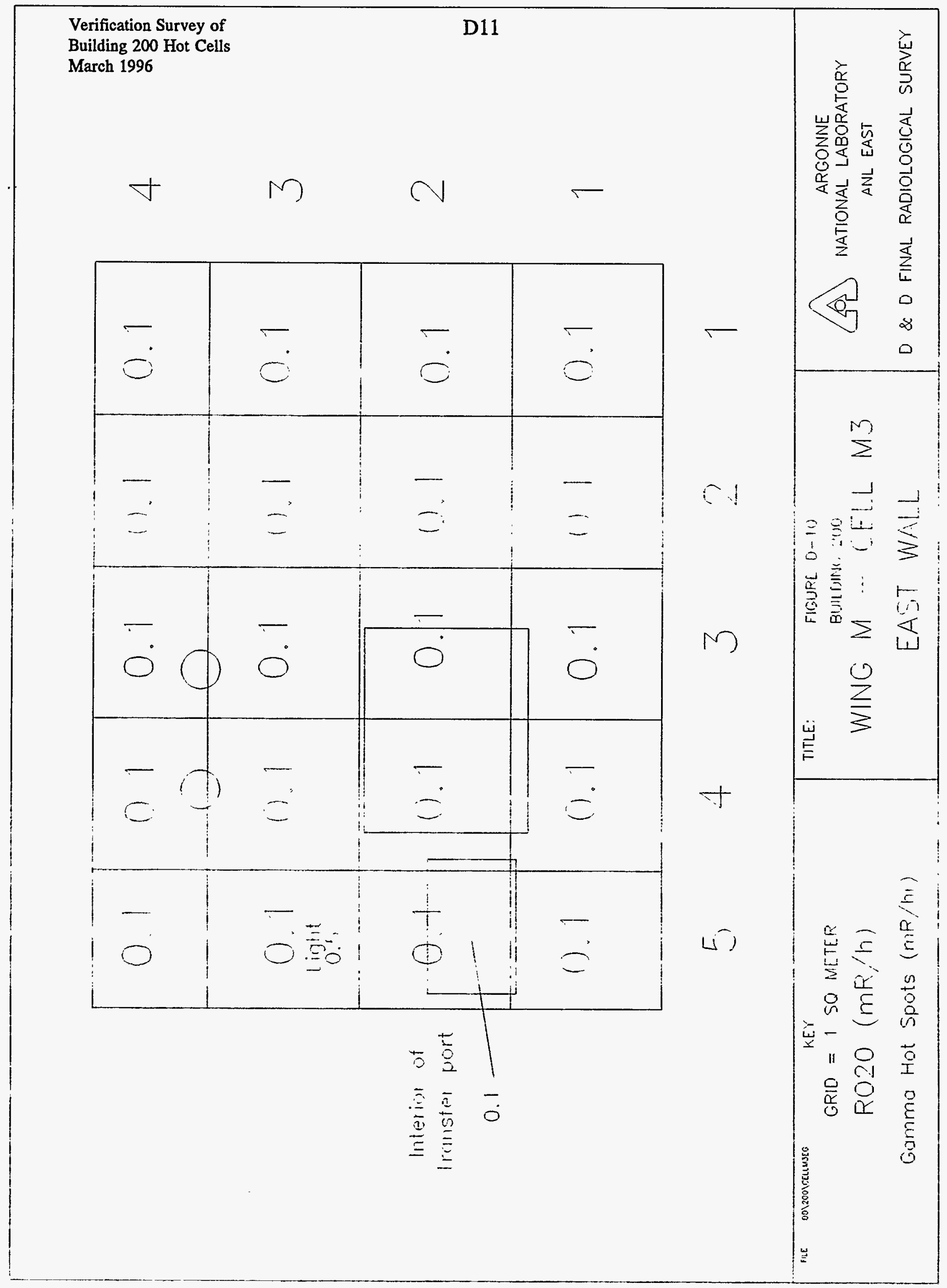




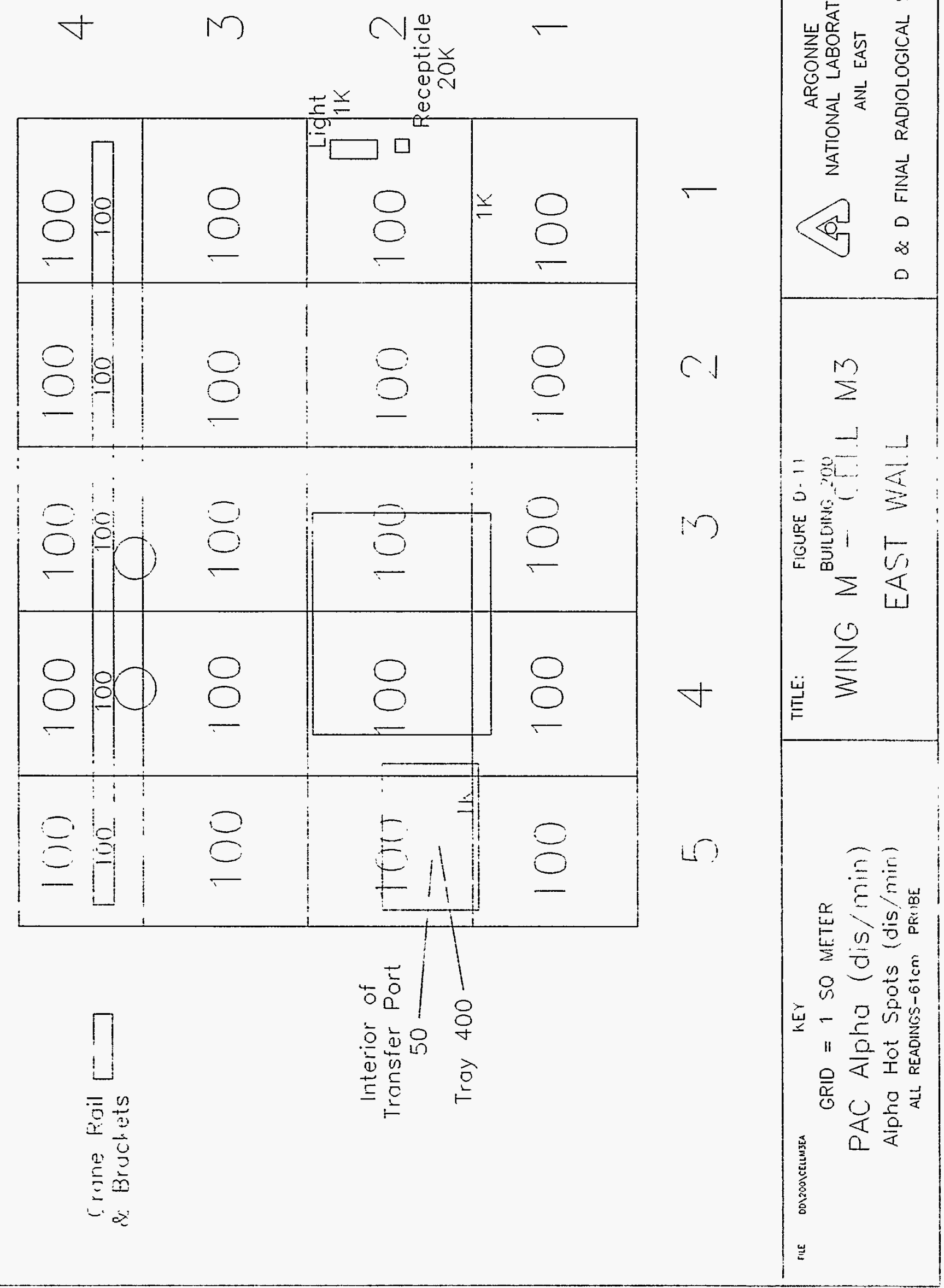




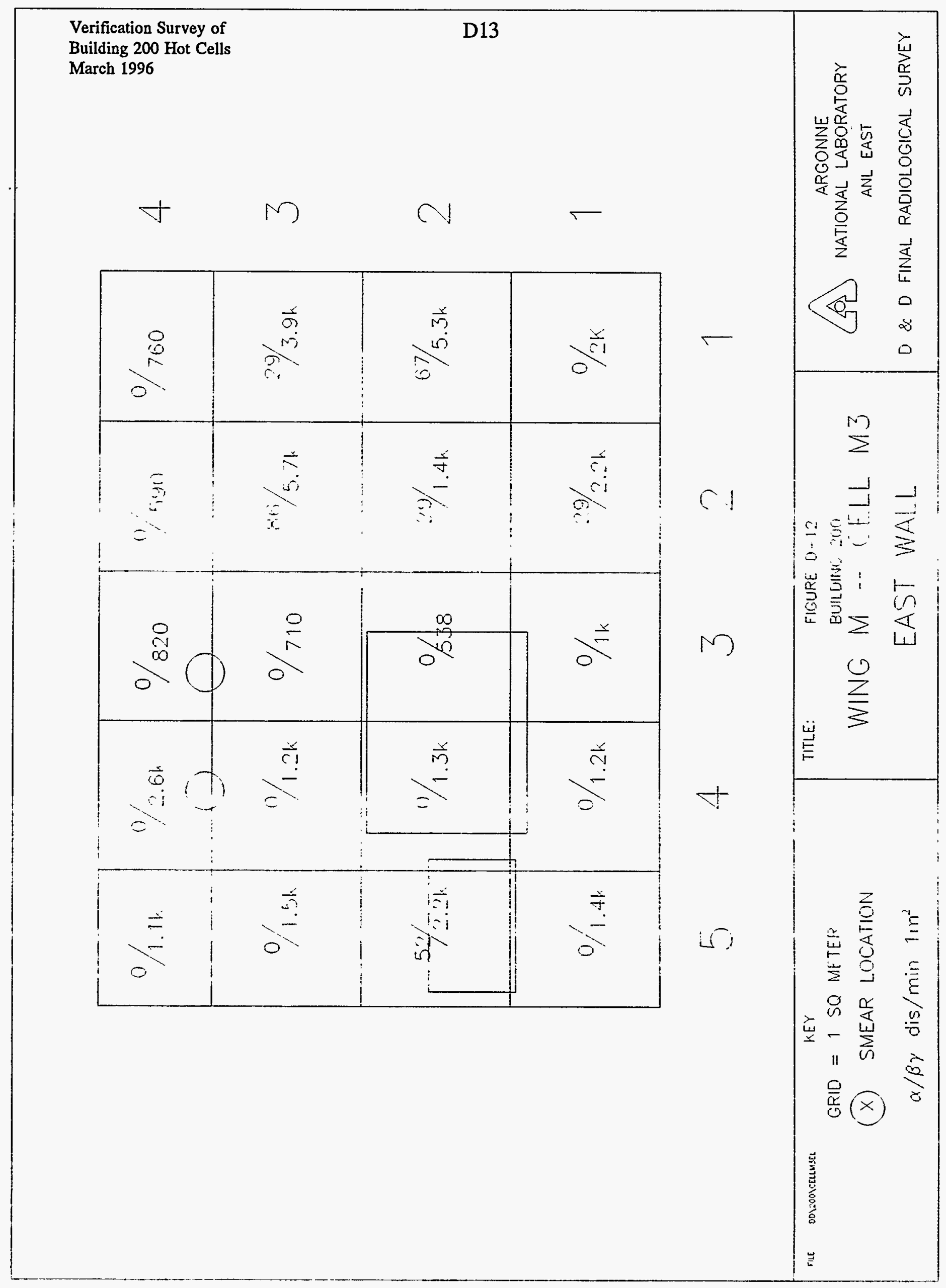




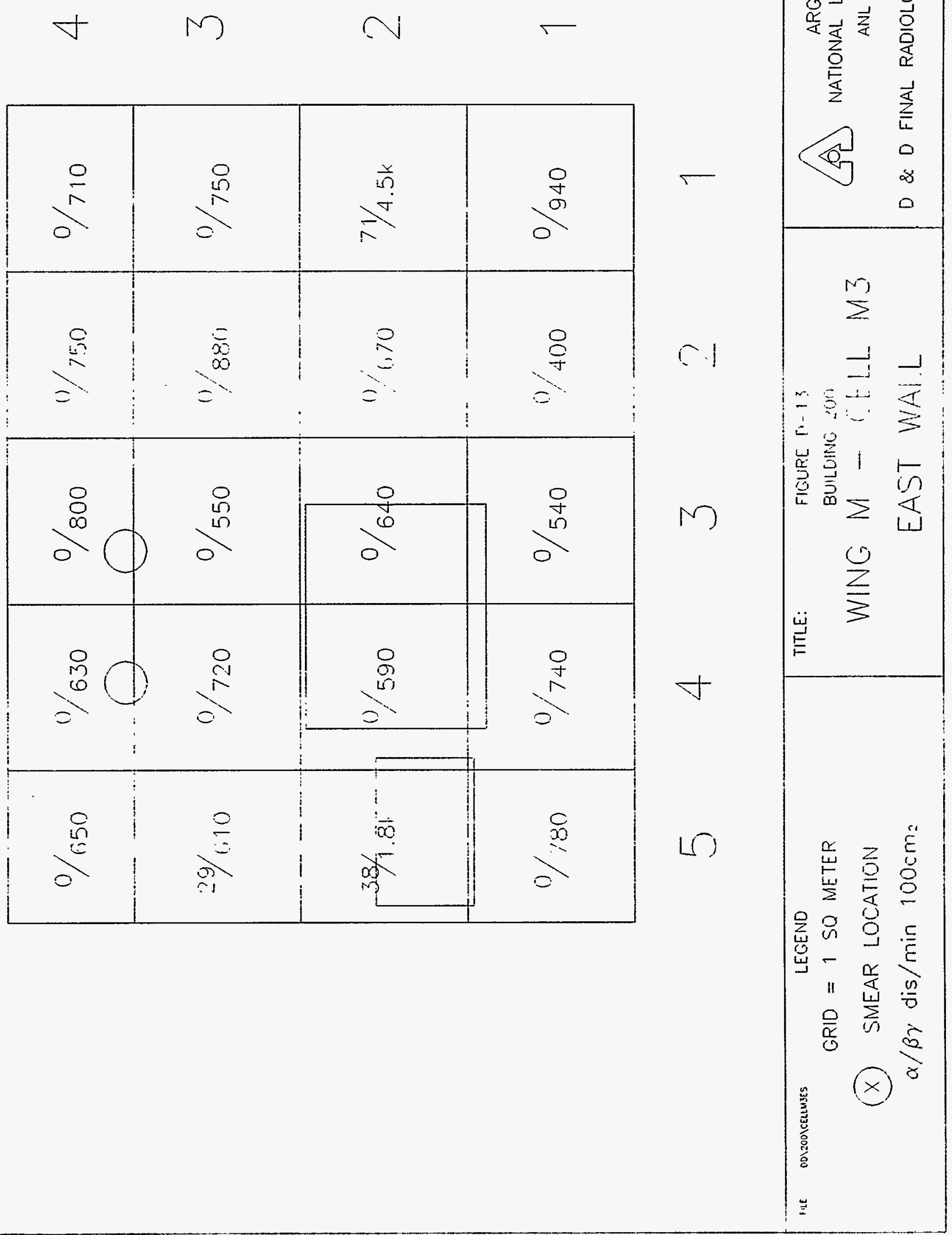




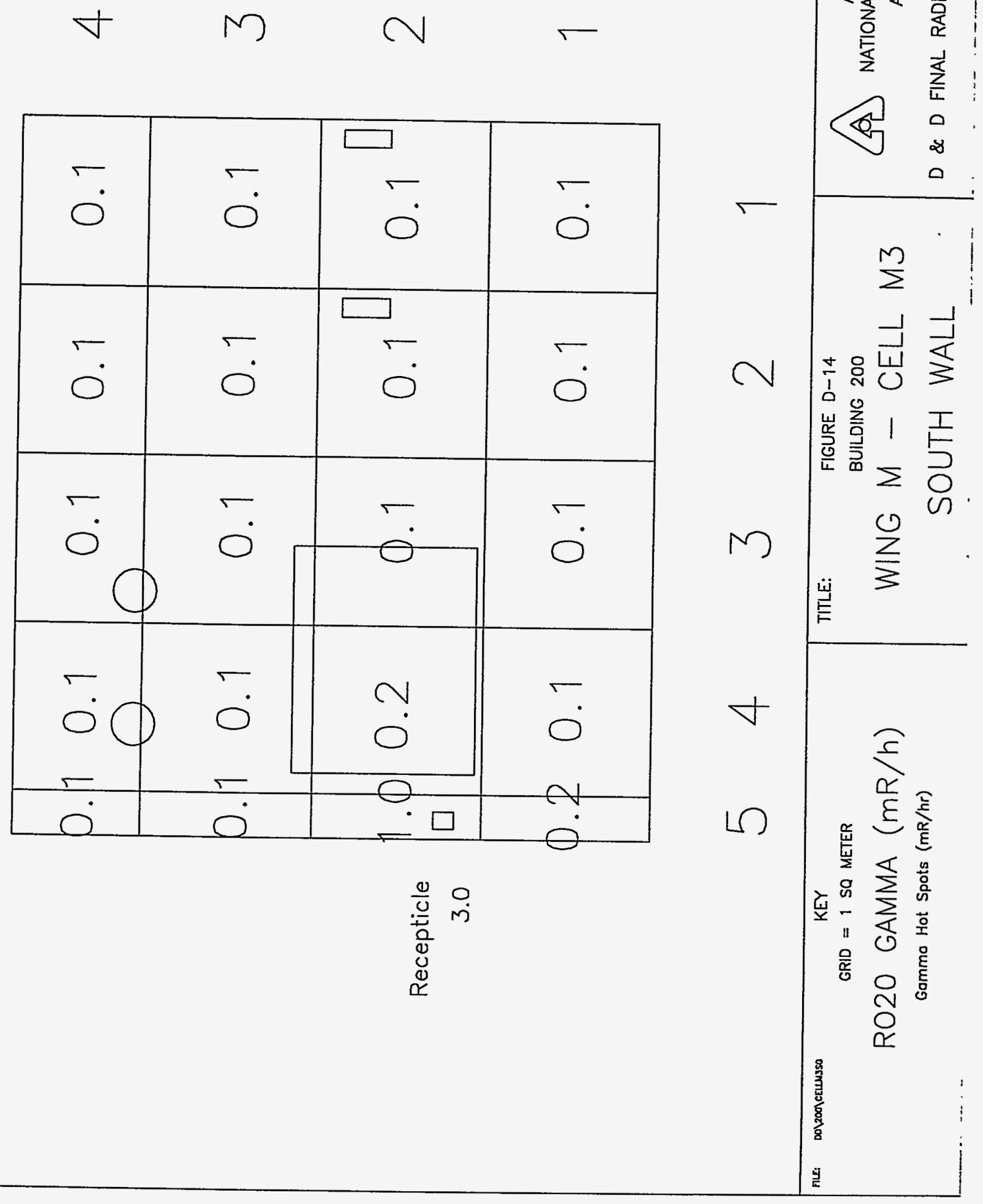




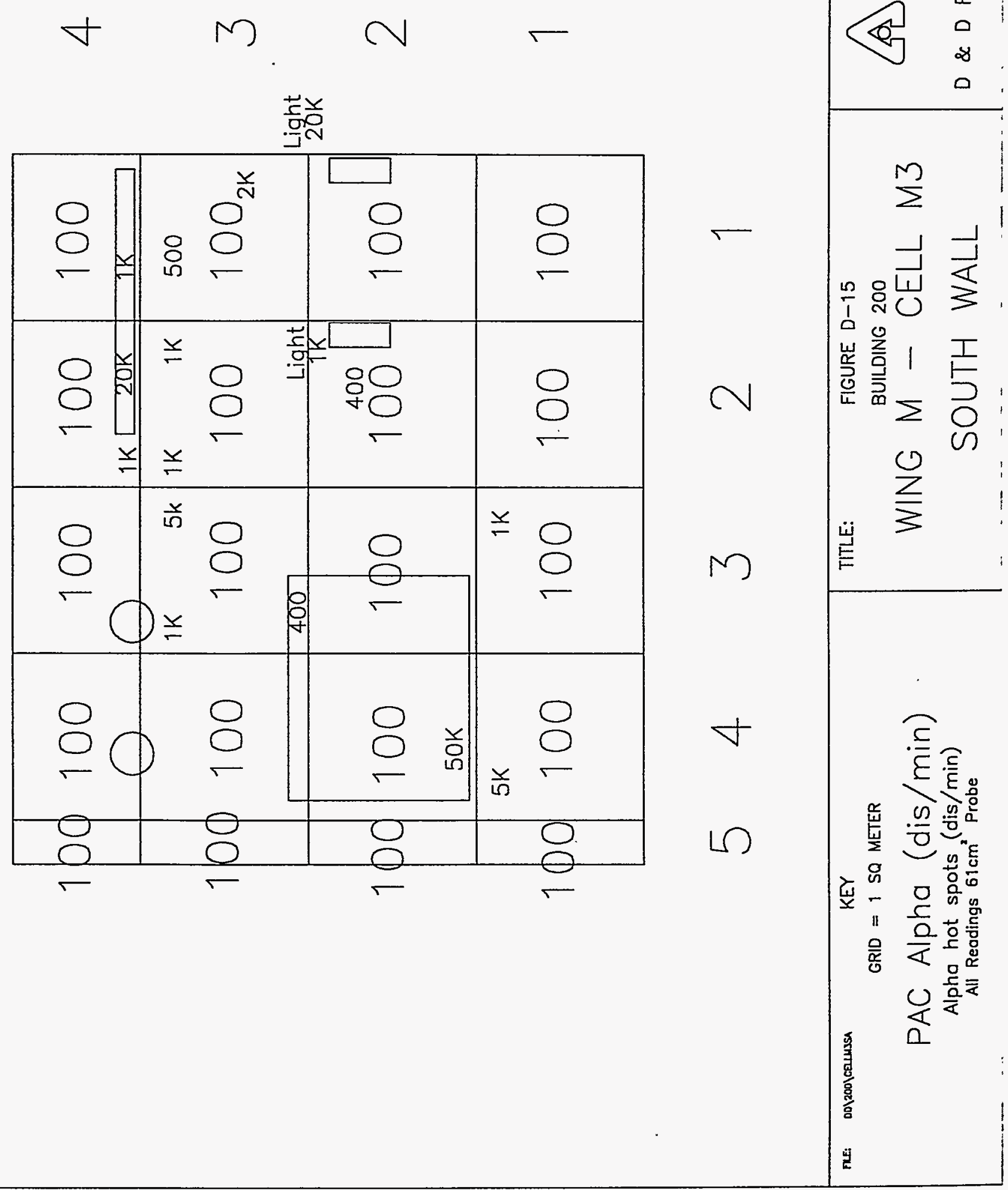



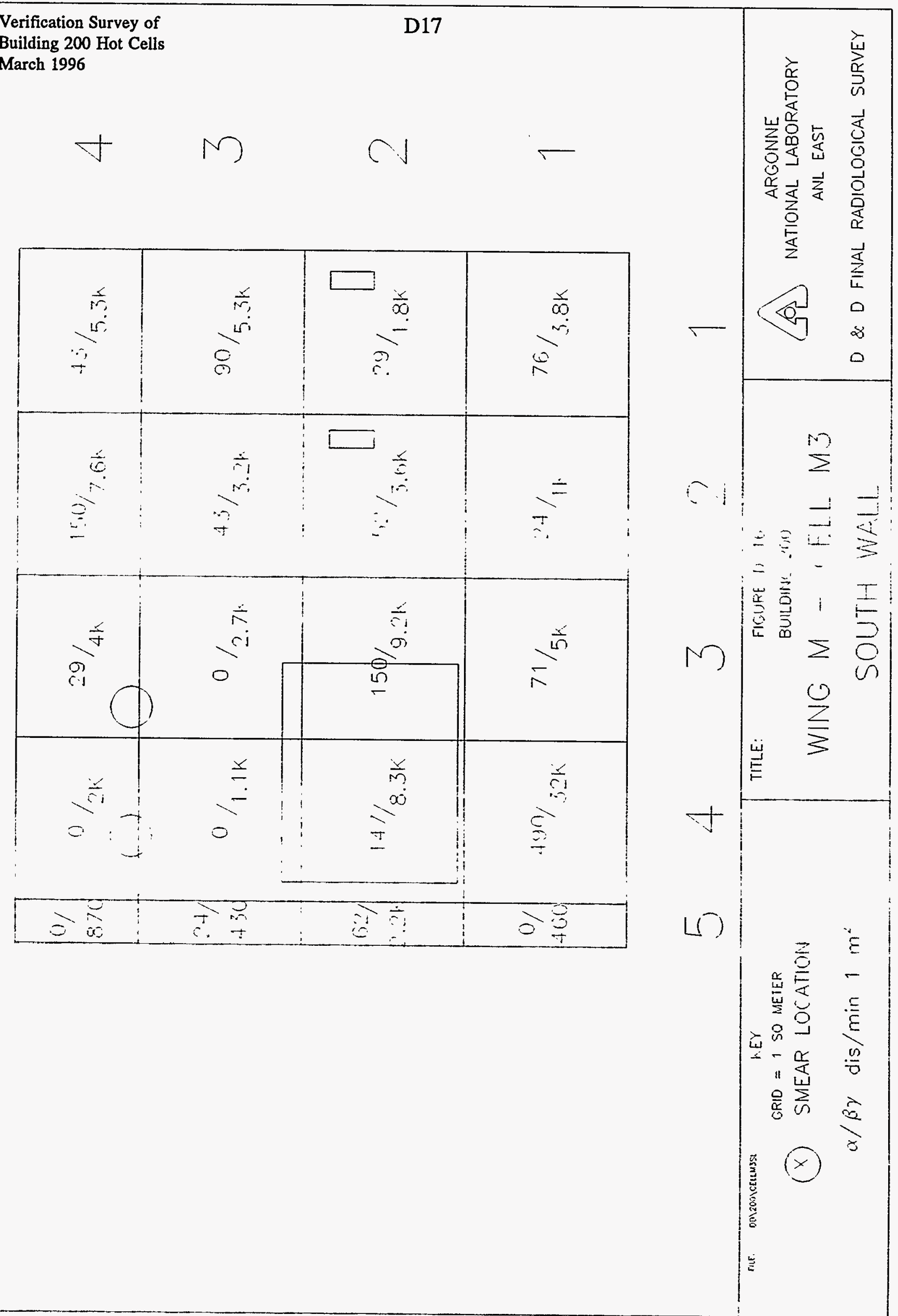


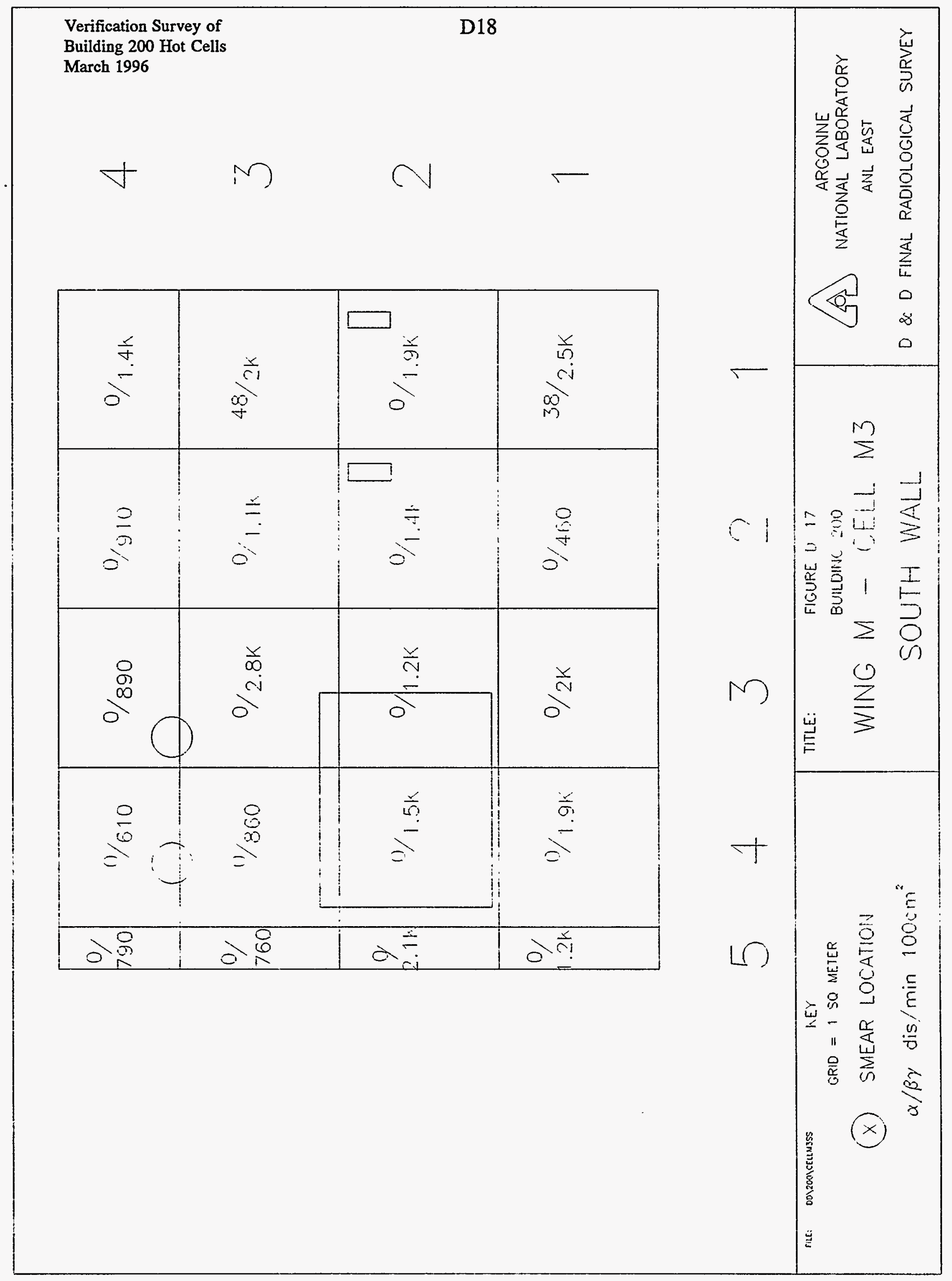




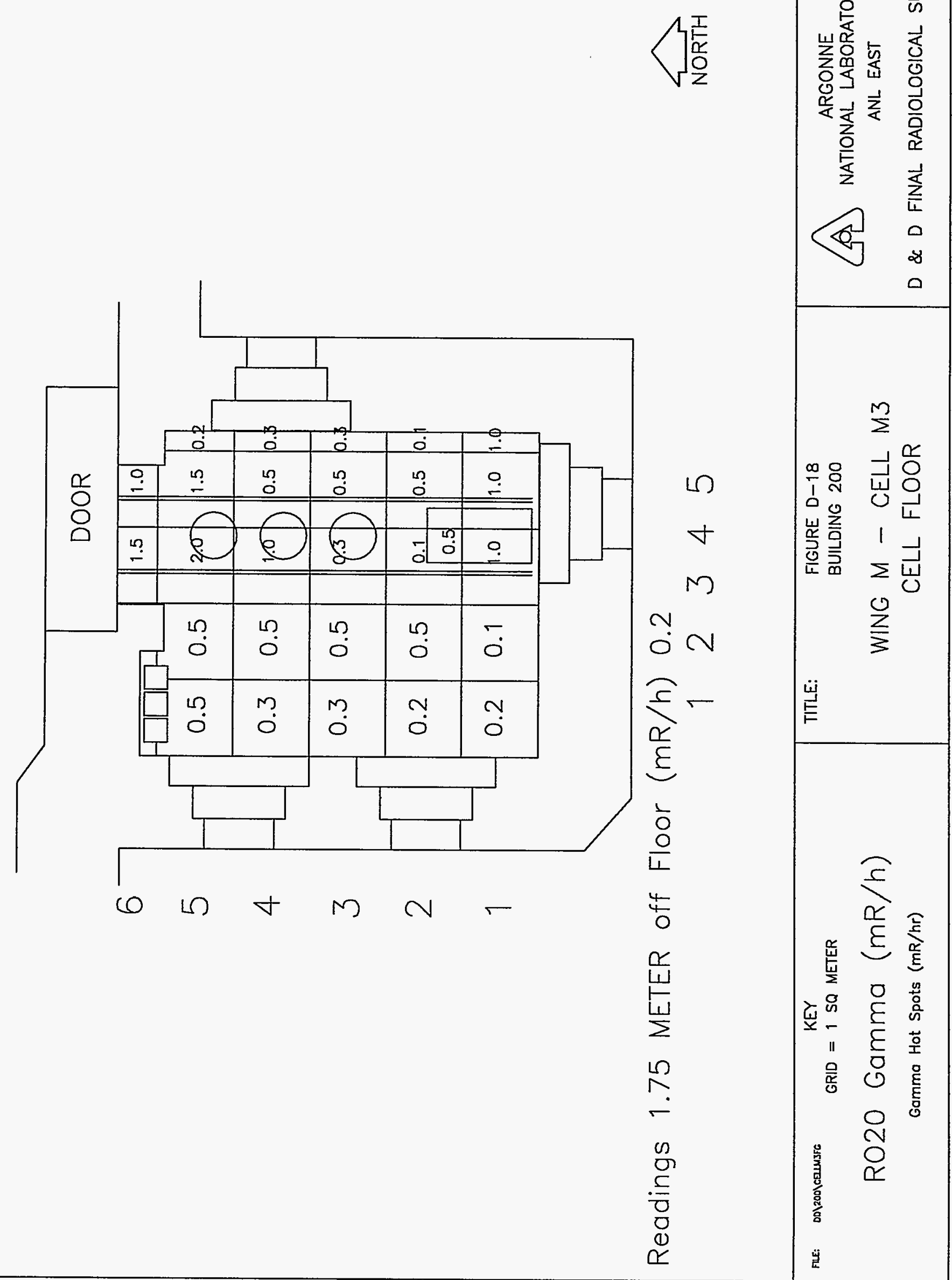

$\int^{I}$

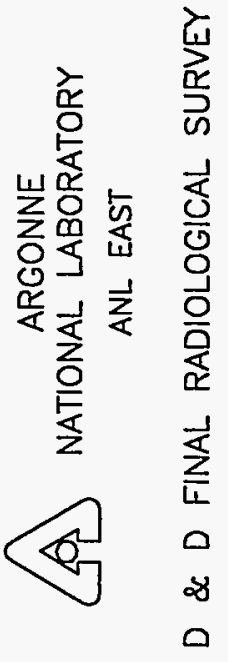




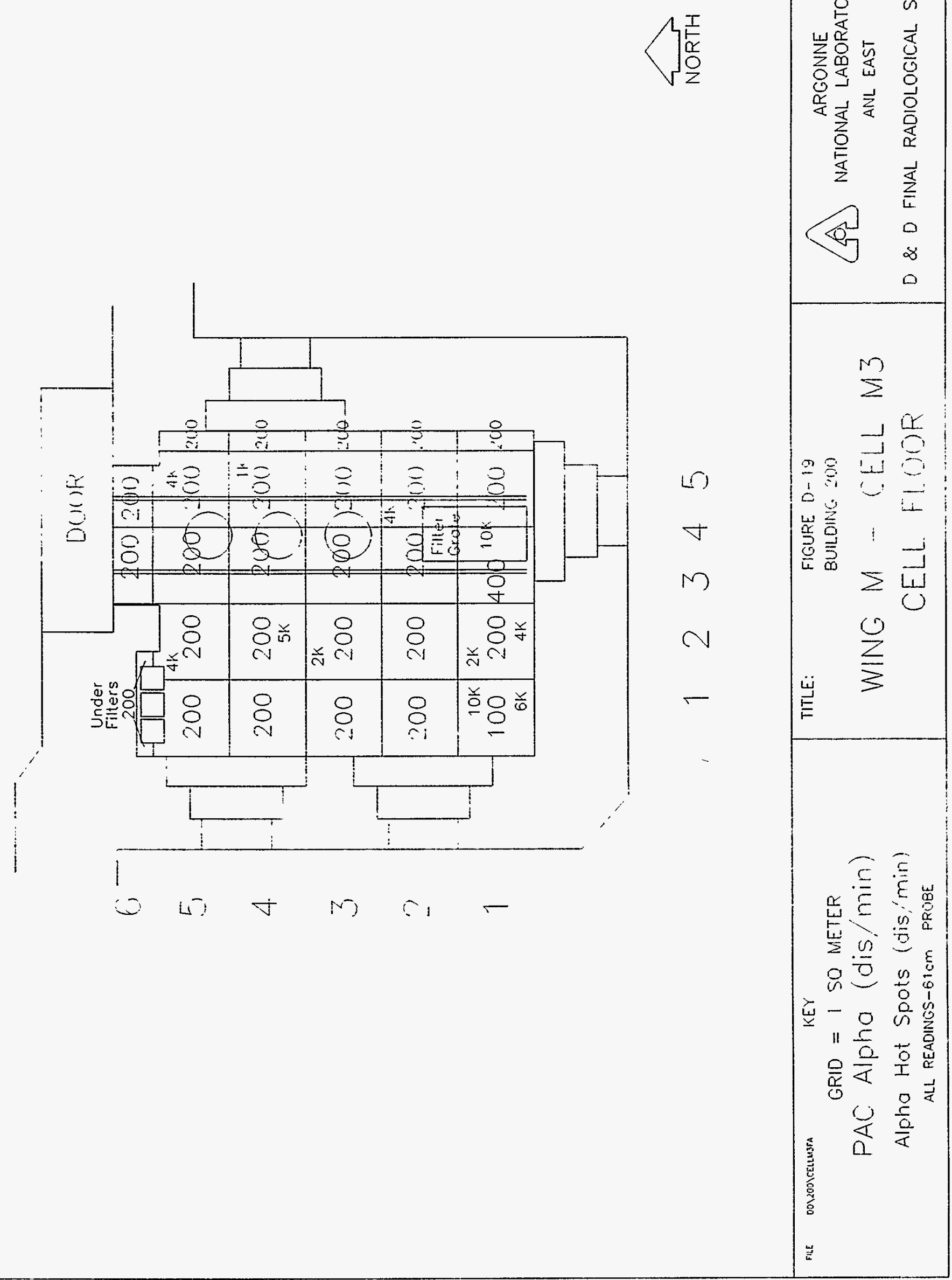




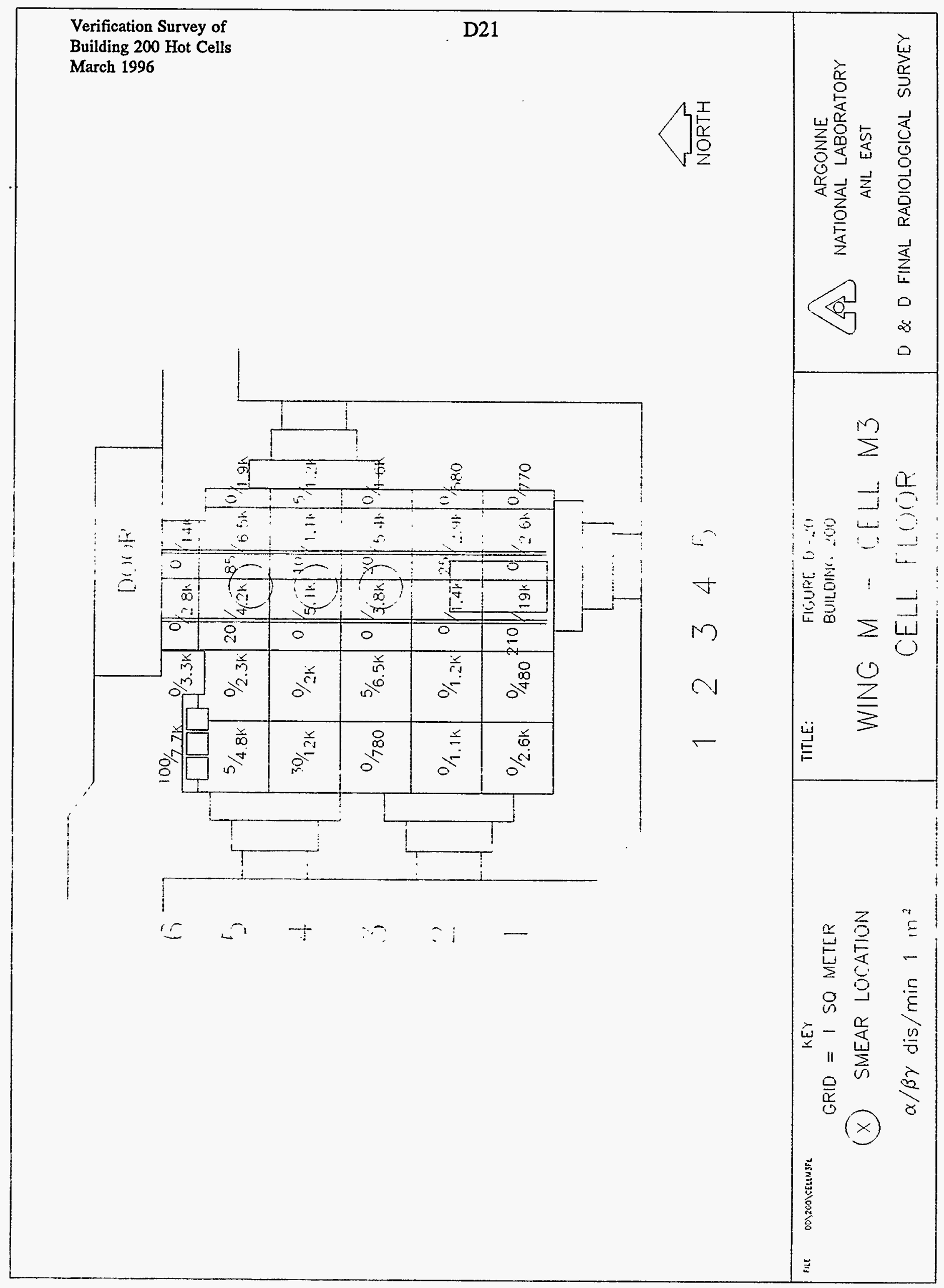




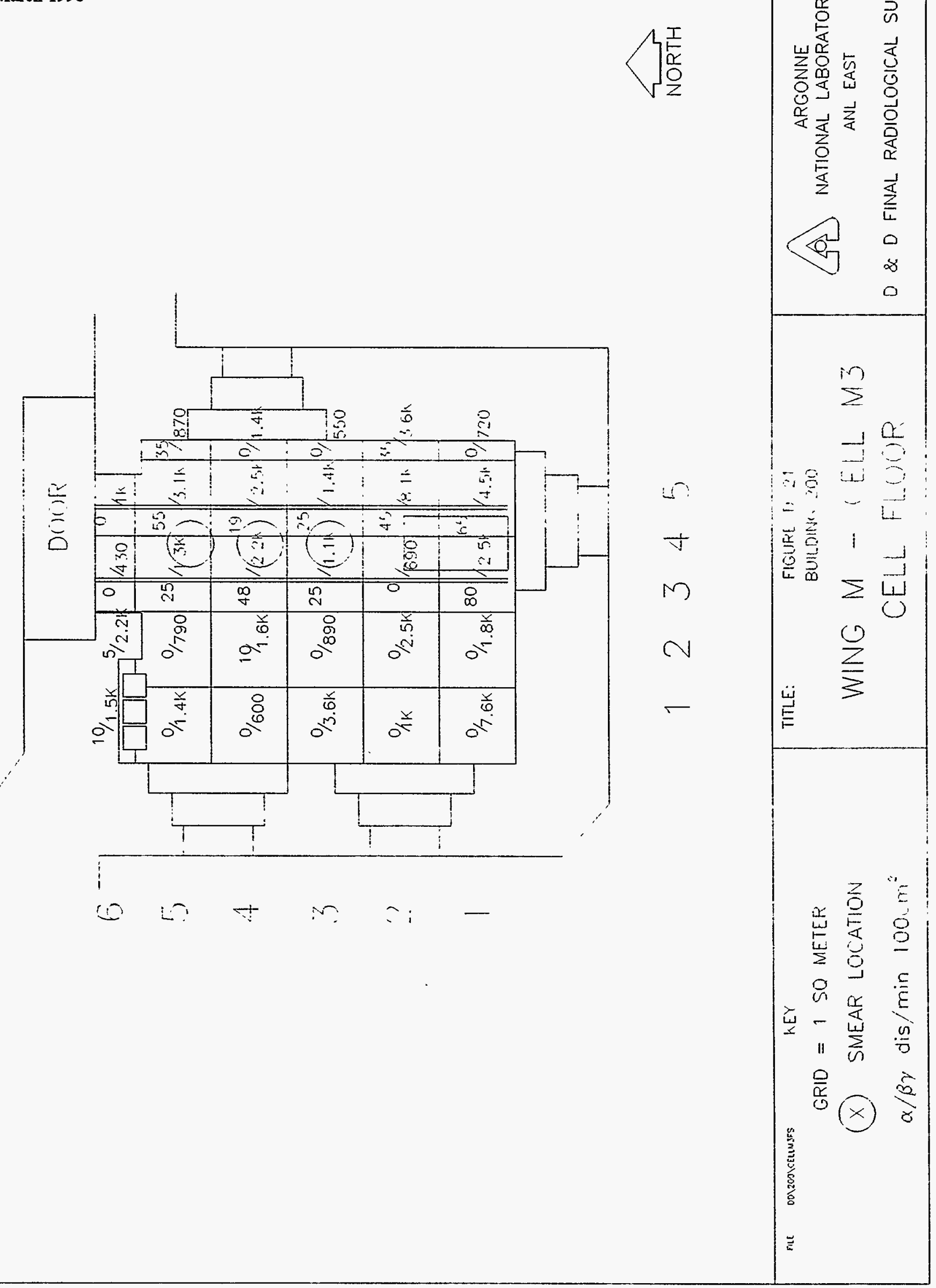




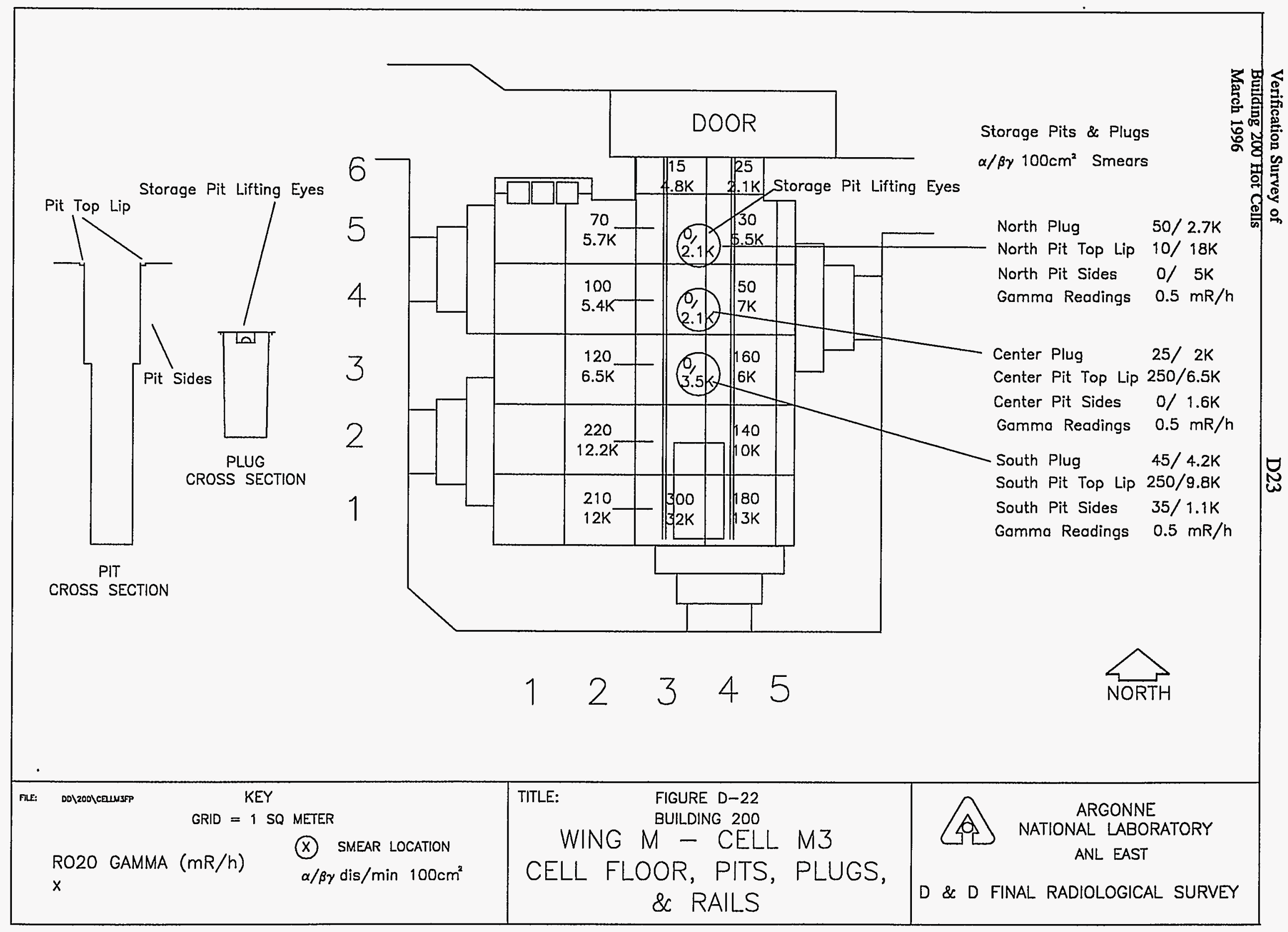




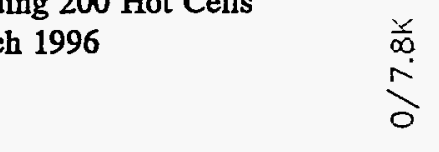

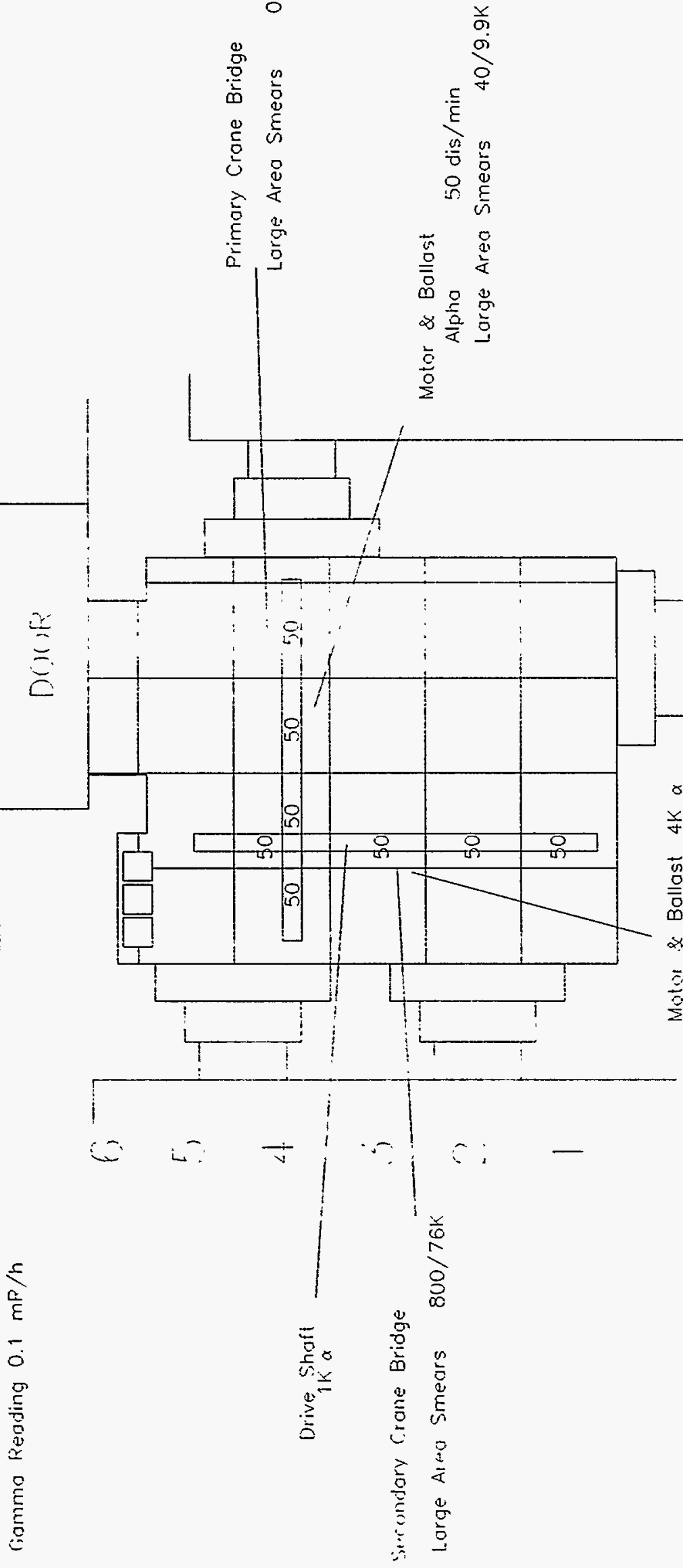

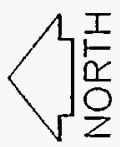

产 峁

山峞上京

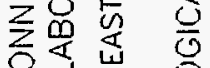

$\Rightarrow$

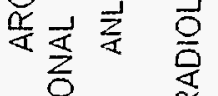

妾 만

$\sum \quad \frac{\vec{T}}{z}$

0

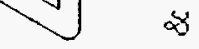

$\square$

$\sum$

a

in $\stackrel{a}{5}$

$\because 2 \pm \frac{0}{9}$

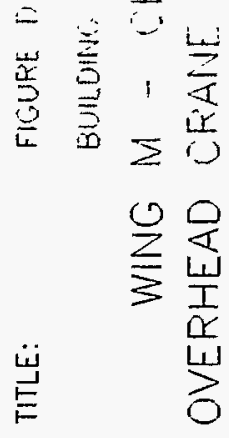

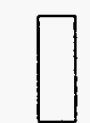

$\stackrel{y}{5}$

है
$-1$

$+$

$M$

N

$\leftarrow$

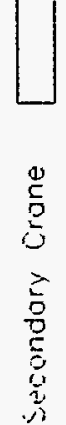




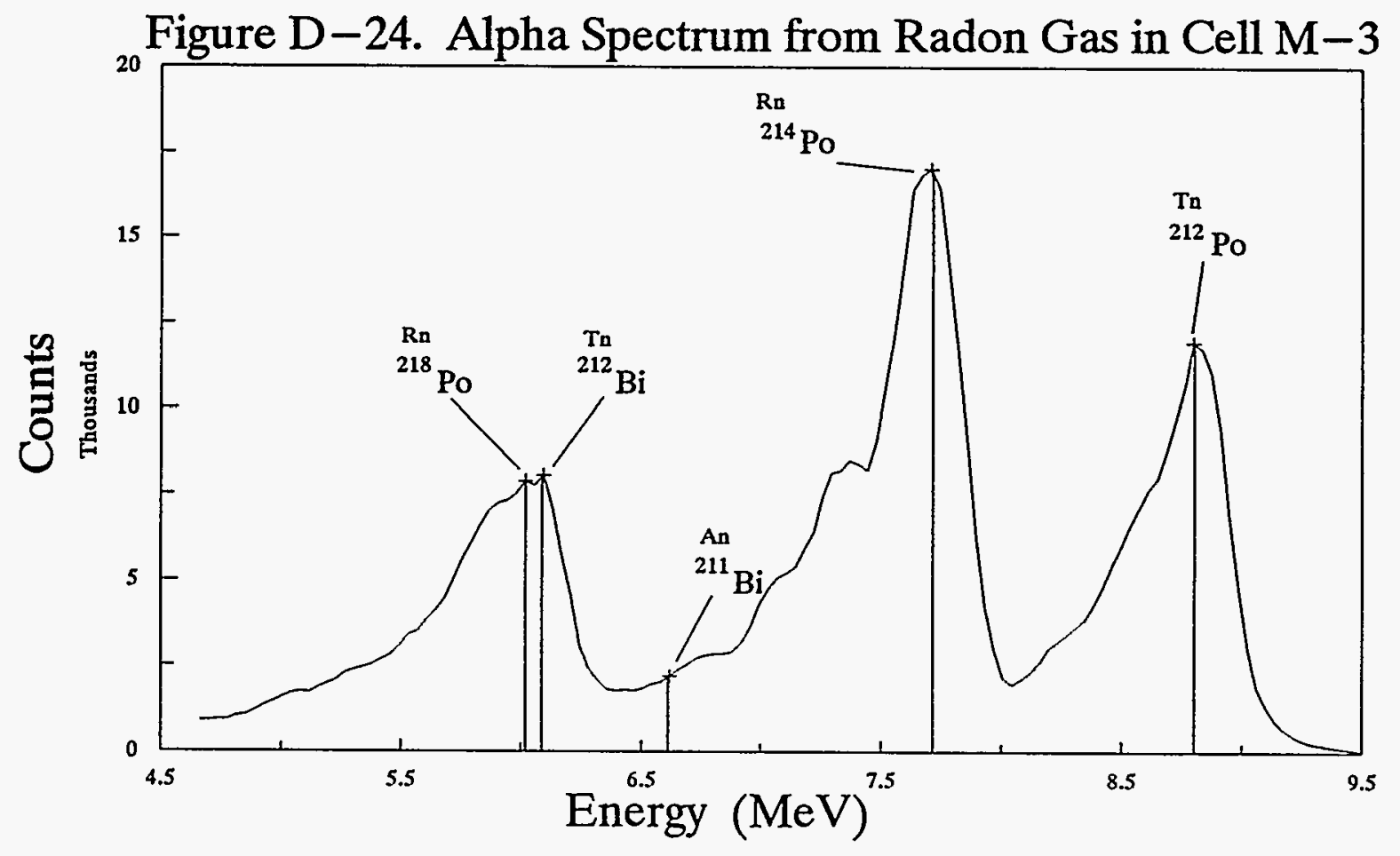

Figure D-25. Alpha-6 Rn \& Tn Activities in Cell M-3

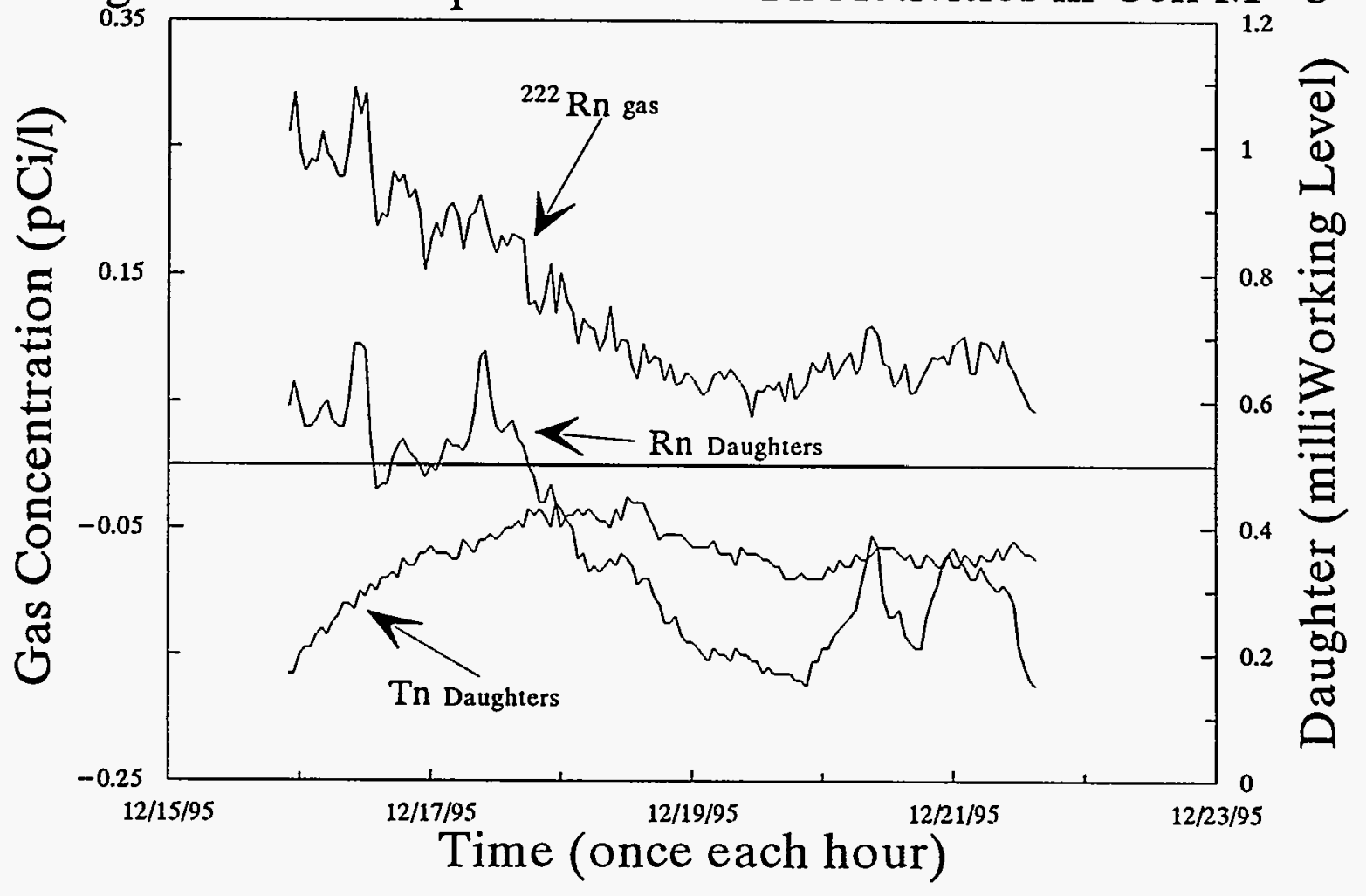


Figure D-26. Cell M-3 Discharge

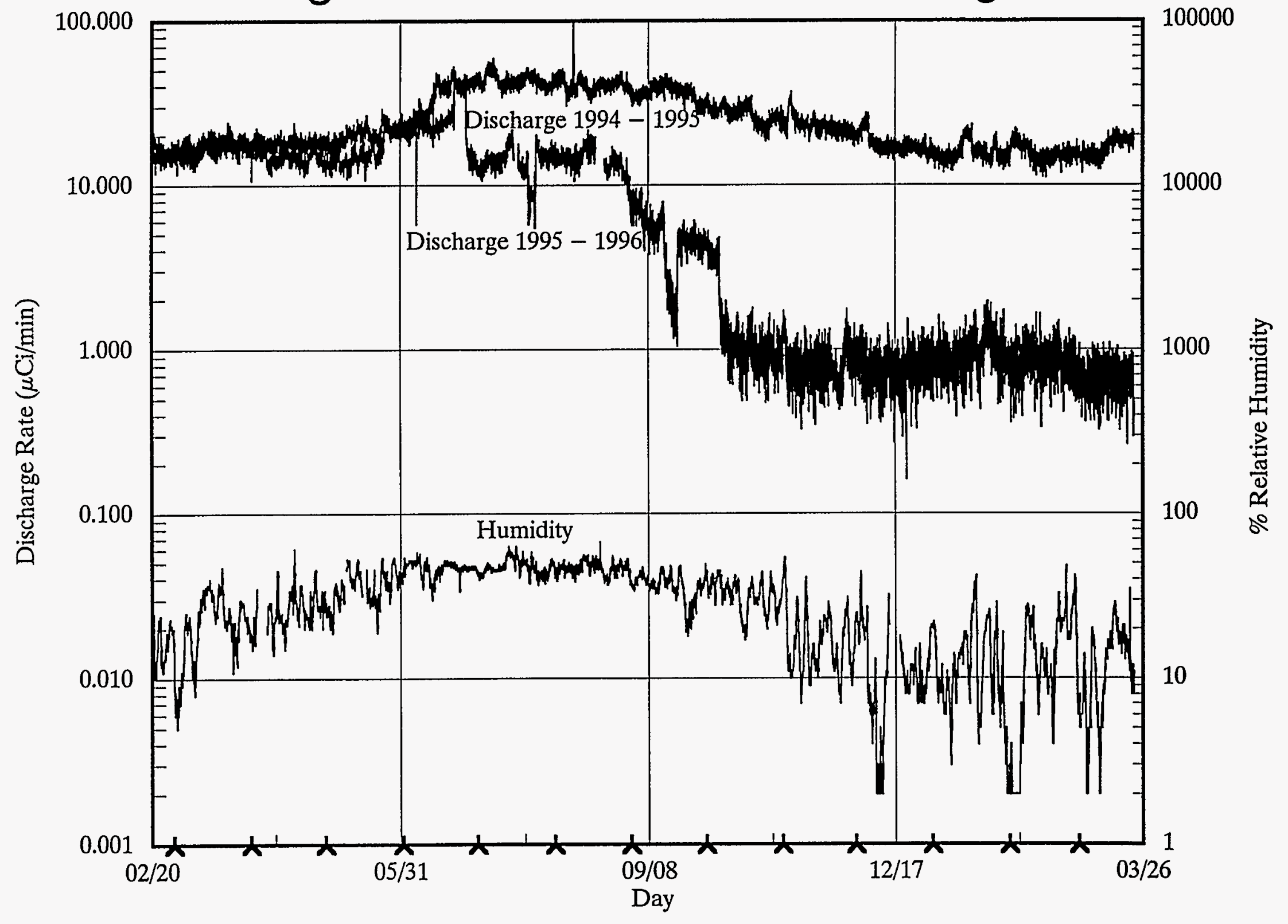


Verification Survey of Building 200 Hot Cells March 1996
E1

APPENDIX E Cell M-1 Figures 


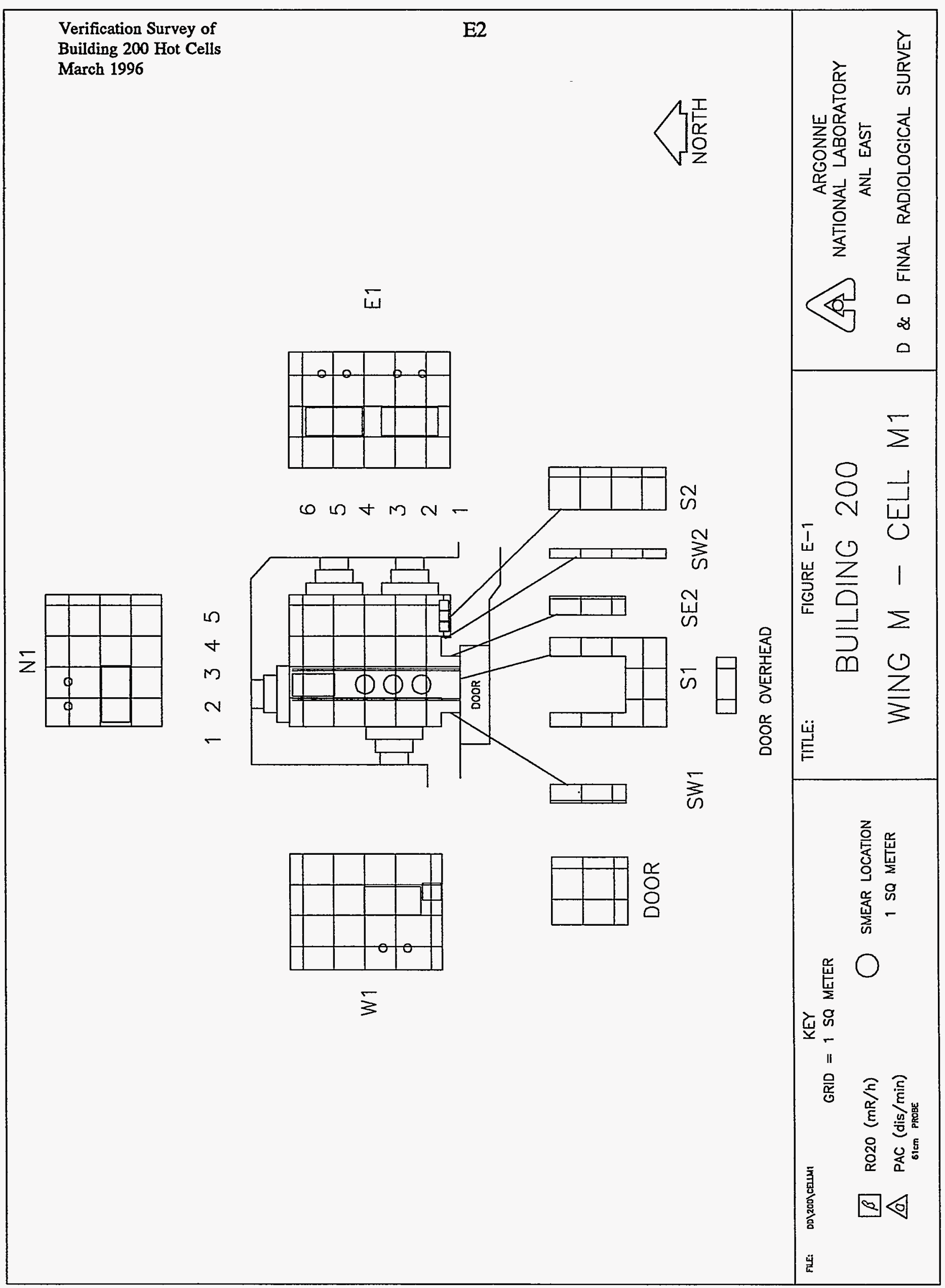




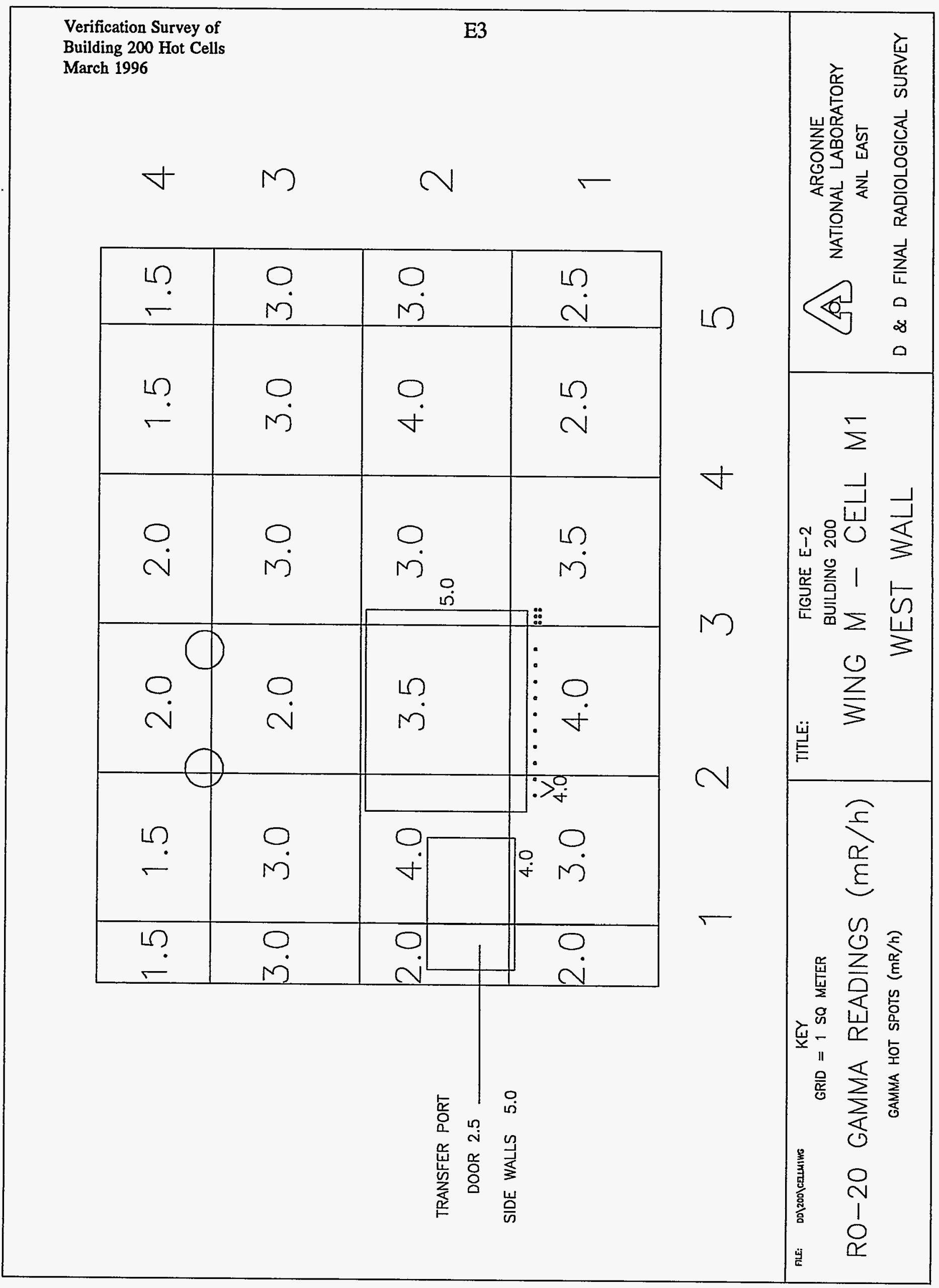




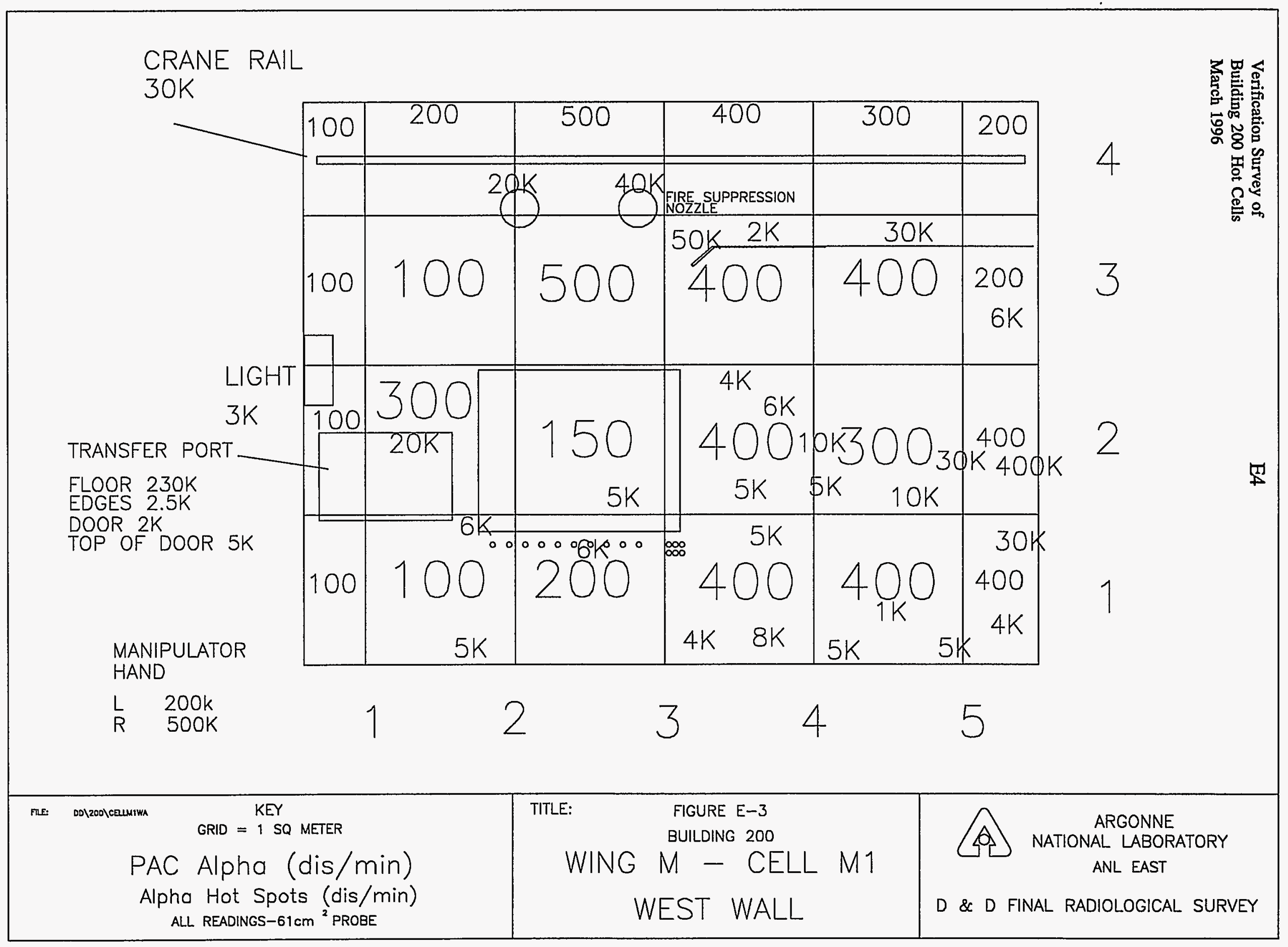




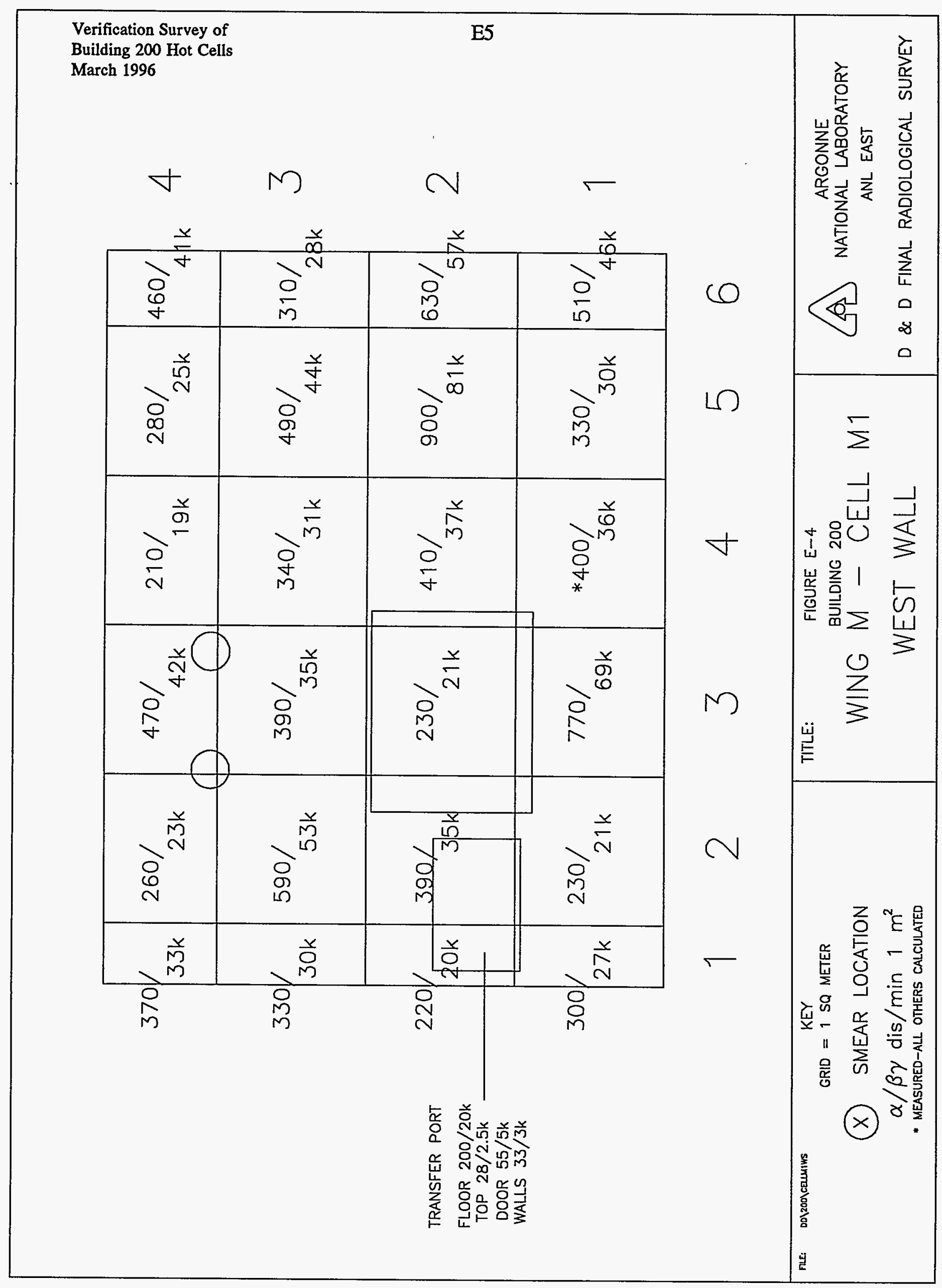



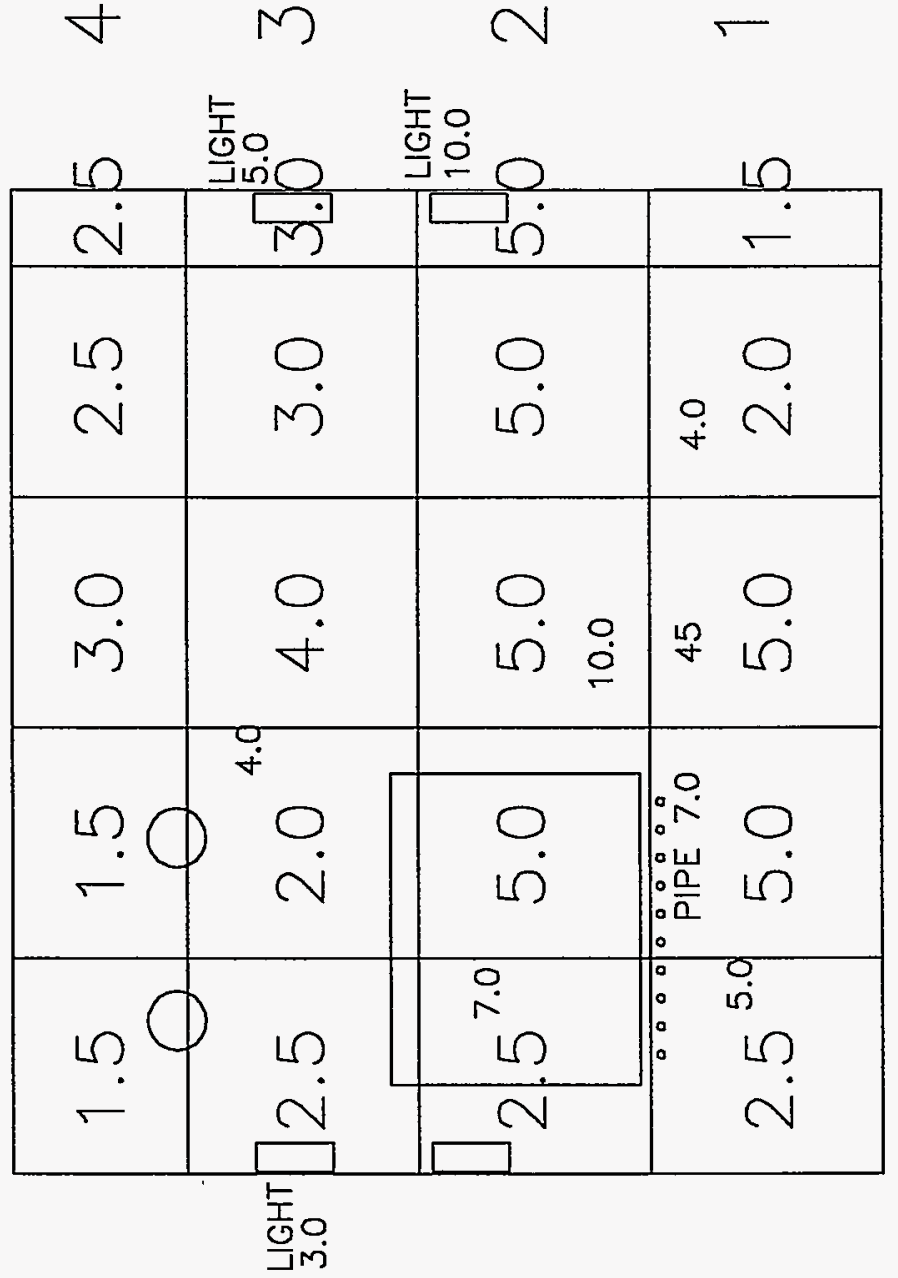

\llcorner

$\Sigma$

品

山

崖竞

।

$工$

$\checkmark$

N

$M$

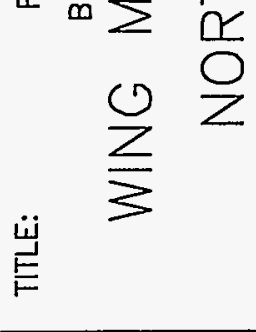

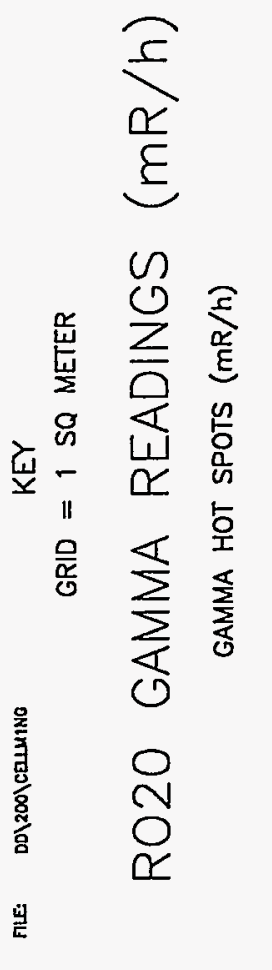




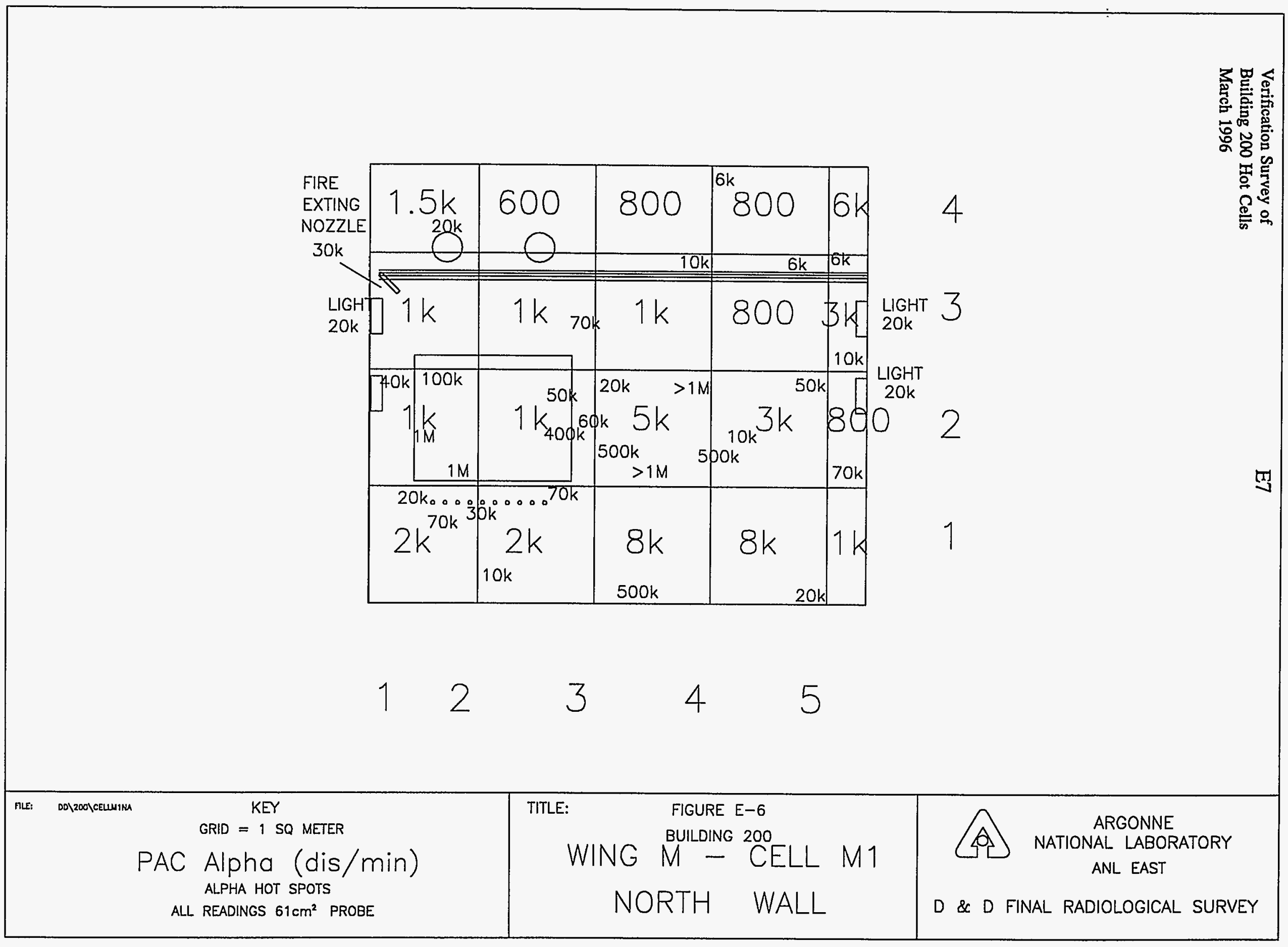




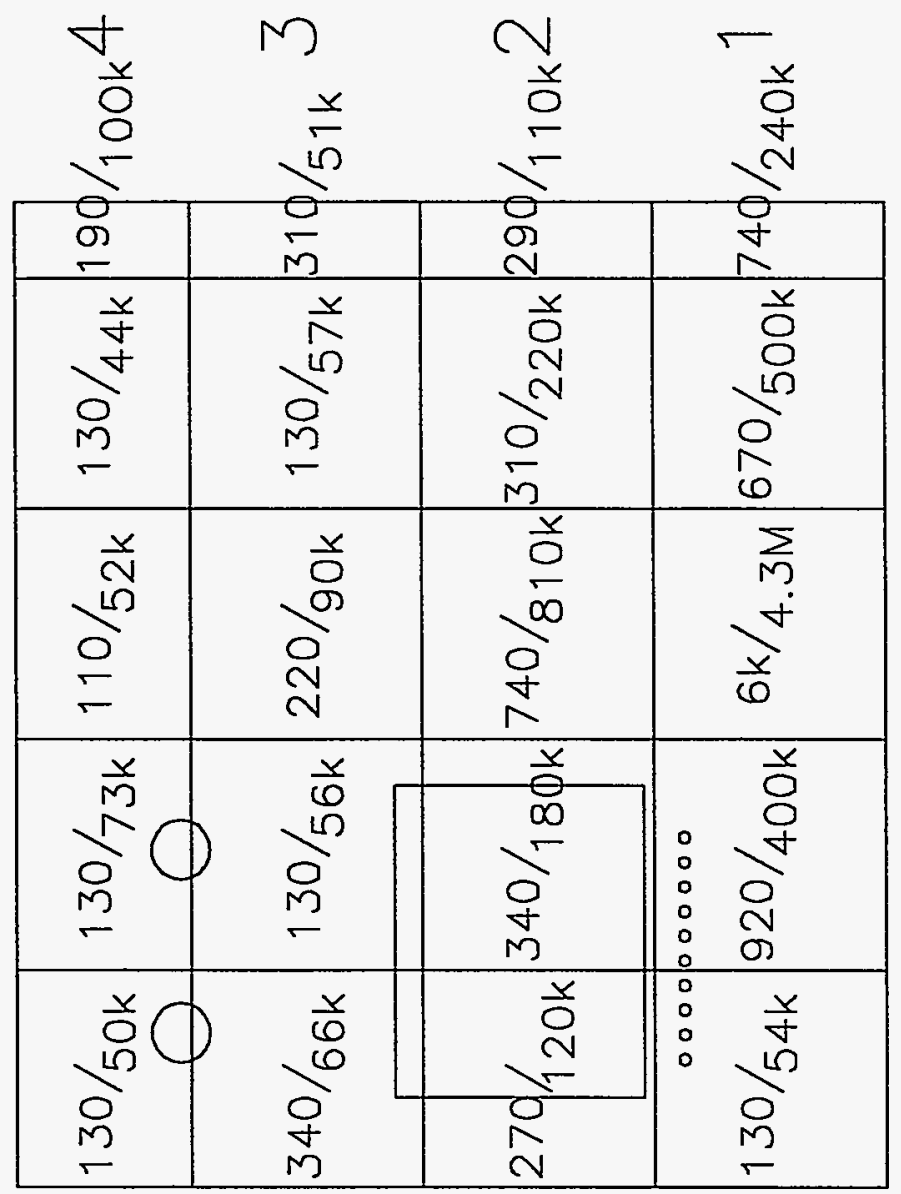

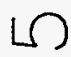

$\Sigma$

$\checkmark$

$M$

$\theta$
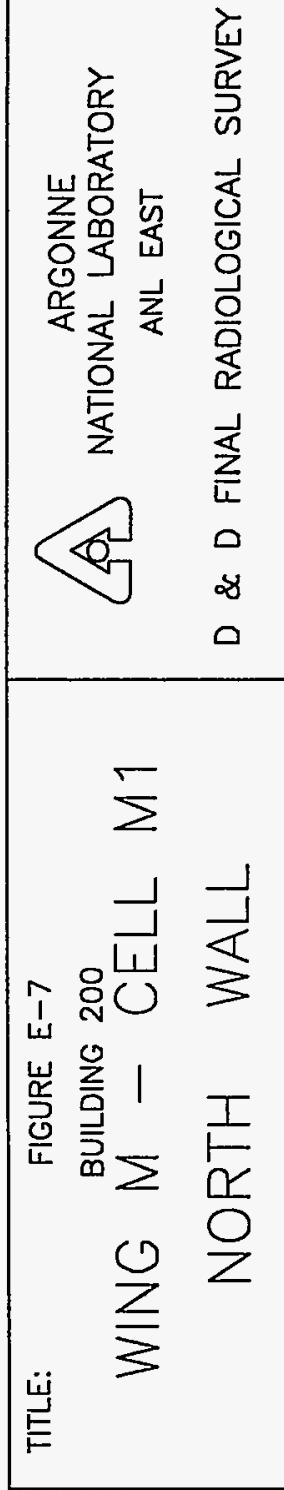

N

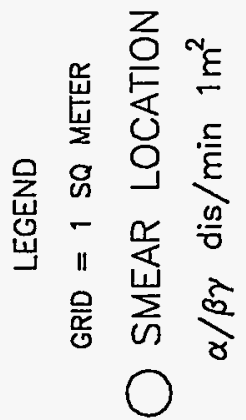




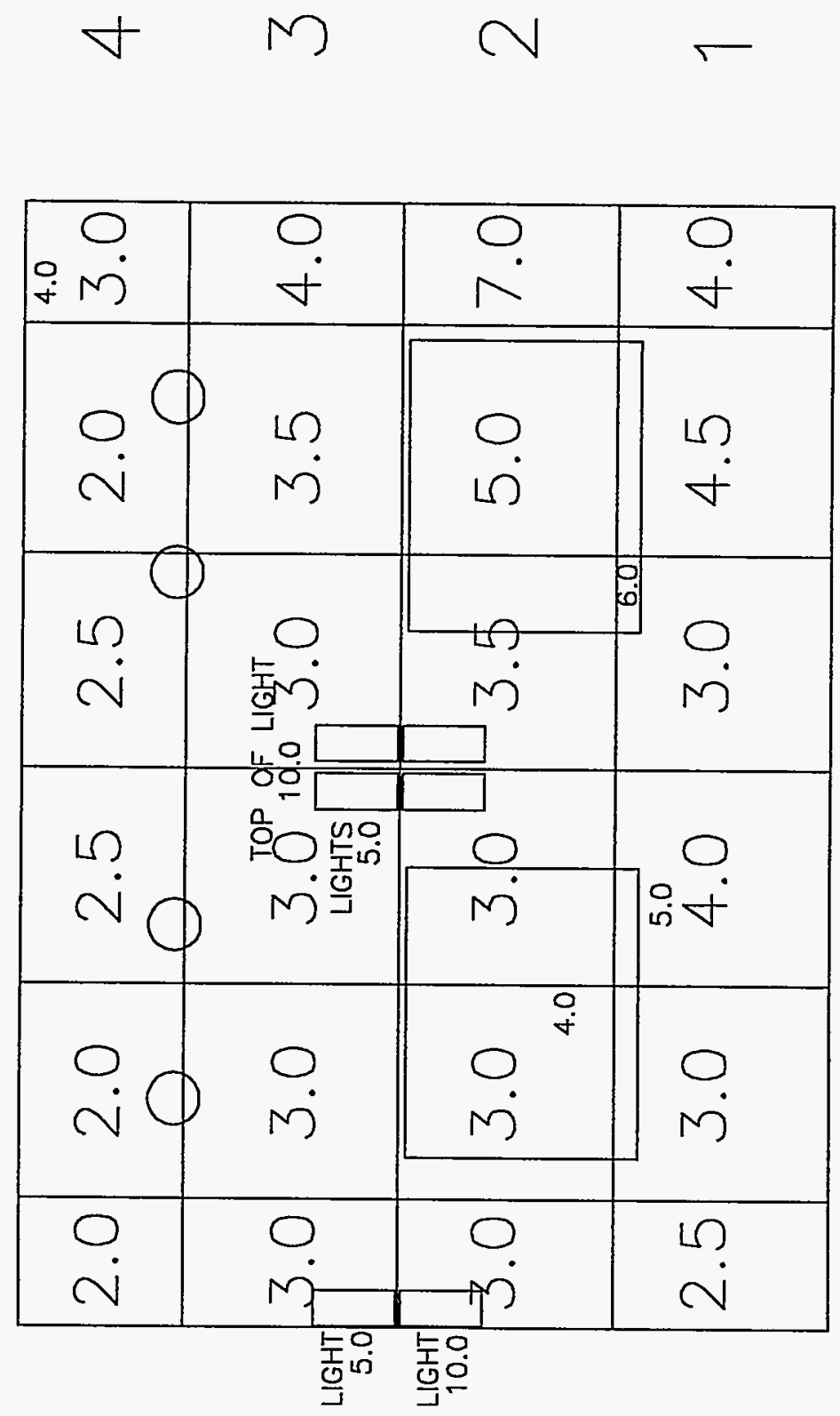

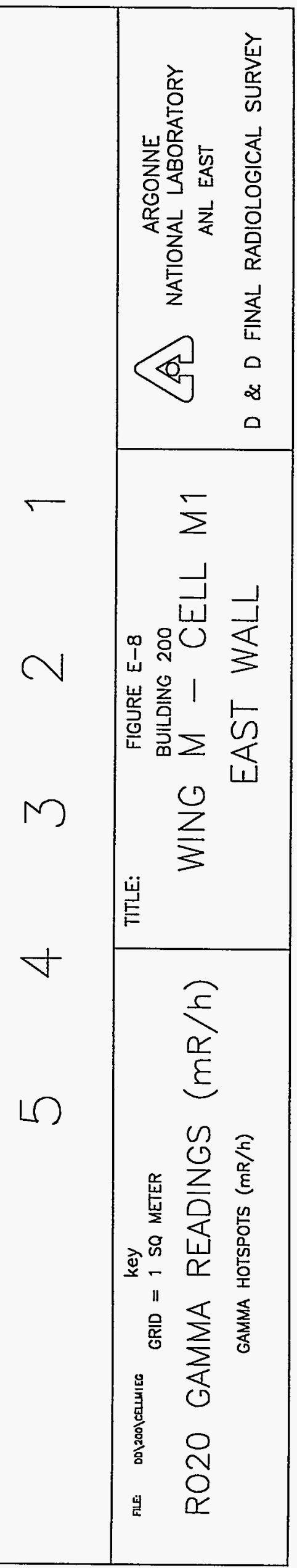


$\forall$

$m$

O

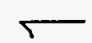



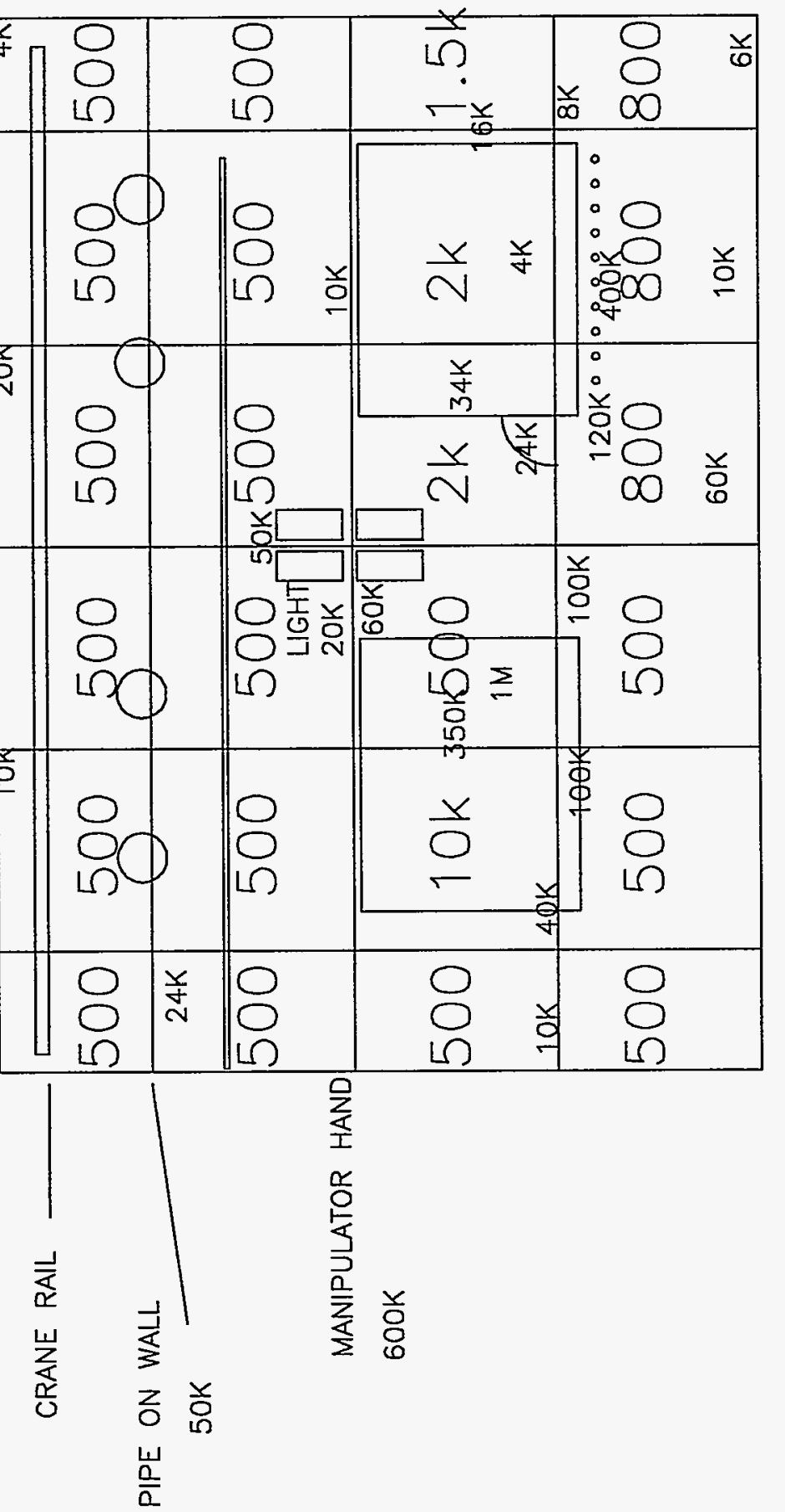

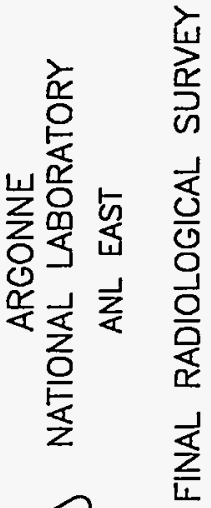

\&

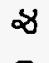

N

$\sum$

윤

w

宸

는 蒠

$M$

$\stackrel{\vec{F}}{E}$

L

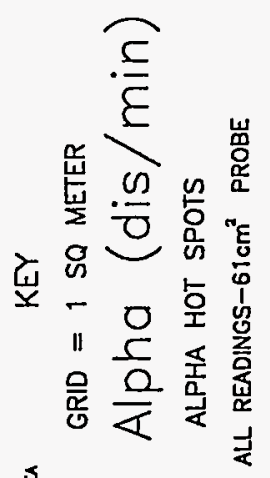

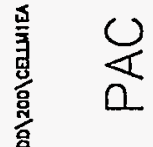




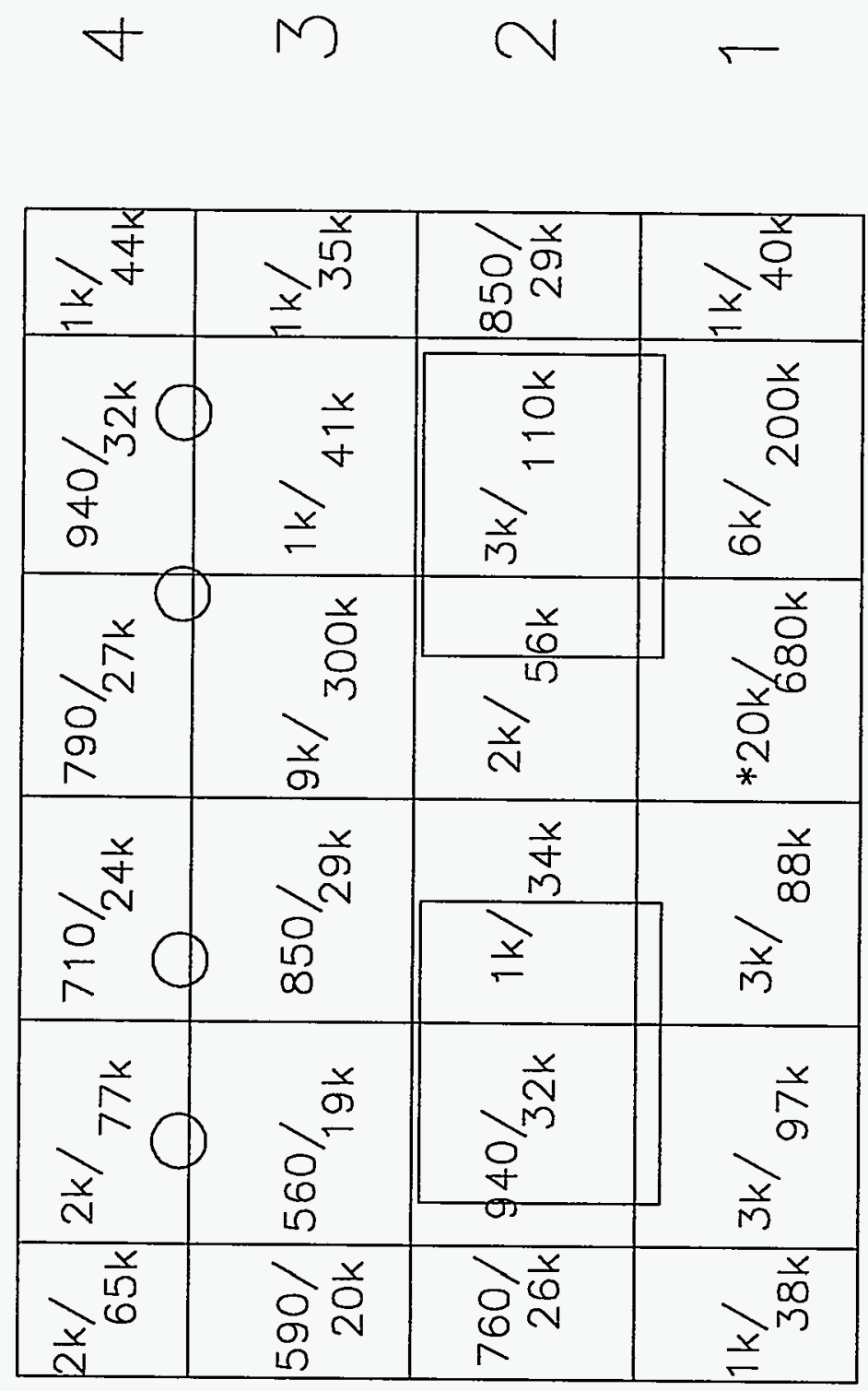

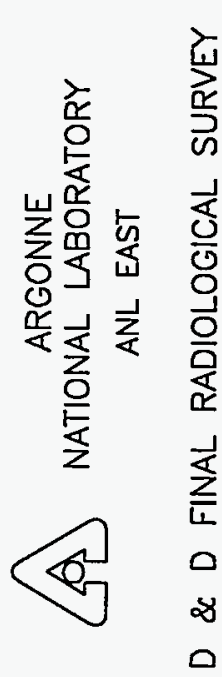

$\Sigma$

$\mathrm{V}$

$N$

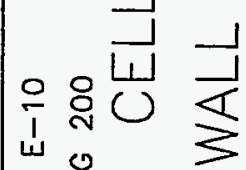

宸

$\sum \frac{1}{4}$

$\stackrel{0}{\sum}$

芦

$4 \Omega$

(O) 
Verification Survey of

Building 200 Hot Cells

March 1996
E12

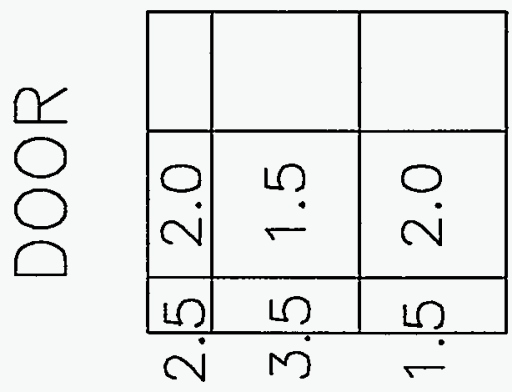

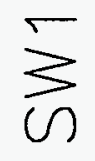

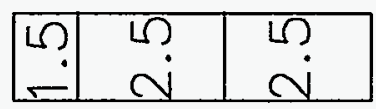

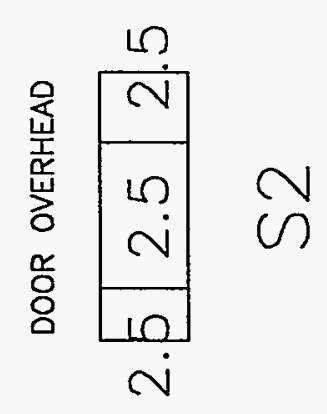

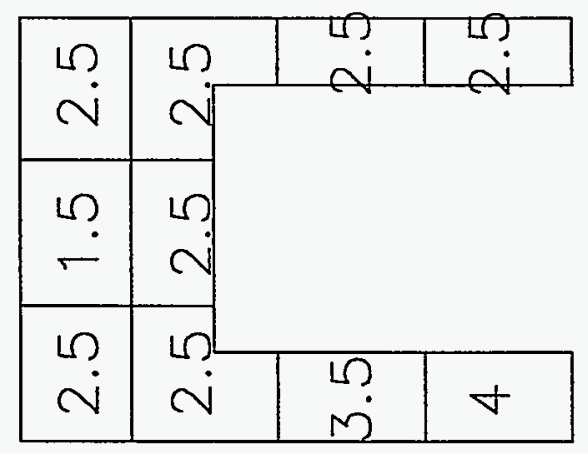

एँ

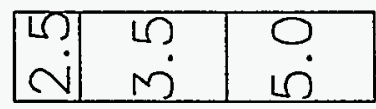

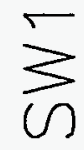

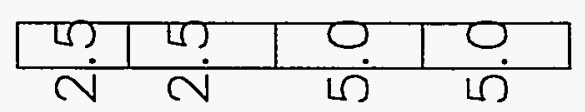

is \ulcorner

N

$M$

$\checkmark$

N

$M$

$\checkmark$

$\sum$

ㄴ.

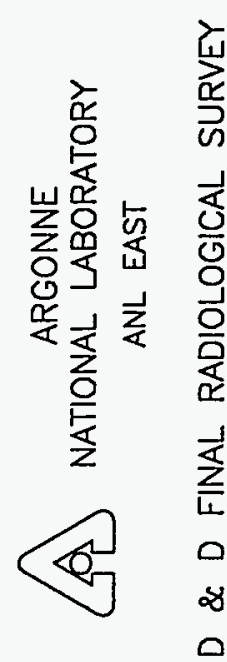

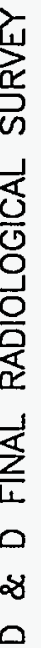

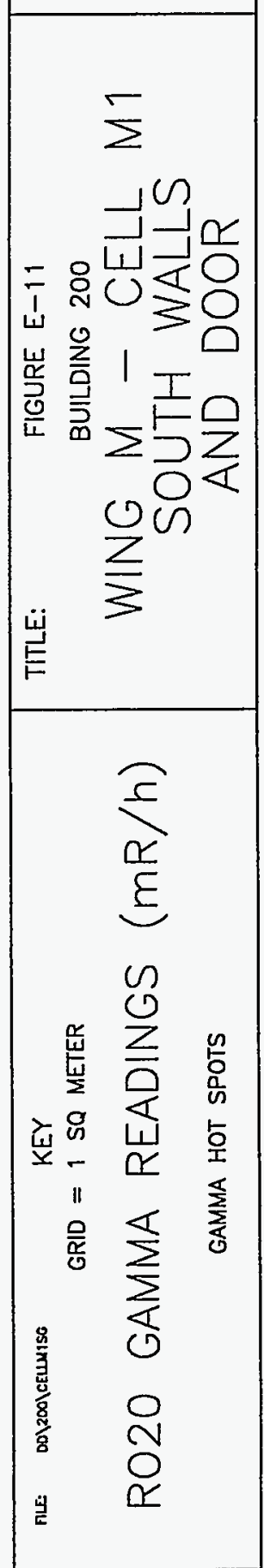




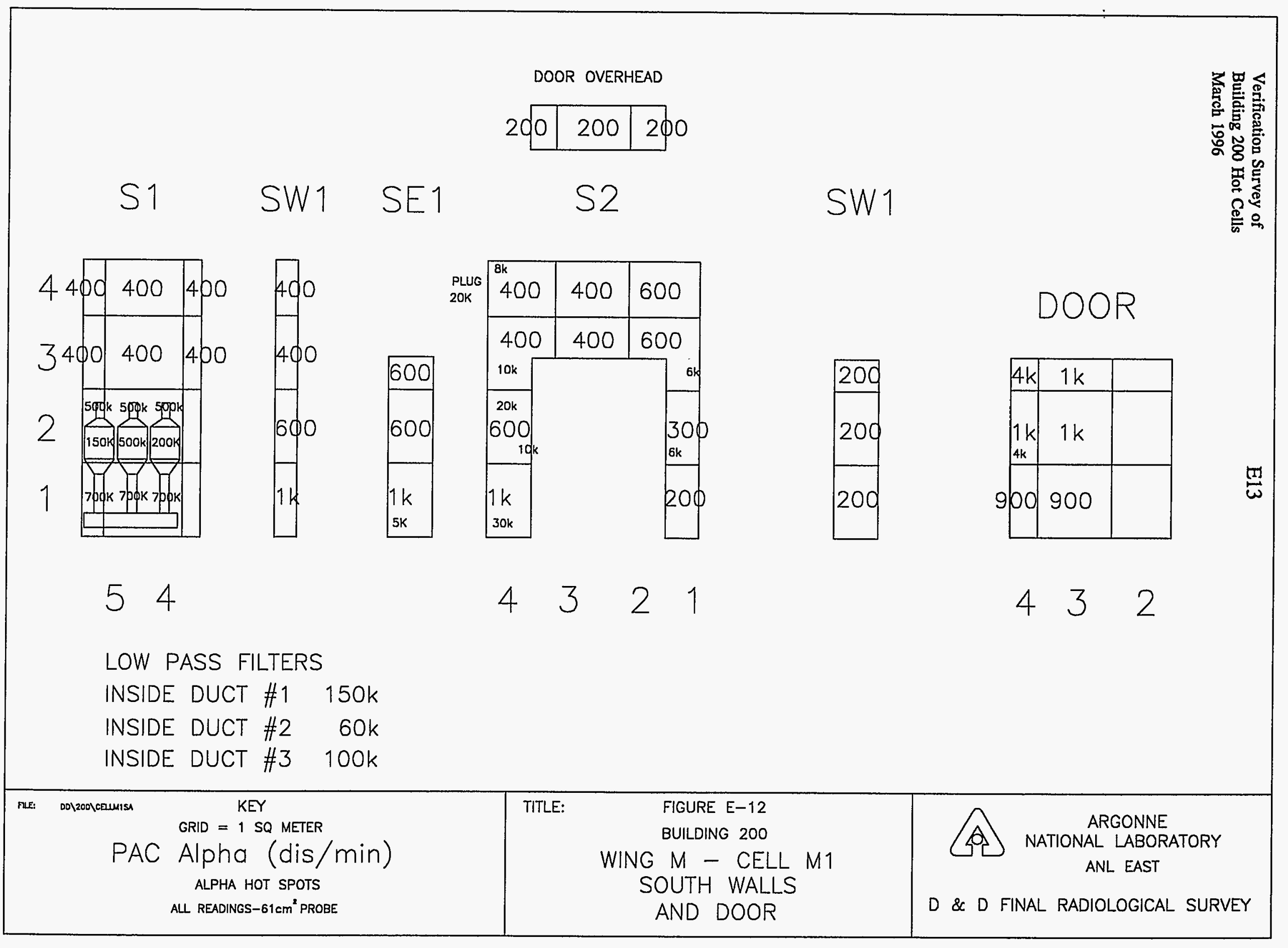




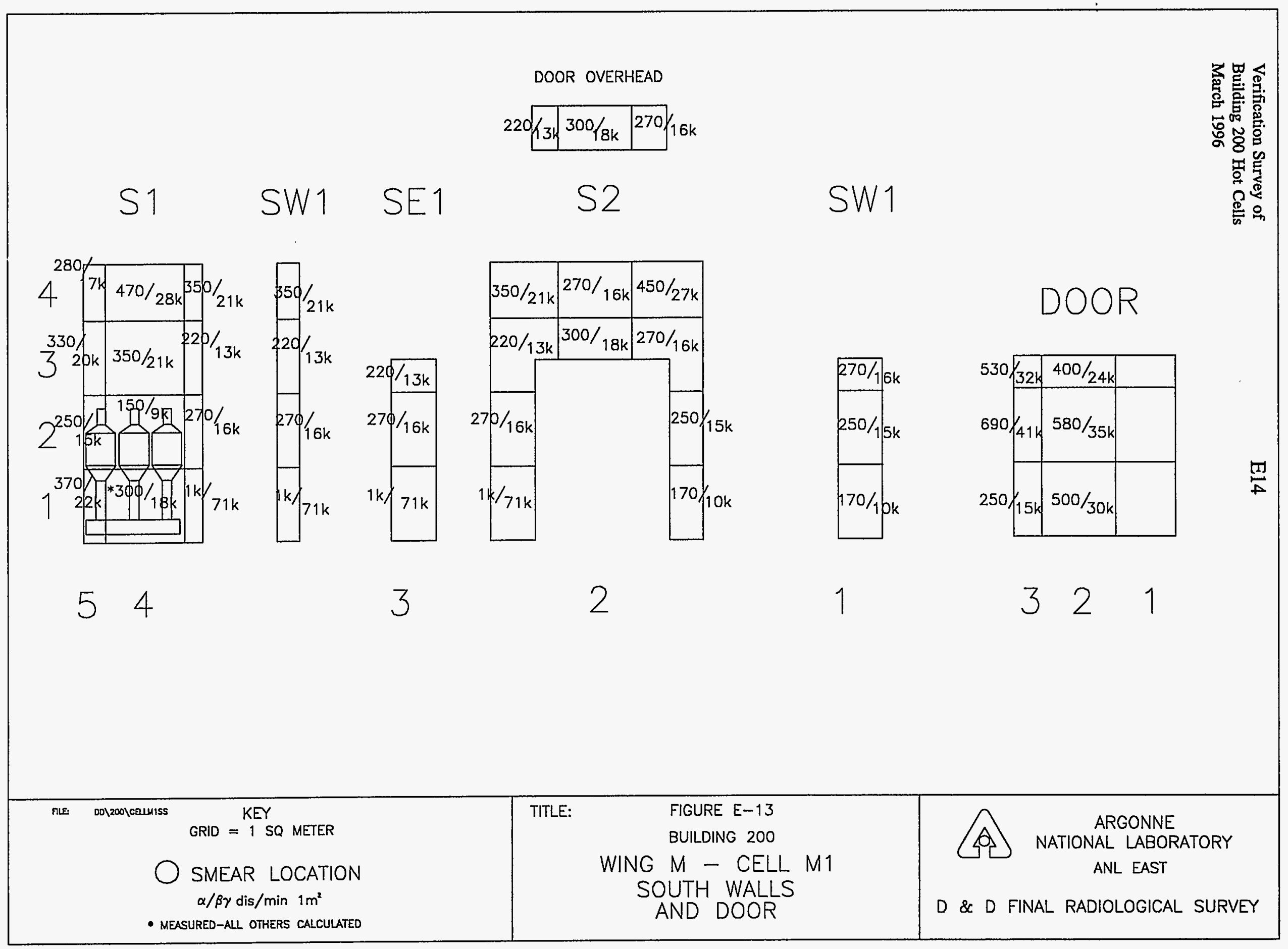




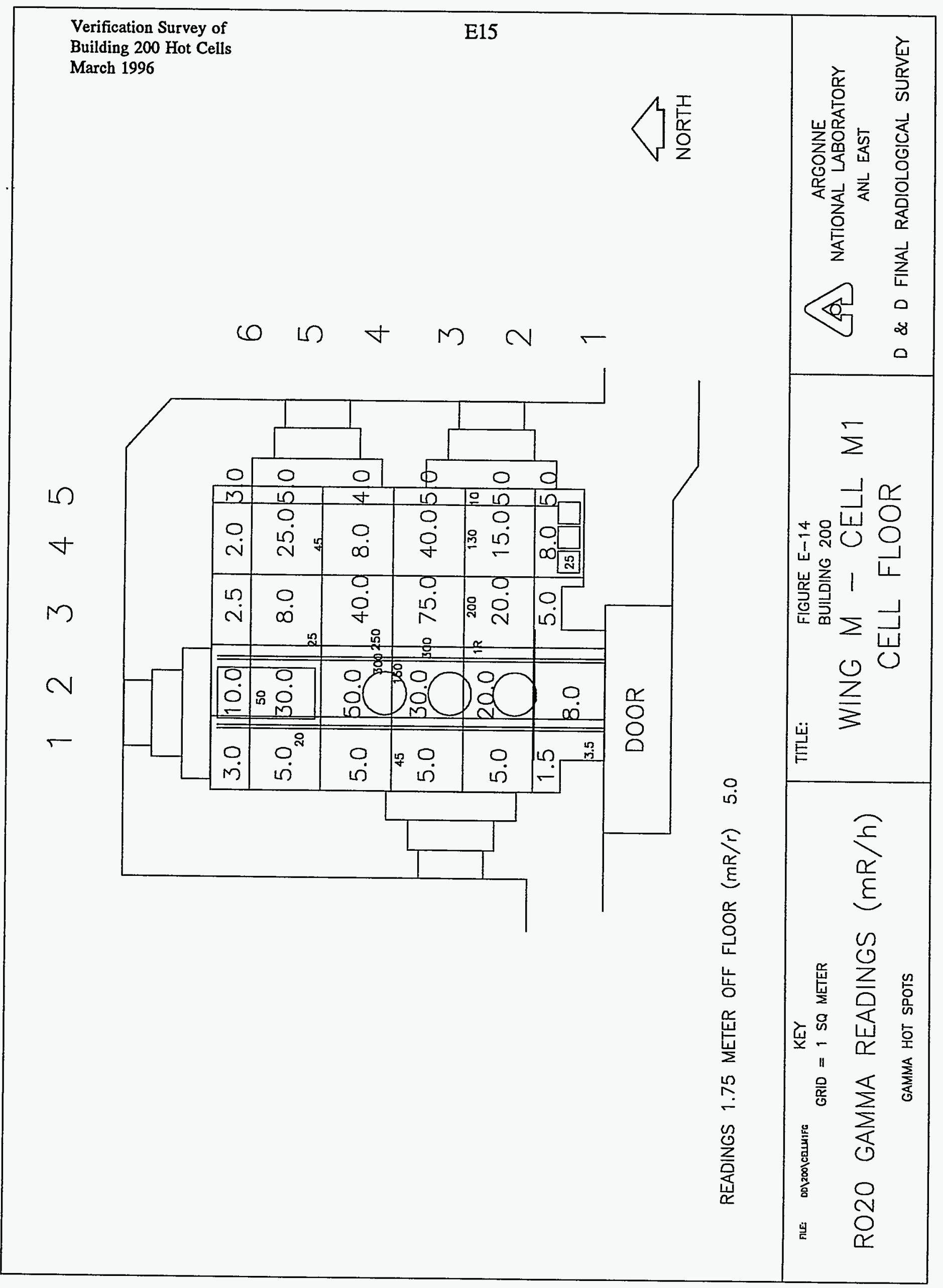




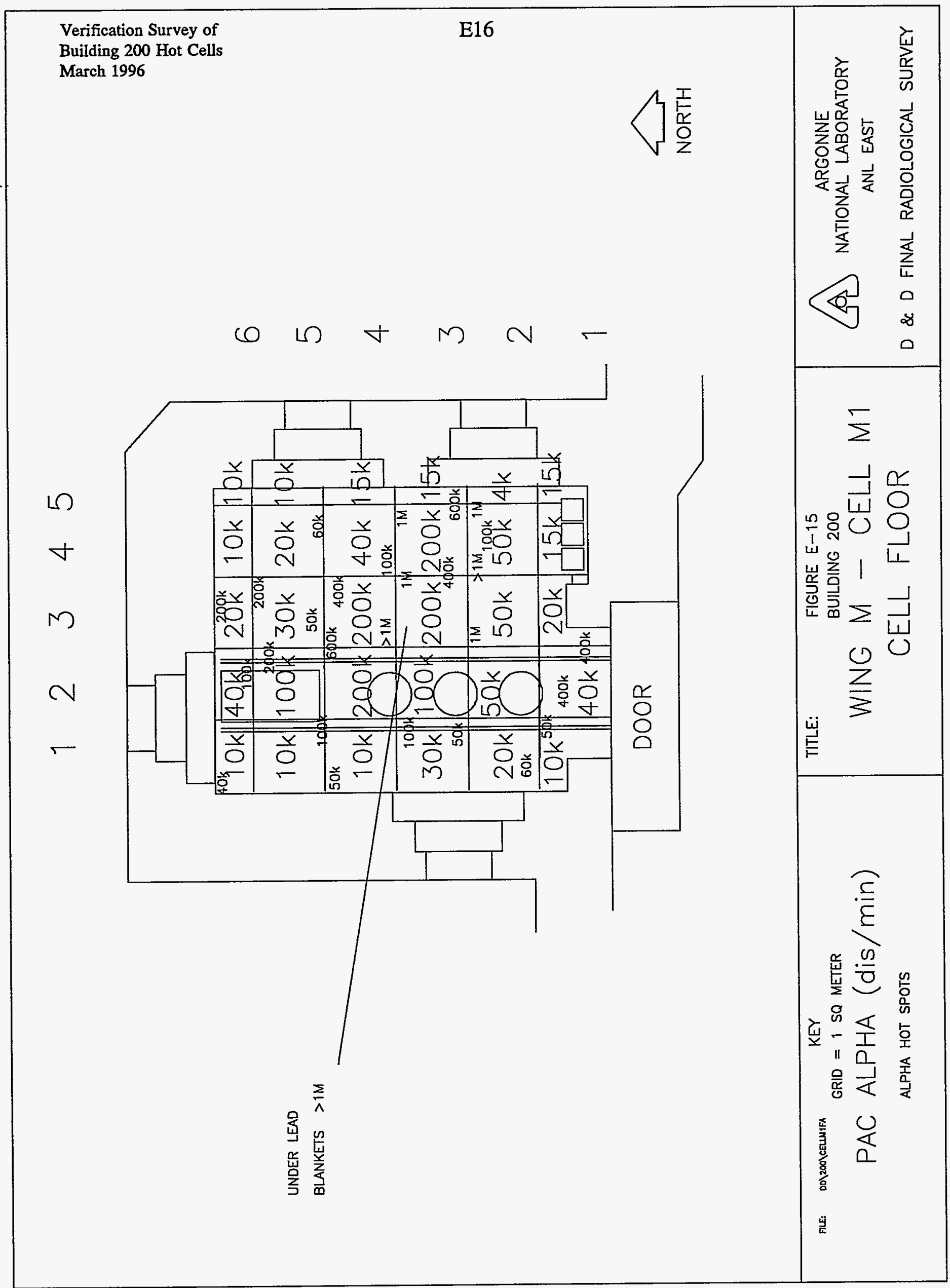




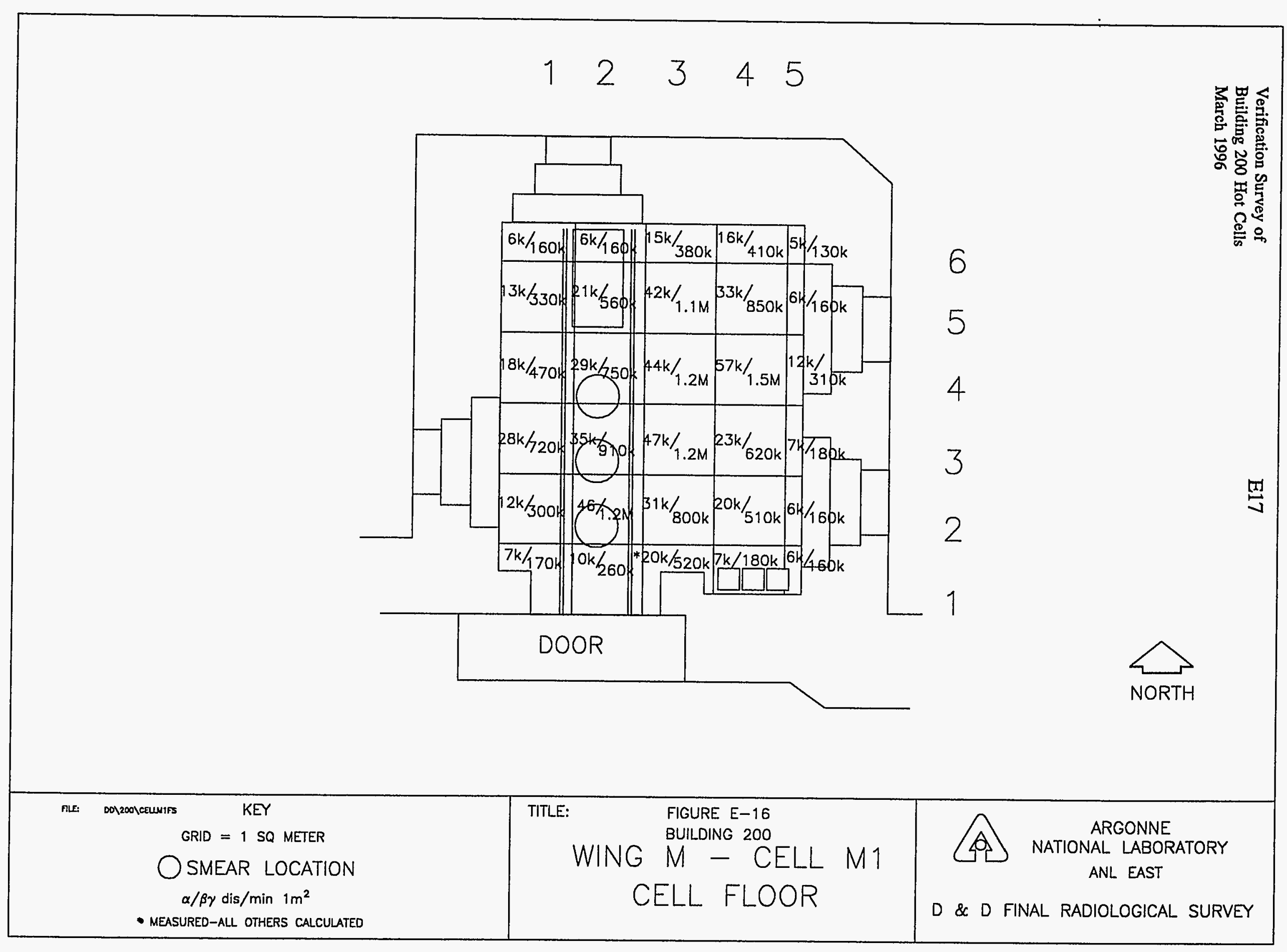


Verification Survey of

Building 200 Hot Cells

March 1996

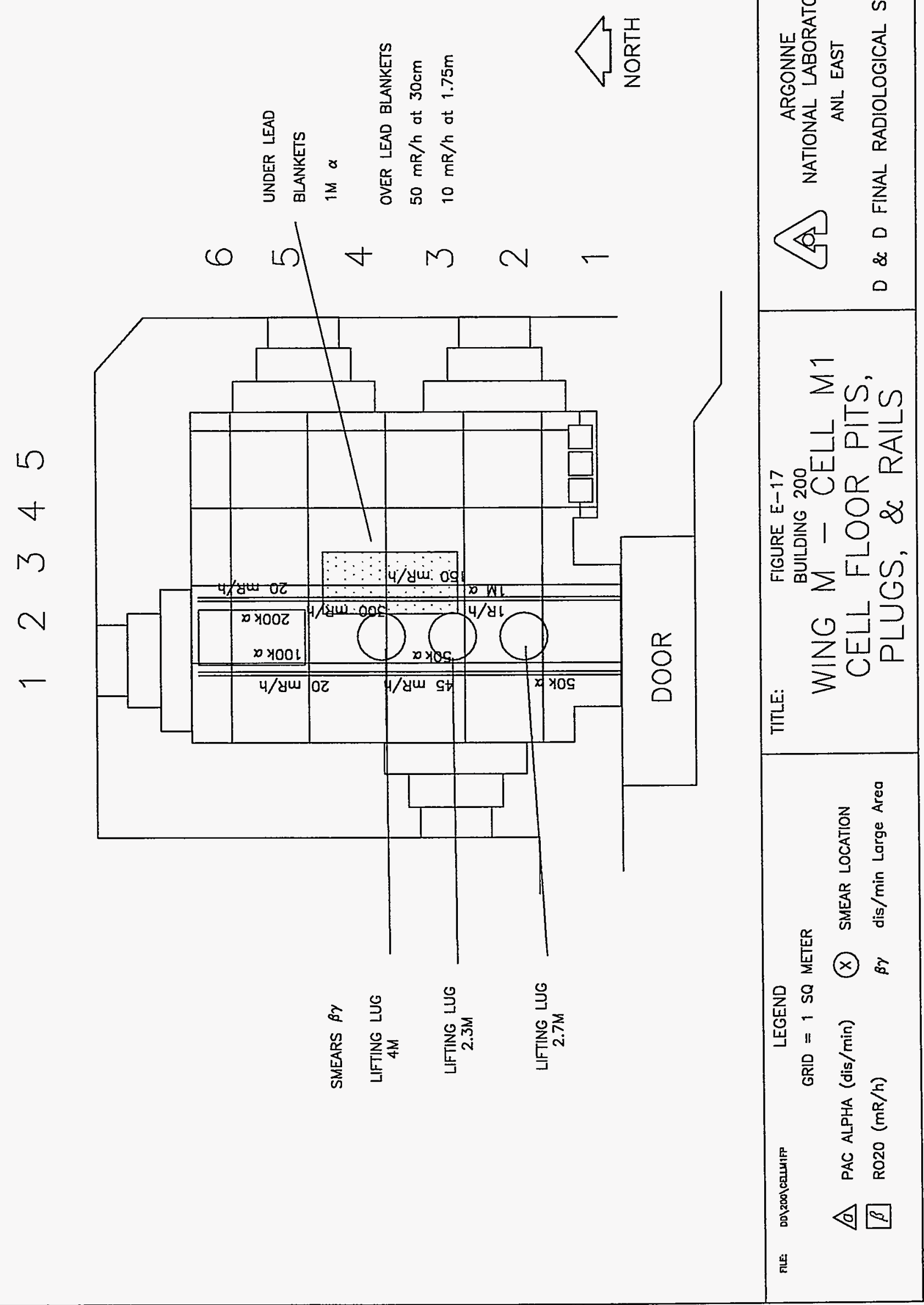




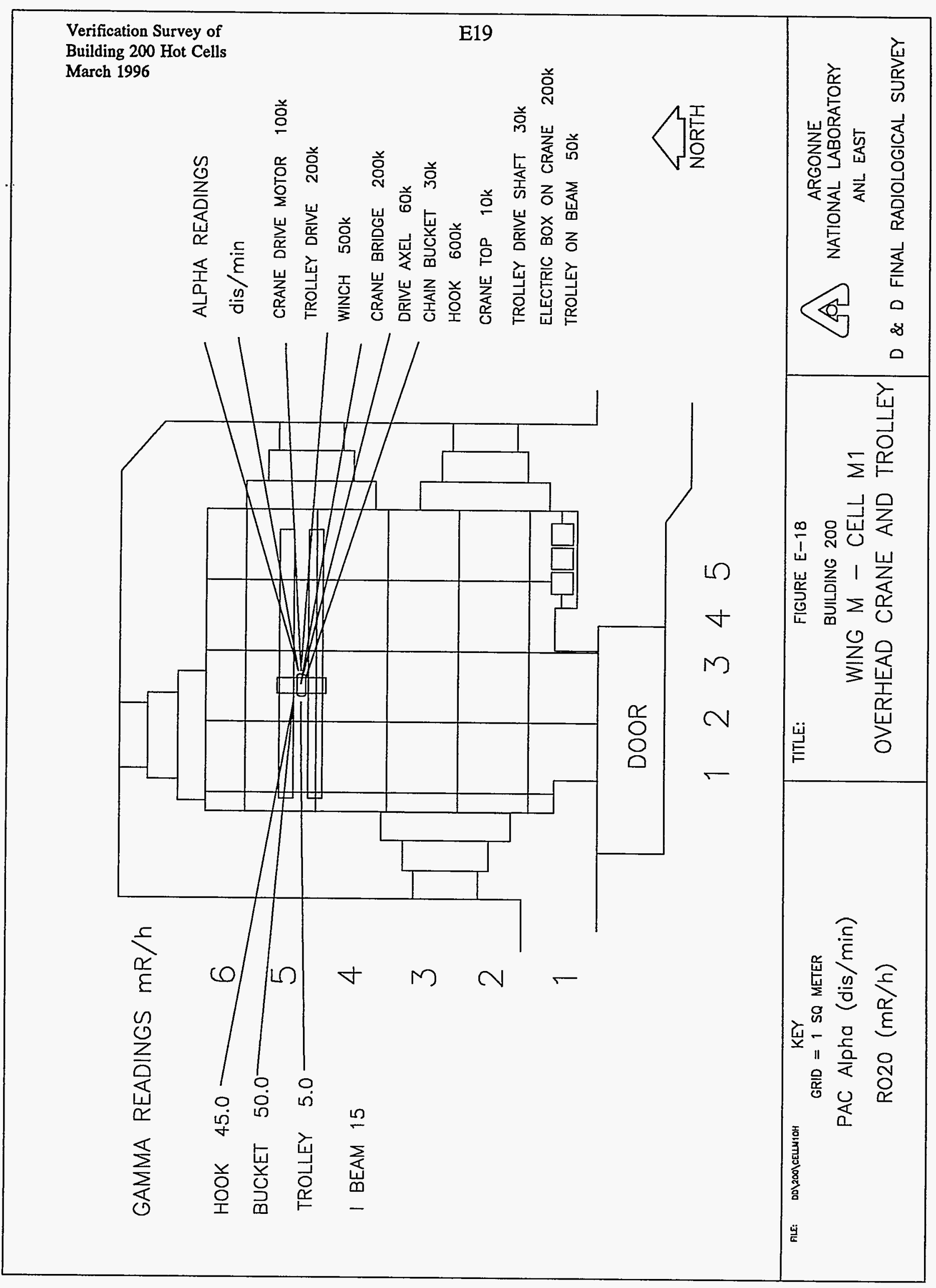



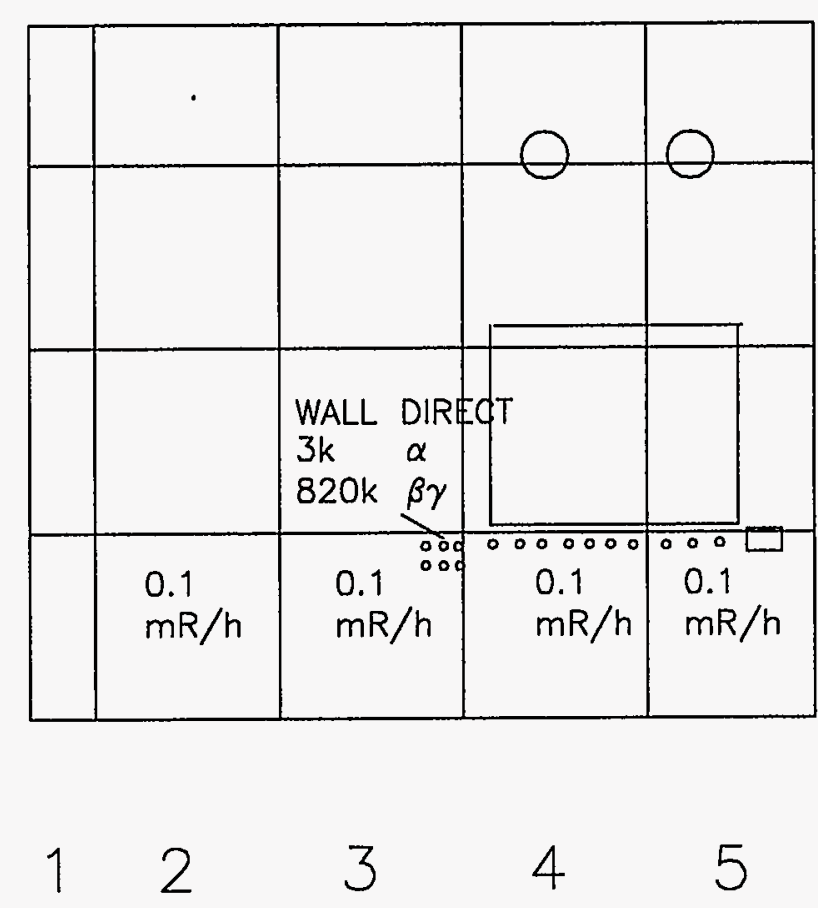

3

\begin{tabular}{|l|l|c|lr|r|}
\hline & (1) (2) & (3) & (4) & (5) \\
& 0.1 & 0.1 & 0.1 & 0.1 \\
$\mathrm{mR} / \mathrm{h}$ & $\mathrm{mR} / \mathrm{h}$ & $\mathrm{mR} / \mathrm{h}$ & $\mathrm{mR} / \mathrm{h}$ \\
\hline & & & & \\
& & & & \\
\hline
\end{tabular}

FLOOR
FLOOR DIRECTS TAKEN WITH NE

ALL READINGS/dis min

1

$\begin{array}{lll}\text { (1) } & 170 & \alpha \\ & 6500 & \beta \gamma \\ & & \\ & & \\ & 100 & \alpha \\ \text { (2) } & 12 \mathrm{k} & \beta \gamma\end{array}$

(3) $\begin{array}{ll}270 & \alpha \\ 110 k & \beta \gamma\end{array}$

(4) $420 \alpha$

390k $\beta \gamma$

(5) $\begin{array}{ll}170 & \alpha \\ 68 \mathrm{k} & \beta \gamma\end{array}$

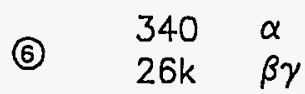

FIS DD/200/CWVIOT KEY GRID $=1$ SQ METER ELECTRA NE (dis/min) RO20 GAMMA READINGS $(\mathrm{mR} / \mathrm{h})$
TITLE:

FIGURE-19

BUILDING 200

WING M - CELL M1 NORTH WALL-OUT SIDE
A. ARGONNE ANL EAST

D \& D FINAL RADIOLOGICAL SURVEY 

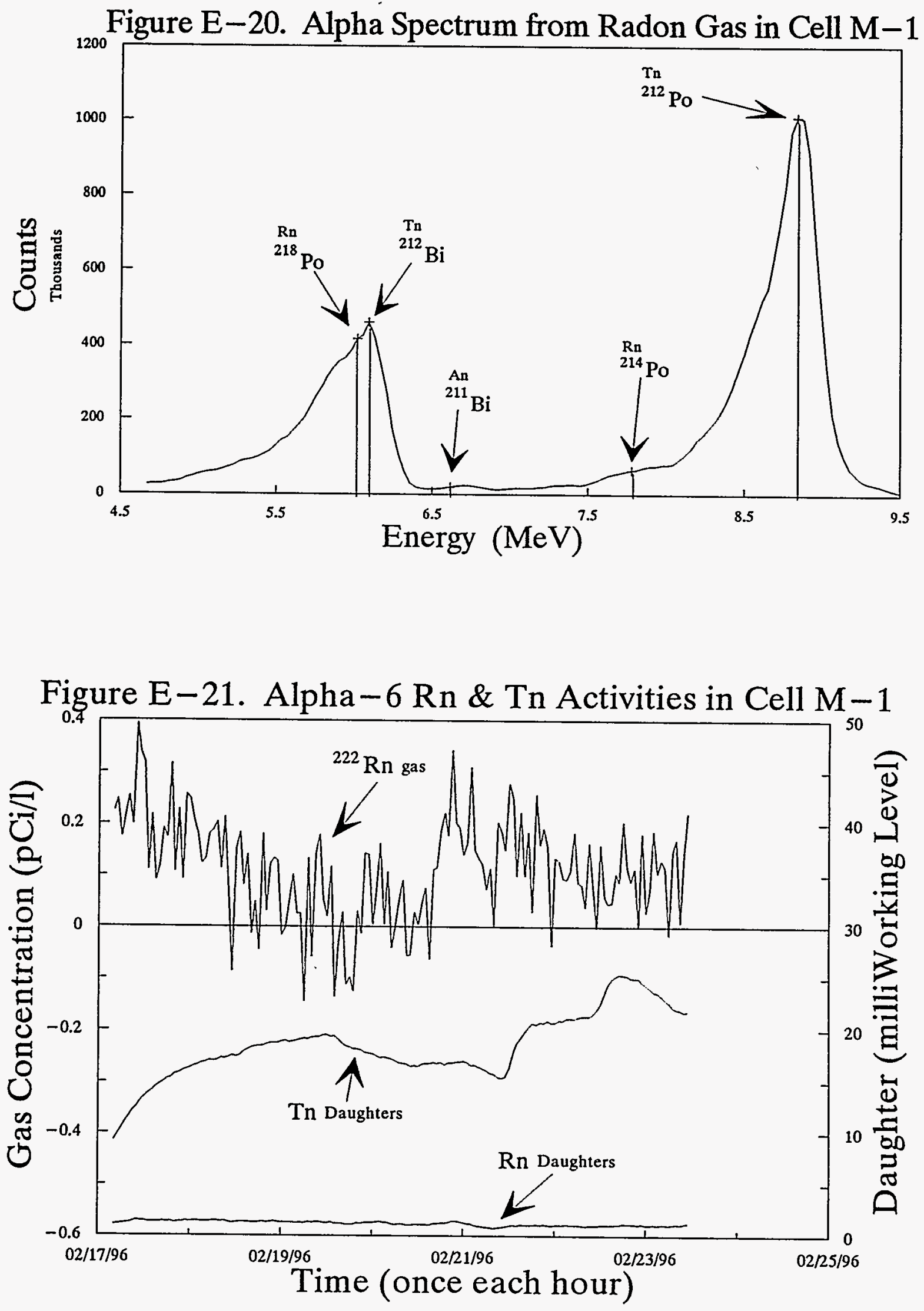
Figure $\mathrm{E}-22$. Cell $\mathrm{M}-1$ Discharge

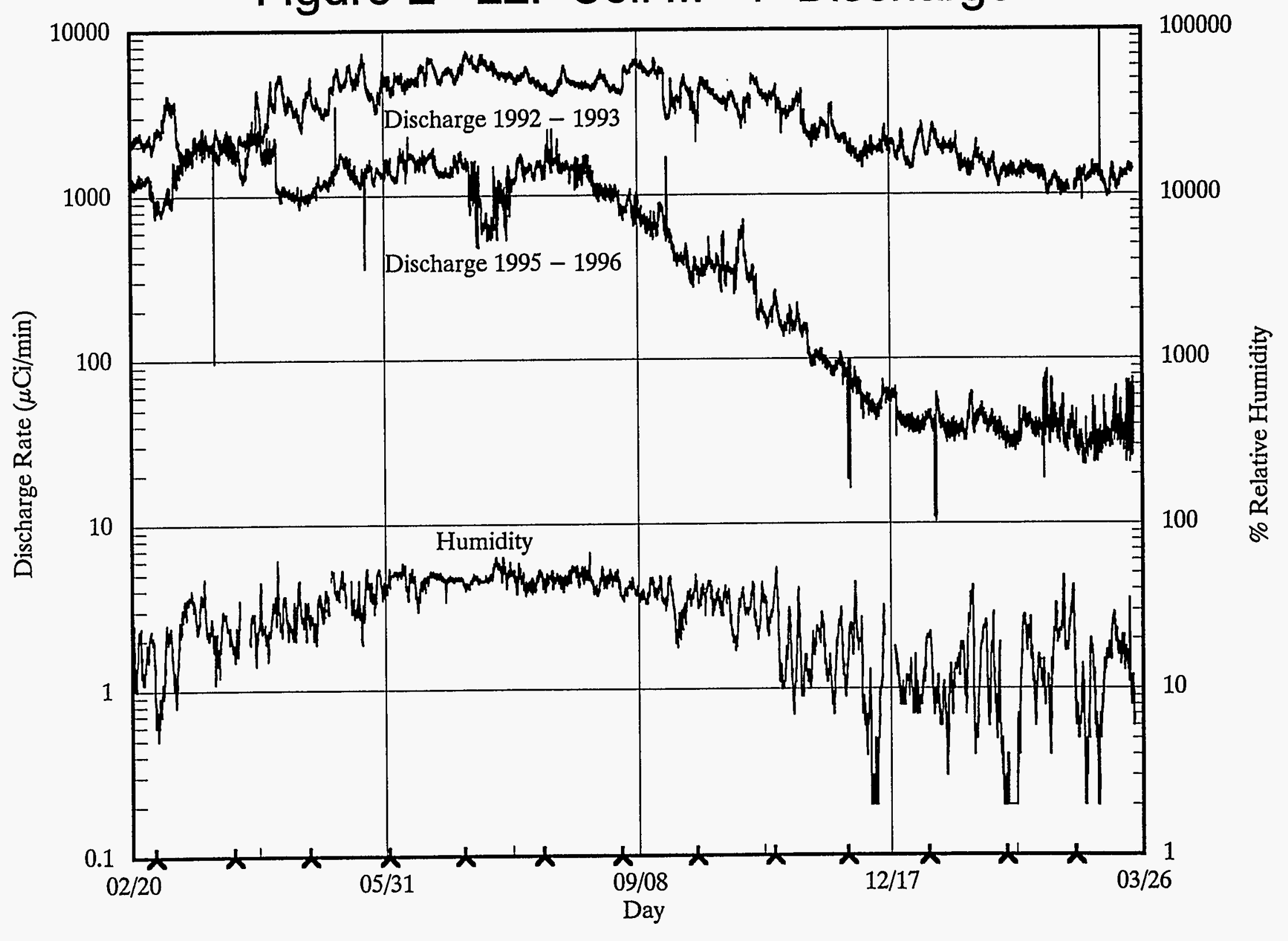


T. DiSanto (CMT)

J. W. Emery (CMT)

L. D. Hafenrichter (CMT)

J. C. Hoh (CMT)

M. Surchik (CMT)

T. T. Anderson (RE)

R. H. Gebner (RE)

A. E. Wright (RE)

D. M. Nelson (ESH-DA)

T. Branch (HP)

N. L. Contos (HP)

J. Erick (HP)

D. C. Geraghty (HP)

M. E. Hayes (HP)

A. L. Keebler (HP)

F. P. Marchetti (HP)

M. R. O'Connor (HP)

D. W. Reilly (HP)

M. J. Robinet (HP)

C. M. Sholeen (HP)

M. A. Sreniawski (HP)

R. Walker (HP)

HP Office - 20

C. Grandy (EWM)

J. Johnson (EWM)

W. D. Ray (EWM)

D. C. Pancake (EWM)

S. L. Santarelli (EWM)

M. A. Sodaro (EWM)
J. V. Beitz (CHM)

F. A. Cafasso (CHM) - 3

E. P. Horwitz (CHM)

L. R. Morss (CHM)

F. J. Schmitz (CHM)

V. K. Steed (CHM)

A. C. Youngs (CHM)

H. I. Avci (EA)

C. L. Cheever (TD)

R. W. Rose (TD) - 6

R. W. Fergus (ECT)

J. E. Miranda, Jr (ECT) 
